\title{
Calcium Enhanced Protein Recovery from Underutilized Aquatic Resources and Optimizing Protein Gelation Strategies Using Functional Ingredients
}

Ilgin Paker

Follow this and additional works at: https://researchrepository.wvu.edu/etd

\footnotetext{
Recommended Citation

Paker, Ilgin, "Calcium Enhanced Protein Recovery from Underutilized Aquatic Resources and Optimizing Protein Gelation Strategies Using Functional Ingredients" (2015). Graduate Theses, Dissertations, and Problem Reports. 6370.

https://researchrepository.wvu.edu/etd/6370

This Dissertation is protected by copyright and/or related rights. It has been brought to you by the The Research Repository @ WVU with permission from the rights-holder(s). You are free to use this Dissertation in any way that is permitted by the copyright and related rights legislation that applies to your use. For other uses you must obtain permission from the rights-holder(s) directly, unless additional rights are indicated by a Creative Commons license in the record and/ or on the work itself. This Dissertation has been accepted for inclusion in WVU Graduate Theses, Dissertations, and Problem Reports collection by an authorized administrator of The Research Repository @ WVU. For more information, please contact researchrepository@mail.wvu.edu.
} 


\title{
Calcium Enhanced Protein Recovery from Underutilized Aquatic
}

\section{Resources and Optimizing Protein Gelation Strategies Using}

\section{Functional Ingredients}

\author{
ILGIN PAKER \\ Dissertation submitted to the \\ Davis College of Agriculture, Natural Resources and Design \\ at West Virginia University \\ in partial fulfillment of the requirements \\ for the degree of \\ Doctor of Philosophy \\ in \\ Animal and Food Science \\ Kristen E. Matak, Ph.D., Chair \\ Jacek Jaczynski, Ph.D., \\ Janet C. Tou, Ph.D., \\ Jianbo Yao, Ph.D., \\ Litha Sivanandan, Ph.D.
}

\section{Division of Animal and Nutritional Sciences \\ Morgantown, West Virginia \\ 2015}

Keywords: Protein recovery, Sarcoplasmic Protein, Calcium hydroxide, Protein Gel 


\title{
ABSTRACT \\ Calcium Enhanced Protein Recovery from Underutilized Aquatic Resources and
}

\author{
Optimizing Protein Gelation Strategies Using Functional Ingredients
}

\section{Ilgin Paker}

Utilization of aquatic resources has rapidly gained importance. Traditional fish processing does not utilize the majority of the fish, thus generating large quantities of waste that impacts the economy, sustainability and environmental stress adversely. Protein can be extracted from underutilized sources such as silver carp and catfish using a $\mathrm{pH}$ shift processing method and incorporated into the human diet. Therefore, myofibrillar proteins were extracted from ground fish using different alkali solubilization and precipitation strategies. The efficacy of protein separation from lipids, and insoluble such as skin, fins, scales and bones were investigated and compared. Protein and lipid recovery yields were calculated to determine the economic feasibility of the procedure by calculating the amount of material recovered out of the available protein or lipids present in the initial material. Mineral content of the recovered protein was analyzed and compared to the initial fish and Alaska Pollock surimi.

Although every factor such as solubilization $\mathrm{pH}$, base, and acid as well as their interactions had a significant effect on the results, effect of processing base was more evident for protein separation. Protein solubility was significantly increased $(\mathrm{p}<0.05)$ when calcium hydroxide $\left(\mathrm{Ca}(\mathrm{OH})_{2}\right)$ was used compared to sodium hydroxide $(\mathrm{NaOH})$. Therefore, protein concentration was also greater $(\mathrm{p}<0.05)$ with lower amount of impurities such as lipids and ash when $\mathrm{Ca}(\mathrm{OH})_{2}$ was used as the processing base compared to $\mathrm{NaOH}$ at every solubilization $\mathrm{pH}(11.0,11.5,12.0,12.3)$ tested in this study. Overall, protein was concentrated at a range of 88-92 g/100g and 64-87 g/100g when $\mathrm{Ca}(\mathrm{OH})_{2}$ and $\mathrm{NaOH}$ were used during solubilization, respectively. Contrary to protein concentration, overall recovered lipid concentration ranged between 70-100 g/100g did not differ between processing bases. Protein recovery yields were also similar between processing acids and bases, ranging between $42-59 \mathrm{~g} / 100 \mathrm{~g}$. $\mathrm{Ca}(\mathrm{OH})_{2}$ and organic acids (lactic and acetic acid) were as effective as the traditionally used $\mathrm{NaOH}$ and hydrochloric acid in protein recovery using $\mathrm{pH}$ shifts. The mineral content of the recovered proteins, on the other hand, differed greatly between solubilization and precipitation strategies applied. Using $\mathrm{Ca}(\mathrm{OH})_{2}$ for protein solubilization resulted in a protein fraction with increased calcium content and reduced sodium amount compared to $\mathrm{NaOH}$ processing.

The recovered protein was then made into protein gels in order to investigate gelation conditions. Fish muscle protein mainly consisting of myosin and actin cross-link and form a gel network upon heating. Yet, the efficiency of gel setting period that allows for the crosslinking to take place depends on a variety of factors mainly impacted by time and temperature. Protein gel texture and color is also affected by post cooking storage. Therefore, widely applied pre-cooking gelation time and temperature strategies, and post-cooking period on texture and color of final protein gels was investigated. Four most commonly applied pre-cooking gelation strategies (nosetting time, $30 \mathrm{~min}$ at $25^{\circ} \mathrm{C}, 1 \mathrm{~h}$ at $40^{\circ} \mathrm{C}$, or $24 \mathrm{~h}$ at $4^{\circ} \mathrm{C}$ ) were applied to protein pastes (fish protein concentrate and standard functional additives). After cooking, texture and color were either 
analyzed directly or after $24 \mathrm{~h}$ at $4^{\circ} \mathrm{C}$ on gels adjusted to room temperature. Gels that were immediately cooked and analyzed were harder, gummier, and chewier $(\mathrm{p}<0.05)$; however, gel chewiness, cohesiveness and firmness increased when gels were allowed to set for $24 \mathrm{~h}$ at $4{ }^{\circ} \mathrm{C}$ and stored before cooking. Therefore a more uniform network formation may be achieved when gels are allowed to set at lower temperatures for a longer period of time; however, the prolonged gel setting time followed by post cooking storage decreased whiteness of gels. A gel storage period post cooking improved gel stability.

Gelation properties as well as protein amount in the recovered protein gels can be changed by salvaging water soluble sarcoplasmic proteins from fish processing water or solution and incorporating them into myofibrillar protein gels. Therefore, sarcoplasmic proteins of silver carp were solubilized and added back to recovered myofibrillar protein or Alaska Pollock in solution form to investigate the impact on texture and color of protein gels. Sarcoplasmic protein amounts tested (77 or $144 \mathrm{mg} / \mathrm{kg}$ paste) yielded softer, less gummy, chewy, cohesive and resilient ( $\mathrm{p}<0.05)$ gels compared gels containing transglutaminase, an exogenous enzyme. In order to investigate the effects of greater amounts of sarcoplasmic proteins in the myofibrillar protein gels, solubilized sarcoplasmic proteins were concentrated, made into a powder using a freeze-dryer and added back into recovered protein gels. Protein gels were developed from either $\mathrm{NaOH}$ or $\mathrm{Ca}(\mathrm{OH})_{2}$ processed catfish myofibrillar protein with or without transglutaminase, functional additives and sarcoplasmic protein powder. The effect of sarcoplasmic protein addition differed according to the processing base used to recover myofibrillar protein. When myofibrillar protein was solubilized using $\mathrm{NaOH}$, due to the possible denaturation induced by high salt conditions, sarcoplasmic protein containing gels $(10$ or $23 \mathrm{~g} / \mathrm{kg})$ were softer, less gummy, chewy, firm, and cohesive $(\mathrm{p}<0.05)$ compared to gels developed with $5 \mathrm{~g}$ transglutaminase/kg paste. On the other hand, $\mathrm{Ca}(\mathrm{OH})_{2}$ processed protein gels containing $23 \mathrm{~g} / \mathrm{kg}$ paste sarcoplasmic protein and no other functional additive like starch, transglutaminase or polyphosphates similar textural properties (hardness, springiness, cohesiveness, gumminess, chewiness, resilience, firmness, and resistance to deformation) as gels made with $5 \mathrm{~g}$ transglutaminase/ $\mathrm{kg}$ paste along with other functional additives (starch and polyphosphates).

A separate study investigating the effects of starch addition at increasing amounts $(0,5,10$, $15,20 \mathrm{~g} / \mathrm{kg}$ paste) determined that most of the textural attributes such as hardness, gumminess, chewiness, firmness and resistance to deformation were higher $(\mathrm{p}<0.05)$ for gels containing starch; however, these attributes did not increase with the increasing starch concentration. Therefore, the similar textural properties observed in $23 \mathrm{~g} / \mathrm{kg}$ paste sarcoplasmic protein containing gels without starch or polyphosphates and gels developed using 5 transglutaminase $/ \mathrm{kg}$ paste, $15 \mathrm{~g}$ starch/ $\mathrm{kg}$ paste and $3 \mathrm{~g}$ polyphosphates/kg paste can be attributed to the gel strengthening properties of high amounts of sarcoplasmic proteins in calcium enhanced myofibrillar protein gels. Comparison between gels recovered by either $\mathrm{NaOH}$ or $\mathrm{Ca}(\mathrm{OH})_{2}$ showed that calcium enhanced protein gels were harder, gummier, chewier, and whiter $(\mathrm{p}<0.05)$ then gels made with $\mathrm{NaOH}$ recovered myofibrillar protein. Therefore, myofibrillar protein recovery using $\mathrm{Ca}(\mathrm{OH})_{2}$ may increase the rate of gel network formation by triggering calcium dependent endogenous TGase activity. Moreover, sarcoplasmic protein may bind to myofibrillar protein and form a firmer gel in low salt containing environments. 
Overall, this research shows that $\mathrm{Ca}(\mathrm{OH})_{2}$ is effective in protein solubility and separates proteins from other fractions such as lipids and insolubles when used as a processing base during pH shifts. $\mathrm{Ca}(\mathrm{OH})_{2}$ solubilization yields a recovered protein fraction enhanced with calcium, and lowered sodium. Therefore, protein recovered using $\mathrm{Ca}(\mathrm{OH})_{2}$ will yield a naturally whiter end product with a more beneficial content. Protein gels made from calcium enhanced protein will be harder and naturally whiter. Moreover, sarcoplasmic protein recovered using simple solubilization steps from fish and by-products may be used as a nutritional supplement to enhance protein content of food products or can be incorporated into functional food products such as protein gels containing lower amounts of sodium. 


\section{ACKNOWLEDGEMENTS}

This work was made possible by the HATCH Program Project \# (WVA 00622).

I would like to extend my deepest gratitude and appreciation to my advisor, Dr. Kristen E. Matak. She has been inspirational and encouraging throughout my Master's and $\mathrm{PhD}$ work. Without her guidance and thorough edits this dissertation would not be possible.

I am grateful to my committee members; Dr. Jacek Jaczynski, Dr. Janet Tou, Dr. Jianbo Yao, and Dr. Litha Sivanandan for their support, genuine care, and guidance. Their intellect, experience and friendship will be deeply missed. It was an honor to have worked with such a motivational committee.

My friends and colleagues, Sarah Beamer and Karina Walker, thank you for supporting and helping me in any way that you could.

My sincere gratitude is extended to the faculty and staff of the Division of Animal and Nutritional Sciences for their continued aid, guidance, and for the opportunities they provided to make this research possible.

Thank you, Dr.Semmens for donating the black bullhead catfish, and Dr. Kenney for letting me use the meats laboratory and equipment for vacuum packaging the fish. Susan Slider and Tammy Webster, I am grateful for your help and technical expertise in completing my analyses. Karen Martin, I appreciate your assistance with the optical microscope.

Finally, I want to thank my family. My son, Alp, for the massive love he created; Alper, my dear husband, for always challenging and supporting me; My parents, Nurdan and Tufan Paker, for their unconditional love and support; and finally my grandparents, Turkan and Kemal Tanyeri, thank you for making me the person I am. I have received so much love and support from every single one of you, I could not be happier. 


\section{TABLE OF CONTENTS}

LIST OF TABLES

viii

LIST OF FIGURES $\mathbf{X}$

INTRODUCTION 1

LITERATURE REVIEW 6

CHAPTER 1 26

1.1.Abstract 26

1.2.Introduction

1.3.Materials and methods

28

1.4.Results and discussion

34

1.5. Tables and figures

CHAPTER 2 57

1.1.Abstract

1.2.Introduction

1.3. Materials and methods

61

1.4.Results and discussion

66

1.5. Tables and figures

80

CHAPTER 3

88

1.1.Abstract

1.2.Introduction

1.3.Materials and methods

90

1.4.Results and discussion

95

1.5. Tables and figures

107

CHAPTER 4

112

1.1.Abstract

112

1.2.Introduction

113 
1.3.Materials and methods $\quad 114$

1.4.Results and discussion $\quad 120$

$\begin{array}{ll}\text { 1.5. Tables and figures } & 130\end{array}$

\begin{tabular}{lr} 
CHAPTER 5 & 135 \\
\hline
\end{tabular}

1.1.Abstract $\quad 135$

1.2.Introduction $\quad 136$

1.3.Materials and methods 137

1.4.Results and discussion $\quad 142$

1.5. Tables and figures $\quad 152$

CHAPTER 6 159

1.1.Abstract 159

1.2.Introduction $\quad 160$

1.3.Materials and methods 161

1.4.Results and discussion $\quad 166$

$\begin{array}{ll}\text { 1.5. Tables and figures } & 178\end{array}$

\begin{tabular}{lr} 
CHAPTER 7 & 183 \\
\hline
\end{tabular}

1.1.Abstract $\quad 183$

1.2.Introduction $\quad 184$

1.3.Materials and methods $\quad 186$

1.4.Results and discussion $\quad 192$

$\begin{array}{ll}\text { 1.5. Tables and figures } & 204\end{array}$

CONCLUSIONS \& INDUSTRY IMPLICATIONS 209

\begin{tabular}{lr} 
APPENDIX & 211 \\
\hline
\end{tabular} 


\section{LIST OF TABLES}

\section{CHAPTER 1}

Table 1. Proximate composition ( $\mathrm{g} / 100 \mathrm{~g}$, dry basis) of the recovered protein and lipid fractions using different solubilization strategies and initial starting material (ground catfish). 54

Table 2. Mineral composition (Fe, $\mathrm{Mg}, \mathrm{Ca}, \mathrm{P}$, and $\mathrm{Na}$ ) of the recovered protein using different $\mathrm{pH}$ shift treatments.

Table 3. Mineral composition (Fe, $\mathrm{Mg}, \mathrm{Ca}, \mathrm{P}$, and $\mathrm{Na}$ ) of the recovered protein using different $\mathrm{pH}$ shift treatments, initial starting material (ground black bullhead catfish), and Alaska Pollock surimi.

\section{CHAPTER 2}

Table 1. Proximate composition of the recovered protein and lipid fractions using different solubilization strategies and initial starting material (ground catfish).

Table 2. Mineral composition (Iron (Fe), Magnesium (Mg), Calcium (Ca), Phosphorus (P), and Sodium $(\mathrm{Na})$ ) of the recovered protein using different $\mathrm{pH}$ shift treatments, initial starting material (ground catfish), and Alaska Pollock.

Table 3. Daily recommended levels of Protein, Iron (Fe), Magnesium (Mg), Calcium (Ca), and Phosphorus (P), and daily upper limit of Sodium (Na).

\section{CHAPTER 3}

Table 1. Color properties of recovered black catfish protein gels.

\section{CHAPTER 4}

Table 1. Description and amount of protein gel additives for different treatments.

Table 2. Color properties of protein gels made from recovered silver carp protein and Alaska Pollock surimi.

\section{CHAPTER 5}

Table 1. Differential scanning calorimetry (DSC) measurements (temperature onset (Tonset), maximum temperature (Tmax), and net enthalpy) of isoelectrically recovered black bullhead catfish protein pastes developed using different amounts of starch $(0,5,10,15,20 \mathrm{~g} / \mathrm{kg}$ protein paste). 
Table 2. Color properties of recovered black bullhead catfish protein gels containing different starch amounts $(0,5,10,15,20 \mathrm{~g} / \mathrm{kg}$ protein paste $)$.

\section{CHAPTER 6}

Table 1. Differential scanning calorimetry (DSC) measurements (temperature onset (Tonset), maximum temperature (Tmax), and net enthalpy) of isoelectrically recovered black bullhead catfish protein pastes developed using different additives.

Table 2. Hardness, Springiness, Cohesiveness, Gumminess, Chewiness and Resilience (texture profile analysis) of gels. Data are given as mean \pm standard deviation.

Table 3. Color properties and whiteness of recovered catfish protein gels

\section{CHAPTER 7}

Table 1. Differential scanning calorimetry (DSC) measurements (temperature onset (Tonset), maximum temperature (Tmax), and net enthalpy) of isoelectrically recovered black bullhead catfish protein pastes developed using different additives.

206

Table 2. Texture profile (Hardness, Springiness, Cohesiveness, Gumminess, Chewiness, Resilience) of protein gels.

Table 3. Color and whiteness of protein gels.

\section{APPENDIX}

Table 1. Proximate comporition (ash, lipid, protein) of recovered protein fractions using different $\mathrm{pH}$ shift processing strategies, on dry bases.

Table 2. Comparison of protein recovery yields extracted using different solubilization and precipitation strategies. 


\section{LIST OF FIGURES}

\section{CHAPTER 1}

Figure 1. Protein solubility percentages of different alkali solubilization strategies. 47

Figure 2. Protein concentration mean values separated by processing base to show the effect of $\begin{array}{ll}\text { solubilization } \mathrm{pH} . & 48\end{array}$

Figure 3. Lipid concentration mean values separated by processing base to show the effect of $\begin{array}{ll}\text { solubilization } \mathrm{pH} . & 49\end{array}$

Figure 4. Protein and lipid recovery yields of different solubilization strategies. $\quad 50$

Figure 5. Protein recovery yields of different solubilization strategies processed by different $\begin{array}{ll}\text { solubilization bases. } & 51\end{array}$

Figure 6. Lipid recovery yields of different solubilization strategies processed by different solubilization bases.

52

Figure 7. Mineral composition (Fe, $\mathrm{Mg}, \mathrm{Ca}, \mathrm{P}$, and $\mathrm{Na}$ ) of the calcium hydroxide solubilized protein using different $\mathrm{pH}$ values, initial starting material (ground catfish), and Alaska Pollock surimi.

\section{CHAPTER 2}

Figure 1. Protein and lipid recovery yields of different solubilization strategies.

Figure 2. Protein recovery yields obtained by using different precipitation strategies. 84

Figure 3. Dietary calcium turnover rate in healthy adults. $\quad 85$

Figure 4. Optical images of the freeze-dried recovered proteins using 86

Figure 5. Optical image of the freeze-dried, gutted, and ground black bullhead catfish. 87

\section{CHAPTER 3}

Figure 1. Differential scanning calorimetry thermograms of isoelectrically recovered catfish protein paste, Alaska Pollock surimi and initial ground catfish.

107

Figure 2. Hardness, Springiness, Cohesiveness, Gumminess, Chewiness and Resilience of recovered protein gels.

Figure 3. Kramer shear stress (kPa), Kramer shear force (g/g muscle), torsional shear stress (kPa) and torsional shear strain $(\mathrm{kPa})$ of recovered black catfish protein gels. 109

Figure 4. Whiteness of recovered black catfish protein gels. 


\section{CHAPTER 4}

Figure 1. Hardness, Springiness, Cohesiveness, Gumminess, Chewiness and Resilience (texture profile analysis) of gels.

Figure 2. Kramer Shear Force, Kramer Shear Stress $(\tau)$, Torsional Stress $(\mathrm{kPa})$ and Torsional

Strain $(\mathrm{kPa})$ of recovered silver carp protein and Alaska Pollock surimi gels.

Figure 3. Whiteness of silver carp protein and Alaska Pollock surimi gels.

\section{CHAPTER 5}

Figure 1. Differential scanning calorimetry (DSC) thermograms of black bullhead catfish protein pastes developed using different amounts of starch $(0,5,10,15,20 \mathrm{~g} / \mathrm{kg}$ protein paste $) .152$

Figure 2. Expressible water $(\mathrm{g} / 100 \mathrm{~g})$ content of protein pastes containing different amounts of starch $(0,5,10,15,20 \mathrm{~g} / \mathrm{kg}$ protein paste $)$.

Figure 3. Hardness, Springiness, Cohesiveness, Gumminess, Chewiness and Resilience (texture profile analysis) of gels containing different amounts of starch $(0,5,10,15,20 \mathrm{~g} / \mathrm{kg}$ protein paste).

154

Figure 4. Kramer shear stress, Kramer shear force, torsional shear stress and torsional shear strain of recovered black bullhead catfish protein gels containing different amounts of starch $(0,5,10,15,20 \mathrm{~g} / \mathrm{kg}$ protein paste) .

Figure 5. Whiteness of recovered black bullhead catfish protein gels containing different amounts of starch $(0,5,10,15,20 \mathrm{~g} / \mathrm{kg}$ protein paste).

\section{CHAPTER 6}

Figure 1. Differential scanning calorimetry thermograms of black bullhead catfish protein pastes developed using different additives.

Figure 2. Kramer shear stress, Kramer shear force, torsional shear stress and torsional shear strain of recovered black bullhead catfish protein gels.

\section{CHAPTER 7}

Figure 1. Differential scanning calorimetry thermograms of black bullhead catfish protein pastes developed using different additives. 
Figure 2. Kramer shear stress, Kramer shear force, torsional shear stress and torsional shear strain of recovered black bullhead catfish protein gels.

\section{APPENDIX}

Figure 1. Protein concentrations in the recovered protein fractions using different solubilization and precipitation strategies. 


\section{INTRODUCTION}

Fish muscle protein is highly soluble in highly positive charged or negative charged solutions where protein-protein interactions are minimized by increased repulsion forces and protein-water interactions are triggered ${ }^{1}$. Therefore, protein solubilization can readily be achieved by applying $\mathrm{pH}$ shifts followed by precipitation at the isoelectric point. The solubility of muscle protein may be achieved at either extremely low $(\mathrm{pH}$ 2.0-3.0) or extremely high $(\mathrm{pH}$ 10.5-12.5) $\mathrm{pH}$ values with the use of a processing acid or a base ${ }^{2}$. Alkaline solubization using a processing base to increase the $\mathrm{pH}$ of the fish and water mixture was shown to result in a similar protein recovery yield as acidic solubilization, while inducing less conformational changes in protein structure, myosin degradation ${ }^{3-6}$. Traditionally used processing base during $\mathrm{pH}$ shift processing, sodium hydroxide $(\mathrm{NaOH})$ yields a protein fraction with increased sodium content compared to both the initial starting material as well as the Alaska Pollock surimi which is considered as the industry standard ${ }^{3,7}$. Using another base such as calcium hydroxide $\left(\mathrm{Ca}(\mathrm{OH})_{2}\right)$ during alkali solubilization may increase protein concentration in the recovered protein fraction by effective removal of impurities such as lipids, skins, and bones while yielding a protein fraction with high calcium and low sodium content.

Along with that, protein and lipid recovery yields are important determinants of economic feasibility of the extraction method and may be increased by using different solubilization bases and precipitation acids. Protein recovery yield as well as the efficacy of removal of impurities from the protein fraction depends greatly on solubilization $\mathrm{pH}$, processing acids and bases, and their interactions. Recovery using $\mathrm{pH}$ shift processes range from 57-65 $\mathrm{g} / 100 \mathrm{~g}$ with the traditional surimi processing showing $58 \mathrm{~g} / 100 \mathrm{~g}$ protein recovery ${ }^{6,8}$. Therefore, four different alkali solubilization $\mathrm{pH}$ values $(11.0,11.5,12.0$, and 12.3) were tested using either 
$\mathrm{NaOH}$ or $\mathrm{Ca}(\mathrm{OH})_{2}$. Precipitation was achieved at the isoelectric point of protein, $\mathrm{pH} 5.5$, using either hydrochloric acid ( $\mathrm{HCl})$, lactic acid (LA), or acetic acid (AA) to determine the compositional (ash, lipid, protein) properties of the recovered protein and lipid fractions. Moreover, protein and lipid recovery yields were calculated, and the mineral content (iron, magnesium, calcium, phosphorus, and sodium) of the protein fractions were measured and compared.

The reason for testing the efficacy of organic acids was their association with curing, marinating, and preservation of meat and poultry products ${ }^{9-11}$. Along with their pathogen controlling properties, using different acids will yield different protein and mineral compositions in the recovered fraction ${ }^{3,12-15}$. An additional benefit of using organic acids during protein recovery is the less denaturation they induce in the native confirmation of protein compared to processing with strong acids such as $\mathrm{HCl}^{4,5}$. The conformational change induced in protein is important during further processing of the product.

Protein, once recovered, can be restructured into fish gels like surimi or incorporated into food products that are low in protein content. Therefore, gelation properties of recovered protein were investigated. Commonly used gel setting, and storage conditions were investigated to understand recovered protein gelation. The benefit of using $\mathrm{pH}$ shifts during protein recovery is the application of the protein extraction method to underutilized, hard to process fish, or fish processing by-products which is associated with reducing waste, and sustaining natural resources. Water soluble proteins, sarcoplasmic proteins, making up to $30 \mathrm{~g} / 100 \mathrm{~g}$ of fish are usually discarded during fish processing or surimi washing with the processing water ${ }^{16}$. Similarly, sarcoplasmic protein is lost in the $\mathrm{pH}$ shift processing water and discard with the supernatant. In an effort to utilize sarcoplasmic proteins as a protein source, sarcoplasmic protein 
was extracted from the initial ground fish used during $\mathrm{pH}$ shifts, and added back to the recovered protein. Protein gels were made using recovered protein with or without functional additives (transglutaminase, potato starch, and polyphosphates), and different amounts of sarcoplasmic protein. Thermal changes induced in protein groups (myosin, actin, and sarcoplasmic protein), and texture and color properties of protein gels were investigated.

The overall aim of this study was to determine a $\mathrm{pH}$ shift recovery strategy that increases the efficacy of protein separation from lipids, and insolubles such as skins, bones, and scales of the initial ground fish. The second objective was to recover protein with high amount of calcium and lower amount of sodium that displays a mineral content in accordance with the recommended daily intake guidelines. Utilizing natural resources more efficiently has been the building block of this study; therefore, incorporating sarcoplasmic protein into recovered protein to develop a protein product high in protein and calcium content was the last main objective of this study. 


\section{References}

1. Nolsøe, H.; Undeland, I. The acid and alkaline solubilization process for the isolation of muscle proteins: State of the art. Food Bioprocess Technol. 2009, 2, 1-27.

2. Gehring, C.K.; Gigliotti, J. C.; Moritz, J. S.; Tou, J. C.; Jaczynski, J. Functional and nutritional characteristics of proteins and lipids recovered by isoelectric processing of fish by-products and low-value fish: A review. Food Chem. 2011, 124, 422-431.

3. Paker, I.; Beamer, S.; Jaczynski, J.; Matak, K. E. Compositional characteristics of materials recovered from headed gutted silver carp (Hypophthalmichthys molitrix) by isoelectric solubilization and precipitation using organic acids. J. Food Sci. 2013, 78, E445-E451.

4. Paker, I.; Beamer, S.; Jaczynski, J.; Matak, K. E. The effect of organic acids on gelation characteristics of protein gels made from silver carp (Hypophthalmichthys molitrix) protein recovered by isoelectric solubilization and precipitation. LWT - Food Sci. Technol. 2013, 53, 3743.

5. Paker, I.; Beamer, S.; Jaczynski, J.; Matak, K. E. pH shift protein recovery with organic acids on texture and color of cooked gels. J Sci. Food Agr. 2015, 95, 275-280.

6. Marmon, S. K.; Undeland, I. Protein isolation from gutted herring (Clupea harengus) using pH-shift processes. J. Agric. Food Chem. 2010, 58, 10480-10486.

7. Taskaya, L.; Chen, Y.C.; Beamer, S.; Tou, J.C.; Jaczynski, J. Compositional Characteristics of Materials Recovered from Whole Gutted Silver Carp (Hypophthalmichthys molitrix) Using Isoelectrical Solubilization/ Precipitation. J. Agr. Food Chem. 2009, 57, 4259-4266.

8. Kristinsson, H. G.; Liang, Y. Effect of $\mathrm{pH}$-shift processing and surimi processing on Atlantic croaker (Micropogonias undulates) muscle proteins. J. Food Sci. 2006, 71, C304-C312.

9. De Wit, J. S.; Rombout, F. M. Antimicrobial activity of sodium lactate. Food Micro. 1990, 7, 113-120.

10. Knock, R. C.; Seyfert, M.; Hunt, M. C.; Dikeman, M. E.; Mancini, R. A.; Unruh, J.A.; Higgins, J. J.; Monderen, R. A Effects of potassium lactate, sodium chloride, sodium tripolyphosphate, and sodium acetate on colour, colour stability, and oxidative properties of injection-enhanced beef rib steaks. Meat Sci. 2006, 74, 312-318. 
11. Jensen, J. M.; Robbins, K. L.; Ryan, K. J.; Homco-Ryan, C.; McKeith, F. K.; Brewer, M. S. Effects of lactic and acetic acid salts on quality characteristics of enhanced pork during retail display. Meat Sci. 2003, 63, 501-508.

12. Otto, R.A.; Beamer, S.; Jaczynski, J.; Matak, K.E. The effect of using citric or acetic acid on survival of Listeria monocytogenes during fish protein recovery by isoelectric solubilization and precipitation process. J. Food Sci. 2011, 76, M579-583.

13. Otto, R.A.; Paker, I.; Bane, L.; Beamer, S.; Jaczynski, J.; Matak, K. E. 2011b. Survival of Listeria inocсиа in rainbow trout protein recovered by isoelectric solubilization and precipitation with acetic and citric acids. J. Food Prot. 2011, 74, 1348-1352.

14. Lansdowne, L.R.; Beamer, S.; Jaczynski, J.; Matak, K. E. Survival of Escherichia coli after isoelectric solubilization and precipitation of fish protein. J. Food Prot. 2009, 7, 1398-1403.

15. Lansdowne, L.R.; Beamer, S.; Jaczynski, J.; Matak, K. E. Survival of Listeria innocua after isoelectric solubilization and precipitation of fish protein. J. Food Sci. 2009, 74, M201-M205. 16. Miyaguchi, Y.; Nagayama, K.; Tsutsumi, M. Thermal and functional properties of porcine sarcoplasmic proteins: a comparison with some watersoluble animal proteins. Jpn. Soc. Animal Sci. 2000, 71(4), 416-424. 


\section{LITERATURE REVIEW}

\section{Protein Recovery Using Isoelectric Solubilization and Precipitation Method}

Isoelectric solubilization and precipitation (ISP) method is an efficient protein recovery technique for underutilized aquatic resources and fish processing by-products. A few simple steps involving grinding the initial material followed by dilution with distilled deionized water and addition of a processing acid or base to achieve an extremely low or high $\mathrm{pH}$ value will enable protein solubilization. Following centrifugation, insoluble components such as fish bones, scales, and skin as well as lipids are separated from the protein fraction. The aqueous protein solution is filtered and precipitated at the isoelectric point of the protein where a net charge of zero will lower electrostatic repulsion forces and allow for hydrophobic bond formation between protein molecules ${ }^{1}$. Protein will not precipitate if intermolecular hydrophobic bonds are not well developed due to hydration and steric repulsion forces ${ }^{1}$; therefore, protein concentration in the recovered protein fraction is an indicator for the efficacy of the solubilization step. The protein recovery yield is the amount of protein recovered from the available protein in the starting material. Recovery yields are greatly affected by the solubilization $\mathrm{pH}$, processing acid and base, the ionic strength of the solution, temperature and the amino acid composition of the initial material $^{2}$.

Reported protein concentrations in the protein fraction and protein recovery yields range from $32-95 \%$ and $50-79 \%$, respectively ${ }^{3-9}$. The wide gap in protein concentration is majorly due to the difference between protein solubilization strategies. For example, Taskaya et al. (2009) applied ISP to whole carp and reported crude protein concentrations of $89-90 \%$ and $94-95 \%$ when acidic ( $\mathrm{pH} 2.0$ and 3.0) and basic ( $\mathrm{pH} 11.5$ and 12.5) solubilization was performed using hydrochloric acid and sodium hydroxide $(\mathrm{NaOH})^{4}$. The same study reported protein recovery 
yields of 49, 42, 60 and $66 \%$ for whole gutted silver carp solubilized at $\mathrm{pH}$ 2.0, 3.0, 11.5 and 12.5 respectively ${ }^{10}$. A similar study using ISP to recover protein from headed, gutted silver carp also showed increased protein concentrations when acidic solubilization was applied at $\mathrm{pH} 2.5$, and 3.0 using either acetic acid (AA) and a 1:1 combination of 30\% formic and lactic acid (F\&L), 32-43\% and 20-52\% respectively; compared to alkali solubilization at $\mathrm{pH} 11.5$ and 12.0 using $\mathrm{NaOH}$, and precipitation was achieved using $\mathrm{AA}$ and $\mathrm{F} \& \mathrm{~L}, 77-82 \%$ and $51-80 \%{ }^{3}$. Protein recovery yields were higher when alkali solubilization was applied using $\mathrm{NaOH}$ as the processing base during ISP ${ }^{3}$. When AA was selected as the processing acid, a $71 \%$ recovery yield when was achieved and a $65 \%$ recovery yield was recorded when F\&L was chosen as the precipitating acid following alkali solubilization using $\mathrm{NaOH}^{3}$. Kristinsson and Ingadottir (2006) reported protein recovery yields between $61-68 \%$ for alkali-solubilization and $56-61 \%$ for acidic solubilization of tilapia muscle proteins ${ }^{7}$. The researchers concluded that there were no statistical differences between the two solubilization strategies ${ }^{7}$. On the other hand, another study conducted on Atlantic croaker using $\mathrm{NaOH}$ and $\mathrm{HCl}$ showed that acidic protein solubilization $(\mathrm{pH} 2.5)$ yielded higher protein recovery at $79 \%$ whereas alkali solubilization $(\mathrm{pH}$ 11.0) yielded $65 \%{ }^{11}$. Therefore, the main aim of this research was to determine if the protein concentration in the recovered protein fraction and protein recovery yield can be improved using different solubilization and precipitation strategies.

Along with improving protein concentration and protein recovery yields, another concern with ISP is the conformational changes induced on the proteins native structure. Although the majority of the changes in protein structure are reversible, some solubilization/precipitation strategies induce fewer conformational changes. In order to assess the conformational changes, researchers generally make the recovered protein into protein paste and use rheological 
measurements like elasticity and viscosity or run thermal analysis such as differential scanning calorimetry (DSC) to determine the thermal response of protein pastes. Moreover, spectroscopic studies, determination of protein groups following precipitation, hydrophobicity and sulfhydryl group analysis may also be performed to gain insight into the structural changes induced by processing of proteins. Kristinsson and Hultin (2003) investigated conformational changes in Atlantic cod protein following isoelectric extraction ${ }^{12}$. The muscle protein was solubilized either at $\mathrm{pH} 2.5$ or 11.0 and precipitated at $\mathrm{pH} 7.5$ and it was concluded that acidic solubilization led to higher protein dissociation and lower amount of exposed reactive thiol groups as well as binding sites ${ }^{12}$. It was also concluded by the researchers that both acidic and alkali solubilization induced certain changes in different sub-parts (head, tail, heavy and light chains) of myosin where acidic solubilization resulted in a less stable structure upon reassembly ${ }^{12}$. Moreover, the two different solubilization strategies induced different structural changes and resulted in completely different structures upon refolding ${ }^{12}$. Another study looking into the gelation and protein-protein binding properties of recovered tilapia muscle protein solubilized at $\mathrm{pH} 2.5,2.9,11.0$ or 11.2 using either $\mathrm{HCl}$ or $\mathrm{NaOH}$ reported that acidic solubilization yielded lower viscosity after thermal processing compared to alkali solubilized protein gels ${ }^{13}$. Silver carp protein was also solubilized using either acidic ( $\mathrm{pH} 2.5$ or 3.0) or basic ( $\mathrm{pH} 11.5$ and 12.0) $\mathrm{pH}$ values using $\mathrm{NaOH}, \mathrm{AA}$ or F\&L ${ }^{5}$. Overall, recovered protein gels showed similar viscoelastic and thermal properties as Alaska Pollock surimi which is considered as the industry standard for reconstructed aquatic products ${ }^{5}$. It is common to compare recovered protein to surimi products since surimi production only involves frequent wash cycles and no chemical processing. According to the research data, basic solubilization induced less conformational changes in recovered silver carp protein indicated by viscoelastic properties and torsional shear stress displayed by cooked gels ${ }^{5}$. On the other hand, it 
is also important to highlight that using different processing acids and bases yield different protein fractions by means of compositional, and structural properties.

The traditionally used base during $\mathrm{pH}$ shift protein recovery method is sodium hydroxide $(\mathrm{NaOH})$. Although an efficient protein solubilizing agent, protein solubilized using $\mathrm{NaOH}$ has increased sodium levels compared to the initial starting material (ground fish) as well as fish fillet as shown in a previously conducted study using silver carp ${ }^{3}$. High sodium content in foods is associated with the increased risk of hypertension and cardiovascular diseases and is undesirable ${ }^{3,14}$. Therefore, an alternative base may yield a protein fraction with less sodium in the recovered protein. A previously conducted study used potassium hydroxide $(\mathrm{KOH})$ as the processing base to reduce sodium content in the recovered protein fraction during ISP processing of striped bass ${ }^{15}$. Although the sodium amount was successfully reduced by replacing $\mathrm{NaOH}$ with $\mathrm{KOH}$, viscoelasticity of proteins recovered using $\mathrm{KOH}$ indicating functionality was less similar to surimi products compared to $\mathrm{NaOH}$ processed protein ${ }^{15}$.

Using $\mathrm{KOH}$ as the processing base during ISP increased potassium in the recovered protein ${ }^{15}$; therefore; another base such as calcium hydroxide $\left(\mathrm{Ca}(\mathrm{OH})_{2}\right)$ may increase calcium levels in the recovered protein. Calcium hydroxide is a widely used fortification agent in food products as well as a crisper or firming agent specifically in the pickling industry ${ }^{16,17}$. Benefits of using the generally recognized as safe $\mathrm{Ca}(\mathrm{OH})_{2}$ include reduced microbial activity, increased shelf life and nutritional value, and potential positive flavor changes ${ }^{18}$. Using $\mathrm{Ca}(\mathrm{OH})_{2}$ may therefore be preferable for product development after recovering protein by $\mathrm{pH}$ shifts. In addition, $\mathrm{Ca}(\mathrm{OH})_{2}$ is a divalent base, compared to the monovalent $\mathrm{NaOH}$, and may improve protein solubility during $\mathrm{pH}$ shift processing if the chemical reactions follow Hofmeister series ${ }^{19}$ leading to increased protein concentrations and recovery yields. 
While processing base type and solubilization $\mathrm{pH}$ have a major impact on protein solubility, the chemical interactions that take place during protein precipitation are more complex. Among many factors affecting precipitation, the role of chemicals and their dissociation or association constants, ionic radii, valence electrons, and the polarity of the ions following dissociation can be listed as the significant variables in similarly designed $\mathrm{pH}$ shift processing studies ${ }^{2}$. During alkali isoelectric solubilization, a base is used to negatively charge the protein molecules in order to reduce protein-protein interactions; on the other hand, during acidic solubilization, an acid yielding $\mathrm{H}$ into the solution is used to positively charge protein molecules. The negatively or positively charged protein molecules that became water soluble, is freed of charge by adjusting the $\mathrm{pH}$ of the solution to the isoelectric point of protein ${ }^{2}$. At this point, due to the increased hydrophobic interactions, protein precipitates ${ }^{2}$. Therefore, the chemicals involved in the solubilization and precipitation reactions determine the ionic strength, and volume of acid or base needed to precipitate protein. Lower amount of solute increases protein solubility; however, super-saturation is required for precipitation of proteins ${ }^{20}$.

Traditionally used hydrochloric acid $(\mathrm{HCl})$ in $\mathrm{pH}$ shift processing method may be tested against weaker acids having lower dissociation constants to determine the differences between protein concentrations and the recovery yields. Lower dissociation constants indicate lower rate of protonation. Protonation is the losing of hydrogen $(\mathrm{H})$ into the solution. Similarly, for bases, dissociation constants or ionic yields differ. For example, monovalent bases like $\mathrm{NaOH}$ will yield $1 \mathrm{~mol}$ of $\mathrm{Na}^{+}$per $1 \mathrm{~mol}$ of $\mathrm{OH}^{-}$; on the other hand, divalent bases like $\mathrm{Ca}(\mathrm{OH})_{2}$ will dissociate into $1 \mathrm{~mol}$ of $\mathrm{Ca}^{2+}$ per 2 mols of $\mathrm{OH}^{-}$. This will affect the volume of necessary chemical to increase or neutralize charges on protein molecules. Moreover, salting in and salting out of proteins will also be influenced by the different chemicals. 
Ionic strength and dissociation constants of chemicals also have an impact on protein denaturation. According to Paredi, Tomas, Crupkin, and Afion (1994) who investigated the thermal changes in Molina myofibrillar protein using differential scanning calorimetry, fish muscle denaturation increased with increasing ionic strength ${ }^{21}$. Moreover, thermal stability was shown to decrease as $\mathrm{pH}$ and ionic strength increased ${ }^{21}$. Therefore, stronger acids like $\mathrm{HCl}$ may denature protein to a greater extent compared to organic acids due to the rapid precipitation that occurs when using $\mathrm{HCl}$. The fast precipitation and unstable aggregate formation may be due to not providing enough time for protein molecules to form intermolecular disulphide bonds. This is why using organic acids that have lower dissociation constants compared to the strong acids may have the benefit of reducing protein denaturation.

Another advantage of selecting organic acids as processing chemicals during ISP is ensuring microbial safety ${ }^{22,23}$. Otto, et al. (2011a,b) investigated the antimicrobial effects of using citric and acetic acids on survival of Listeria monocytogenes, and Listeria innocua when inoculated in rainbow trout ${ }^{22,23}$. A $6.4 \log \mathrm{CFU} / \mathrm{g}$ protein L. innocua reduction was accomplished when solubilization took place at $\mathrm{pH} 3.0$ during ISP using acetic acid ${ }^{23}$. Efficacy of organic acids in reducing bacterial population compared to $\mathrm{HCl}$ was attributed to their ability of accumulating in the bacterial cell and inhibiting cellular activity ${ }^{23}$.

\section{Functional and Textural Properties of Recovered Protein}

Following recovery of protein, protein gels may be prepared to test and compare thermal denaturation, textural and color properties between different protein recovery strategies. Furthermore, recovered protein gels may be compared with Alaska Pollock surimi gels to determine the structural differences between processing methods as well as fish species. The recovered protein mainly consists of fish muscle or myofibrillar protein where myosin and actin 
are the major groups responsible for gel formation ${ }^{2}$. Sarcoplasmic protein makes up to $30 \%$ of fish protein is a water soluble protein mainly consisting of enzymes and hemoglobin ${ }^{24-27}$. Previously conducted research on whether or not sarcoplasmic protein interferes with myofibrillar protein gelation is inconclusive. Some researchers are keen on separation of sarcoplasmic protein from fish flesh whereas other have found sarcoplasmic protein to enhanced gel strength ${ }^{28-31}$. For example, Macfarlane, Schmidt, and Turner (1977) assessed binding properties of myosin, actomyosin and sarcoplasmic protein and concluded that sarcoplasmic protein displayed poor cohesiveness. Therefore, similar to conclusions drawn by Okada (1964), sarcoplasmic proteins were stated to lower binding proteins and weaken protein gels ${ }^{28,29}$. On the other hand, more recent studies highlight the positive impact of adding sarcoplasmic protein into myofibrillar protein gels. Siriangkanakun and Yongsawatdigul (2012) found that trypsin, an enzyme that is responsible for protein degredation, was inhibited by sarcoplasmic protein extracted from common carp. Moreover, incorporation of $0.18 \%$ common carp sarcoplasmic protein that was in supernatant form into threadfin bream surimi increased breaking force of gels in a range of $58.8-104.9 \%$, and deformation from $18.6 \%$ up to $36.2 \%{ }^{30}$. Jafarpour and Gorczyca (2008) also showed increased breaking force, breaking distance, and gel strength with the addition of 35\% freeze-dried common carp sarcoplasmic protein powder into thawed threadfin bream surimi ${ }^{31}$. Another study by Hemung and Chin (2013) used the combination of sarcoplasmic protein powder $(0,0.1,0.5$, or $1 \%)$ and microbial transglutaminase $(0.5 \%)$ to investigate the effects on red sea bream myofibrillar protein gelation ${ }^{32}$. It was determined that shear stress and gel strength decreased as the sarcoplasmic protein powder concentration increased; whereas, cooking loss was decreased with the increasing sarcoplasmic protein powder incorporation ${ }^{32}$. Moreover, high thermal stability was observed when sarcoplasmic protein 
powder was added at $1 \%$. Therefore, sarcoplasmic protein addition into myofibrillar protein may help stabilize myofibrillar protein and lower cooking loss of gels ${ }^{32}$.

In addition to the effect of removal or incorporation of sarcoplasmic protein into myofibrillar protein gels, another possible concern is the influence of calcium entrapped in the recovered protein fraction due to processing with calcium hydroxide which may interfere with gel network formation. Speroni, Jung and De Lamballerie (2010) investigated the effects of calcium treatment on thermally induced soybean protein gelation ${ }^{33}$. The soybean isolates, extracted using ISP were enriched with calcium using 2 and $20 \mathrm{mM} \mathrm{CaCl}_{2}$ when the protein concentration was $8 \%$, and 2.5 and $25 \mathrm{mM} \mathrm{CaCl}_{2}$ was used for $10 \%$ protein dispersions ${ }^{33}$. Higher concentrations of $\mathrm{CaCl}_{2}$ treatment delayed thermal peaks indicated by DSC results, and significantly increased denaturation temperatures of $\beta$-conglycinin and glycinin, the two major protein groups found in soybean ${ }^{33}$. Moreover, gels were stiffer in the presence of calcium possibly due to the coagulation of glycinin and $\beta$-conglycinin, and the crosslinking of glycinin and calcium ${ }^{33}$. It was also explained that calcium may trigger association between protein molecules during heating, and increase hydrophobic interactions as well as form calcium bridges 34. Scilingo and Anon (2004) determined that addition of 1.23-5.0 mg calcium/g soybean protein triggered $\alpha, \alpha^{\prime}$ 'soluble aggregates whereas higher calcium amounts $(5.0-9.73 \mathrm{mg} / \mathrm{g}$ protein) enabled selective glycinin insolubilization. Overall, calcium incorporation into soybean protein isolates stabilized thermally induced gels and increased denaturation energy required to uncoil proteins, and reduced surface hydrophobicity ${ }^{34}$. Calcium induced protein aggregates were shown to be stabilized by hydrophobic interactions; therefore, contributing to gel stiffness ${ }^{33}$. This was also seen in previously conducted research where addition of calcium $(5-20 \mathrm{mM})$ in the form of $\mathrm{CaCl}_{2}$ increased hardness of whey protein gels formed at alkali $\mathrm{pH}$ values ${ }^{35}$. 
When the effect of sodium and calcium were compared, lower amounts (25-30 mM NaCl or $7.5 \mathrm{mM} \mathrm{CaCl}_{2}$ ) of either ion resulted in thin and translucent gels ${ }^{36}$. Addition of $50-75 \mathrm{mM}$ $\mathrm{NaCl}$ increased shear stress of whey protein gels whereas, a similar increase was observed with only $20 \mathrm{mM} \mathrm{CaCl}_{2}{ }^{36}$. Likewise, increasing calcium levels from 10 to $360 \mathrm{mM} / \mathrm{L}$ improved gel network formation in whey protein gels indicated by the increase in size and thickness of gel strands ${ }^{37}$. Moreover, adding $\mathrm{CaCl}_{2}$ also increased shear strain of gels; however, $\mathrm{NaCl}$ incorporation showed a decrease in gel strain ${ }^{36}$. Incorporation of up to $180 \mathrm{mM} / \mathrm{L} \mathrm{CaCl} 2$ increased shear stress at fracture; however, higher levels of $\mathrm{CaCl}_{2}$ ( $\operatorname{such}$ as $360 \mathrm{mM} / \mathrm{L}$ ) incorporation did not increase stress results any further ${ }^{37}$. Moreover, shear strain and water holding capacity decreased as calcium levels increased ${ }^{37}$.

Protein gel properties depend on variables such as incubation time and temperature, storage conditions, and the fish species or the protein source as well as ionic content and concentration. A study by Ramirez et al. (2003) investigated the effects of $\mathrm{CaCl}_{2}$ concentration $(0-0.4 \%)$, and incubation time $(30-90 \mathrm{~min})$ and temperature $\left(25-45^{\circ} \mathrm{C}\right)$ on the gel properties of striped mullet protein gels ${ }^{38}$. It was seen that calcium content was the major factor affecting shear stress of gels and optimum gelation conditions indicated by shear stress and strain were determined as $0.4 \%$ calcium content, where gels were incubated at $39.3{ }^{\circ} \mathrm{C}$ for $1 \mathrm{~h}^{38}$. On the other hand, Benjakul, Chantarasuwan, and Visessanguan (2003) determined that tropical fish species like threadfin bream, bigeye snapper, barracuda and bigeye croaker protein gels benefited from incubation at $25^{\circ} \mathrm{C}$ for a prolonged time $(8 \mathrm{~h})$ indicated by increased breaking force and deformation ${ }^{39}$. Non-disulfide bonds, polymerization and lower amount of heavy chain myosin due to denaturation were highlighted as the reasons for stronger gel formation ${ }^{40}$. 
Alvarez, Couso, and Tejada Yabar (1995) determined that sardine surimi gels benefited from a gel setting time for $30-60 \mathrm{~min}$ at $35^{\circ} \mathrm{C}$ indicated by increased gel strength ${ }^{41}$. Moreover, it was determined that an incubation period was necessary for acceptable gel formation and for protein stability during heating ${ }^{41}$. Another similar study investigating the effects of Pacific whiting protein gelation properties stated that gel setting at $25^{\circ} \mathrm{C}$ yielded the strongest gels ${ }^{42}$. Luo et al. (2004) looked at gel setting conditions of different grade Alaska Pollock and common carp surimi when soy protein isolate was incorporated into the surimi at increasing concentrations $(0,10,20,30 \text {, and } 40 \%)^{43}$. Breaking force and breaking distance decreased as the concentration of soy protein isolate increased in the surimi gels for all tested samples ${ }^{43}$.

Moreover, the highest breaking force and distance was observed when surimi gels were allowed to set for $60 \mathrm{~min}$ at $30^{\circ} \mathrm{C}$, and the lowest results were obtained when the gels were incubated at $50^{\circ} \mathrm{C}$ for $60 \mathrm{~min}^{43}$. Different grades of surimi responded differently to gel setting conditions of either directly cooking (no gel setting period) or incubation at $40{ }^{\circ} \mathrm{C}$ for 60 min prior to cooking ${ }^{43}$. For example, direct cooking with no incubation period was more beneficial for low grade Alaska Pollock surimi gels compared to high grade Alaska Pollock surimi gels which benefited more from gel setting at $40^{\circ} \mathrm{C}$ for 60 min compared to no set gels as indicated by higher breaking force and distance ${ }^{43}$. Common carp surimi gels, on the other hand, did not show significant differences $(p>0.05)$ in breaking force or distance between gel setting conditions ${ }^{43}$. Gel color being another important aspect of product marketability and consumer acceptance was also assessed ${ }^{43}$. Lightness and whiteness of surimi gels decreased as the soy protein isolate amount increased, on the other hand, gel setting conditions did not influence gel color ${ }^{43}$.

Luo et al. (2001) compared gel strength of common carp, grass carp, and silver carp surimi to Alaska Pollock surimi which is considered the industry standard and a high grade 
protein source ${ }^{44}$. They found that Alaska Pollok surimi gels were superior to the latter indicated by breaking force of samples, and different fish species as the protein source benefited from different gel setting conditions ${ }^{44}$. For example, incubating Alaska Pollock at $35^{\circ} \mathrm{C}$ for $30 \mathrm{~min}$, common carp at $35^{\circ} \mathrm{C}$ for $120 \mathrm{~min}$, grass carp at $40{ }^{\circ} \mathrm{C}$ for $30 \mathrm{~min}$, and silver carp at $35^{\circ} \mathrm{C}$ for 60 min yielded highest breaking force ${ }^{44}$. Moreover, gel setting period increased breaking force of all surimi gels compared to gels with no incubation period ${ }^{44}$.

Gel formation is also affected by the concentration of gel enhancers such as exogenous transglutaminase (TGase), potato starch, polyphosphates and salt. TGase (glutaminyl peptide:amine $\gamma$-glutamyltransferase, E.C. 2.3.2.13) is an enzyme that is widely found in animal and fish tissues ${ }^{45}$. TGase is also isolated from Streptoverticillium $s p$. and is a commercially available to be used in food products with the benefit of functioning without the need of additional calcium ions ${ }^{45}$. Reactions triggered by TGase activity on proteins can be summarized as $\varepsilon-(\gamma$-glutamyl)lysine ( $\varepsilon-(\gamma$-Glu)Lys) crosslinking; therefore, giving TGase the nickname of "meat glue" ${ }^{45}$. For example, Lee et al. (1997), added microbial TGase at different concentrations $(0,0.1,0.2,0.3$, and $0.4 \%(\mathrm{w} / \mathrm{w}))$ into Alaska Pollock surimi pastes and either allowed the pastes to set for $1 \mathrm{~h}$ at $25^{\circ} \mathrm{C}$ prior to cooking or no gel setting period was applied ${ }^{46}$. It was observed that gel setting time and increased levels of TGase addition yielded stronger gels due to higher $\varepsilon$ $\left(\gamma\right.$-glutamyl) lysine dipeptide amount, as well as increased non-disulfide polymerization ${ }^{46}$. Another study showed confirmed that hake skin gelatin benefited from addition of $10 \mathrm{mg} / \mathrm{g}$ paste indicated by strong gel formation ${ }^{47}$. It is also important to note that mammalian or fish endogenous TGases, are calcium dependent meaning that calcium is necessary for enzymatic activity. On the other hand, external TGases like microbial TGase which is a variant of Streptoverticillium mobaraense is calcium independent. Using microbial TGase is preferable in 
some cases where there is a lack of calcium in the protein source or in food proteins that are susceptible to calcium like casein and globulins which precipitate in the presence of calcium ${ }^{48}$. Endogenous TGases, on the other hand are responsible for cross-linking myosin heavy chains, and formation of non-covalent and disulfide bonds during gel setting and cooking ${ }^{40}$. Therefore, incorporation of sarcoplasmic proteins that contain endogenous enzymes may increase rate of cross-linking between protein molecules. Moreover, endogenous tranglutaminase is a calcium dependent enzyme. Hence, increasing calcium content of protein gels may enhance gel network formation by increasing endogenous transglutaminase activity.

Potato starch absorbs water, gelatinizes and increases gel network strength by interacting with the protein molecules ${ }^{49}$, whereas, polyphosphates on the other hand induce myofibrillar protein solubility, similar to the addition of salts; therefore, increasing myosin binding strength 50. Wu, Lanier, and Hamann (1985) investigated the effects of starch on fish protein systems during thermal procedures and observed that type of starch used such as corn or potato has different impacts on gelation; however, adding any type of starch increased rigidity of fish protein gels ${ }^{51}$. Differential Scanning Calorimetry results showed different peaks and thermal transitions for each protein and starch groups and the salt or sucrose content of protein gels increased gelation temperatures of starch ${ }^{51}$. Tabilo-Munizaga, and Barbosa-Canovas (2004) added $4 \%$ potato starch into surimi gels and compared starch addition to egg white (1\% ovalbumin) incorporation where either sample has $2 \% \mathrm{NaCl}$ with a final paste moisture set at $78 \%{ }^{52}$. Potato starch increased lightness of thermally induced surimi gels; however, the combination of both egg white and potato starch increased lightness more than incorporation of potato starch alone ${ }^{52}$. On the other hand, potato starch and egg white incorporation increased 
yellowness of surimi gels and decreased gel hardness. Moreover, potato starch decreased gel cohesiveness of both Pacific whiting and Alaska Pollock gels ${ }^{52}$.

Different amounts of functional additives are used in protein gels. For example, Taskaya, Chen, and Jaczynski (2009) added 2\% salt (sodium chloride $(\mathrm{NaCl})$ ), $1 \%$ TGase, 3\% potato starch, $1 \%$ spray-dried beef plasma protein, $0.3 \%$ polyphosphates and $0.25 \%$ titanium dioxide (whitening agent) into isoelectrically recovered silver carp protein, set the final moisture of protein paste to either $84 \%$ or $78 \%$, and incubated the pastes at $4{ }^{\circ} \mathrm{C}$ for $24 \mathrm{~h}$ prior to cooking ${ }^{53}$ whereas, Tellez-Luis et al. (2002) tested 0,1 or $2 \% \mathrm{NaCl}, 0,0.3$ or $0.6 \%$ commercial microbial TGase (99\% maltodextrin, and $1 \%$ TGase), and $8 \%$ sucrose incorporation into silver carp protein pastes and incubated the pastes at $40{ }^{\circ} \mathrm{C}$ for 30 min followed by cooking ${ }^{54}$. Taskaya, Chen, and Jaczynski (2009) determined that functional additives increased functional properties indicated by thermal denaturation and viscoelasticity results ${ }^{53}$. Similarly, Tellez-Luis et al. (2002) concluded that increasing both additive ( $\mathrm{NaCl}$, and TGase) amounts resulted in harder and more cohesive gels as well as increased mechanical and functional gelation properties ${ }^{54}$. Moreover, increasing salt concentration reduced expressible water content whereas, TGase activity reduced protein solubility and unbound myosin amount ${ }^{54}$. Protein concentration and the composition of the initial source affects protein gelation. For example, $\mathrm{NaOH}$ processing was shown to increase sodium amount in the protein ${ }^{3}$; therefore, salt or polyphosphate added during the development of protein pastes may be adjusted accordingly.

There are different expectations from protein gels depending on the use. For example, reconstructed fish products are usually desired to be viscoelastic, and hard but not too firm, whereas, soft gels are preferred for tofu or soybean curd, and cheese products. Calcium lactate and calcium acetate were shown to yield softer gels ${ }^{55,56}$. Lu, Carter, and Chung (1980) tested 
calcium salts such as calcium chloride, calcium lactate, calcium acetate, calcium carbonate, calcium phosphate, calcium hydroxide, and calcium gluconate during preparation of soybean curd $^{55}$. It was observed that calcium chloride and calcium acetate was preferable due to the low volume of chemical used to precipitate soybean protein ${ }^{55}$. In a similar study where isoflavone content and tofu yields were assessed when different chemicals are used during tofu production, lowest amount of chemical to be added for curd formation was determined as calcium chloride 56 . Further comparison of calcium acetate, calcium lactate and calcium chloride showed that calcium lactate gave the highest tofu obtained $(\mathrm{g})$, followed by calcium chloride ${ }^{56}$. Moreover, isoflavone levels were similar when tofu was obtained using calcium chloride or calcium lactate; however, the total isoflavone level was lower when calcium acetate was used ${ }^{56}$. Lightness of tofu was slightly higher when calcium chloride was chosen as the processing chemical compared to the latter ${ }^{56}$. Yet, if a stronger gel is expected from the lactic acid processed protein, adjusting additive concentrations may be favorable.

Overall, protein gelation initiates by partial denaturation of myofibrillar protein, followed by heat induced aggregation and formation of disulfide bonds between actin and myosin which are the two major groups of proteins found in fish muscle tissues ${ }^{50}$. The cross-linking of proteins entraps gel constituents and forms a 3 -dimensional gel matrix ${ }^{50}$. Gel formation is affected by a variety of factors including $\mathrm{pH}$, ionic strength, processing strategies, protein concentration, and the interaction of additives such as calcium, salt, starch, fat, and transglutaminase with the myofibrillar protein that determine the final gel structure ${ }^{50}$. Therefore, gel additives must be selected according to the composition of the initial protein source used in gel pastes and the intended end product. 


\section{References}

1. Belitz, H. D.; Grosch, W.; Schieberle, P. Amino acids, peptides, proteins. In Food Chemistry, Belitz, H. D.; Grosch, W.; Schieberle, P., Eds. Springer-Verlag: Berlin Heidelberg, 2009, pp.889.

2. Gehring, C.K.; Gigliotti, J. C.; Moritz, J. S.; Tou, J. C.; Jaczynski, J. Functional and nutritional characteristics of proteins and lipids recovered by isoelectric processing of fish by-products and low-value fish: A review. Food Chem. 2011, 124, 422-431.

3. Paker, I.; Beamer, S.; Jaczynski, J.; Matak, K. E. Compositional characteristics of materials recovered from headed gutted silver carp (Hypophthalmichthys molitrix) by isoelectric solubilization and precipitation using organic acids. J. Food Sci. 2013, 78, E445-E451.

4. Taskaya, L.; Chen, Y.C.; Beamer, S.; Tou, J.C.; Jaczynski, J. Compositional Characteristics of Materials Recovered from Whole Gutted Silver Carp (Hypophthalmichthys molitrix) Using Isoelectrical Solubilization/ Precipitation. J. Agr. Food Chem. 2009, 57, 4259-4266.

5. Paker, I.; Beamer, S.; Jaczynski, J.; Matak, K. E. The effect of organic acids on gelation characteristics of protein gels made from silver carp (Hypophthalmichthys molitrix) protein recovered by isoelectric solubilization and precipitation. LWT - Food Sci. Technol. 2013, 53, 3743.

6. Paker, I.; Beamer, S.; Jaczynski, J.; Matak, K. E. pH shift protein recovery with organic acids on texture and color of cooked gels. J. Sci. Food Agr. 2015, 95, 275-280.

7. Kristinsson, H. G., Ingadottir, B. Recovery and properties of muscle proteins extracted from tilapia (Oreochromis niloticus) light muscle by $\mathrm{pH}$ shift processing. J. Food Sci. E: Food Engineering and Physical Properties, 2006, 71, E132-E141.

8. Chen, Y.C., Jaczynski, J. Protein recovery from rainbow trout (Oncorhynchus mykiss) processing byproducts via isoelectric solubilization/precipitation and its gelation properties as affected by functional additives. J. Agric. Food Chem. 2007, 55, 9079-9088.

9. Kim, Y. S., Park, J. W., Choi, Y J. New approaches for the effective recovery of fish proteins and their physicochemical characteristics. Fish. Sci. 2003, 69, 1231-1239. 
10. Taskaya, L., Chen, Y.C., Beamer, S., Jaczynski, J. Texture and Colour Properties of proteins recovered from whole gutted silver carp (Hypophthalmichthys molitrix) using isoelectric solubilization/ precipitation. J. Sci. Food Agric. 2009, 89, 349-358.

11. Kristinsson, H. G., Liang, Y. Effect of $\mathrm{pH}$-shift processing and surimi processing on Atlantic croaker (Micropogonias undulates) muscle proteins. J. Food Sci. 2006, 71, C304-C312.

12. Kristinsson, H. G., Hultin, H. O. Changes in conformation and subunit assembly of cod myosin at low and high pH and after subsequent refolding. J. Agric. Food Chem., 2003, 51, 7187-7196.

13. Ingadottir, B., Kristinsson, H. G. Gelation of protein isolates extracted from tilapia light muscle by pH shift processing. Food Chem., 2010, 118, 789-798.

14. Appel, L. J., Edward D. F., Hall, J. E., Pearson, T. A., Sacco, R. L., Seals, D. R., Sacks, F. M., Smith, S. C., Vafiadis, D. K., Van Horn, L. V. The importance of population-wide sodium reduction as a means to prevent cardiovascular disease and stroke a call to action from the American Heart Association. Circulation 123, 2011, 10, 1138-1143.

15. Tahergorabi, R., Beamer, S. K., Matak, K. E., Jaczynski, J. Isoelectric solubilization/precipitation as a means to recover protein isolate from striped bass (Morone saxatilis) and its physicochemical properties in a nutraceutical seafood product. J. Agric. Food Chem., 2012, 60 (23), pp 5979-5987.

16. Lu, J. Y;, Carter, E.; Chung, R. A. Use of calcium salts for soybean curd preparation. J. Food Sci. 1980, 45, 32-34.

17. Gomez, M. H.; McDonough, C. M.; Rooney, L.W.; Waniska, R. D. Changes in corn and sorghum during nixtamalization and tortilla baking. J. Food Sci. 1989, 54, 330-336.

18. Martínez-Bustos, F.; Chang, Y. K.; Bannwart, A.C.; Rodríguez, M. E.; Guedes, P.A.; Gaiotti, E. R. Effects of Calcium Hydroxide and Processing Conditions on Corn Meal Extrudates. Cereal Chem. 1998, 75(6), 796-801.

19. Clarke, R. J.; Lupfert, C. Influence of anions and cations on the dipole potential of phosphatidylcholine vesicles: a basis for the Hofmeister effect. Biophys. J. 1999, 76, 2614-2624. 
20. McPherson, A., Gavira, J. A. Introduction to protein crystallization. Structural Biol. Comm., 2014, 70, 2-20.

21. Paredi, M. E., Tomas, M. C., Crupkin, M., Afion, M. C. Thermal denaturation of Aulacomya ater ater (Molina) myofibrillar proteins: a differential scanning calorimetric study. J. Agr. Food Chem., 1994, 42, 873-877.

22. Otto, R. A., Beamer, S., Jaczynski, J., Matak, K.E. The effect of using citric or acetic acid on survival of Listeria monocytogenes during fish protein recovery by isoelectric solubilization and precipitation process. J. Food Sci., 2011a, 76(8), M579-M583.

23. Otto, R.A., Paker, I., Bane, L., Beamer, S., Jaczynski, J., Matak, K.E. Survival of Listeria inoccua in rainbow trout protein recovered by isoelectric solubilization and precipitation with acetic and citric acids. J. Food Prot., 2011b, 74(8), 1348-1352.

24. Bourtoom, T.; Chinnan, M. S.; Jantawat, P.; Sanguandeeku, R. Recovery and characterization of proteins precipitated from surimi wash-water. LWT-Food Sci. Technol. 2009, 42, 599-605.

25. Lin, T. M.; Park, J. W.; Morrissey, M. T. Recovered protein and reconditioned water from surimi processing waste. J. Food Sci. 1995, 60, 4-9.

26. Morrissey, M. T.; Park, J. W.; Huang, L. Surimi processing waste. Its control and utilization. In Surimi and Surimi Seafood; Park, J. W., Ed.: Marcel Dekker, New York, NY, USA, 2000; pp.127-165.

27. Park, J. W.; Morrissey, M. T. Manufacturing of surimi from light muscle fish. In Surimi and Surimi Seafood; Park, J. W., Ed.: Marcel Dekker, New York, NY, USA, 2000: pp. 23-58.

28. Okada, M. Effect of washing on the jelly forming ability of fish meat. Nippon Suis. Gakk., 1964, 30, 255-261

29. Macfarlane, J.J., Schmidt, G.R., Turner, R.H. Binding of meat pieces: a comparison of myosin, actomyosin and sarcoplasmic proteins as binding agents. J. Food Sci., 1977, 42(6), 16031605.

30. Piyadhammaviboon, P.; Yongsawatdigul, J. Proteinase inhibitory activity of sarcoplasmic proteins from threadfin bream (Nemipterus spp.). J. Sci. Food Agric. 2010, 90, 291-298. 
31. Jafarpour, A.; Gorczyca, E.M. Characteristics of sarcoplasmic proteins and their interaction with surimi and kamaboko gel. J Food Sci. 2009, 74, N16-N22.

32. Hemung, B. O., Chin, K. B. Effects of fish sarcoplasmic proteins on the properties of myofibrillar protein gels mediated by microbial transglutaminase. LWT-Food Sci. Technol., 2013, 53, 184-190.

33. Speroni, F., Jung, S., De Lamballerie, M. Effects of calcium and pressure treatment on thermal gelation of soybean protein. J. Food Sci., 2010, 75, E30-E38.

34. Scilingo, A. A., Anon, M. C. Characterization of Soybean Protein Isolates. The Effect of Calcium Presence. JAOCS, 2004, 81, 63-69.

35. J.E. Kinsella, D.M. Whitehead. Protein in whey: chemical, physical, and functional properties, In Advances in Food and Nutrition Research; volume 33, pp. 344-425. Academic Press, Inc. San Diego, CA, 1989.

36. Kuhn, P. R., Foegeding, E. A. Mineral salt effects on whey protein gelation. J. Agr. Food Chem., 1991, 39 (6), 1013-1016.

37. Barbut, S. Effects of calcium level on the structure of pre-heated whey protein isolate gels. $L W T$, 1995, 28, 598-603.

38. Ramírez, J.A., Rodriguez-Sosa, R., Morales, O. G., Vázquez M. Preparation of surimi gels from striped mullet (Mugil cephalus) using an optimal level of calcium chloride. Food Chem. 2003, 82, 417-423.

39. Benjakul, S., Chantarasuwan, C., Visessanguan, W. Effect of medium temperature setting on gelling characteristics of surimi from some tropical fish. Food Chem. 2003, 82,567-574.

40. Seki, N., Uno, H., Lee, N. H., Kimura, I., Toyoda, K., Fujita, T., Arai, K. Transglutaminase activity in Alaska pollack muscle and surimi and its reaction with myosin B. Nippon Suisan Gakk., 1990, 56(1), 125-132.

41. Alvarez, C.; Couso, I.; Tejada, M. Sardine surimi gels as affected by salt concentration, blending, heat treatment and moisture. J. Food Sci. 1995, 60(3), 622-626. 
42. Park, J.W.; Yongsawatdigul, J.; Lin, T.M. Rheological behavior and potential cross-linking of Pacific whiting (Merluccius productus) surimi gel. J. Food Sci. 1994, 59(4), 773-776.

43. Luo, Y., Kuwahara, R., Kaneniwa, M., Murata, Y., Yokoyama, M. Effect of soy protein isolate on gel properties of Alaska pollock and common carp surimi at different setting conditions. J. Sci. Food Agr., 2004, 84(7), 663-671.

44. Luo, Y., Kuwahara, R., Kaneniwa, M., Murata, Y., Yokoyama, M. Comparison of gel properties of surimi from Alaska Pollock and three freshwater fish species: effects of thermal processing and protein concentration. J. Food Sci., 2001, 66(3), 548-554.

45. Kuraishi, C.; Yamazaki, K.; Susa, Yasuyuki. transglutaminase: its utilization in the food industry. Food Review. Int. 2001, 17(2), 221-246.

46. Lee, H. G., Lanier, T. C., Hamann, D. D., Knopp, J. A. Transglutaminase Effects on Low Temperature Gelation of Fish Protein Sols J. Food Sci., 1997, 62, 20-24.

47. Fernández-Díaz, M. D., Montero, P., Gómez-Guillén, M. C. Gel properties of collagens from skins of cod (Gadus morhua) and hake (Merluccius merluccius) and their modification by the coenhancers magnesium sulphate, glycerol and transglutaminase. Food Chem., 2001, 74(2), 161167.

48. Motoki, M., Seguro, K. Transglutaminase and its use for food processing. Trend. Food Sci. Technol., 1998, 9, 204-210.

49. Hunt, A.; Getty, K. J.; Park, J. W. Development of temperature tolerant surimi gels using starch-protein interactions. J. Food Quality 2010, 33, 119-136.

50. Sun, X.D.; Holley, R.A. Factors influencing gel formation by myofibrillar proteins in muscle foods. Compr. Rev. Food Sci. F., 2011, 10, 33-51. 
51. Wu, M. C., Lanier, T. C., Hamann, D. D. Thermal transitions of admixed starch/fish protein systems during heating. J. Food Sci., 1985, 50, 20-25.

52. Tabilo-Munizaga, G., Barbosa-Canovas, V. Color and textural parameters of pressurized and heat-treated surimi gels as affected by potato starch and egg white. Food Research Int., 2004, 37 , 767-775.

53. Taskaya, L., Chen, Y. C., Jaczynski, J. Functional properties of proteins recovered from silver carp (Hypophthalmichthys molitrix) by isoelectric solubilization/precipitation. LWT- Food Sci. Technol., 2009, 42(6), 1082-1089.

54. Tellez-Luis, S., Uresti, R. M., Ramirez, J. A., Vazquez, M. Low-salt reconstructured fish products using microbial tranglutaminase as binding agent. J. Sci. Food Agr., 2002, 82, 953-959.

55. Lu, J. Y. Carter, E., Chung, R. A. Use of calcium salts for soybean curd preparation. J. Food Sci. 1980, 45, 32-34.

56. Prabhakaran, M. P.; Perera, C. O.; Valiyaveettil, S. Effect of different coagulants on the isoflavone levels and physical properties of prepared firm tofu. Food Chem. 2006, 99(3), 492499. 


\title{
CHAPTER 1
}

\section{Calcium Hydroxide as a Potential Base in Alkali Aided pH Shift Process}

\begin{abstract}
Protein was extracted from black bullhead catfish (Ameiurus melas) using a pH-shift method. Four alkali solubilization $\mathrm{pH}$ values $(11.0,11.5,12.0$, and 12.3) were tested using either sodium hydroxide $(\mathrm{NaOH})$ or calcium hydroxide $\left(\mathrm{Ca}(\mathrm{OH})_{2}\right)$ to solubilize protein. Precipitation of protein occurred at pH 5.5 using hydrochloric acid $(\mathrm{HCl})$. Compositional properties (protein, lipid, and ash) and mineral content, including $\mathrm{Ca}$ and $\mathrm{Na}$, of the recovered protein and lipid fractions were analyzed. When $\mathrm{Ca}(\mathrm{OH})_{2}$ was used as the processing base, the recovered protein and lipid fractions contained $92.1 \mathrm{~g} / 100 \mathrm{~g}$ protein and $99.7 \mathrm{~g} / 100 \mathrm{~g}$ lipid, respectively, which was greater $(\mathrm{p}<0.05)$ than values for $\mathrm{NaOH}$. These results indicate that $\mathrm{Ca}(\mathrm{OH})_{2}$ was more effective than $\mathrm{NaOH}$ at separating protein and lipids from other fractions. Protein solubilized using $\mathrm{Ca}(\mathrm{OH})_{2}$ had more $(\mathrm{p}<0.05) \mathrm{Ca}$ in the protein fraction; whereas, using $\mathrm{NaOH}$ increased $(\mathrm{p}<0.05)$ $\mathrm{Na}$ content. $\mathrm{Ca}(\mathrm{OH})_{2}$ is an effective processing base for $\mathrm{pH}$ shift protein recovery processes.
\end{abstract}

Keywords: Calcium hydroxide, $\mathrm{pH}$ shift, protein recovery, protein solubility, mineral analysis 


\section{Introduction}

Myofibrillar protein (MP) in fish consists of mainly actin and myosin which are valuable for the food industry due to their functionality and wide usage as an additive as well as the major protein source in surimi or fish sausages. Surimi processing is a conventional method of recovering fish protein where fish flesh is subjected to multiple cycles of washing to remove the undesirable fractions. This method accumulates a lot of processing water and results in the recovery of $25-28 \mathrm{~g} / 100 \mathrm{~g}$ of fish protein ${ }^{1}$. Another protein extraction method, called isoelectric solubilization and precipitation (ISP), does not generate as much waste water and has a greater protein recovery yield ranging from 35-66 g/100g depending on the protein solubilization strategy ${ }^{1,3}$. ISP uses $\mathrm{pH}$ shifts to separate impurities and lipids from myofibrillar protein by solubilizing and then precipitating it by adjusting the $\mathrm{pH}$ to the protein isoelectric point. The isoelectrically recovered protein has similar functionalities as surimi and can be made into protein gels, sausages or used as emulsifiers or foaming agents ${ }^{2}$. Similar to the surimi making process, greater protein recovery is desirable; therefore, improving the protein amount in the recovered protein fraction and the yield of the recovered protein fraction during ISP is essential.

The two major strategies used for protein solubilization is acidic and alkali solubilization. Acidic solubilization takes place when the initial $\mathrm{pH}$ of fish and water solution is decreased to extremely low $\mathrm{pH}$ values such as $\mathrm{pH} 2-3$; whereas, alkali solubilization happens when $\mathrm{pH}$ is increased to high $\mathrm{pH}$ values like $10.5-12^{4}$. Both strategies are effective in protein solubilization; however, alkali solubilization induces less protein denaturation ${ }^{3,5,6}$.

Sodium hydroxide $(\mathrm{NaOH})$ is widely used as the processing base during ISP; however, it will significantly increase sodium content in the recovered protein fraction ${ }^{3,7}$. In an effort to reduce sodium in the recovered protein, Tahergorabi and others (2012) replaced $\mathrm{NaOH}$ with 
potassium hydroxide $(\mathrm{KOH})$ as the ISP processing base. Results showed a decrease in protein functionality in restructured products ${ }^{7}$. This was attributed to a greater myosin denaturation possibly due to the denaturation or stabilization effect of each cation being different ${ }^{7,8}$. It was suggested that the changes in gelation patterns were due to differences between ion valence, charge, and size, with the larger K having weaker interactions with myosin than Na. This would result in less protection from the negative charges generated at alkaline $\mathrm{pH}$ thus making myofibrillar protein more susceptible to unfolding and denaturation ${ }^{7}$. Therefore, a processing base similar in atomic radii (a measurement of size) as Na may employ a similar stabilizing effect on protein confirmation during ISP.

Calcium hydroxide $\left(\mathrm{Ca}(\mathrm{OH})_{2}\right)$, a product of hydrated lime, is a widely used food additive and preservative ${ }^{9,10}$. Calcium fortified products such as infant formula are produced by adding $\mathrm{Ca}(\mathrm{OH})_{2}{ }^{11}$. Due to its low cost and generally recognized as safe status, $\mathrm{Ca}(\mathrm{OH})_{2}$ is a preferred calcium fortification agent ${ }^{12}$. Replacing the traditionally used $\mathrm{NaOH}$ during ISP with $\mathrm{Ca}(\mathrm{OH})_{2}$ as the processing base may result in a calcium fortified protein isolate with less Na. Therefore, the main objective of this study was to investigate the efficacy of $\mathrm{Ca}(\mathrm{OH})_{2}$ as a processing base during ISP compared to $\mathrm{NaOH}$. The differences in composition (protein, lipid, and ash amounts) of recovered protein and lipid fractions, lipid and protein recovery yields, and mineral contents of recovered proteins between applying different alkali solubilization $\mathrm{pH}$ values $(11.0,11.5,12.0$ and 12.3) were determined and compared.

2. Materials and Methods

2.1. Preparation of ground catfish 
Fresh black bullhead catfish (Ameiurus melas) were harvested from a fish hatchery (Dog Wood Lake, Morgantown WV) and placed in coolers containing ice and carbon monoxide. The fish were transported to the meats processing laboratory at West Virginia University where they were headed, gutted and rinsed under running tap water before being transferred onto steel trays. The fish were ground into a thick paste using a sanitized meat grinder (Hobart Model 4146, Troy, OH, USA) with a coarse grinder plate. The ground fish paste was stored on a lidded steel tray, chilled at $-20^{\circ} \mathrm{C}$ freezer overnight and then ground again using a fine grinder plate to grind into a finer paste. Fish paste (500 g) was individually weighed and separated into freezer bags (Ziplock Freezer Bags, S.C. Johnson \& Son, Inc., Racine, Wis., U.S.A.), vacuum packaged (Ultravac KOCH Packaging, KOCH Supplies Inc., Kansas City, MO, USA) and stored at $-80^{\circ} \mathrm{C}$ until analyses were conducted up to a maximum of 8 days.

2.2. Protein separation using isoelectric solubilization and precipitation (ISP)

A package of vacuum packaged fish containing $500 \mathrm{~g}$ of paste was thawed at $4^{\circ} \mathrm{C}$ for $24 \mathrm{~h}$ prior to processing. The thawed paste was diluted with distilled deionized water at a 1:6 (fish: water) ratio in a glass beaker and homogenized (PowerGen 700, Fisher Scientific, Pittsburgh, PA) for $5 \mathrm{~min}^{3}$. In order to solubilize protein and separate the lipids and insoluble (skin, bones, and scales) fractions, the $\mathrm{pH}$ of the solution was increased to either 11.0, 11.5, 12.0 or 12.3 with $1 \mathrm{~mol} \mathrm{~L}^{-1}$ calcium hydroxide $\left(\mathrm{Ca}(\mathrm{OH})_{2}\right)$ or $10 \mathrm{~mol} \mathrm{~L}^{-1}$ sodium hydroxide $(\mathrm{NaOH})$. The solution was homogenized for $10 \mathrm{~min}$ after the final $\mathrm{pH}$ was reached and confirmed with a calibrated pH/ion analyzer (Oakton, Eutech Instruments; Singapore). To separate the lipids and insolubles from the protein solution, the slurry was transferred into $1 \mathrm{~L}$ centrifuge bottles and centrifuged at $98066.5 \mathrm{~m} \mathrm{~s}^{-2}$ for $15 \mathrm{~min}$ at $4^{\circ} \mathrm{C}$ (Sorvall RC-SB Refrigerated Superspeed Centrifuge, Du Pont, Wilmington, DE, USA) ${ }^{3}$. Following centrifugation, lipids formed the top layer, protein 
solubilized in the liquid fraction, and the insoluble components were at the bottom. The solubilized protein solution was filtered through cheese cloth in to a glass beaker and the $\mathrm{pH}$ was adjusted to 5.5, the protein isoelectric point, using hydrochloric acid $(\mathrm{HCl})$. The solution was homogenized for an additional $5 \mathrm{~min}$ after $\mathrm{pH}$ was stabilized at $5.5^{3}$. Upon being transferred into 1L centrifuge bottles, the solution was spun by centrifugation at $98066.5 \mathrm{~m} \mathrm{~s}^{-2}$ for $15 \mathrm{~min}$ at $4^{\circ} \mathrm{C}$

${ }^{3}$. The precipitated protein formed a pellet which was retained and the process water discarded ${ }^{3}$.

The collected fractions (lipids and protein) were frozen at $-80^{\circ} \mathrm{C}$, and transferred to a freeze-dryer (VirTis Genesis, SP Scientific, Gardiner, N.Y., U.S.A.) to remove excess moisture. The freeze-dried samples were stored at refrigeration temperatures $\left(4^{\circ} \mathrm{C}\right)$ until they were analyzed.

\subsection{Protein Solubility}

Protein solubility was tested for each solubilization $\mathrm{pH}$ and base used during the ISP protein recovery process. Fish $(250 \mathrm{~g})$ was thawed, diluted at a 1:6 (fish: distilled water) ratio and homogenized (PowerGen 700, Fisher Scientific, Pittsburgh, PA) in a glass beaker. The initial $\mathrm{pH}$ of the fish and distilled water solution was determined as 6.5 using a $\mathrm{pH} / \mathrm{ion}$ analyzer (Oakton, Eutech Instruments; Singapore). Either $\mathrm{NaOH}$ or $\mathrm{Ca}(\mathrm{OH})_{2}$ were used to increase the $\mathrm{pH}$ to basic levels (7-12.5), and $50 \mathrm{ml}$ samples were collected in a centrifuge bottle at every 0.5 change in $\mathrm{pH}$ units. The samples were then centrifuged at 10,000 $\mathrm{x}$ g for $15 \mathrm{~min}$ (Eppendorf, Micro-centrifuge $5430 \mathrm{R}$ with F-35-6-30 rotor, Hamburg, Germany) ${ }^{13}$. The supernatant was filtered through a cheese cloth and a $20 \mu \mathrm{l} / \mathrm{ml}$ sample was drawn with a pipette for running Bradford protein analysis. Bradford protein assay involves dying the protein using Coomassie Brilliant Blue G-250 and taking measurements at $\mathrm{A}=595 \mathrm{~nm}$ to determine the amount of protein in the solution. The protein samples were tested against a standard curve at known 
concentrations of bovine serum albumin $(\mathrm{BSA}){ }^{14}$. Protein solubility percentages were calculated using the following equation ${ }^{13}$;

$$
\text { Protein Solubility } \%=\frac{\text { soluble protein in sample }(\mathrm{mg} / \mathrm{ml})}{\text { soluble protein in ground fish }(\mathrm{mg} / \mathrm{ml})}
$$

\subsection{Proximate analyses}

Proximate composition (ash, fat, and crude protein) of recovered protein, lipid, and initial starting material (ground, beheaded and gutted catfish) was determined according to the Association of Official Analytical Chemists (1995) to assess the efficiency of using different solubilization strategies during ISP ${ }^{15}$. The results are displayed as mean \pm standard deviation of 3 separate replications presented as $\mathrm{g} / 100 \mathrm{~g}$ of sample, dry basis.

\subsubsection{Moisture Content}

Moisture of the freeze-dried samples was verified using the oven-drying method (Fisher Scientific, Fairlawn, NJ). Approximately 1-2 g of each sample was spread on aluminum pans in triplicates and dried for $24 \mathrm{~h}$ at $105^{\circ} \mathrm{C}^{3}$. The initial and final weights of the samples were recorded and the moisture content was calculated.

\subsubsection{Ash Content}

Dried samples (0.5-1 g) were incinerated in triplicates in a muffle furnace oven (Fisher Scientific, Fairlawn, NJ) at $550^{\circ} \mathrm{C}$ for 24 h to determine ash content ${ }^{3}$. The initial and final weight were recorded and the ash content was calculated on a dry weight basis.

\subsubsection{Fat and Crude Protein Content}


The total fat content was determined using the Soxhlet extraction method where $2 \mathrm{~g}$ of each sample was wrapped in Whatman No.41 filter paper and fat extraction was achieved by dripping petroleum ether ${ }^{3}$. The initial weight of each sample and the dried final weights were recorded. Kjedahl analysis was used to measure the amount of crude protein in each sample using Kjeldahl analyzer (Kjeltec 2300, Tecator Technology, Foss, Hillerød, Denmark) ${ }^{3}$. Samples were analyzed in triplicates per solubilization treatment and results were reported on a dry weight basis.

\subsection{Protein and Lipid Recovery Yields}

Protein and lipid recovery yields were calculated using the following formulae to assess the efficiency of each solubilization strategy ${ }^{3}$.

Protein recovery yield $=\frac{\text { weight of recovered catfish protein }(\mathrm{g})(\text { Kjeldahl, drybasis })}{\text { weight of protein in ground catfish paste }(\mathrm{g})(\text { Kjeldahl, drybasis })}$

Lipid recovery yield $=\frac{\text { weight of recovered catfish lipid }(\mathrm{g})(\text { Soxhlet, drybasis })}{\text { weight of lipid in ground catfish paste }(\mathrm{g})(\text { Soxhlet, drybasis) }}$ 2.6. Mineral profile analysis

Approximately 1-2 g of ashed recovered protein and Alaska Pollock surimi samples were dissolved in $2 \mathrm{~mL}$ of $70 \%$ nitric acid and diluted with distilled deionized $(\mathrm{d} / \mathrm{d})$ water. The solution was then filtered through Whatman No.1 filter paper and further diluted with d/d water in a $50 \mathrm{~mL}$ flask ${ }^{3}$. The mineral profile (iron $(\mathrm{Fe})$, magnesium $(\mathrm{Mg})$, calcium $(\mathrm{Ca})$, phosphorus (P), and sodium $(\mathrm{Na})$ ) amounts of protein recovered using each solubilization strategy, and the initial starting material were determined using inductively coupled plasma optical emission spectrometry (model P400; Perkin-Elmer, Shelton, CT) ${ }^{3}$. The glassware and the crucibles used 
in the analyses were kept in a $10 \% \mathrm{HCl}$ solution overnight in order to avoid any foreign particle interference.

\subsection{Statistical analysis}

Applied solubilization strategies were randomized using JMP software version 10.2 (SAS Inst., Cary, NC, USA) prior to experimentation. ISP was replicated 3 times per solubilization strategy. The proximate and mineral analyses were also replicated 3 times for each ISP treatment. Data was presented as mean \pm standard deviation and analyzed by one-way analysis of variance (ANOVA) with a significance set at 0.05 . The differences in mean data points were determined with Tukey's honestly significant differences test $(\mathrm{p}<0.05)$ using JMP 10.2 (SAS Inst., Cary, NC, USA). The statistical analysis shown in the figures and tables, indicated by a,b,c,d,e are obtained by comparing all of the applied solubilization strategies within one column or category. Moreover, bold values indicate significant differences between $\mathrm{NaOH}$ and $\mathrm{Ca}(\mathrm{OH}) 2$ within the same column and the same solubilization $\mathrm{pH}$ (one way ANOVA test, $\mathrm{p}<0.05$ ). Further statistical analysis comparing the significant differences $(\mathrm{p}<0.05)$ between solubilization $\mathrm{pH}$ values achieved using either $\mathrm{NaOH}$ or $\mathrm{Ca}(\mathrm{OH})_{2}$ within each category are performed using Tukey's honestly significant differences test for the protein and lipid concentrations in protein and lipid fracions, respectively. For mineral analysis, 3 different statistical analysis are performed. Table 2 shows significant $(\mathrm{p}<0.05)$ differences between mean values of $\mathrm{pH}$ recovery treatments indicated by a,b,c,d,e,f $u$ using Tukey's honestly significant differences test, where bold values indicate significant differences $(\mathrm{p}<0.05)$ between solubilization bases within the same solubilization $\mathrm{pH}$ group. Table 3 presents comparisons between mean values of protein fractions recovered using $\mathrm{pH}$ shift treatments and ground catfish indicated by a,b,c,d,e,f for each mineral tested determined using Tukey's honestly significant differences test, $\mathrm{p}<0.05)$. The second set of 
analysis shown with ${ }^{\mathrm{t}, \mathrm{u}, \mathrm{v}, \mathrm{w}, \mathrm{x}, \mathrm{y}, \mathrm{z}}$ shows significant differences between mean values of protein fractions recovered using $\mathrm{pH}$ shift treatments and Alaska Pollock surimi for each mineral tested (Tukey's honestly significant difference test, $\mathrm{p}<0.05$ ).

\section{Results and Discussion}

\subsection{Protein Solubility and Proximate Composition of the Recovered Fractions}

Figure 1 shows that protein was more soluble when $\mathrm{Ca}(\mathrm{OH})_{2}$, instead of $\mathrm{NaOH}$, was used as the processing base during ISP processing, regardless of solubilization $\mathrm{pH}$. Increasing the $\mathrm{pH}$ of a solution by adding a base during alkali solubilization promotes amino acid (such as lysly and cysteine residues) deprotonation ${ }^{4,16}$. This leads to increased negative surface charge that induces protein-protein electrostatic repulsion followed by protein-water electrostatic interactions ${ }^{17}$. As the reactions continue, protein-protein interactions decrease and protein-water interactions increase while the protein becomes more charged ${ }^{18}$. Evidently, water molecules link to and surround the protein making it soluble ${ }^{4}$. Therefore, the more polar the protein gets, the more soluble it becomes in water. The unfolded state of protein achieved by the increased net charge is closely related to electronegativity ${ }^{19}$. According to Pauling Electronegativity Scale, Na has an electronegativity of 0.93 , whereas Ca's electronegativity is $1.0^{20}$. Ionization energy increases as electronegativity increases, which may explain the greater $(\mathrm{p}<0.05)$ protein solubility displayed by $\mathrm{Ca}(\mathrm{OH})_{2}$ compared to $\mathrm{NaOH}$ at every alkali $\mathrm{pH}$ (7-12.3) tested (Figure 1).

Protein solubility is dependent on both intrinsic (amino acid composition, and surface area of the protein), and extrinsic factors ( $\mathrm{pH}$, ionic strength, temperature, and salt concentration of the environment ${ }^{16}$. Some salts have destabilizing effects and bind to protein extensively; thereby increasing surface tension and decreasing protein-protein interaction ${ }^{21}$. The 
effectiveness of different salts in increasing protein solubility depends on the $\mathrm{pH}$ of the solution and the isoelectric point $(\mathrm{pI})$ of the protein. Clarke et al. (1999) demonstrated that when $\mathrm{pH}$ of the solution was greater than the pI of protein, the effectiveness of ions followed the Hofmeister sequence ${ }^{22}$. Therefore, as indicated by the results of this study, Ca may be more effective in solubilizing proteins compared to $\mathrm{Na}$ following the Hofmeister order of cations in an alkali process due to increased hydrophobic surface area and dipole moment ${ }^{22,23}$.

Proximate composition of the recovered protein fraction shown in Table 1 revealed that protein concentration was greater $(\mathrm{p}<0.05)$ (dry weight basis) when $\mathrm{Ca}(\mathrm{OH})_{2}$ was used as the processing base compared to $\mathrm{NaOH}$ at every solubilization $\mathrm{pH}$ tested in this study. This may be explained by the greater $(\mathrm{p}<0.05)$ protein solubility displayed by $\mathrm{Ca}(\mathrm{OH})_{2}($ Figure 1$)$. Protein concentration in the recovered protein fraction had a range of 89-92 $\mathrm{g} / 100 \mathrm{~g}$ when $\mathrm{Ca}(\mathrm{OH})_{2}$ was used; when $\mathrm{NaOH}$ was used as the processing base protein concentration ranged from 74-84 $\mathrm{g} / 100 \mathrm{~g}$ which was significantly less $(\mathrm{p}<0.05)$. However, our protein concentration results for $\mathrm{NaOH}$ as the processing base are consistent with previously reported alkali solubilization data where protein amount was in the range of $51-82 \mathrm{~g} / 100 \mathrm{~g}^{3}$. These results indicate that $\mathrm{Ca}(\mathrm{OH})_{2}$ was more effective than $\mathrm{NaOH}$ at separating protein from the other fractions.

When $\mathrm{NaOH}$ was used as the processing base, protein concentration was highest in the protein fractions solubilized at $\mathrm{pH}$ values 12.0 and $12.3(\mathrm{p}<0.05)$ (Figure 2). On the other hand, when $\mathrm{Ca}(\mathrm{OH})_{2}$ was used as the processing base, there was a significant $(\mathrm{p}<0.05)$ rise in protein concentration when protein was solubilized at $\mathrm{pH} 12.0$ followed by a significant decrease in fractions solubilized at $\mathrm{pH} 12.3$ (Figure 2). Since $\mathrm{Ca}(\mathrm{OH})_{2}$ dissociates into $\mathrm{Ca}^{2+}$ and $2\left(\mathrm{OH}^{-1}\right)$ in aqueous solutions the trend where there is a reduction in protein recovery $(\mathrm{p}<0.10)$ may have 
been because the solution reached saturation after $\mathrm{pH}$ 12.0. For example, the solubility constant $\left(\mathrm{K}_{\mathrm{sp}}\right)$ of $\mathrm{Ca}(\mathrm{OH})_{2}$ is $5.5 \times 10^{-6}$ at room temperature $\left(25^{\circ} \mathrm{C}\right)^{24}$.

$$
\begin{aligned}
& \mathrm{Ca}(\mathrm{OH})_{2} \longrightarrow \mathrm{Ca}^{2+}+2\left(\mathrm{OH}^{-1}\right) \\
& \mathrm{K}_{\mathrm{sp}}=\left[\mathrm{Ca}^{+2}\right]\left[\mathrm{OH}^{-}\right]^{2}=5.5 \times 10^{-6}
\end{aligned}
$$

Therefore, the molar solubility of $\mathrm{Ca}(\mathrm{OH})_{2}$ can be determined using the following equation where " $\mathrm{x}$ " is the molar concentration of $\mathrm{Ca}^{+2}$ and " $2 \mathrm{x}$ " is the molar concentration of $\mathrm{OH}^{-}$:

$$
\mathrm{K}_{\mathrm{sp}}=(\mathrm{x})(2 \mathrm{x})^{2}=5.5 \times 10^{-6}
$$

Solving for $\mathrm{x}$ will reveal that the molar concentration of $\mathrm{Ca}^{+2}$ equals $0.01 \mathrm{M}$, whereas the molar concentration of $\mathrm{OH}^{-}$will be $0.02 \mathrm{M}^{25}$. From the following equations ${ }^{26}$;

$\mathrm{pOH}=-\log \left[\mathrm{OH}^{-}\right]$and $\mathrm{pK}=\mathrm{pH}+\mathrm{pOH}=14 ; \mathrm{pOH}$ is calculated as 1.7 , leaving the $\mathrm{pH}$ of saturation as 12.3 at $25^{\circ} \mathrm{C}$ when $\mathrm{Ca}(\mathrm{OH})_{2}$ is used. In order to prevent protein from denaturing, this current experiment was conducted at $4^{\circ} \mathrm{C}$ which may have caused the saturation of the solution to occur just after $\mathrm{pH} 12.0$ which showed the greatest protein solubility. On the contrary, $\mathrm{NaOH}$ is highly soluble in water and may have not reached saturation at $\mathrm{pH} 12.3$ which may explain the increase in protein solubility as the $\mathrm{pH}$ became more alkaline. Furthermore, $\mathrm{NaOH}$ emits $\mathrm{Na}$ with a single positively charged ion and one $\mathrm{OH}$ - per molecule as it dissociates, compared to $\mathrm{Ca}(\mathrm{OH})_{2}$ which dissociates into $\mathrm{Ca}$ and $2(\mathrm{OH}-)$ making more ions available in the solution to be bound to amino acids. Therefore, increasing the $\mathrm{pH}$ of solubilization would require a greater concentration of $\mathrm{NaOH}$, which may therefore increase the solubilization properties of $\mathrm{NaOH}$. 
Ash content, an indicator of impurities such as scales and bones that were not removed from the protein fraction, increased as solubilization $\mathrm{pH}$ value increased when $\mathrm{Ca}(\mathrm{OH})_{2}$ was used. On the contrary, when $\mathrm{NaOH}$ was used as the processing base, the amount of ash in the protein fraction decreased $(\mathrm{p}<0.05)$ as solubilization $\mathrm{pH}$ increased. Recovered protein fraction with the greatest $(\mathrm{p}<0.05)$ ash content was observed at solubilization $\mathrm{pH}$ values 11.0 and 11.5 using $\mathrm{NaOH}$. Another impurity indicator is lipid concentration in the protein fraction which was greatest $(\mathrm{p}<0.05)$ when $\mathrm{NaOH}$ was used as the processing base at every solubilization $\mathrm{pH}$ tested. $\mathrm{Ca}$ is effective at separating membranes from solubilized proteins by inducing their detachment from cytoskeletal proteins ${ }^{27}$. This may explain why $\mathrm{Ca}(\mathrm{OH})_{2}$ separated lipids more efficiently from the protein fraction during isoelectric solubilization.

ISP application can also salvage lipids from hard to process resources. The proximate composition of the recovered lipid fractions differed greatly depending on the solubilization strategy applied (Table 1). The lipid amount in the recovered lipid fraction ranged from 72-100 $\mathrm{g} / 100 \mathrm{~g}$ when $\mathrm{Ca}(\mathrm{OH})_{2}$ was used, and 70-96 $\mathrm{g} / 100 \mathrm{~g}$ when $\mathrm{NaOH}$ was selected as the processing base. The greatest $(\mathrm{p}<0.05)$ concentration of lipid in the lipid fraction was reached by using a solubilization $\mathrm{pH}$ of 12.3 with $\mathrm{Ca}(\mathrm{OH})_{2}$. This strategy also yielded the lowest ash and protein impurities in the lipid fraction.

Previous studies investigating the composition of isoelectrically recovered lipid fractions from silver carp using $\mathrm{NaOH}$ as the processing base reported lipid amounts of $60 \mathrm{~g} / 100 \mathrm{~g}, 73$ $\mathrm{g} / 100 \mathrm{~g}, 94 \mathrm{~g} / 100 \mathrm{~g}$ and $96 \mathrm{~g} / 100 \mathrm{~g}$ in the recovered lipid fractions for solubilization $\mathrm{pH}$ values $11.5,12.0,11.5$ and 12.5 , respectively ${ }^{3,28}$. This is consistent with the results observed in this study. It was also noted that when $\mathrm{NaOH}$ was used as the processing base, lipid quantity in the recovered lipid fraction was greatest $(\mathrm{p}<0.05)$ at solubilization $\mathrm{pH} 11.0$, on the other hand, 
applying a solubilization $\mathrm{pH}$ of 12.3 yielded the greatest $(\mathrm{p}<0.05)$ lipid amount in the recovered lipid fraction when $\mathrm{Ca}(\mathrm{OH})_{2}$ was used (Figure 3). Lipid amount was more $(\mathrm{p}<0.05)$, and the impurities (ash and protein content) were less $(\mathrm{p}<0.05)$ at every solubilization $\mathrm{pH}$ tested up to 12.3 when $\mathrm{NaOH}$ was used as the processing base compared to $\mathrm{Ca}(\mathrm{OH})_{2}$; however, the effectiveness of a processing strategy also depends on the amount of protein and lipid recovered. Therefore protein and lipid recovery yields were also calculated.

\subsection{Protein and Lipid Recovery Yields}

Recovery yield is an important parameter for determining the efficacy and the economic feasibility of an extraction process. Although, protein concentration in the recovered protein fraction is an important determinant of the efficiency of the separation, it is also essential to employ strategies that increase the yield which takes the amount of protein recovered into account. For example, the recovered lipid was extremely pure $(99.7 \mathrm{~g} / 100 \mathrm{~g})$ when solubilized at pH 12.3 using $\mathrm{Ca}(\mathrm{OH})_{2}$; however, the yield was lower $(11 \mathrm{~g} / 100 \mathrm{~g})$ compared to rest of the applied strategies (Figure 4, Table 1).

Protein recovery yield ranges did not vary greatly depending on the processing base, where a range of $42-52 \mathrm{~g} / 100 \mathrm{~g}$ was seen in fractions recovered using $\mathrm{Ca}(\mathrm{OH})_{2}$ and $46-57 \mathrm{~g} / 100 \mathrm{~g}$ using $\mathrm{NaOH}$. There was a more evident gap between lipid recovery ranges. At solubilization $\mathrm{pH}$ 11.0, 11.5 and $12.0 \mathrm{Ca}(\mathrm{OH})_{2}$ had better recovery $(\mathrm{p}<0.05)$ than $\mathrm{NaOH}$, with a range of $71-85$ $\mathrm{g} / 100 \mathrm{~g}$; whereas $\mathrm{NaOH}$ as the processing base yielded a lipid recovery range of $22-45 \mathrm{~g} / 100 \mathrm{~g}$. This may be explained by the proximate composition data where it was concluded that $\mathrm{Ca}(\mathrm{OH})_{2}$ may be more effective in removing the lipids linked to the bones. Additionally, it was observed that $\mathrm{Ca}(\mathrm{OH})_{2}$ was not very effective at $\mathrm{pH} 12.3$, with a recovery yield of $11 \mathrm{~g} / 100 \mathrm{~g}$, possibly due to low solubility and saturation in aqueous solutions. 
Solubilization $\mathrm{pH}$ also played a significant role in recovery yields similar to that of the proximate composition. When $\mathrm{Ca}(\mathrm{OH})_{2}$ was added as the processing base, protein recovery yield increased with the increasing solubilization $\mathrm{pH}$; however, the opposite trend was true for the lipid recovery yield (Figure 5, Figure 6). Data obtained by using $\mathrm{NaOH}$ showed more consistent results between the two recovery yields where solubilization $\mathrm{pH} 12.0$ gave the greatest protein and lipid recovery yields (Figure 5, Figure 6). It is also important to note that, using $\mathrm{NaOH}$ showed greater $(\mathrm{p}<0.05)$ protein recovery yields compared to $\mathrm{Ca}(\mathrm{OH})_{2}$ at $\mathrm{pH}$ values $\mathrm{pH} 11.0$ and 12.0. Whereas, using $\mathrm{Ca}(\mathrm{OH})_{2}$ as the processing base showed greater $(\mathrm{p}<0.05)$ lipid recovery yield for all solubilization $\mathrm{pH}$ values tested except for $\mathrm{pH} 12.3$.

Overall, the recovery yields calculated in this study are slightly lower than the reported values from previous publications ${ }^{3,29}$. This may be due to the low dilution factor used during the homogenization step. Previous studies suggested that dilution factor is an important factor affecting protein solubility, and that a dilution factor of 36 or greater increases protein recovery yield ${ }^{30,31}$. In this study a dilution factor of 6 was applied in order to be able to directly compare results to previously obtained results from the same laboratory. Therefore, increasing the dilution ratio of initial ground fish to water might increase the recovery yields.

\subsection{Mineral Content}

The mineral content (Iron (Fe), Magnesium (Mg), Calcium (Ca), Phosphorus (P), and Sodium (Na)) of the recovered protein fractions was determined for each $\mathrm{pH}$ shift strategy and compared to the initial ground catfish and Alaska Pollock surimi was assessed (Table 2, Table 3, Figure 7, Figure 8). Mineral content differed with the changing solubilization $\mathrm{pH}$ and base used. As expected, when $\mathrm{Ca}(\mathrm{OH})_{2}$ was used as the processing base, there was more $\mathrm{Ca}$ in the recovered protein $(\mathrm{p}<0.05)$. Ca content also increased as solubilization $\mathrm{pH}$ increased $(\mathrm{p}<0.05)$ 
due to the increased amount of $\mathrm{Ca}(\mathrm{OH})_{2}$ added to the solution (Figure 7). A similar trend $(\mathrm{p}<0.10)$ was seen when $\mathrm{NaOH}$ was used as the processing base where Ca content increased $(\mathrm{p}<0.05)$ as the solubilization $\mathrm{pH}$ value increased (Figure 8$)$. This may be due to the increased solubility of $\mathrm{Ca}$ from the fish bones as the $\mathrm{pH}$ increases. Interestingly, $\mathrm{Na}$ content did not increase with increasing solubilization $\mathrm{pH}$ value when $\mathrm{NaOH}$ was used. $\mathrm{Na}$ amount was the greatest $(\mathrm{p}<0.05)$ when protein was solubilized at $\mathrm{pH} 11.5$, and was reduced $(\mathrm{p}<0.05)$ as solubilization $\mathrm{pH}$ increased (Figure 8). It is possible that as $\mathrm{pH}$ increases, due to the increase in osmotic pressure the protein fraction cannot take up more than a certain amount of Na.

The mineral contents of the recovered protein fractions were also compared to Alaska Pollock surimi which is considered the industry standard (Table 3). Fe content was greater $(\mathrm{p}<0.05)$ whereas $\mathrm{Mg}$ content was lower $(\mathrm{p}<0.05)$ in recovered protein fractions independent of solubilization treatment. This may be due to the Alaska Pollock surimi being made out of washed fish flesh which would contribute to the removal of blood and connective tissue ${ }^{33}$. It is difficult to hypothesize about the differences between Alaska Pollock surimi and black bullhead catfish protein because the mineral compositions differ greatly between fish species. On the other hand, $\mathrm{Ca}$ and $\mathrm{Na}$ amounts in the recovered protein fractions were dependent on the processing bases added during protein solubilization. Overall, using $\mathrm{Ca}(\mathrm{OH})_{2}$ yielded a protein with more calcium $(\mathrm{p}<0.05)$ than Alaska Pollock surimi, whereas, processing with $\mathrm{NaOH}$ resulted in a protein fraction with more $(\mathrm{p}<0.05)$ sodium compared to the initial starting material as well as Alaska Pollock. In conclusion, $\mathrm{Ca}(\mathrm{OH})_{2}$ is an effective processing base for $\mathrm{pH}$ shift protein recovery processes.

\section{Abbreviations Used}

$\mathrm{NaOH}$ : sodium hydroxide 
$\mathrm{Ca}(\mathrm{OH}) 2$ : calcium hydroxide

$\mathrm{HCl}$ : hydrochloric acid

ISP: Isoelectric solubilization and precipitation

pI: Isoelectric point

$\mathrm{K}_{\mathrm{sp}}$ : Solubility constant

s: Molar solubility

Fe: Iron

Mg: Magnesium

Ca: Calcium

P: Phosphorus

Na: Sodium

5. Acknowledgements

This work was funded by the HATCH Program Project \# (WVA 00622). 
References

1. Kim, Y. S.; Park, J. W.; Choi, Y. J. New approaches for the effective recovery of fish proteins and their physicochemical characteristics. Fisheries Sci. 2003, 69, 1231-1239.

2. Paker, I.; Matak, K.E. Pre-Cooking Protein Paste Gelation Conditions and Post-Cooking Gel Storage Conditions on Gel Texture. J. Sci. Food Agr. 2015, Accepted for publication.

3. Paker, I.; Beamer, S.; Jaczynski, J.; Matak, K. E. Compositional characteristics of materials recovered from headed gutted silver carp (Hypophthalmichthys molitrix) by isoelectric solubilization and precipitation using organic acids. J. Food Sci. 2013, 78, E445-E451.

4. Gehring, C.K.; Gigliotti, J. C.; Moritz, J. S.; Tou, J. C.; Jaczynski, J. Functional and nutritional characteristics of proteins and lipids recovered by isoelectric processing of fish by-products and low-value fish: A review. Food Chem. 2011, 124, 422-431.

5. Paker, I.; Beamer, S.; Jaczynski, J.; Matak, K. E. The effect of organic acids on gelation characteristics of protein gels made from silver carp (Hypophthalmichthys molitrix) protein recovered by isoelectric solubilization and precipitation. LWT - Food Sci. Technol. 2013, 53, 3743.

6. Paker, I.; Beamer, S.; Jaczynski, J.; Matak, K. E. pH shift protein recovery with organic acids on texture and color of cooked gels. J Sci. Food Agr. 2015, 95, 275-280.

7. Tahergorabi, R.; Beamer, S.; Matak, K.E.; Jaczynski, J. Isoelectric solubilization/precipitation as a means to recover protein isolate from striped bass (Morone saxatilis) and its physicochemical properties in a nutraceutical seafood product. J. Agric. Food Chem. 2012, 60(23), 5979-5987.

8. Raghavan, S.; Kristinsson, H. G. Conformational and rheological changes in catfish myosin during alkali-induced unfolding and refolding. Food Chem. 2008, 107, 385-398.

9. Lu, J. Y;, Carter, E.; Chung, R. A. Use of calcium salts for soybean curd preparation. J. Food Sci. 1980, 45, 32-34.

10. Gomez, M. H.; McDonough, C. M.; Rooney, L.W.; Waniska, R. D. Changes in corn and sorghum during nixtamalization and tortilla baking. J. Food Sci. 1989, 54, 330-336. 
11. Kashyap, S. Enteral Intake for Very Low Birth Weight Infants: What Should the Composition Be? Semin. Perinatol. 2007, 31, 74-82.

12. United States Food and Drug Administration. Safe and suitable ingredients used in the production of meat, poultry, and egg products. 7120.1, Rev. 23. United States Department of Agriculture Food Safety and Inspection Service: Washington, D. C., 2014.

13. Kristinsson, H. G.; Liang, Y. Effect of $\mathrm{pH}$-shift processing and surimi processing on atlantic croaker (Micropogonias undulates) muscle proteins. J. Food Sci.: Food Sci Toxic. 2006, 71, C304-312.

14. Quick start Bradford protein assay instruction manual. Bio-Rad Laboratories, Inc.: Hercules, California, 2014.

15. Association of Official Analytical Chemists. In Official Methods of Analysis, 16th ed.; Association of Official Analytical Chemists: Washington, D.C., 1995.

16. Sathe, S. K. Protein solubility and functionality. In Food Proteins and Peptides: Chemistry, Functionality, Interactions, and Commercialization; Hettiarachchy, N. S.; Sato, K.; Marshall, M. R.; Kannan, A., Eds.: CRC Press, Taylor \& Francis Group. LLC.: Boca Raton, Florida, 2012; pp. 95-125.

17. Kristinsson, H.G.; Theodore, A.E.; Demir, N.; Ingadottir, B. A comparative study between acid- and alkali-aided processing and surimi processing for the recovery of proteins from channel catfish muscle. J. Food Sci. 2005, 70, C298-C306.

18. Undeland, I.; Kelleher, S. D.; Hultin, H. O.; McClements, J.; Thongraung, C. Consistency and solubility changes in herring (Clupeaharengus) light muscle homogenates as a function of pH. J. Agric. Food Chem. 2003, 51, 3992-3998.

19. Kannan, A.; Hettiarachchy, N. S.; Sato, K.; Marshall, M. Food proteins and peptides: Structure-function relationship. In Food Proteins and Peptides: Chemistry, Functionality, Interactions, and Commercialization; Hettiarachchy, N. S.; Sato, K.; Marshall, M. R.; Kannan, A., Eds.: CRC Press, Taylor \& Francis Group. LLC.: Boca Raton, Florida, 2012; pp. 49-95. 20. Gordy, W.; Thomas, W. J. O. Electronegativities of the elements. J. Chem. Phys. 1956, 24, 439-444. 
21. Arakawa, T.; Timasheff, S. N. Mechanism of protein salting in and salting out by divalent cation salts: balance between hydration and salt binding? Biochemistry. 1984, 23, 5912-5923. 22. Clarke, R. J.; Lupfert, C. Influence of anions and cations on the dipole potential of phosphatidylcholine vesicles: a basis for the Hofmeister effect. Biophys. J. 1999, 76, 2614-2624. 23. Kumosinski, T. F. Themodynamic linkage and nonlinear regression analysis: a molecular basis for modelling biomolecular processes. Protein salt-induced solubility profiles. In Advances in Food \& Nutrition Research; Kinsella, J. E., Ed.: Academic Press Inc.: San Diego, California, 1990; Vol. 34, pp.301-325.

24. Diyono, I.; Djaeni, I.; Djaeni, M. Improving public salt quality by chemical treatment. J. Coast. Dev. 2002, 5: 111-116.

25. Ali, S.; Azhar, A. S. Determination of thermodynamic parameters from the dissolution of calcium hydroxide in mixed solvent systems by $\mathrm{pH}$-metric method. J. Phys. Chem. Biophys. 2013, 3(2): 1-6.

26. Cawley, J. J. The determination of "apparent" pKa9s Part II. An experiment using very weak acids (pKa's > 11.4). J. Chem. Educ. 1995, 72: 88-90.

27. Liang, Y.; Hultin, H. O. Separation of membranes from acid-solubilized fish muscle proteins with the aid of calcium ions and organic acids. J. Agric. Food Chem. 2005, 53, 3008-3016.

28. Taskaya, L.; Chen, Y.C.; Beamer, S.; Tou, J.C.; Jaczynski, J. Compositional characteristics of materials recovered from whole gutted silver carp (Hypophthalmichthys molitrix) using isoelectrical solubilization/precipitation. J. Agric. Food Chem. 2009, 57, 4259-4266.

29. Taskaya, L.; Chen, Y.C.; Beamer, S.; Jaczynski, J. Texture and colour properties of proteins recovered from whole gutted silver carp (Hypophthalmichthys molitrix) using isoelectric solubilization/precipitation. J. Sci. Food Agric. 2009, 89, 349-358.

30. Kim, Y. S.; Park, J. W.; Choi, Y. J. New approaches for the effective recovery of fish proteins and their physicochemical characteristics. Fisheries Sci. 2003, 69, 1231-1239.

31. Dagher, S.M.; Hultin, H.O.; Liang, Y. Solubility of cod muscle myofibrillar proteins at alkaline pH. J. Aqua Food Product Technical. 2000, 9, 49-59. 
32. Park, J. W. Surimi and fish protein isolate. In Seafood Industry: Species, Products,

Processing, and Safety (2nd Edition); Flick, G. J.; Granata, L. A.; Martin, R. E., Eds.: John Wiley \& Sons: West Sussex, UK, 2012; pp.118-126. 


\section{Figure Captions}

Figure 1. Protein solubility percentages of different alkali solubilization strategies.

Figure 2. Protein concentration mean values separated by processing base to show the effect of solubilization $\mathrm{pH}$.

Figure 3. Lipid concentration mean values separated by processing base to show the effect of solubilization $\mathrm{pH}$.

Figure 4. Protein and lipid recovery yields of different solubilization strategies.

Figure 5. Protein recovery yields of different solubilization strategies processed by different solubilization bases.

Figure 6. Lipid recovery yields of different solubilization strategies processed by different solubilization bases.

Figure 7. Mineral composition ( $\mathrm{Fe}, \mathrm{Mg}, \mathrm{Ca}, \mathrm{P}$, and $\mathrm{Na}$ ) of the isoelectrically recovered protein using different $\mathrm{pH}$ values and bases, initial starting material (ground catfish), and Alaska Pollock surimi. 


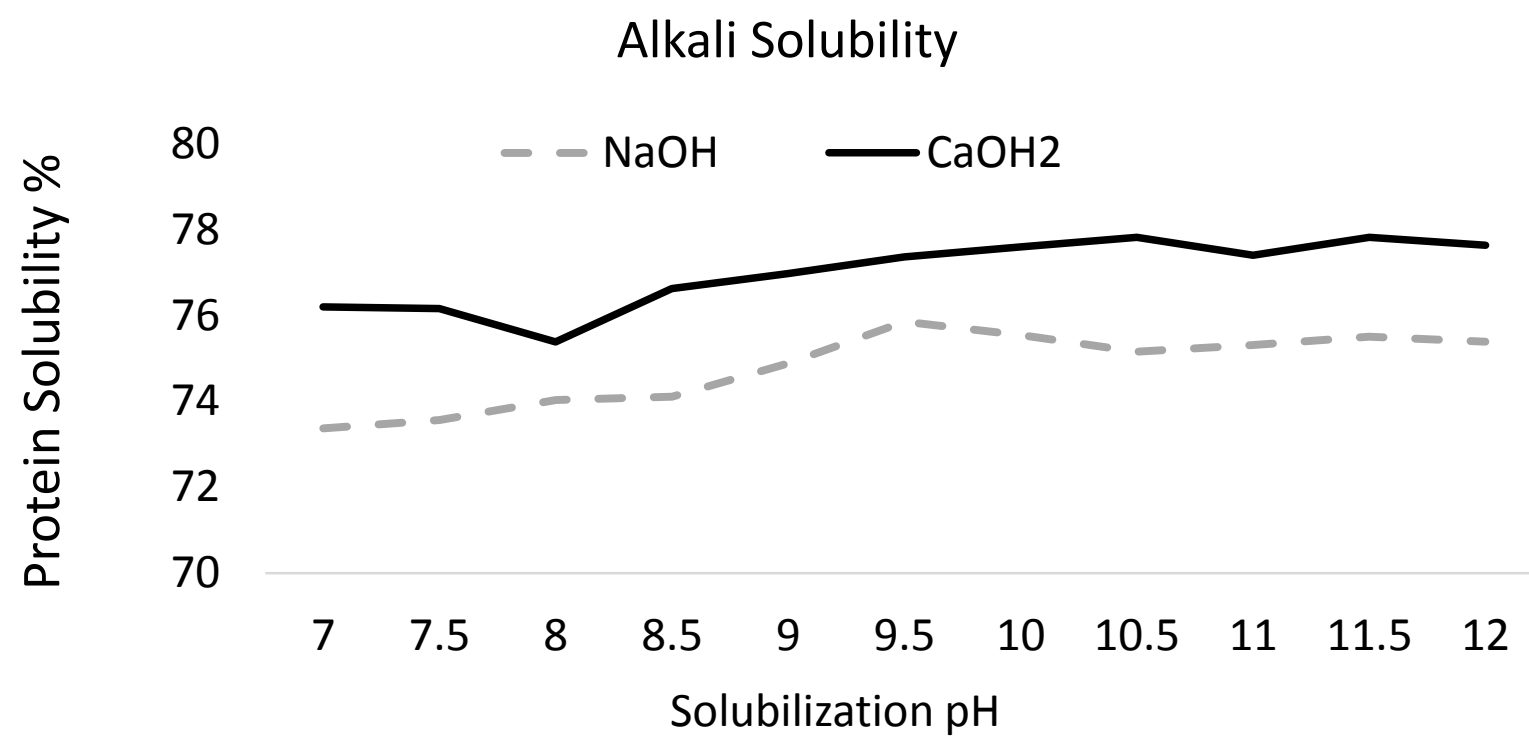

Figure 1. Protein solubility percentages of different alkali solubilization strategies. 

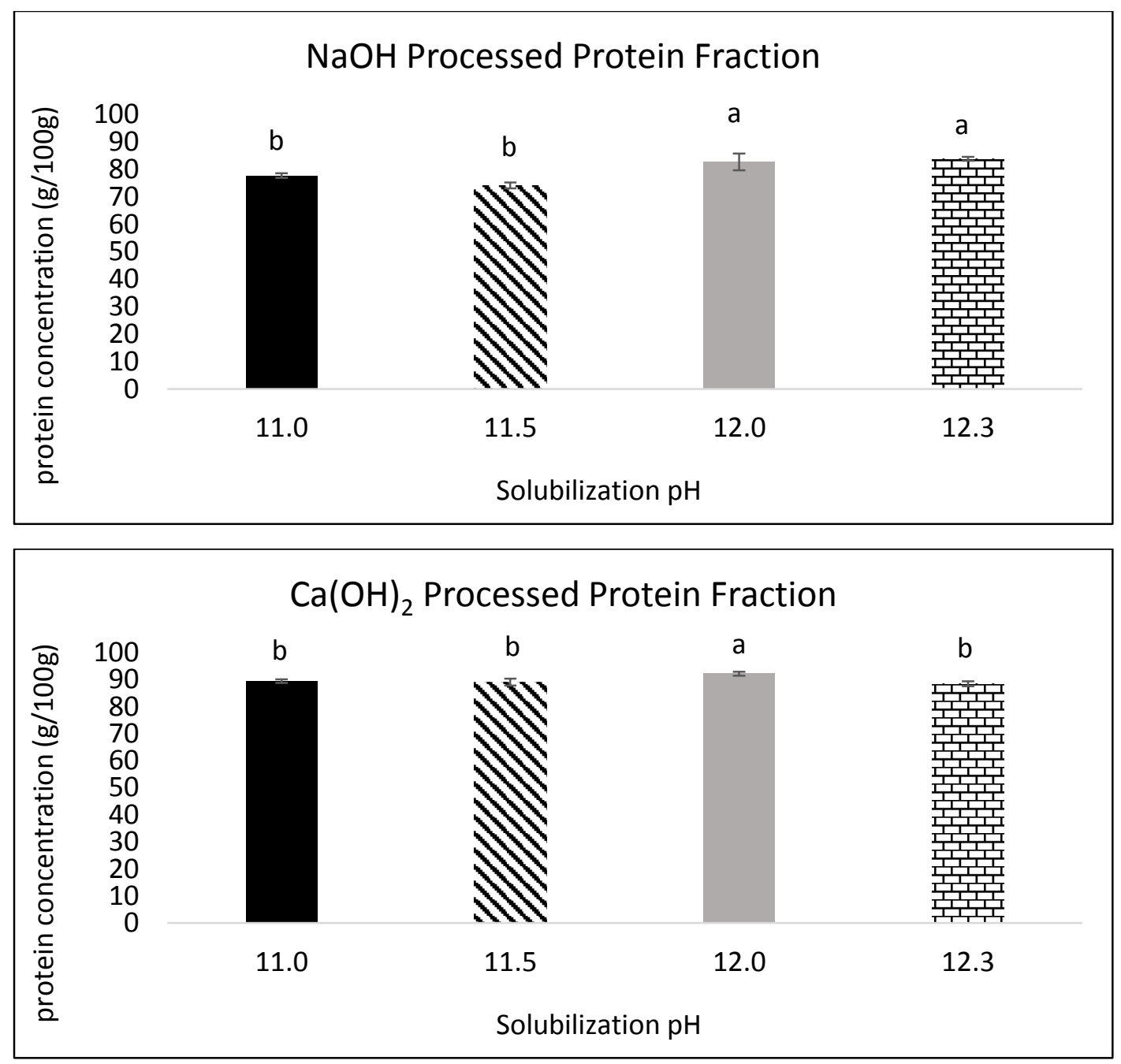

Figure 2. Protein concentration mean values separated by processing base to show the effect of solubilization $\mathrm{pH}$.

a,b,c Mean values with different letters are significantly different (Tukey's honestly significant difference test, $\mathrm{p}<0.05)$. 

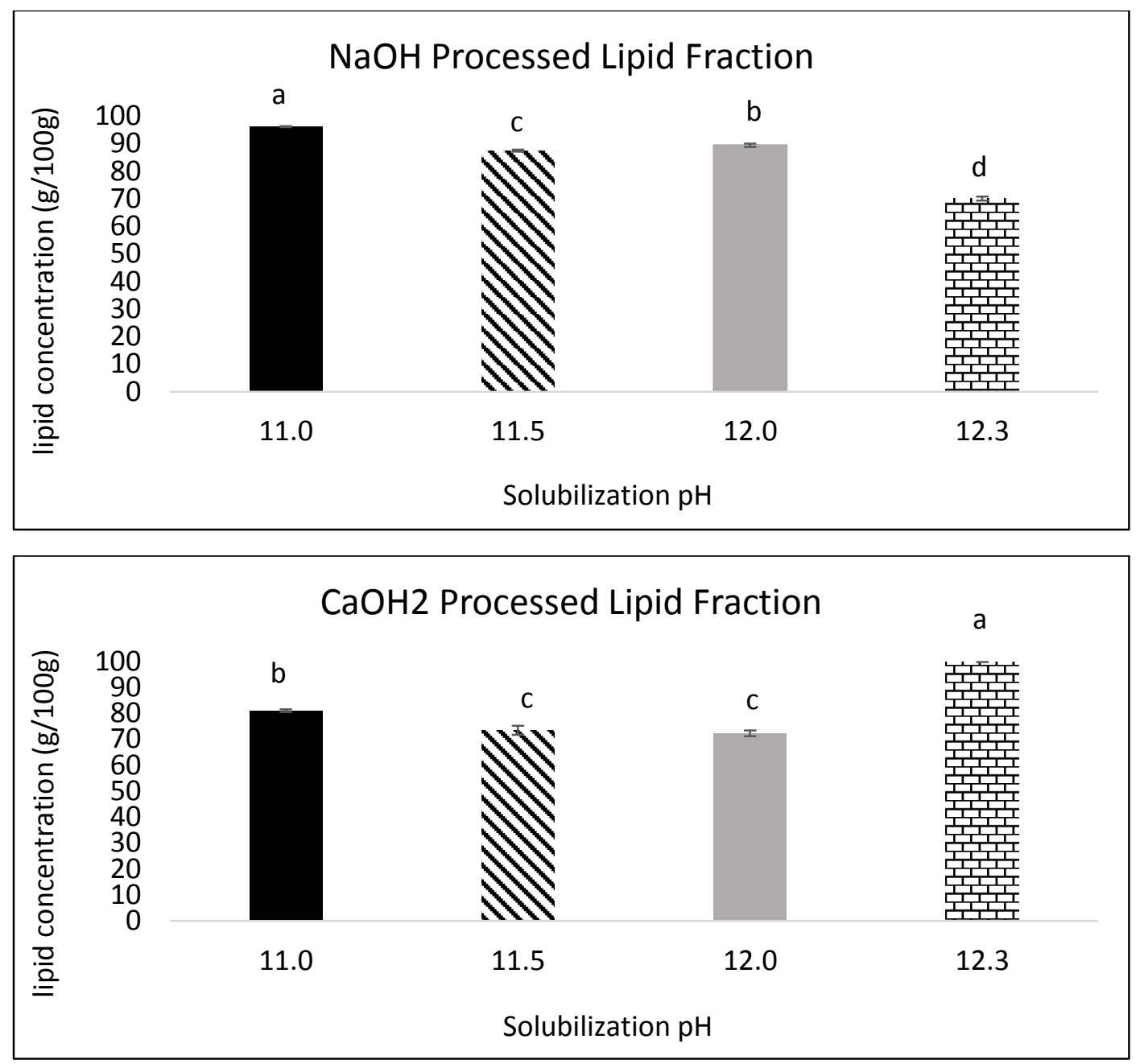

Figure 3. Lipid concentration mean values separated by processing base to show the effect of solubilization $\mathrm{pH}$.

a,b,c Mean values with different letters are significantly different (Tukey's honestly significant difference test, $\mathrm{p}<0.05)$. 


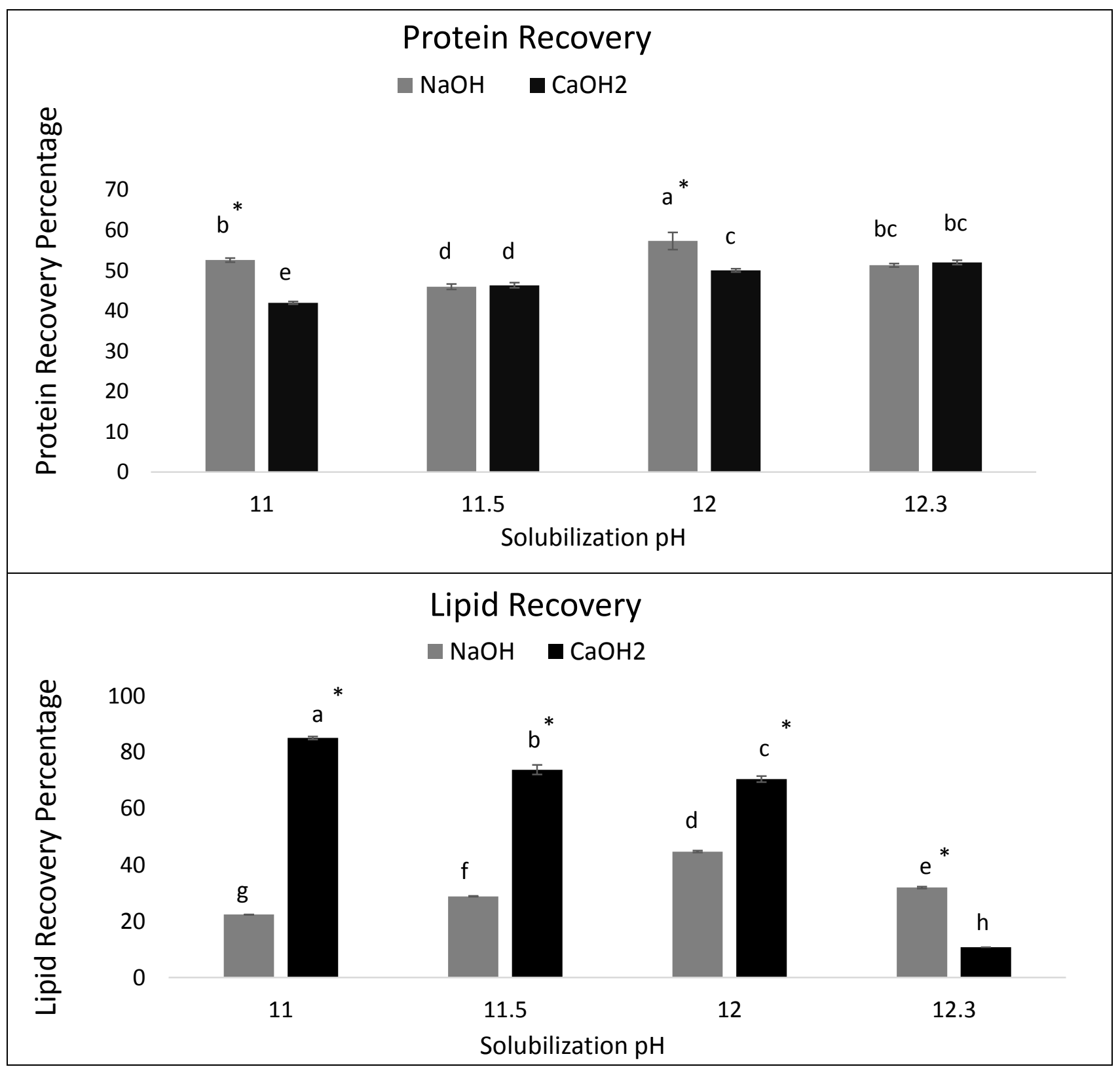

Figure 4. Protein and lipid recovery yields of different solubilization strategies.

a,b,c,d,e,f,g Mean values with different letters are significantly different (Tukey’s honestly significant difference test, $\mathrm{p}<0.05)$.

Significant differences between $\mathrm{NaOH}$ and $\mathrm{Ca}(\mathrm{OH})_{2}$ with in the same solubilization $\mathrm{pH}$ (one way ANOVA test, $\mathrm{p}<0.05)$ are indicated with an *. 

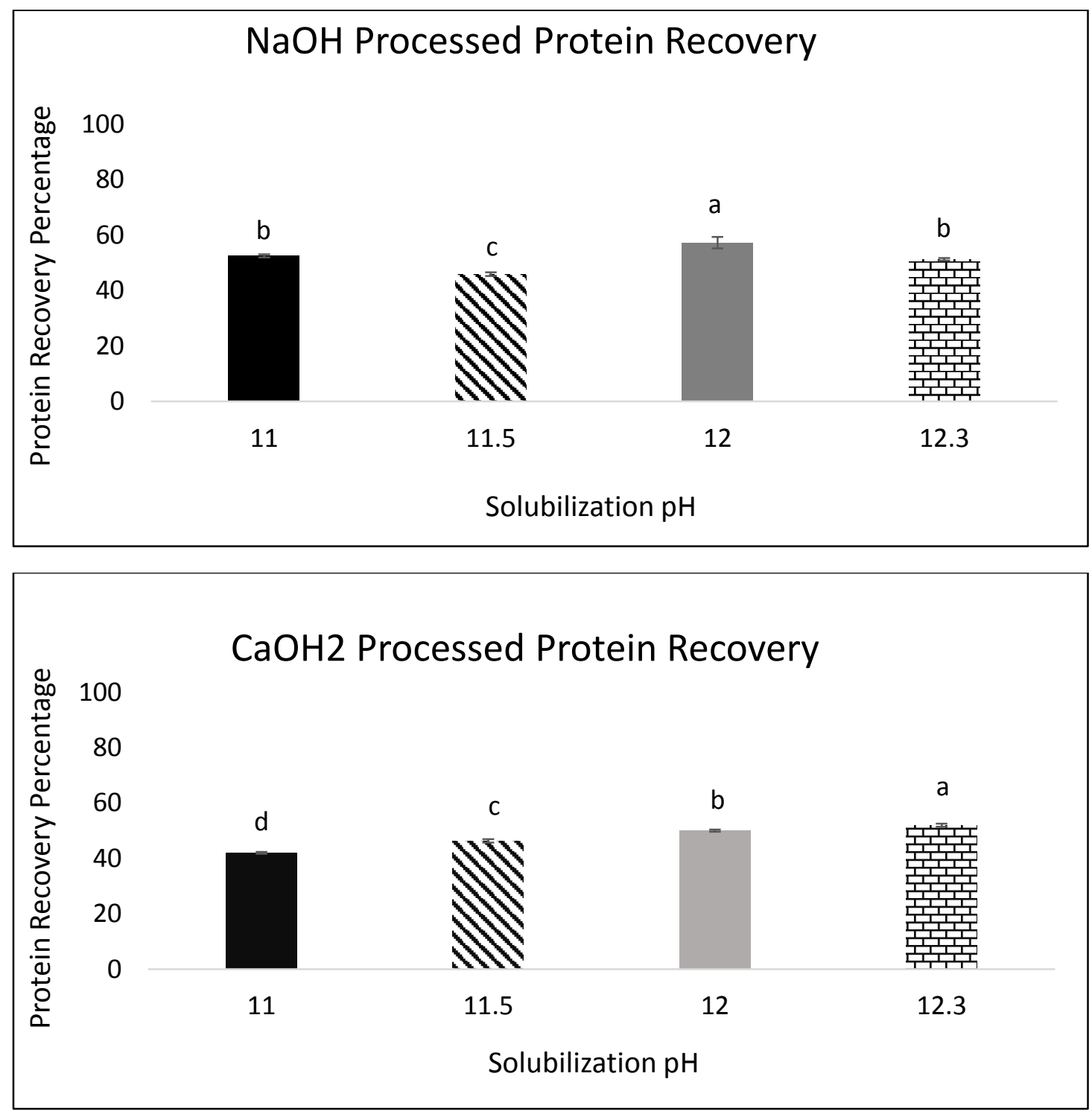

Figure 5. Protein recovery yields of different solubilization strategies processed by different solubilization bases.

a,b,c,d Mean values with different letters are significantly different (Tukey's honestly significant difference test, $\mathrm{p}<0.05)$. 

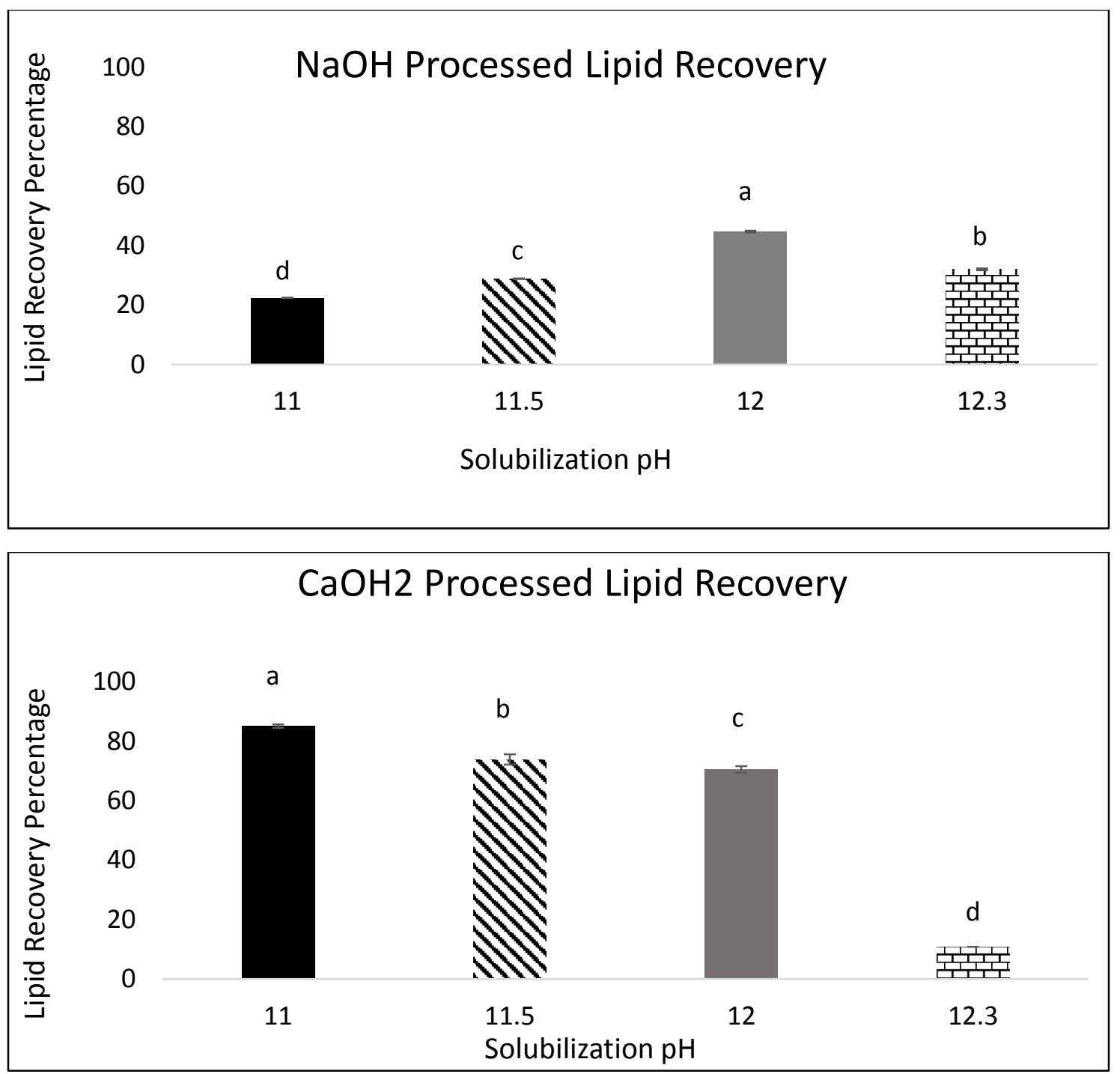

Figure 6. Lipid recovery yields of different solubilization strategies processed by different solubilization bases.

a,b,c,d Mean values with different letters are significantly different (Tukey's honestly significant difference test, $\mathrm{p}<0.05$ ). 


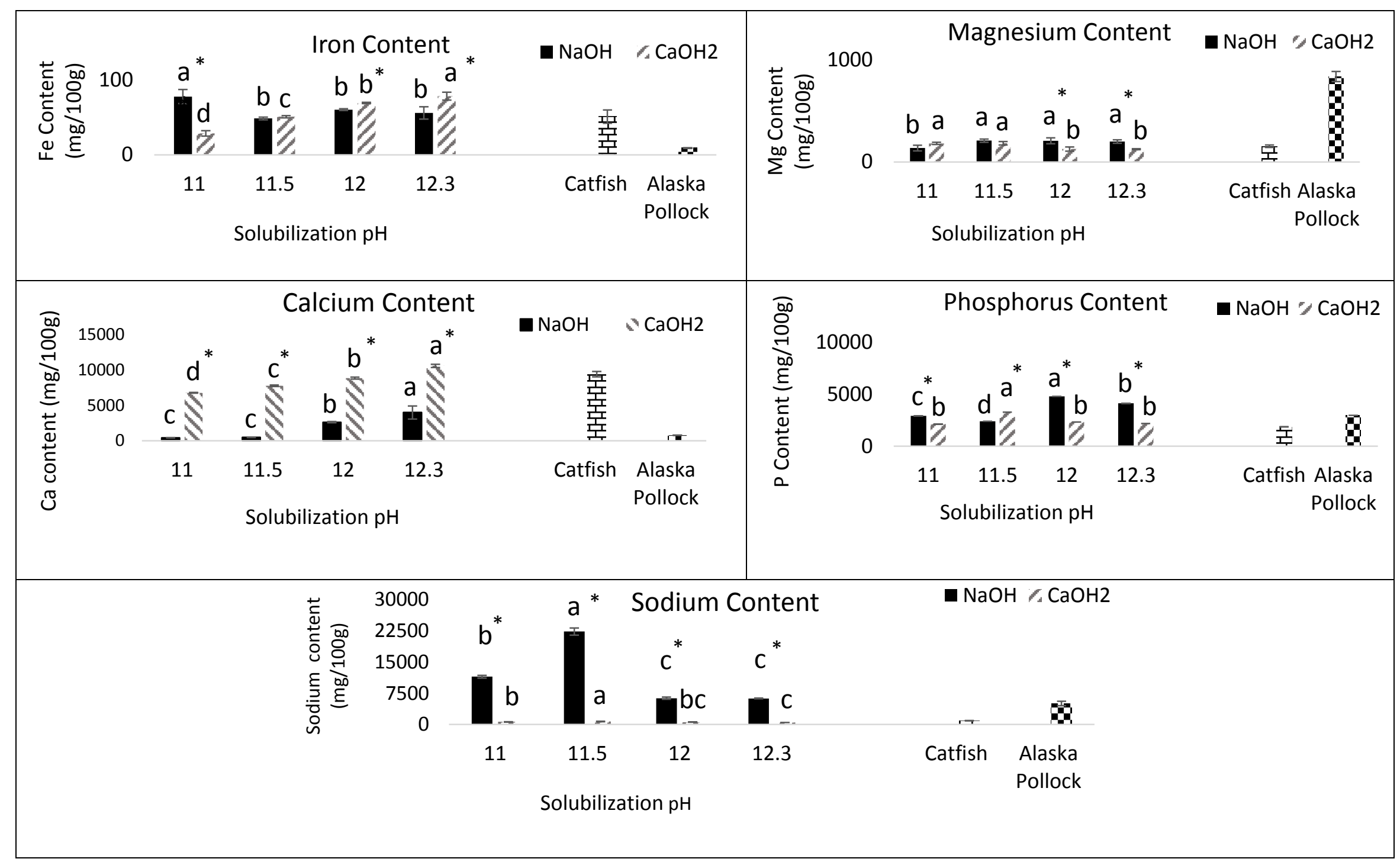

Figure 7. Mineral composition (Fe, $\mathrm{Mg}, \mathrm{Ca}, \mathrm{P}$, and $\mathrm{Na}$ ) of the recovered protein using different solubilization strategies, initial starting material (ground catfish), and Alaska Pollock surimi. a,b,c,d Mean values of recovered protein with different letters are significantly different (Tukey's honestly significant difference test, $\mathrm{p}<0.05)$. $*$ indicates significant differences $(\mathrm{p}<0.05)$ between processing bases within the same solubilization $\mathrm{pH}$. 
Table 1. Proximate composition (g/100g, dry basis) of the recovered protein and lipid fractions using different solubilization strategies and initial starting material (ground catfish).

\begin{tabular}{|c|c|c|c|c|}
\hline \multicolumn{5}{|c|}{ Recovered Protein Fraction } \\
\hline Solubilization $\mathrm{pH}$ & Base & Ash (g/100g) & Lipid (g/100g) & Protein $(\mathrm{g} / 100 \mathrm{~g})$ \\
\hline 11 & $\mathrm{NaOH}$ & $8.50 \pm 0.25 a$ & $13.53 \pm 0.66 \mathrm{ab}$ & $78.45 \pm 0.79 c$ \\
\hline 11 & $\mathrm{Ca}(\mathrm{OH})_{2}$ & $2.11 \pm 0.20 \mathrm{e}$ & $8.21 \pm 0.77 \mathrm{c}$ & $89.42 \pm 0.68 \mathrm{a}$ \\
\hline 11.5 & $\mathrm{NaOH}$ & $9.04 \pm 0.23 a$ & $16.69 \pm 0.99 \mathrm{a}$ & $74.23 \pm 1.07 \mathrm{c}$ \\
\hline 11.5 & $\mathrm{Ca}(\mathrm{OH})_{2}$ & $3.01 \pm 0.06 \mathrm{~d}$ & $7.81 \pm 1.28 \mathrm{~cd}$ & $89.04 \pm 1.26 \mathrm{a}$ \\
\hline 12 & $\mathrm{NaOH}$ & $3.51 \pm 0.26 \mathrm{~cd}$ & $13.56 \pm 3.10 \mathrm{ab}$ & $82.74 \pm 3.05 b$ \\
\hline 12 & $\mathrm{Ca}(\mathrm{OH})_{2}$ & $3.76 \pm 0.31 \mathrm{c}$ & $3.91 \pm 0.77 d$ & $92.14 \pm 0.76 \mathrm{a}$ \\
\hline 12.3 & $\mathrm{NaOH}$ & $3.53 \pm 0.14 \mathrm{~cd}$ & $12.50 \pm 0.62 b$ & $83.82 \pm 0.72 b$ \\
\hline 12.3 & $\mathrm{Ca}(\mathrm{OH})_{2}$ & $4.63 \pm 0.37 b$ & $6.87 \pm 1.04 \mathrm{~cd}$ & $88.42 \pm 0.94 a$ \\
\hline \multicolumn{2}{|c|}{ Initial, Ground Catfish } & $8.00 \pm 0.74$ & $38.18 \pm 3.22$ & $53.71 \pm 3.32$ \\
\hline & \multicolumn{4}{|c|}{ Recovered Lipid Fraction } \\
\hline Solubilization $\mathrm{pH}$ & Base & Ash (g/100g) & Lipid (g/100g) & Protein $(\mathrm{g} / 100 \mathrm{~g})$ \\
\hline 11.0 & $\mathrm{NaOH}$ & $0.56 \pm 0.10 c$ & $96.21 \pm 0.17 b$ & $3.20 \pm 0.09 c$ \\
\hline 11.0 & $\mathrm{Ca}(\mathrm{OH})_{2}$ & $7.56 \pm 0.24 a b$ & $80.98 \pm 0.52 d$ & $10.62 \pm 0.85 b$ \\
\hline 11.5 & $\mathrm{NaOH}$ & $1.53 \pm 0.12 c$ & $87.48 \pm 0.35 c$ & $10.89 \pm 0.23 b$ \\
\hline 11.5 & $\mathrm{Ca}(\mathrm{OH})_{2}$ & $5.03 \pm 1.39 \mathrm{~b}$ & $73.42 \pm 1.72 \mathrm{e}$ & $21.08 \pm 0.80 a$ \\
\hline 12.0 & $\mathrm{NaOH}$ & $1.53 \pm 0.05 c$ & $89.42 \pm 0.66 \mathrm{c}$ & $9.01 \pm 0.67$ b \\
\hline 12.0 & $\mathrm{Ca}(\mathrm{OH})_{2}$ & $8.16 \pm 2.38 a$ & $72.22 \pm 1.08$ ef & $19.48 \pm 1.43 \mathrm{a}$ \\
\hline 12.3 & $\mathrm{NaOH}$ & $8.96 \pm 0.21 \mathrm{a}$ & $70.02 \pm 0.73 f$ & $20.96 \pm 0.56 a$ \\
\hline 12.3 & $\mathrm{Ca}(\mathrm{OH})_{2}$ & $0.08 \pm 0.009 c$ & $99.68 \pm 0.02 \mathrm{a}$ & $0.05 \pm 0.008 d$ \\
\hline
\end{tabular}

$\overline{\mathrm{a}, \mathrm{b}, \mathrm{c}, \mathrm{d}, \mathrm{e}}$ Mean values in a column with different letters are significantly different (Tukey's honestly significant difference test, $\mathrm{p}<0.05$ ).

Bold values indicate significant differences between $\mathrm{NaOH}$ and $\mathrm{Ca}(\mathrm{OH})_{2}$ within the same solubilization $\mathrm{pH}$ (one way ANOVA test, $\mathrm{p}<0.05$ ). 
Table 2. Mineral composition (Fe, $\mathrm{Mg}, \mathrm{Ca}, \mathrm{P}$, and $\mathrm{Na}$ ) of the recovered protein using different $\mathrm{pH}$ shift treatments.

\begin{tabular}{|c|c|c|c|c|c|c|}
\hline Solubilization $\mathrm{pH}$ & Base & $\mathrm{Fe}(\mathrm{mg} / \mathrm{mL})$ & $\mathrm{Mg}(\mathrm{mg} / \mathrm{mL})$ & $\mathrm{Ca}(\mathrm{mg} / \mathrm{mL})$ & $\mathrm{P}(\mathrm{mg} / \mathrm{mL})$ & $\mathrm{Na}(\mathrm{mg} / \mathrm{mL})$ \\
\hline 11.0 & $\mathrm{NaOH}$ & $77.89 \pm 9.40 a$ & $135.16 \pm 26.89 \mathrm{bc}$ & $250.05 \pm 11.11 \mathrm{~g}$ & $2901.85 \pm 57.16 \mathrm{~d}$ & $11469.80 \pm 337.97 \mathrm{~b}$ \\
\hline 11.0 & $\mathrm{Ca}(\mathrm{OH}) 2$ & $28.64 \pm 3.53 d$ & $180.85 \pm 11.89 a b$ & $6764.28 \pm 59.72 \mathrm{~d}$ & $2114.85 \pm 55.85 \mathrm{e}$ & $618.90 \pm 17.78 \mathrm{~d}$ \\
\hline 11.5 & $\mathrm{NaOH}$ & $48.66 \pm 1.93 \mathrm{c}$ & $207.90 \pm 15.22 \mathrm{a}$ & $474.80 \pm 8.00 \mathrm{~g}$ & $2395.46 \pm 32.60 \mathrm{e}$ & $22311.97 \pm 880.88 a$ \\
\hline 11.5 & $\mathrm{Ca}(\mathrm{OH}) 2$ & $51.01 \pm 1.57 \mathrm{c}$ & $181.41 \pm 16.57 \mathrm{ab}$ & $7753.40 \pm 99.01 \mathrm{c}$ & $3265.87 \pm 215.20 \mathrm{c}$ & $722.64 \pm 49.51 \mathrm{~d}$ \\
\hline 12.0 & $\mathrm{NaOH}$ & $60.44 \pm 1.18$ bc & $205.87 \pm 29.13$ a & $2621.38 \pm 80.21 \mathrm{f}$ & $4786.68 \pm 123.09$ a & $6295.01 \pm 259.28 \mathrm{c}$ \\
\hline 12.0 & $\mathrm{Ca}(\mathrm{OH}) 2$ & $69.43 \pm 0.95 a b$ & $125.62 \pm 21.32 \mathrm{c}$ & $8853.37 \pm 139.27$ b & $2317.30 \pm 138.58 \mathrm{e}$ & $552.11 \pm 6.97 d$ \\
\hline 12.3 & $\mathrm{NaOH}$ & $56.18 \pm 8.23 \mathrm{bc}$ & $198.53 \pm 16.72$ a & $3993.14 \pm 933.28 \mathrm{e}$ & $4111.81 \pm 102.00 \mathrm{~b}$ & $6231.78 \pm 101.76 \mathrm{c}$ \\
\hline 12.3 & $\mathrm{Ca}(\mathrm{OH}) 2$ & $78.54 \pm 5.36 \mathrm{a}$ & $124.39 \pm 5.33 c$ & $10568.44 \pm 238.68$ a & $2172.93 \pm 111.10 \mathrm{e}$ & $491.24 \pm 2.21 \mathrm{~d}$ \\
\hline
\end{tabular}

$\overline{\mathrm{a}, \mathrm{b}, \mathrm{c}, \mathrm{d}, \mathrm{e}, \mathrm{f}, \mathrm{g}}$ Mean values in a column with different letters are significantly different (Tukey's honestly significant difference test, $\mathrm{p}<0.05)$.

Bold values indicate significant differences between $\mathrm{NaOH}$ and $\mathrm{Ca}(\mathrm{OH})_{2}$ within the same solubilization pH (one way ANOVA test, $\mathrm{p}<0.05)$. 
Table 3. Mineral composition ( $\mathrm{Fe}, \mathrm{Mg}, \mathrm{Ca}, \mathrm{P}$, and $\mathrm{Na}$ ) of the recovered protein using different $\mathrm{pH}$ shift treatments, initial starting material (ground black bullhead catfish), and Alaska Pollock surimi.

\begin{tabular}{|c|c|c|c|c|c|c|}
\hline Solubilization $\mathrm{pH}$ & Base & $\mathrm{Fe}(\mathrm{mg} / \mathrm{mL})$ & $\mathrm{Mg}(\mathrm{mg} / \mathrm{mL})$ & $\mathrm{Ca}(\mathrm{mg} / \mathrm{mL})$ & $\mathrm{P}(\mathrm{mg} / \mathrm{mL})$ & $\mathrm{Na}(\mathrm{mg} / \mathrm{mL})$ \\
\hline 11.0 & $\mathrm{NaOH}$ & $77.89 \pm 9.40 \mathrm{a}, \mathrm{v}$ & $135.16 \pm 26.89 \mathrm{~cd}, \mathrm{yz}$ & $250.05 \pm 11.11 \mathrm{f}, \mathrm{z}$ & $2901.85 \pm 57.16 \mathrm{~d}, \mathrm{y}$ & $11469.80 \pm 337.97 \mathrm{~b}, w$ \\
\hline 11.0 & $\mathrm{Ca}(\mathrm{OH}) 2$ & $28.64 \pm 3.53 \mathrm{~d}, \mathrm{y}$ & $180.85 \pm 11.89 a b c, x y z$ & $6764.28 \pm 59.72 \mathrm{c}, \mathrm{w}$ & $2114.85 \pm 55.85$ ef,z & $618.90 \pm 17.78 d, z$ \\
\hline 11.5 & $\mathrm{NaOH}$ & $48.66 \pm 1.93 c, x$ & $207.90 \pm 15.22 a, x$ & $474.80 \pm 8.00 \mathrm{f}, \mathrm{z}$ & $2395.46 \pm 32.60 \mathrm{e}, \mathrm{z}$ & $22311.97 \pm 880.88 \mathrm{a}, \mathrm{v}$ \\
\hline 11.5 & $\mathrm{Ca}(\mathrm{OH}) 2$ & $51.01 \pm 1.57$ c,x & $181.41 \pm 16.57$ abc,xyz & $7753.40 \pm 99.01 \mathrm{c,v}$ & $3265.87 \pm 215.20 c, x$ & $722.64 \pm 49.51 \mathrm{~d}, \mathrm{z}$ \\
\hline 12.0 & $\mathrm{NaOH}$ & $60.44 \pm 1.18$ bc,wx & $205.87 \pm 29.13$ ab,xy & $2621.38 \pm 80.21 \mathrm{e}, \mathrm{y}$ & $4786.68 \pm 123.09 a, v$ & $6295.01 \pm 259.28 c, x$ \\
\hline 12.0 & $\mathrm{Ca}(\mathrm{OH}) 2$ & $69.43 \pm 0.95 a b, v w$ & $125.62 \pm 21.32 \mathrm{~d}, \mathrm{z}$ & $8853.37 \pm 139.27 b, u$ & $2317.30 \pm 138.58 \mathrm{e}, \mathrm{z}$ & $552.11 \pm 6.97 \mathrm{~d}, \mathrm{z}$ \\
\hline 12.3 & $\mathrm{NaOH}$ & $56.18 \pm 8.23$ bc,wx & $198.53 \pm 16.72 a b, x y$ & $3993.14 \pm 933.28 d, x$ & $4111.81 \pm 102.00 \mathrm{~b}, \mathrm{w}$ & $6231.78 \pm 101.76 c, x$ \\
\hline 12.3 & $\mathrm{Ca}(\mathrm{OH}) 2$ & $78.54 \pm 5.36 \mathrm{a}, \mathrm{v}$ & $124.39 \pm 5.33 d, z$ & $10568.44 \pm 238.68 \mathrm{a}, \mathrm{u}$ & $2172.93 \pm 111.10 \mathrm{e}, \mathrm{z}$ & $491.24 \pm 2.21 \mathrm{~d}, \mathrm{z}$ \\
\hline \multicolumn{2}{|c|}{ Ground Catfish } & $51.11 \pm 8.85 \mathrm{c}$ & $153.23 \pm 12.26 \mathrm{bcd}$ & $9399.43 \pm 394.15 \mathrm{~b}$ & $1850.30 \pm 44.25 \mathrm{f}$ & $922.19 \pm 15.83 \mathrm{~d}$ \\
\hline \multicolumn{2}{|c|}{ Alaska Pollock surimi } & $9.09 \pm 0.52 z$ & $834.36 \pm 50.18$ w & $778.14 \pm 26.67$ z & $2947.61 \pm 183.66$ xy & $5024.73 \pm 537.66$ y \\
\hline
\end{tabular}

a,b,c,d,e,f Mean values of protein fractions recovered using $\mathrm{pH}$ shift treatments and ground catfish in a column with different letters are significantly different (Tukey's honestly significant difference test, $\mathrm{p}<0.05$ ).

$\mathrm{t}, \mathrm{u}, \mathrm{v}, \mathrm{w}, \mathrm{x}, \mathrm{y}, \mathrm{z}$ Mean values of protein fractions recovered using $\mathrm{pH}$ shift treatments and Alaska Pollock surimi in a column with different letters are significantly different (Tukey's honestly significant difference test, $\mathrm{p}<0.05$ ). 


\section{CHAPTER 2}

\section{Calcium Enhanced Protein Recovery from Black Bullhead Catfish Using Organic Acids}

\section{Abstract}

Isoelectric solubilization and precipitation (ISP), a protein extraction method utilizing $\mathrm{pH}$ shifts to solubilize and then precipitate protein, was applied to black bullhead catfish (Ameiurus melas). The efficacy of protein and lipid recovery was investigated at different solubilization $\mathrm{pH}$ values $(11.0,11.5,12.0$, and 12.3) using either sodium hydroxide $(\mathrm{NaOH})$ or calcium hydroxide $\left(\mathrm{Ca}(\mathrm{OH})_{2}\right)$ and precipitation at the isoelectric point of protein $(\mathrm{pH} 5.5)$ using either lactic acid (LA) or acetic acid (AA). Protein, lipid, and ash content of the recovered protein and lipid fractions were analyzed and recovery yields were calculated. Mineral profiles of recovered protein fractions were compared between different solubilization strategies. Solubilization using $\mathrm{Ca}(\mathrm{OH})_{2}$ increased $(\mathrm{p}<0.05)$ protein concentration in the recovered protein fraction from 64-87 $\mathrm{g} / 100$ to $88-92 \mathrm{~g} / 100 \mathrm{~g}$ compared to $\mathrm{NaOH}$ processing regardless of precipitation acid. Protein recovery yields on the other hand ranged from $42-59 \mathrm{~g} / 100 \mathrm{~g}$. Solubilization using $\mathrm{Ca}(\mathrm{OH})_{2}$ resulted in a protein fraction with increased calcium and less sodium $(\mathrm{p}<0.05)$ compared to $\mathrm{NaOH}$ processing. Overall, organic acids provided similar protein precipitation and recovery yields as the traditionally used hydrochloric acid during $\mathrm{pH}$ shift processing.

Keywords: Calcium hydroxide, lactic acid, acetic acid, sodium hydroxide, $\mathrm{pH}$ shift, protein recovery, protein solubility, calcium 


\section{Introduction}

Black bullhead catfish (Ameiurus melas) are abundant and often found in aquatic habitats in the US that are utilized for recreational fishing ${ }^{1}$. Due to its ability to overpopulate a pond or a fish farm and its interference with the bass-bluegill predator: prey relationship, bullheads are labeled as unwanted fish ${ }^{2}$. Black bullhead catfish can survive in conditions like low oxygen that are not suitable for more desirable fish such as bass ${ }^{1,2}$. Recreational fishing ponds are usually stocked with bass, channel catfish, bluegill, and grass carp; whereas, appearance of black bullheads are an issue for pond management ${ }^{1,2}$. The value of these types of unwanted fish species may be increased by extracting their high quality protein that may be repurposed to help ease issues associated with protein malnutrition.

Isoelectric solubilization and precipitation (ISP) is a protein recovery method where underutilized fish species, processing byproducts, or any animal protein source can be used as the starting material ${ }^{3-5}$. This technique involves exposing the initial protein source to extremely acidic ( $\mathrm{pH} 2.0-3.0)$ or alkali $(\mathrm{pH} 10.5-12.5)$ conditions in order to increase protein-water interactions for protein solubilization ${ }^{3,6}$. The solubilized protein is then separated from water soluble lipids like membrane lipids and insolubles such as skins, bones, and scales. Upon removal of the lipids and insolubles, solubilized protein in the form of an aqueous solution is precipitated using a processing acid or a base to bring the $\mathrm{pH}$ of the solution to the isoelectric point of $\mathrm{pH} 5.5$ where the net charge is 0 driving protein-protein interactions causing aggregation and consequently, precipitation ${ }^{3}$. The recovered protein preserves its functionality and thus may be further processed into reconstructed food products such as fish gels, sausages, or nuggets ${ }^{7-9}$. It may further be used to enhance the amount of protein in food products as a healthier alternative. 
Alkali solubilization where protein is subjected to high $\mathrm{pH}$ using a processing base negatively charges the protein; therefore, increasing protein-protein repulsive forces and making proteins water soluble ${ }^{3}$. Compared to acidic solubilization, alkali solubilization will yield greater protein recovery while inducing less conformational changes on the protein ${ }^{6}$. Alkali solubilization also yields a protein fraction with higher essential amino acid amounts in comparison to acidic solubilization strategies ${ }^{10}$. On the other hand, protein recovery using the traditionally used base sodium hydroxide $(\mathrm{NaOH})$ during ISP will significantly increase the amount of sodium in the recovered protein fraction which is associated with the risk of hypertension and cardiovascular diseases ${ }^{6,11,12}$. Replacing $\mathrm{NaOH}$ with calcium hydroxide $\left(\mathrm{Ca}(\mathrm{OH})_{2}\right)$, a widely used calcium fortification agent, during alkali solubilization will yield calcium fortified protein which would be beneficial for sustaining bone strength against osteoporosis with the added advantage of containing lower sodium levels upon recovery ${ }^{11,13}$. Moreover, $\mathrm{Ca}(\mathrm{OH})_{2}$ is more effective protein solubilizing base compared to $\mathrm{NaOH}$ yielding a greater protein concentration in the recovered protein fraction and protein recovery yields using either $\mathrm{NaOH}$ or $\mathrm{Ca}(\mathrm{OH})_{2}$ showed similar ranges around $44-59 \mathrm{~g} / 100 \mathrm{~g}{ }^{11}$.

There are four major desired outcomes of ISP application; high protein recovery yield for economic feasibility, little loss of protein functionality, high nutritional value, and removal of fishy smell, muddy taste or off color especially when dark skinned or darker flesh sources are used. Protein recovery yield is mainly affected by the ionic strength of the solution, solubilization $\mathrm{pH}$, and the efficacy of the processing base and acid on solubilizing and then precipitating the protein. As mentioned previously, $\mathrm{Ca}(\mathrm{OH})_{2}$ displayed high protein solubility properties during alkali solubilization; however, the recovery yields were not greater than previously reported results using $\mathrm{NaOH}$ and $\mathrm{HCl}$ during alkali processing and precipitation of 
protein fractions ${ }^{11}$. Therefore, protein recovery yields may be improved by replacing the commonly used protein precipitation acid, hydrochloric acid $(\mathrm{HCl})$ with other types of acids to aid protein precipitation. Processing acids affect precipitation of proteins and organic acids such as acetic acid (AA) and a 1:1 combination of formic and lactic acid were shown to be effective in protein precipitation with the additional benefit of controlling microbial contamination ${ }^{6,14-17}$. Moreover, organic acids may be more effective in removing impurities (such as lipids, scales, and bones) from the protein fraction that would otherwise adversely affect functionality, storage life, color and smell of the food product while inducing less protein denaturation during alkali processing of fish protein due to their weaker nature compared to the traditionally used $\mathrm{HCl}^{6}$.

Lactate salts are commonly used in meat products made from pork and beef as a microbial safety measure and for color and sensory property preservation during storage ${ }^{18-20}$. Using lactic acid (LA) as the processing acid during ISP may provide similar benefits of reducing bacterial contamination and preserving the native structure of protein which is very important for functionality measures. Therefore, LA which is a generally recognized as safe ingredient by the U.S. Food and Drug Administration with no limitations when used in food products, was selected as one of the processing acids in this study ${ }^{21}$. Acetic acid, another organic acid successfully used in meat and poultry products for pathogen growth control and as a meat marination ingredient was shown to tenderize, flavor and increase water holding capacity of meat fibers $^{22}$. Using AA during ISP process was previously shown to yield higher protein concentration in the recovered protein fraction possibly due to its ability to precipitate protein at a higher rate compared to LA $^{6}$. Therefore, the aim of this study was to investigate the compositional (protein, lipid, and ash) differences in recovered protein and lipid fractions when either $\mathrm{Ca}(\mathrm{OH})_{2}$ or $\mathrm{NaOH}$ was used to solubilize protein at four different alkali $\mathrm{pH}$ values (11.0, 
$11.5,12.0,12.3)$ and precipitation was achieved using either LA or AA at $\mathrm{pH}$ 5.5. The protein and lipid recovery yields, and the mineral contents of the recovered proteins were also measured and compared to assess the differences when different solubilization and precipitation strategies are applied during ISP processing.

2. Materials and Methods

2.1. Preparation of ground catfish

Freshly caught, gutted black bullhead catfish (Ameiurus melas) was processed into ground fish at the meats processing laboratory at West Virginia University. The fish, caught with a net at a fish hatchery (Dog Wood Lake, Morgantown WV) was placed on ice in coolers containing carbon monoxide and transported to the laboratory within $1 \mathrm{~h}$. All fish processing equipment was sanitized prior to fish handling. Upon arrival at the laboratory, the fish were taken out of the containers, washed under running tap water, gutted, and washed one last time under running tap water. Fish was then ground twice using a meat grinder (Hobart Model 4146, Troy, OH, USA) into a thick paste using a coarse grinder plate in order to dispense big chunks of fish, head and bones. The ground fish was stored in a $-20{ }^{\circ} \mathrm{C}$ freezer overnight inside capped steel trays for avoiding thermal denaturation and microbiological contamination associated with the rise in heat due to grinding process. Fish was chilled and not frozen at the $-20{ }^{\circ} \mathrm{C}$ freezer; therefore, the coarsely ground fish was further reduced in size by fine grinding using a finer grinder plate. The extra step of fine grinding decreased particle size, and allowed for a more homogenous mixture of heads, bones, and the fish flesh. The finely ground fish was then individually weighed (500 g) into freezer bags (Ziplock Freezer Bags, S.C. Johnson \& Son, Inc., Racine, Wis., USA) and vacuum packaged (Ultravac KOCH Packaging, KOCH Supplies Inc., 
Kansas City, MO, USA). In order to avoid thermal denaturation, the fish packages were stored at $-80^{\circ} \mathrm{C}$ until further analysis up to a maximum of 16 days.

2.2. Protein separation using isoelectric solubilization and precipitation (ISP)

Isoelectric solubilization and precipitation was applied to thawed $\left(4^{\circ} \mathrm{C}\right.$ for $\left.24-48 \mathrm{~h}\right)$, ground catfish $(500 \mathrm{~g})^{3}$. A dilution ratio of 1:6 (fish: destilled/deionized water) was used and the initial $\mathrm{pH}$ of the mixture was determined as 6.7 using a calibrated $\mathrm{pH} / \mathrm{ion}$ analyzer (Oakton, Eutech Instruments; Singapore). Alkali protein solubilization was achieved by adding either 1 mol L $\mathrm{L}^{-1}$ calcium hydroxide $\left(\mathrm{Ca}(\mathrm{OH})_{2}\right)$ or $10 \mathrm{~mol} \mathrm{~L}^{-1}$ sodium hydroxide $(\mathrm{NaOH})$ to raise to the $\mathrm{pH}$ to the tested values $(11.0,11.5,12.0$ or 12.3$)$. The mixture was homogenized using a laboratory grade, sanitized homogenizer (PowerGen 700, Fisher Scientific, Pittsburgh, PA) for $15 \mathrm{~min}$ and was continued for an extra 10 min after the target $\mathrm{pH}$ was reached to allow for better protein solubilization. The mixture was then transferred to centrifuge bottles and centrifuged at 10,000 x G for $15 \mathrm{~min}$ at $4^{\circ} \mathrm{C}$ (Sorvall RC-SB Refrigerated Superspeed Centrifuge, Du Pont, Wilmington, DE, USA) to separate water soluble lipids and insoluble such as scales, bones and skin from the solubilized protein fraction ${ }^{3}$. Following centrifugation, lipids having formed a layer at the top of the centrifuge bottle was collected using a steel spatula into a freezer cup. The solubilized protein in aqueous form was filtered through a cheese cloth into a glass beaker. The insoluble that were left as a pellet at the bottom of the centrifuge bottles were discarded. The $\mathrm{pH}$ of the protein solution was brought down to the protein isoelectric point of $\mathrm{pH} 5.5$ while continuous homogenization to increase protein-protein interactions causing aggregation followed by precipitation. After an additional 10 min of homogenizing upon confirming $\mathrm{pH} 5.5$ as the $\mathrm{pH}$ of the solution, the contents were transferred into centrifuge bottles and centrifuged at 10,000 x G for $15 \mathrm{~min}$ at $4^{\circ} \mathrm{C}$. Following centrifugation, two distinct phases were seen in the centrifuge 
bottles. Precipitated protein having formed a pellet at the bottom of the centrifuge tubes were collected into a freezer cups and the processing water was discarded.

Solubilization strategies consisting of increasing the $\mathrm{pH}$ of the solution to $11.0,11.5$, 12.0, or 12.3 using either $\mathrm{NaOH}$ or $\mathrm{Ca}(\mathrm{OH})_{2}$ were randomized using JMP software (version 10.2, SAS Inst., Cary, NC) prior to experimentation. Isoelectric solubilization and precipitation was individually replicated 3 times for each solubilization strategy tested. Recovered lipid and protein fractions were frozen at $-80^{\circ} \mathrm{C}$ first, and then freeze-dried (VirTis Genesis, SP Scientific, Gardiner, NY, USA). Samples were then stored at refrigeration temperatures $\left(4^{\circ} \mathrm{C}\right)$ until further analysis.

\subsection{Proximate analyses}

Proximate composition (ash, fat, and crude protein content) was measured according to guidelines provided in the Association of Official Analytical Chemists (1995) for the recovered protein, and lipid fractions as well as the initial starting material to assess the efficiency of the tested protein solubilization strategies ${ }^{23}$. Data was collected from 3 individual replications for each tested fraction, and presented as mean \pm standard deviation ( $\mathrm{g} / 100 \mathrm{~g}$ of sample, dry basis).

\subsubsection{Moisture and Ash Content}

Sample moisture was determined by the oven-drying method. Each aluminum pan containing 1-2 g of sample were placed in an oven (Fisher Scientific, Fairlawn, NJ) and dried for $24 \mathrm{~h}$ at $105^{\circ} \mathrm{C}^{6}$. Subtracting the dry weight of the sample from the initial weight displayed the final moisture. Ash amount was determined by pacing the dry samples into crucibles to be heated in a muffle furnace oven (Fisher Scientific, Fairlawn, NJ) at $550^{\circ} \mathrm{C}$ for $24 \mathrm{~h}^{6}$. Each sample collected using different solubilization strategies were replicated 3 times and data was presented as mean \pm standard deviation. 


\subsubsection{Fat and Crude Protein Content}

Soxhlet and Kjeldahl analyses were performed on samples for determining fat and crude protein content respectively. Samples weighing (1-2 g) were placed in Whatman No.41 filter paper, folded and attached with a paper clip to avoid unfolding during Soxhlet extraction ${ }^{6}$. Petroleum ether was used to extract lipids and the samples were taken out of the Soxhlet extractor after $18-24 \mathrm{~h}$. After being dried for $24 \mathrm{~h}$ at $105^{\circ} \mathrm{C}$, the sample weight were recorded for lipid content calculations. Crude protein content was measured for samples $(0.5-1 \mathrm{~g}) \mathrm{using}$ Kjeldahl analyzer (Kjeltec 2300, Tecator Technology, Foss, Hillerød, Denmark) ${ }^{6}$. Samples from each solubilization strategy was replicated 3 times and the data was provided as mean \pm standard deviation. Moisture content of the samples were used to calculate lipid and protein amount on dry basis to avoid the effect of moisture content on the interpretation of lipid and protein concentration.

\subsection{Protein and Lipid Recovery Yields}

Protein and lipid recovery yield calculations are based on the amount of protein recovered from the total amount of available protein at the initial source ${ }^{6}$ :

$$
\begin{aligned}
& \text { Protein recovery yield }=\frac{\text { weight of recovered catfish protein }(\mathrm{g})(\text { Kjeldahl, dry basis })}{\text { weight of protein in ground catfish paste }(\mathrm{g})(\text { Kjeldahl, dry basis })} \\
& \text { Lipid recovery yield }=\frac{\text { weight of recovered catfish protein }(\mathrm{g})(\text { Soxhlet, dry basis })}{\text { weight of protein in ground catfish paste }(\mathrm{g})(\text { Soxhlet, dry basis })}
\end{aligned}
$$

2.5. Mineral profile analysis

Application of different solubilization strategies using different processing chemicals have an impact on the mineral content (iron $(\mathrm{Fe})$, magnesium $(\mathrm{Mg})$, calcium $(\mathrm{Ca})$, phosphorus 
$(\mathrm{P})$, and sodium $(\mathrm{Na}))$ of the recovered protein fractions ${ }^{11,12}$. Therefore, mineral profile of samples from each solubilization strategy tested was determined as described elsewhere ${ }^{6}$. The mineral contents from the samples were also compared to the mineral profile of the initial starting material as a control, and to Alaska Pollock surimi as the industry standard for fish mince products. Flasks, funnels and all the other equipment used in the mineral profile analysis were dipped in a $10 \% \mathrm{HCl}$ solution overnight for sanitation and to avoid dust particle interference with the analysis results. Samples were ashed first as described previously, and then dissolved in $2 \mathrm{~mL}$ of $70 \%$ nitric acid for mineral dissociation. Whatman No.1 filter paper was placed inside funnels and the samples were filtered through the filter paper into $50 \mathrm{~mL}$ flasks. The solution was diluted with distilled deionized $(\mathrm{d} / \mathrm{d})$ water up to the $50 \mathrm{~mL}$ mark on the flasks. Samples $(10 \mathrm{~mL})$ were then transferred to separate tubes and analyzed using inductively coupled plasma optical emission spectrometry (model P400; Perkin-Elmer, Shelton, CT) ${ }^{6}$. Each protein fraction recovered using different solubilization strategies, initial ground fish and Alaska Pollock surimi samples were individually replicated 3 times. The results obtained from optical emission spectroscope was adjusted according to sample weight to avoid differences due to sample weight. Mineral profile data was presented as mean \pm standard deviation.

\subsection{Statistical analysis}

Each solubilization strategy was randomized prior to experimentation. All analyses were replicated 3 times individually for each solubilization strategy tested and data was shown as mean \pm standard deviation. Statistical analysis and randomization of trials were conducted using JMP 10.2 software (SAS Inst., Cary, NC, USA). Means values of all applied strategies were separated using Tukey's honestly significant differences test at a significance level of 0.05 , and different letters were assigned to significantly different results $\left({ }^{\mathrm{a}, \mathrm{b}, \mathrm{c}, \mathrm{d}, \mathrm{e}, \mathrm{f}, \mathrm{g}}\right)$. Significant differences 
between application of different acid and base combinations within the fractions solubilized at the same $\mathrm{pH}$ were also evaluated, separated using Tukey's honestly significant differences test at a significance level at 0.05 where significant differences are indicated with different letters $\left({ }^{\mathrm{w}, \mathrm{x}, \mathrm{y}, \mathrm{Z}}\right)$ unless indicated otherwise.

\subsection{Optical imaging}

An Olympus MVX10 microscope (Olympus Corporation, Tokyo, Japan) with a 2x/0.50 Plan Apo objective and 6.3x zoom was used to investigate the structure of the freeze-dried protein samples and the initial ground catfish. Two samples were chosen among solubilization and precipitation treatments applied; solubilization at $\mathrm{pH} 11.5$ using $\mathrm{Ca}(\mathrm{OH})_{2}$ and precipitation at $\mathrm{pH} 5.5$ using $\mathrm{AA}$, and solubilization at $\mathrm{pH} 12.0$ using $\mathrm{NaOH}$ and precipitation at $\mathrm{pH} 5.5$ using LA. These two treatments were selected because they yielded similar compositional makeup (ash, lipid, and protein content) with statistically indifferent ( $\mathrm{p}>0.05)$ protein amounts (87-88 $\mathrm{g} / 100 \mathrm{~g}$ ); and therefore, were comparable. Images presented in Figure 1 and 2 were captured using a DP26 color camera (Olympus Corporation, Tokyo, Japan).

\section{Results and Discussion}

\subsection{Proximate Composition of the Recovered Fractions}

Proximate composition (ash, lipid, and protein content) of the recovered protein and lipid samples were investigated and compared to assess the efficacy of the applied solubilization strategies (Table 1). Consistent with previous studies, using $\mathrm{Ca}(\mathrm{OH})_{2}$ displayed higher $(\mathrm{p}<0.05)$ protein concentration in the recovered protein fraction compared to $\mathrm{NaOH}$ at every solubilization $\mathrm{pH}$ tested during ISP processing ${ }^{11}$. This may be explained by the increased protein solubility displayed by $\mathrm{Ca}(\mathrm{OH})_{2}$ application during isoelectric solubilization and precipitation ${ }^{11}$. Although 
it is evident that sodium is an effective protein solubilization agent, calcium was also shown to interact with negatively charged protein groups and decrease electrostatic repulsion between proteins making them soluble ${ }^{24}$. It was also reported that increased osmotic pressure and decreased surface tension are observed at low salt concentrations leading to phase separation ${ }^{25}$. On the other hand, high salt concentrations in the solution increase surface energy due to competition for the solvent, and the tendency of phase separation decreases ${ }^{25}$.

Overall, when $\mathrm{Ca}(\mathrm{OH})_{2}$ was used as the processing base, protein concentration had a range of 88-91 g/100g, and 88-92 g/100g using AA and LA respectively, whereas using $\mathrm{NaOH}$ showed a range of 66-87 g/100 $\mathrm{g}$ and 64-87 g/100g (AA and LA, respectively). This is consistent with a previously reported study where $\mathrm{NaOH}$ and AA were used to recover silver carp protein by ISP application utilizing alkali solubilization, where protein concentration in the recovered protein fraction was $77-82 \mathrm{~g} / 100 \mathrm{~g}^{6}$. On the other hand, when a combination of $1: 1$ formic and lactic acid was used during ISP processing with $\mathrm{NaOH}$, a wide range $51-82 \mathrm{~g} / 100 \mathrm{~g}$ of protein concentration was observed ${ }^{6}$. Therefore, using lactic acid alone rather than in combination improved protein concentration in the recovered protein fraction. Traditionally used hydrochloric acid $(\mathrm{HCl})$ during protein precipitation yielded similar protein concentration results as organic acids, with a range of $89-92 \mathrm{~g} / 100 \mathrm{~g}$ when protein was solubilized using $\mathrm{Ca}(\mathrm{OH})_{2}$ and 74-84 $\mathrm{g} / 100 \mathrm{~g}$ when $\mathrm{NaOH}$ was selected as the processing base ${ }^{6}$.

Although higher protein amounts in the recovered protein were reported ${ }^{26}$, the results highly depend on a variety of internal (initial starting material) and external (ionic strength, solubilization $\mathrm{pH}$, processing acids, and dilution ratio) factors ${ }^{3}$. In this study the interactions of processing base, acid, and tested solubilization $\mathrm{pH}$ value greatly affected the compositional properties of recovered protein fractions. For the most part, using $\mathrm{Ca}(\mathrm{OH})_{2}$ as the processing 
base resulted in higher protein concentration with lower impurities (inscolubles such as skin, scales and bones, and lipids) in the protein fraction compared to $\mathrm{NaOH}$ processing regardless of the processing acid. It is especially important to remove impurities from the protein since they reduce protein functionality, and storage stability of the final product made from the recovered protein such as gels, sausages, and nuggets. For example, lipids that are not effectively separated from protein cause oxidation and decrease protein stability and degrade color of the restructured protein product. It was previously determined that calcium increases the rate of lipid membrane separation from cytoskeletal proteins ${ }^{27}$. The increased protein separation displayed by $\mathrm{Ca}(\mathrm{OH})_{2}$ may be explained by the high ionic availability of $\mathrm{Ca}(\mathrm{OH})_{2}$. When dissociated in an aqueous solution, $\mathrm{Ca}(\mathrm{OH})_{2}$ gives out $\mathrm{Ca}^{2+}$ and $2\left(\mathrm{OH}^{-}\right)$, whereas $\mathrm{NaOH}$ yields $\mathrm{Na}^{+}$and $\mathrm{OH}^{-}$per molecule. Therefore, adding $\mathrm{Ca}(\mathrm{OH})_{2}$ into the solution will increase negative charge accumulation faster than $\mathrm{NaOH}$ processing, therefore, increasing protein solubility. Researchers studying effects of $\mathrm{NaOH}$ solubilization on rice bran observed that $\mathrm{NaOH}$ was able to solubilize majority of proteins; however, it could not hydrolyze cross-linked polypeptides hence was unable to solubilize them ${ }^{28}$.

The effect of using different acids was less evident on protein concentration when solubilization was achieved using $\mathrm{Ca}(\mathrm{OH})_{2}$. The only difference between acids were observed at solubilization $\mathrm{pH}$ 11.0, where precipitation with LA showed higher $(\mathrm{p}<0.05)$ protein amount compared to AA following $\mathrm{Ca}(\mathrm{OH})_{2}$ solubilization. A previous study testing the effects of different acids on protein gelation and $\mathrm{pH}$ reduction concluded that LA was able to reduce $\mathrm{pH}$ to a lower value compared to AA when same amount of each acid was added to the protein solution 29. Therefore, lower amounts of LA will be required to reduce the $\mathrm{pH}$ to 5.5 compared to AA, showing the higher ionic strength of LA. LA $\left(\mathrm{C}_{3} \mathrm{H}_{6} \mathrm{O}_{3}\right)$ having a pKa of 3.86 dissociates into ${ }^{30,31}$; 


\section{$\mathrm{C}_{3} \mathrm{H}_{6} \mathrm{O}_{3} \longmapsto \mathrm{H}^{+}+\mathrm{C}_{3} \mathrm{H}_{5} \mathrm{O}_{3}{ }^{-}$}

The rate of protonation can be calculated from the following equation;

$\mathrm{pKa}=-\log \mathrm{K}_{\mathrm{a}}$ where $\mathrm{K}_{\mathrm{a}}$ is the dissociation constant ${ }^{30}$.

$\mathrm{K}_{\mathrm{a}}=10^{-3.86}=0.000138$ for LA. A similar calculation for retrieving the dissociation constant of AA which has a pKa of 4.76 shows that $K_{a}$ of $A A=10^{-4.76}=0.000017^{32}$. Therefore, LA has a 10 times higher ionization ability than AA, which explains why LA will be more effective than AA when both are added at low amounts while bringing the $\mathrm{pH}$ from 11.0 down to $\mathrm{pH}$ 5.5. Although this is true for precipitation following $\mathrm{Ca}(\mathrm{OH})_{2}$ solubilization, a different trend was observed in protein concentration when $\mathrm{NaOH}$ was used.

Protein precipitation using AA showed higher protein amounts in the recovered protein fraction post $\mathrm{NaOH}$ solubilization at $\mathrm{pH}$ values 11.0 and 12.3 . It was previously shown that LA was not effective in precipitating protein at low ionic concentrations ${ }^{33}$; therefore, solubilization using $\mathrm{NaOH}$ at $\mathrm{pH} 11.0$ might not have produced a high enough negative charge concentration to trigger protein precipitation by LA addition. On the other hand, when weak acids are added at high concentrations, viscosity of solution stays constant ${ }^{34}$. LA being the stronger of the two organic acids, may reach saturation sooner than AA following $\mathrm{NaOH}$ solubilization. This was perhaps not observed with $\mathrm{Ca}(\mathrm{OH})_{2}$ processing due to the higher amount of negative charges accumulated in the solution compared to $\mathrm{NaOH}$ addition.

Contrary to the higher protein concentration results displayed by $\mathrm{Ca}(\mathrm{OH})_{2}$, using $\mathrm{NaOH}$ was more effective $(\mathrm{p}<0.05)$ in lipid isolation at all solubilization $\mathrm{pH}$ values tested. Lipid concentration in the recovered lipid fraction ranged between $81-91 \mathrm{~g} / 100 \mathrm{~kg}$ when $\mathrm{NaOH}$ was applied, and 72-86 g/100 kg when $\mathrm{Ca}(\mathrm{OH})_{2}$ was used. These results are higher than the 
previously reported values of $60 \mathrm{~g} / 100 \mathrm{~g}$ and $73 \mathrm{~g} / 100 \mathrm{~g}$ lipid amounts in the recovered lipid fraction when silver carp was solubilized at 11.5 and 12.0 using $\mathrm{NaOH}$; however, lipid and protein isolation efficiency depends greatly on the fish species used ${ }^{6}$.

Solubilization using $\mathrm{Ca}(\mathrm{OH})_{2}$ yielded a lipid fraction with higher amounts of protein and lower amounts of lipid compared to $\mathrm{NaOH}$ processing at every solubilization $\mathrm{pH}$ tested. Since using $\mathrm{Ca}(\mathrm{OH})_{2}$ solubilized more protein during $\mathrm{pH}$ shift processing, perhaps part of the protein that was partially solubilized, or some that aggregated contributed to the high amount of protein collected with the lipid fraction following $\mathrm{Ca}(\mathrm{OH})_{2}$ processing. High lipid amount recovered using $\mathrm{NaOH}$ is possibly due to the monovalent solvent being able to form fatty acid salts more efficiently compared to the divalent $\mathrm{Ca}(\mathrm{OH})_{2}$. Further analysis looking into recovered amino acid and fatty acid groups in the recovered protein and lipid fractions may be beneficial.

\subsection{Protein and Lipid Recovery Yields}

Protein and lipid recovery yields shown in Figure 1 give insight into the total weights of recovered fractions and assess the efficiency of the extraction by comparing the recovered fraction weight to the total available protein and lipid in the initial starting material. These results are similar to protein recovery results from black bullhead catfish recovered using $\mathrm{HCl}$ with either $\mathrm{NaOH}$ or $\mathrm{Ca}(\mathrm{OH})_{2}(42-52 \mathrm{~g} / 100 \mathrm{~g}$ and $46-57 \mathrm{~g} / 100 \mathrm{~g}$, respectively), conventional surimi processing yields $(58 \mathrm{~g} / 100 \mathrm{~g})$ and herring protein recovery by alkali solubilization $(57.3 \mathrm{~g} / 100 \mathrm{~g})$; however, other ISP processing strategies yielded more, such as $65 \mathrm{~g} / 100 \mathrm{~g}$ reported from alkali solubilized silver carp ${ }^{6,11,35}$. Due to the high ionic build up in the processing solution, saturation might be reached, and protein recovery may be limited. Therefore, recovery yields may be improved by increasing the currently used 1:6 (fish: $\mathrm{d} / \mathrm{d}$ water) dilution ration by increasing dissociated ion concentration ${ }^{11,36,37}$. 
Overall, protein recovery yield is highly affected by solubilization acid, base, and solubilization $\mathrm{pH}$ as well as their interactions $(\mathrm{p}<0.0001)$. Comparison between mean values obtained from different processing strategies showed that the highest protein recovery yields were seen in fractions solubilized with $\mathrm{NaOH}$ at $\mathrm{pH} 12.0$ and precipitated with $\mathrm{LA}$, or when solubilization was achieved at $\mathrm{pH} 12.3$ with $\mathrm{Ca}(\mathrm{OH})_{2}$ followed by LA precipitation. Different processing acids and bases were more effective at different solubilization $\mathrm{pH}$ values. For example, when AA was chosen as the processing acid, solubilization at lower $\mathrm{pH}$ values (11.0 and 11.5) using $\mathrm{NaOH}$ resulted in higher protein recovery (Figure 2). On the other hand, protein recovery using $\mathrm{Ca}(\mathrm{OH})_{2}$ and LA benefited from higher solubilization $\mathrm{pH}$ values (12.0 and 12.3). It is possible that the weaker of the two tested organic acids precipitates proteins in a lower ion containing environment more efficiently. Along with that, $\mathrm{Ca}(\mathrm{OH})_{2}$ and LA increasing ionic strength compared to $\mathrm{LA}$ or $\mathrm{NaOH}$ addition in a solution, may display higher recovery yields if initial ground fish would be more diluted with water to allow for increased molecular reactions driving protein precipitation.

Lipid recovery on the other hand, ranging from $36-56 \mathrm{~g} / 100 \mathrm{~g}$ when $\mathrm{NaOH}$ is used for protein solubilization and $37-100 \mathrm{~g} / 100 \mathrm{~g}$ when protein is processed with $\mathrm{Ca}(\mathrm{OH})_{2} \cdot \mathrm{Ca}(\mathrm{OH})_{2}$ as a processing base during ISP showed higher $(\mathrm{p}<0.05)$ lipid recovery results compared to $\mathrm{NaOH}$ at every $\mathrm{pH}$ tested except for $\mathrm{pH}$ 12.0. This is in correlation with the previously reported results such as $42-66 \mathrm{~g} / 100 \mathrm{~g}$ when $\mathrm{NaOH}$ is used to solubilize silver carp protein ${ }^{36}$. The highest $(\mathrm{p}<0.05)$ lipid recovery reaching $100 \mathrm{~g} / 100 \mathrm{~g}$ was accomplished using $\mathrm{Ca}(\mathrm{OH})_{2}$ at solubiliation $\mathrm{pH}$ 12.3. As discussed earlier, $\mathrm{Ca}(\mathrm{OH})_{2}$ is effective in separating lipids from muscle proteins and higher ionic concentration at extremely high solubilization $\mathrm{pH}$ values, it's efficacy may be improved. 


\subsection{Mineral Content}

Mineral content (Iron (Fe), Magnesium (Mg), Calcium (Ca), Phosphorus (P), and Sodium (Na)) provide insight into the nutritional properties of the recovered protein fractions and therefore measured and compared among different recovery strategies (Table 2). The initial starting material and Alaska Pollock surimi as the industry standard for reconstructed fish protein products were also analyzed for mineral content and compared with the recovered protein fractions (Table 2, statistical data not shown). As expected, calcium amount increased as solubilization $\mathrm{pH}$ increased with the addition of $\mathrm{Ca}(\mathrm{OH})_{2}$ regardless of processing acid. Interestingly, sodium content did not show an increase as a function of increasing $\mathrm{pH}$ when $\mathrm{NaOH}$ was added to solution. Protein solubilized at lower $\mathrm{pH}$ values (11.0, and 11.5) using $\mathrm{NaOH}$ contained higher $(\mathrm{p}<0.05)$ amount of $\mathrm{Na}$ regardless of processing acid with the exception of solubilization at $\mathrm{pH} 12.3$ and precipitation with LA. Solubilizing protein at $\mathrm{pH} 12.3$ using $\mathrm{Ca}(\mathrm{OH})_{2}$ followed by LA precipitation yielded the protein fraction with the highest $(\mathrm{p}<0.05) \mathrm{Ca}$ amount. Moreover, precipitation with LA yielded a protein fraction with higher calcium content compared to AA for every solubilization $\mathrm{pH}$ tested using $\mathrm{Ca}(\mathrm{OH})_{2}$ except for $\mathrm{pH}$ 11.0. Using LA as the processing acid during ISP also resulted in higher sodium content in the protein fraction compared to AA for every solubilization $\mathrm{pH}$ tested that utilize $\mathrm{NaOH}$ except for $\mathrm{pH} 11.5$.

Overall, mineral content was also highly affected by application of different solubilization and precipitation strategies. $\mathrm{Ca}(\mathrm{OH})_{2}$ solubilization in general yielded higher Fe, and $\mathrm{Ca}$, and lower $\mathrm{Na}$ amounts then Alaska Pollock surimi. It is possible to get the daily recommended amounts of nutrients (Table 3 ) by consuming reasonable amounts $(<50 \mathrm{~g}$, dry basis) of recovered protein; however, bioavailability studies are necessary to determine the absorption rates of the minerals. For example, it was determined that only $50 \mathrm{~g} / 100 \mathrm{~g}$ of dietary 
calcium is absorbed in the bone (Figure 3$)^{14}$. Therefore, consuming $12.5 \mathrm{~g}$ of calcium enhanced protein (solubilized using $\mathrm{Ca}(\mathrm{OH})_{2}$ at $\mathrm{pH} 12.3$ and precipitated with $\mathrm{LA}$ ) powder will be adequate as a protective measure for the bones against calcium deficiencies.

\subsection{Optical imaging}

Two samples of freeze-dried recovered protein containing similar $(\mathrm{p}>0.05)$ amount of protein was observed under the microscope to determine the structural changes inflicted on recovered protein when different recovery strategies are used (Figure 4). As a reference, initial ground fish was also lyophilized and observed under the microscope (Figure 5). Protein solubilized at $\mathrm{pH} 11.5$ using $\mathrm{Ca}(\mathrm{OH})_{2}$ and precipitated with AA was visibly more similar to the initial ground fish, whereas protein solubilized at $\mathrm{pH} 12.0$ using $\mathrm{NaOH}$ and precipitated with LA was more hydrolyzed, and had formed smaller crystals. Although the differences may be attributed to a number of factors (solubilization $\mathrm{pH}$, processing acid or base), gels developed from protein extracted using AA formed covalently linked polymers and were less hydrolyzed compared to LA processed protein gels indicated by sodium dodecyl sulfate polyacrylamide gel electrophoresis (SDS-PAGE) results ${ }^{41}$. Therefore, it will be beneficial to examine recovered protein fractions using SDS-PAGE to get a better understanding of the protein groups and structural changes in protein.

\section{Conclusions}

Overall, organic acids provided as efficient protein precipitation and recovery as traditionally used $\mathrm{HCl} . \mathrm{Ca}(\mathrm{OH})_{2}$ was more effective in protein solubilization than $\mathrm{NaOH}$ indicated by the protein content in the protein fractions. On the other hand, solubilization with $\mathrm{NaOH}$ increased lipid concentration. The effect of processing acid was less evident compared to 
processing base by means of protein concentration, where $\mathrm{Ca}(\mathrm{OH})_{2}$ proved as an alternative processing base. Using $\mathrm{Ca}(\mathrm{OH})_{2}$ resulted in a calcium enhanced protein fraction having lower amounts of sodium.

\section{Acknowledgements}

This work was funded by the HATCH Program Project \# (WVA 00622). 
References

1. Houser, A.; Collins, C. Growth of black bullhead catfish in Oklahoma. Norman, Okla.: Oklahoma Fishery Research Laboratory, 1962.

2. Cooperative Extension Program, University of Arkansas at Pine Bluff, U.S. Department of Agriculture, and County Governments in cooperation with the Arkansas Game and Fish Commission. Farm Pond Management for Recreational Fishing. Form number MP360-500-511R. Retrieved from http://www.uaex.edu/publications/pdf/MP360.pdf, accessed on March 2, 2015.

3. Gehring, C.K.; Gigliotti, J. C.; Moritz, J. S.; Tou, J. C.; Jaczynski, J. Functional and nutritional characteristics of proteins and lipids recovered by isoelectric processing of fish by-products and low-value fish: A review. Food Chem. 2011, 124, 422-431.

4. Liang, Y.; Hultin, H. Functional protein isolates from mechanically deboned turkey by alkaline solubilization with isoelectric precipitation. J. Muscle Foods 2003, 14, 195- 205.

5. Hultin H. O.; Kelleher, S.D. Advance Protein Technologies Inc., assignee. Process for isolating a protein composition from a muscle source and protein composition, 1999. Patent $6,005,073$.

6. Paker, I.; Beamer, S.; Jaczynski, J.; Matak, K. E. Compositional characteristics of materials recovered from headed gutted silver carp (Hypophthalmichthys molitrix) by isoelectric solubilization and precipitation using organic acids. J. Food Sci. 2013, 78, E445-E451.

7. Raghavan, S.; Kristinsson, H. G. Conformational and rheological changes in catfish myosin during alkali-induced unfolding and refolding. Food Chem. 2008, 107, 385-398.

8. Paker, I.; Beamer, S.; Jaczynski, J.; Matak, K. E. The effect of organic acids on gelation characteristics of protein gels made from silver carp (Hypophthalmichthys molitrix) protein recovered by isoelectric solubilization and precipitation. LWT - Food Sci. Technol. 2013, 53, 3743. 
9. Paker, I.; Beamer, S.; Jaczynski, J.; Matak, K. E. pH shift protein recovery with organic acids on texture and color of cooked gels. J Sci. Food Agr. 2015, 95, 275-280.

10. Paker, I. Compositional characteristics of materials recovered from headed gutted silver carp (Hypophthalmichthys molitrix) by isoelectric solubilization and precipitation using organic acids. In Compositional Compositional and functional characteristics of materials recovered from headed gutted silver carp (Hypophthalmichthys molitrix) by isoelectric solubilization and precipitation using organic acids. Master's thesis prepared for Davis College of Agriculture, Natural Resources and Design, West Virginia University, Morgantown, WV. 2012.

11. Paker, I. Calcium hydroxide as a potential base in alkali aided $\mathrm{pH}$ shift process. In Calcium enhanced protein recovery from underutilized aquatic resources and optimizing protein gelation strategies using functional ingredients, PhD Dissertation prepared for Davis College of Agriculture, Natural Resources and Design, West Virginia University, Morgantown, WV. 2015.

12. Bertram, M. Y.; Steyn, K.; Wentzel-Viljoen, E.; Tollman, S.; Hofman, K. J. Reducing the sodium content of high-salt foods: Effect on cardiovascular disease in South Africa. S. Afr. Med. J. 2012, 102, 743-745.

13. Bartl, R.; Frisch, B. Bertha Frisch. Calcium and vitamin D. In Osteoporosis Diagnosis, Prevention, Therapy Second Revised Edition; Bartl, R.; Frisch, B., Eds.: Springer-Verlag Berlin Heidelberg, Germany, 2009; pp.111-117.

14. Otto, R.A.; Beamer, S.; Jaczynski, J.; Matak, K.E. The effect of using citric or acetic acid on survival of Listeria monocytogenes during fish protein recovery by isoelectric solubilization and precipitation process. J. Food Sci. 2011, 76, M579-583.

15. Otto, R.A.; Paker, I.; Bane, L.; Beamer, S.; Jaczynski, J.; Matak, K. E. 2011b. Survival of Listeria inocсиa in rainbow trout protein recovered by isoelectric solubilization and precipitation with acetic and citric acids. J. Food Prot. 2011, 74, 1348-1352.

16. Lansdowne, L.R.; Beamer, S.; Jaczynski, J.; Matak, K. E. Survival of Escherichia coli after isoelectric solubilization and precipitation of fish protein. J. Food Prot. 2009, 7, 1398-1403. 
17. Lansdowne, L.R.; Beamer, S.; Jaczynski, J.; Matak, K. E. Survival of Listeria innocua after isoelectric solubilization and precipitation of fish protein. J. Food Sci. 2009, 74, M201-M205.

18. 19. De Wit, J. S.; Rombout, F. M. Antimicrobial activity of sodium lactate. Food Micro. 1990, 7, 113-120.

19. Knock, R. C.; Seyfert, M.; Hunt, M. C.; Dikeman, M. E.; Mancini, R. A.; Unruh, J.A. et al. Effects of potassium lactate, sodium chloride, sodium tripolyphosphate, and sodium acetate on colour, colour stability, and oxidative properties of injection-enhanced beef rib steaks. Meat Sci. 2006, 74, 312-318.

20. Jensen, J. M.; Robbins, K. L.; Ryan, K. J.; Homco-Ryan, C.; McKeith, F. K.; Brewer, M. S. Effects of lactic and acetic acid salts on quality characteristics of enhanced pork during retail display. Meat Sci. 2003, 63, 501-508.

21. United States Food and Drug Administration. Safe and suitable ingredients used in the production of meat, poultry, and egg products. 7120.1, Rev. 23. United States Department of Agriculture Food Safety and Inspection Service: Washington, D. C., 2014.

22. Gault, N. F. S. The influence of acetic acid concentration on the efficiency of marinading as a process for tenderizing beef. In Proceedings of the $30^{\text {th }}$ European Meeting of Meat Research Workers: Bristol, UK, 1984; pp.184-185.

23. Association of Official Analytical Chemists. In Official Methods of Analysis, 16th ed.; Association of Official Analytical Chemists: Washington, D.C., 1995.

24. Faccia, M.; Angiolillo, L.; Mastromatteo, M.; Conte, A.; Del nob ile matteo, A. The effect of incorporating calcium lactate in the saline solution on improving the shelf life of Fiordilatte cheese. Int. J. Dairy Technol. 2013, 66, 373-381.

25. Rozhkov, S. P. Solubility and phase transitions in the water-protein-salt system. Biofizika 2006, 51, 822-826.

26. Taskaya, L.; Chen, Y.C.; Beamer, S.; Tou, J.C.; Jaczynski, J. Compositional characteristics of materials recovered from whole gutted silver carp (Hypophthalmichthys molitrix) using isoelectrical solubilization/precipitation. J. Agric. Food Chem. 2009, 57, 4259-4266. 
27. Liang, Y.; Hultin, H. O. Separation of membranes from acid-solubilized fish muscle proteins with the aid of calcium ions and organic acids. J. Agric. Food Chem. 2005, 53, 3008-3016.

28. Hamada, J. S. Characterization of protein fractions of rice bran to devise effective methods of protein solubilization. Cereal Chem. 1997, 74, 662-668.

29. Chawla, S. P.; Venugopal, V.; Nair, P. M. Gelation of proteins from washed muscle of Threadfin Bream (Nemipterus japonicus) under mild acidic conditions. J. Food Sci. 1996, 61, $362-367$.

30. Zevatskii, Y. E.; Samoilova, D. V.; Mchedlov-Petrosyan, N. O. Contemporary methods for the experimental determination of dissociation constants of organic acids in solutions. Russ. J. Gen. Chem. 2009, 79, 1859-1889.

31. Partanen, J. I.; Juusola, P. M.; Minkkinen, P. O. Determination of stoichiometric dissociation constants of lactic acid in aqueous salt solutions at 291.15 and at 298.15 K. Fluid Phase Equilibr. 2003, 204, 245-266.

32. Partanen, J. L.; Covington, A. K. Determination of Stoichiometric dissociation constants of acetic acid in aqueous solutions containing acetic acid, sodium acetate, and sodium chloride at ( 0 to 60$)^{\circ}$ C. J. Chem. Eng. Data 2003, 48, 797-807.

33. Lu, J. Use of calcium salts for soybean curd preparation. J. Food Sci. 1980, 45, 32-34.

34. Rinaudo, M.; Pavlov, G.; Desbrie`res, J. Influence of acetic acid concentration on the solubilization of chitosan. Polymers, 1999, 40, 7029-7032.

35. Marmon, S. K.; Undeland, I. Protein isolation from gutted herring (Clupea harengus) using pH-shift processes. J. Agric. Food Chem. 2010, 58, 10480-10486.

36. Kim, Y. S.; Park, J. W.; Choi, Y. J. New approaches for the effective recovery of fish proteins and their physicochemical characteristics. Fisheries Sci. 2003, 69, 1231-1239.

37. Dagher, S.M.; Hultin, H.O.; Liang, Y. Solubility of cod muscle myofibrillar proteins at alkaline pH. J. Aqua Food Product Technical. 2000, 9, 49-59.

38. Taskaya, L.; Chen, Y.C.; Beamer, S.; Jaczynski ,J. Texture and colour properties of proteins recovered from whole gutted silver carp (Hypophthalmichthys molitrix) using isoelectric solubilisation/precipitation. J. Sci. Food Agric. 2009, 89, 349-358. 
39. United States Department of Agriculture, Dietary Reference Intakes (DRIs): Estimated Average Requirements Food and Nutrition Board, Institute of Medicine, National Academies. Retrieved from http://www.nal.usda.gov/fnic/DRI/DRI_Tables/recommended_intakes_individuals.pdf 40. National Institutes of Health, Sodium in diet. Retrieved from http://www.nlm.nih.gov/medlineplus/ency/article/002415.htm 41. Gimenez, B.; Turnay, J.; Lizarbe, M. A.; Montero, P.; Gomez-Guillen, M. C. Use of lactic acid for extraction of fish skin gelatin. Food Hydrocolloid. 2005, 19: 941-950. 
Table 1. Proximate composition of the recovered protein and lipid fractions using different solubilization strategies and initial starting material (ground catfish).

\section{Recovered Protein Fraction}

\begin{tabular}{|c|c|c|c|c|c|}
\hline Solubilization $\mathrm{pH}$ & Base & Acid & Ash (g/100g) & Lipid (g/100g) & Protein $(\mathrm{g} / 100 \mathrm{~g})$ \\
\hline \multirow{4}{*}{11.0} & $\mathrm{Ca}(\mathrm{OH})_{2}$ & $\mathrm{LA}$ & $2.03 \pm 0.46 \mathrm{~d}, \mathrm{z}$ & $5.45 \pm 0.11 \mathrm{gh}, \mathrm{z}$ & $92.29 \pm 0.52 \mathrm{a}, \mathrm{w}$ \\
\hline & $\mathrm{Ca}(\mathrm{OH})_{2}$ & AA & $4.08 \pm 0.04 \mathrm{~cd}, \mathrm{z}$ & $5.60 \pm 1.28 \mathrm{gh}, \mathrm{z}$ & $90.12 \pm 1.21 \mathrm{abc}, \mathrm{x}$ \\
\hline & $\mathrm{NaOH}$ & LA & $15.93 \pm 1.74 a, x$ & $9.21 \pm 1.34$ cde,y & $74.53 \pm 0.67 \mathrm{e}, \mathrm{z}$ \\
\hline & $\mathrm{NaOH}$ & $\mathrm{AA}$ & $8.79 \pm 0.35 b, y$ & $10.27 \pm 0.60 \mathrm{c}, \mathrm{y}$ & $80.61 \pm 0.33 \mathrm{~d}, y$ \\
\hline \multirow{4}{*}{11.5} & $\mathrm{Ca}(\mathrm{OH})_{2}$ & $\mathrm{LA}$ & $2.73 \pm 0.19 \mathrm{~cd}, \mathrm{z}$ & $6.73 \pm 0.79$ efg,z & $89.97 \pm 1.09 a b c, y$ \\
\hline & $\mathrm{NaOH}$ & AA & $10.57 \pm 0.98 b, y$ & $23.08 \pm 1.14 a, x$ & $65.96 \pm 1.12 \mathrm{f}, \mathrm{z}$ \\
\hline & $\mathrm{NaOH}$ & LA & $17.04 \pm 0.53 a, x$ & $18.75 \pm 1.94$ b,y & $63.95 \pm 2.64 \mathrm{f}, \mathrm{z}$ \\
\hline & $\mathrm{Ca}(\mathrm{OH})_{2}$ & AA & $2.83 \pm 0.12 \mathrm{~cd}, \mathrm{z}$ & $8.71 \pm 0.16$ cdef,z & $88.30 \pm 0.31 b c, y$ \\
\hline \multirow{4}{*}{12.0} & $\mathrm{Ca}(\mathrm{OH})_{2}$ & $\mathrm{LA}$ & $4.00 \pm 0.30 \mathrm{~cd}, x$ & $3.81 \pm 1.81 h, z$ & $91.84 \pm 0.52 \mathrm{a}, \mathrm{y}$ \\
\hline & $\mathrm{NaOH}$ & $\mathrm{AA}$ & $2.53 \pm 0.07 d, z$ & $9.73 \pm 1.07 \mathrm{~cd}, \mathrm{x}$ & $87.40 \pm 1.07 \mathrm{c}, \mathrm{z}$ \\
\hline & $\mathrm{NaOH}$ & LA & $3.41 \pm 0.23 \mathrm{~cd}, y$ & $8.98 \pm 0.64 \mathrm{cde}, x$ & $87.33 \pm 0.68 c, z$ \\
\hline & $\mathrm{Ca}(\mathrm{OH})_{2}$ & AA & $2.45 \pm 0.11 d, z$ & $6.56 \pm 0.85$ efgh,y & $90.91 \pm 0.87 a b, y$ \\
\hline \multirow{4}{*}{12.3} & $\mathrm{Ca}(\mathrm{OH})_{2}$ & LA & $4.70 \pm 0.42 c, z$ & $7.02 \pm 0.70$ defg,y & $87.89 \pm 0.91 b c, x$ \\
\hline & $\mathrm{NaOH}$ & $\mathrm{AA}$ & $9.39 \pm 0.32 b, y$ & $9.18 \pm 0.29$ cde, $x$ & $81.31 \pm 0.07 \mathrm{~d}, \mathrm{y}$ \\
\hline & $\mathrm{NaOH}$ & LA & $14.95 \pm 1.72 a, x$ & $5.99 \pm 0.76 \mathrm{fgh}, \mathrm{y}$ & $78.61 \pm 1.30 \mathrm{~d}, \mathrm{z}$ \\
\hline & $\mathrm{Ca}(\mathrm{OH})_{2}$ & $\mathrm{AA}$ & $4.06 \pm 0.21 \mathrm{~cd}, \mathrm{z}$ & $7.41 \pm 0.88$ cdefg,xy & $88.28 \pm 0.73 b c, x$ \\
\hline \multicolumn{2}{|c|}{ Initial, Ground Catfish } & & $8.00 \pm 0.74$ & $38.18 \pm 3.22$ & $53.71 \pm 3.32$ \\
\hline
\end{tabular}

Recovered Lipid Fraction

\begin{tabular}{|c|c|c|c|c|}
\hline Solubilization $\mathrm{pH}$ & Base & Ash (g/100g) & Lipid (g/100g) & Protein $(\mathrm{g} / 100 \mathrm{~g})$ \\
\hline 11.0 & $\mathrm{NaOH}$ & $2.16 \pm 0.57 c$ & $90.13 \pm 0.51 \mathrm{a}$ & $7.42 \pm 0.84 \mathrm{e}$ \\
\hline 11.0 & $\mathrm{Ca}(\mathrm{OH})_{2}$ & $4.96 \pm 0.40 \mathrm{~b}$ & $75.43 \pm 0.59 \mathrm{de}$ & $18.94 \pm 1.24 b$ \\
\hline 11.5 & $\mathrm{NaOH}$ & $9.76 \pm 0.45 a$ & $81.21 \pm 2.45 \mathrm{c}$ & $8.49 \pm 2.13 \mathrm{de}$ \\
\hline 11.5 & $\mathrm{Ca}(\mathrm{OH})_{2}$ & $5.09 \pm 0.42 b$ & $72.49 \pm 0.94 \mathrm{e}$ & $22.01 \pm 1.14$ a \\
\hline 12.0 & $\mathrm{NaOH}$ & $1.65 \pm 0.20 c$ & $91.06 \pm 0.59 \mathrm{a}$ & $6.89 \pm 0.34 \mathrm{e}$ \\
\hline 12.0 & $\mathrm{Ca}(\mathrm{OH})_{2}$ & $10.67 \pm 1.11 \mathrm{a}$ & $76.81 \pm 1.04 \mathrm{~d}$ & $12.01 \pm 0.33 \mathrm{c}$ \\
\hline 12.3 & $\mathrm{NaOH}$ & $1.90 \pm 0.04 \mathrm{c}$ & $89.55 \pm 0.20 \mathrm{a}$ & $7.88 \pm 0.16 \mathrm{de}$ \\
\hline 12.3 & $\mathrm{Ca}(\mathrm{OH})_{2}$ & $2.78 \pm 0.52 c$ & $86.04 \pm 0.07 b$ & $10.55 \pm 0.32 \mathrm{~cd}$ \\
\hline
\end{tabular}

$\overline{\mathrm{a}, \mathrm{b}, \mathrm{c}, \mathrm{d}, \mathrm{e}, \mathrm{f}}$ Mean values in a column with different letters are significantly different (Tukey's honestly significant difference test, $\mathrm{p}<0.05)$.

${ }^{\mathrm{w}, \mathrm{x}, \mathrm{y}, \mathrm{z}}$ Mean values of protein fraction data in a column solubilized using the same solubilization $\mathrm{pH}$ with different letters are significantly different (Tukey's honestly significant difference test, $\mathrm{p}<0.05)$.

Bold values indicate significant differences between $\mathrm{NaOH}$ and $\mathrm{Ca}(\mathrm{OH})_{2}$ within the same solubilization $\mathrm{pH}$ (one way ANOVA test, $\mathrm{p}<0.05$ ) applied for lipid recovery results. 
Table 2. Mineral composition (Iron (Fe), Magnesium (Mg), Calcium (Ca), Phosphorus (P), and Sodium (Na)) of the recovered protein using different $\mathrm{pH}$ shift treatments.

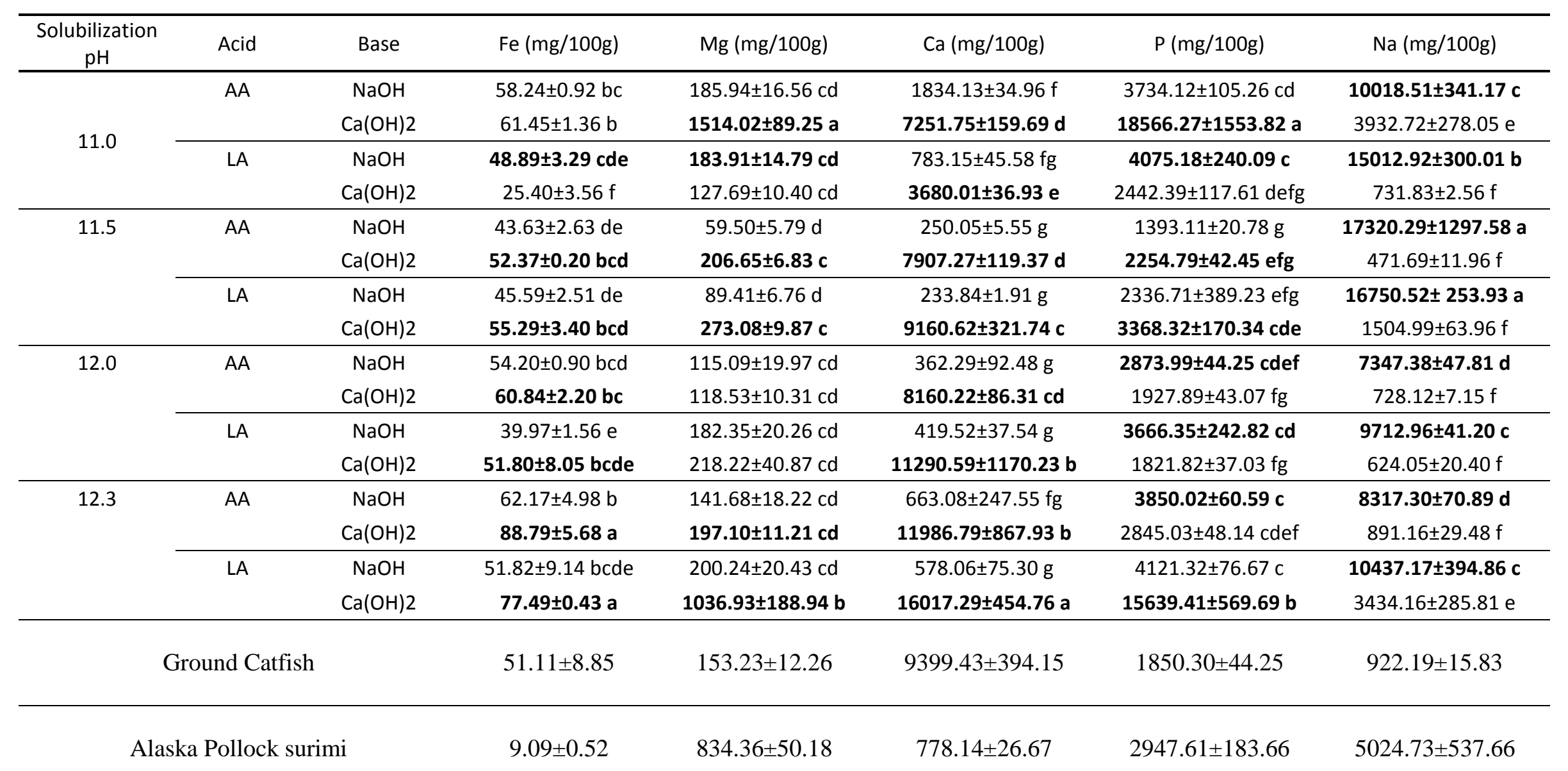

$\overline{\mathrm{a}, \mathrm{b}, \mathrm{c}, \mathrm{d}, \mathrm{e}, \mathrm{f}, \mathrm{g}}$ Mean values in a column with different letters are significantly different (Tukey's honestly significant difference test, $\mathrm{p}<0.05)$.

Bold values indicate significant differences between $\mathrm{NaOH}$ and $\mathrm{Ca}(\mathrm{OH})_{2}$ within the same solubilization $\mathrm{pH}$ and processing acid (one way ANOVA test, $\mathrm{p}<0.05)$. 
Table 3. Daily recommended levels of Protein, Iron (Fe), Magnesium (Mg), Calcium (Ca), and Phosphorus (P), and daily upper limit of Sodium (Na).

\begin{tabular}{|c|c|c|c|c|c|c|}
\hline \multicolumn{6}{|c|}{ Recommended Average Intake } & \multirow{2}{*}{$\frac{\text { Limit }}{\text { Na (mg/d) }}$} \\
\hline Life Stage & $\begin{array}{l}\text { Protein } \\
\text { (g/kg/d) }\end{array}$ & Fe (mg/d) & $\operatorname{Mg}(\mathrm{mg} / \mathrm{d})$ & $\mathrm{Ca}(\mathrm{mg} / \mathrm{d})$ & $\mathbf{P}(\mathrm{mg} / \mathrm{d})$ & \\
\hline $\begin{array}{l}\text { Child } \\
(1-3 y)\end{array}$ & 0.87 & 3.0 & 65 & 500 & 380 & - \\
\hline $\begin{array}{l}\text { Child } \\
(4-8 \text { y) }\end{array}$ & 0.76 & 4.1 & 110 & 800 & 405 & - \\
\hline $\begin{array}{l}\text { Adult } \\
(9-18 \text { y) }\end{array}$ & $0.73-0.76$ & $5.9-7.7$ & $200-340$ & 1,100 & 1,055 & 2,300 \\
\hline $\begin{array}{l}\text { Adult } \\
(19-50 \text { y) }\end{array}$ & 0.66 & 8.1 & $330-350$ & 800 & 580 & 2,300 \\
\hline $\begin{array}{l}\text { Adult } \\
(>50 \text { y) }\end{array}$ & 0.66 & 5 & 350 & 1000 & 580 & 1,500 \\
\hline
\end{tabular}




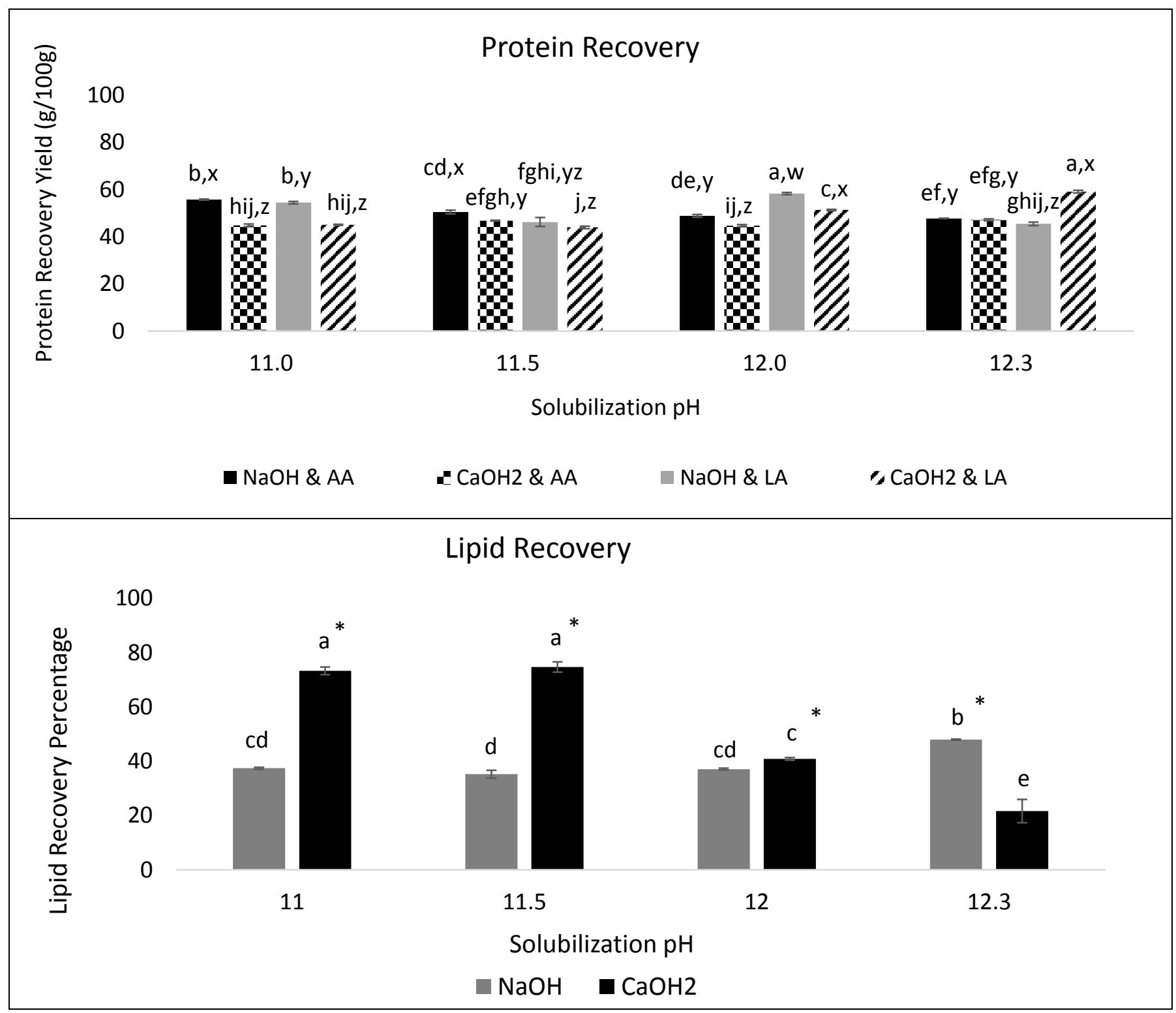

Figure 1. Protein and lipid recovery yields of different solubilization strategies.

a,b,c,d,e,f,g,h,i,j Mean values with different letters are significantly different (Tukey’s honestly significant difference test, $\mathrm{p}<0.05)$.

${ }_{\mathrm{w}, \mathrm{x}, \mathrm{y}, \mathrm{z}}$ Mean values of protein recovery yield within the same solubilization $\mathrm{pH}$ with different letters are significantly different (Tukey's honestly significant difference test, $\mathrm{p}<0.05$ ).

Significant differences between $\mathrm{NaOH}$ and $\mathrm{Ca}(\mathrm{OH})_{2}$ with in the same solubilization $\mathrm{pH}$ (one way ANOVA test, $\mathrm{p}<0.05)$ are indicated with an * for lipid recovery. 


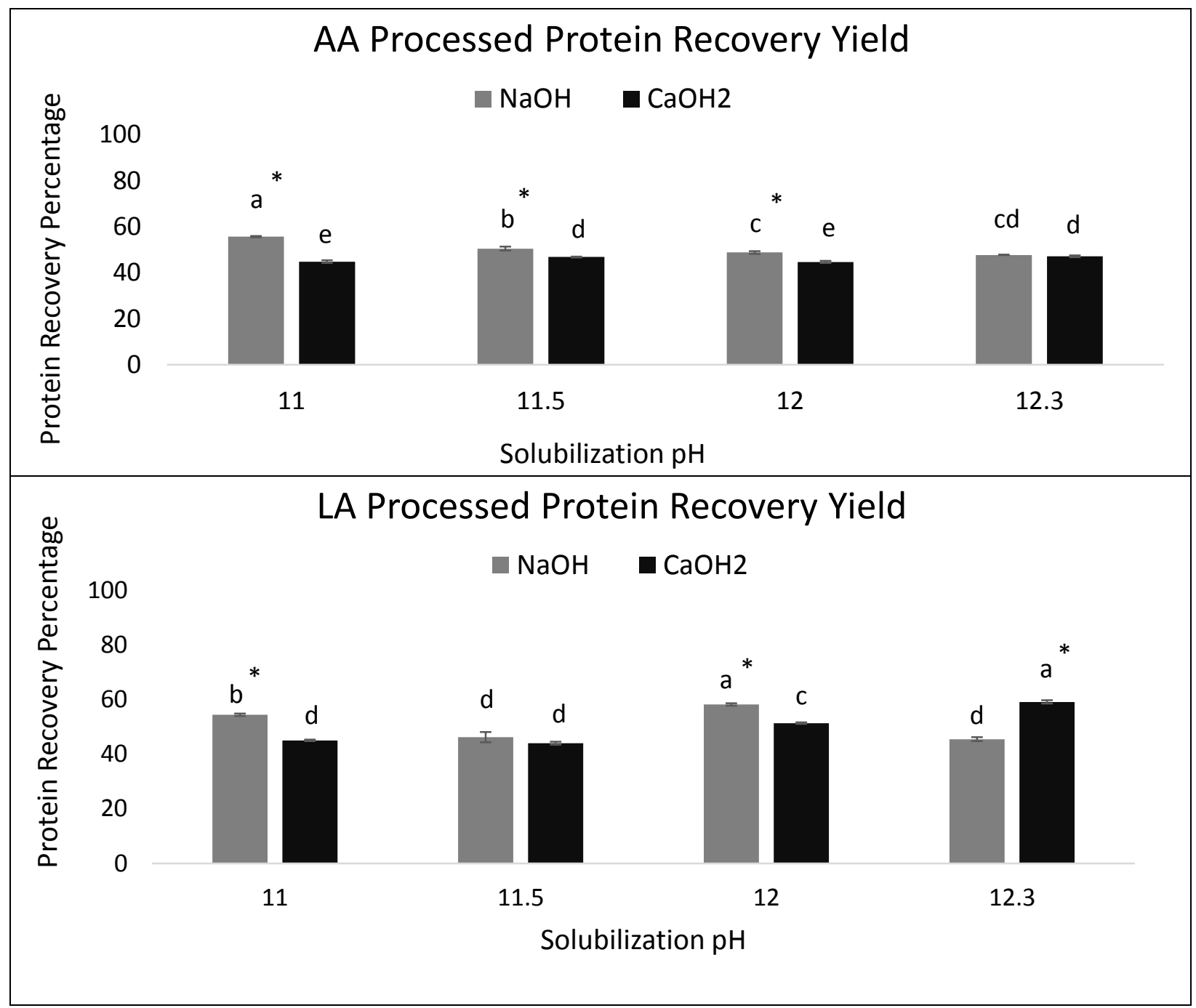

Figure 2. Protein recovery yields obtained by using different precipitation strategies.

a,b,c,d Mean values with different letters are significantly different (Tukey's honestly significant difference test, $\mathrm{p}<0.05)$. Significant differences between $\mathrm{NaOH}$ and $\mathrm{Ca}(\mathrm{OH})_{2}$ with in the same solubilization $\mathrm{pH}$ (one way ANOVA test, $\mathrm{p}<0.05$ ) are indicated with an *. 


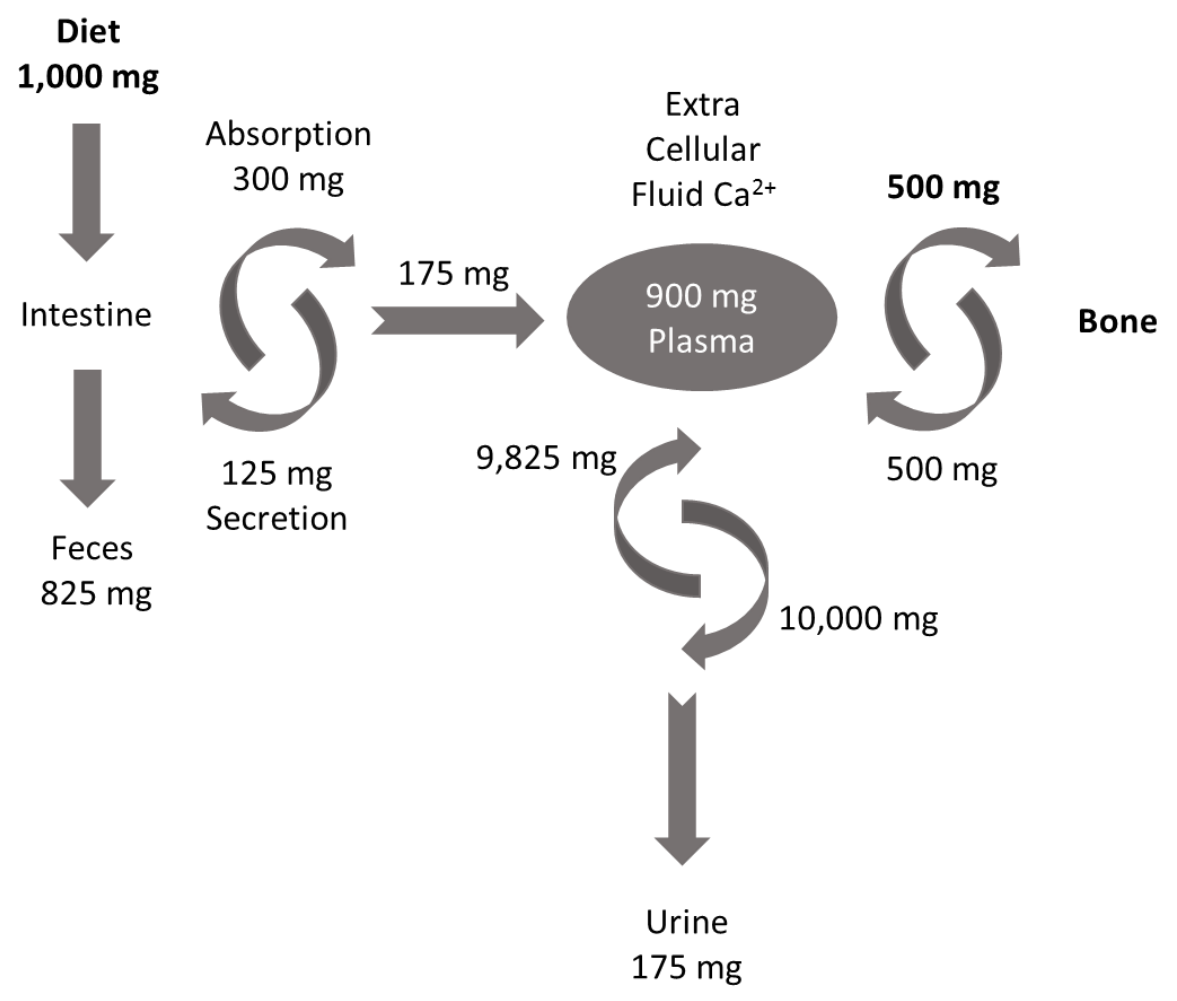

Figure 3. Dietary calcium turnover rate in healthy adults (diagram adapted from Bartl, and Frisch, $2009^{14}$ ) 

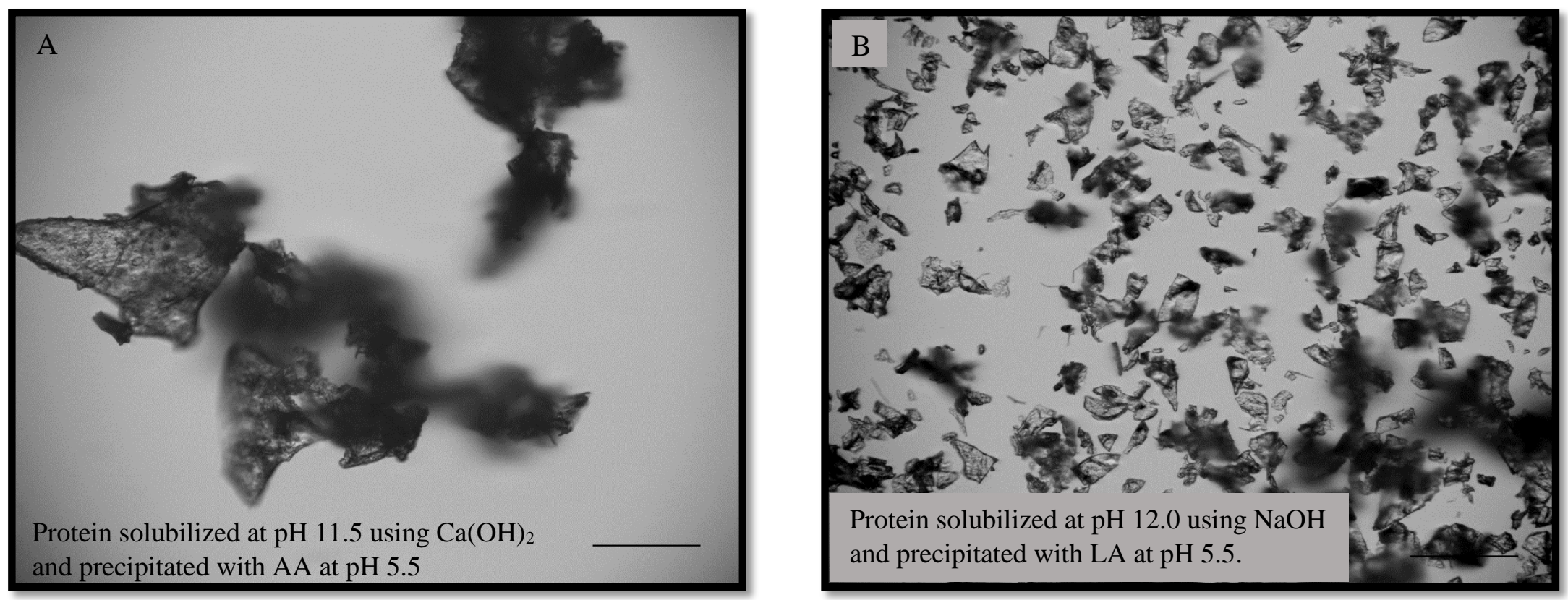

Figure 4. Optical images (6.3x zoom) of the freeze-dried recovered proteins using A. calcium hydroxide $\left(\mathrm{Ca}(\mathrm{OH})_{2}\right)$ to achieve protein solubilization at $\mathrm{pH} 11.5$ and acetic acid (AA) to precipitate protein at $\mathrm{pH}$ 5.5., and $\mathrm{B}$. sodium hydroxide $(\mathrm{NaOH})$ for solubilizing protein at $\mathrm{pH} 12.0$ and achieving precipitation at $\mathrm{pH} 5.5$ with lactic acid (LA). 


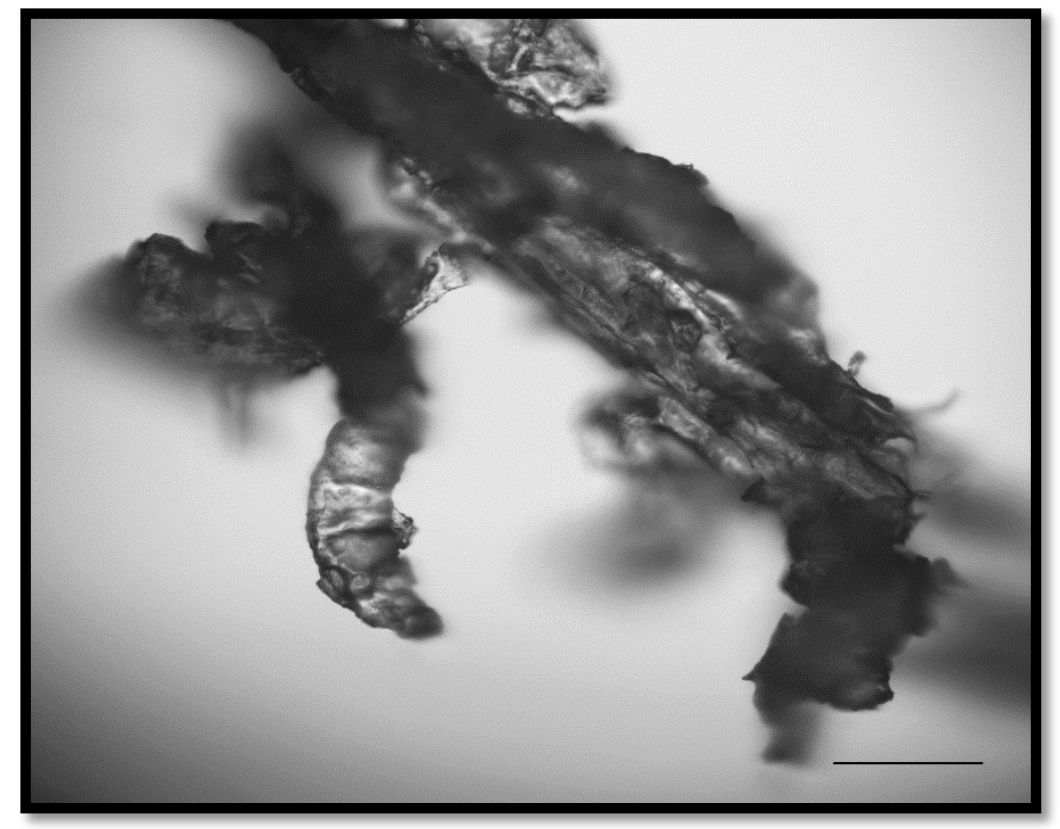

Figure 5. Optical image (6.3x zoom) of the freeze-dried, gutted, and ground black bullhead catfish. 


\title{
CHAPTER 3
}

\section{Influence of Pre-Cooking Protein Paste Gelation Conditions and Post-Cooking Gel Storage Conditions on Gel Texture}

\begin{abstract}
BACKGROUND: Gelation conditions affect setting of myofibrillar fish protein gels. Therefore, the impact of widely applied pre-cooking gelation time/temperature strategies and post-cooking period on texture and color of final protein gels was determined. Four pre-cooking gelation strategies (no-setting time, $30 \mathrm{~min}$ at $25^{\circ} \mathrm{C}, 1 \mathrm{~h}$ at $40^{\circ} \mathrm{C}$, or $24 \mathrm{~h}$ at $4^{\circ} \mathrm{C}$ ) were applied to protein pastes (fish protein concentrate and standard functional additives). After cooking, texture and color were either analyzed directly or after $24 \mathrm{~h}$ at $4^{\circ} \mathrm{C}$ on gels adjusted to $25^{\circ} \mathrm{C}$.
\end{abstract}

RESULTS: No-set gels were harder, gummier, and chewier $(\mathrm{p}<0.05)$ when analyzed immediately after cooling; however, gel chewiness, cohesiveness and firmness indicated by Kramer force benefited from $24 \mathrm{~h}$ at $4^{\circ} \mathrm{C}$ gel setting when stored post-cooking. Gel setting conditions had a greater $(\mathrm{p}<0.05)$ effect on texture when directly analyzed and most changes occurred in no-set gels. There were significant $(\mathrm{p}<0.05)$ changes between directly analyzed and post-cooking storage gels in texture and color, depending on pre-cooking gelation strategy.

CONCLUSION: Pre-cooking gelation conditions will affect final protein gel texture and color, with gel stability benefitting from a gel-setting period. However, post-cooking storage may have a greater impact on final gels with textural attributes becoming more consistent between all samples.

Key words: protein gels, texture properties, pH shift, gel setting, color 


\section{Introduction}

Protein gelation conditions will affect the texture of processed fish products and will ultimately impact the acceptability of the final product. Myofibrillar proteins, mainly actin and myosin, are the major contributors to gelation because they form strong gels when heated above $40^{\circ} \mathrm{C}$. Heat-induced gel formation occurs when myofibrillar proteins form a 3-dimensional network matrix due to partial unfolding and irreversible aggregation of myosin heads to adjacent tails through disulfide bonds and hydrophobic interactions ${ }^{1}$. As the protein denaturation and aggregation mechanism proceeds, existing disulphide bonds are broken down and sulphydryl (SH) groups that were inside the unfolded protein are revealed ${ }^{2}$. These $\mathrm{SH}$ groups will enable to form intermolecular bridging and enforce protein gel formation ${ }^{3}$. Consequently, the functional properties that cause intermolecular bridge formation and aggregate formation will ultimately impact textural and sensory properties of the final product. Changing any of the conditions during the development of a protein gel such as compositional concentration, additive amounts and especially heating time and temperature, will alter the structural properties of gels.

The gelation temperature of fish protein depends on the fish species ${ }^{4}$. In general, gelling occurs at low temperatures $\left(0-4^{\circ} \mathrm{C}\right)$ for cold water fish, whereas gels made from warm water fish species need higher temperature conditions $\left(40^{\circ} \mathrm{C}\right)$ for gel formation ${ }^{5}$. Gel setting temperature and time are not the same for each fish species because of different optimal conditions for endogenous transglutaminase (TGase) activity, an enzyme that catalyzes myosin cross-linking, and myofibrillar protein denaturation ${ }^{6}$. The duration and temperature at which gels are set are important as they will impact textural properties of the final product. In addition, the functional and textural properties of gels are influenced by rate of heating (temperature), $\mathrm{pH}$ (net charge), protein concentration and the amount of other food ingredients such as lipids, salts and sugars ${ }^{1,7}$. 
Therefore, the purpose of this study is to investigate the impact of widely used pre- and postcooking gelation strategies on the texture and color of protein gels.

2. Materials and Methods

2.1. Preparation of starting material for protein pastes

Fresh black bullhead catfish (Ameiurus melas) were gutted and rinsed in tap water. The fish were then transferred to stainless steel trays and stored at $-20^{\circ} \mathrm{C}$ for 18 hours to prevent heatinduced denaturation. Fish were ground twice using a coarse grinding filter plate on a meat processor (Hobart Model 4146, Troy, OH, USA). The coarse filter was replaced with a fine plate and ground fish were processed once more, so that the fish paste was free of big bones or chunks of skin. The ground fish was placed into freezer bags, each containing $500 \mathrm{~g}$ fish paste (Ziplock Freezer Bags, S.C. Johnson \& Son, Inc., Racine, WI, USA), and stored at $-80^{\circ} \mathrm{C}$ until the protein separation process was conducted.

\subsection{Protein separation}

The protein used to make gels was separated from the ground fish using a pH-shift method called isoelectric solubilization and precipitation (ISP) process ${ }^{8}$. Briefly, when exposed to high or low $\mathrm{pH}$ extremes, myofibrillar protein solubilizes in solution and is separated from bones, skin, scales, etc., by centrifugation. When the protein solution is returned to the isoelectric point, the protein precipitates out of solution and is separated from the process water by centrifugation. Prior to ISP processing, ground fish was thawed at $4^{\circ} \mathrm{C}$ for $24-48 \mathrm{~h}$. To begin, $1500 \mathrm{~g}$ of ground fish was diluted 1:6 with distilled, deionized $(\mathrm{d} / \mathrm{d})$ water in a glass beaker and homogenized for 5 min (PowerGen 700, Fisher Scientific, Pittsburgh, PA). The pH of the solution was increased to 11.5 using $1 \mathrm{~mol} \mathrm{~L}^{-1}$ calcium hydroxide $\left(\mathrm{Ca}(\mathrm{OH})_{2}\right)$ confirmed using a calibrated pH/ion analyzer (Oakton, Eutech Instruments; Singapore). After reaching the target 
solubilization $\mathrm{pH}$, homogenization continued for an additional $10 \mathrm{~min}$. The slurry was poured into centrifuge bottles and centrifuged at $98066.5 \mathrm{~m} \mathrm{~s}^{-2}$ for $15 \mathrm{~min}$ at $4^{\circ} \mathrm{C}$ (Sorvall RC-SB Refrigerated Superspeed Centrifuge, Du Pont, Wilmington, DE, USA) to allow for phase separation. The top layer consisted of lipids and the bottom pellet consisted of insoluble constituents, such as skin and bones, which were discarded. The middle layer, containing solubilized protein and process water, was filtered through a cheese cloth and poured into a glass beaker. The $\mathrm{pH}$ of the solution was lowered to the protein isoelectric point $(\mathrm{pH}=5.5)$ with the addition of hydrochloric acid $(\mathrm{HCl})$ and the solution was homogenized for an additional 5 min to facilitate protein precipitation. Protein separation was achieved by centrifugation at $98066.5 \mathrm{~m}$ $\mathrm{s}^{-2}$ for $15 \mathrm{~min}$ at $4^{\circ} \mathrm{C}$. After centrifugation was completed, the supernatant was discarded and the protein which had formed a pellet at the bottom of the centrifuge tube was collected using a steel spatula.

\subsection{Development of protein paste}

After ISP recovery, the protein pellet $(750 \pm 17.8 \mathrm{gr})$ having an initial moisture of $870 \mathrm{~g}$ $\mathrm{kg}^{-1}$ confirmed by a moisture analyzer (Ohaus, Model MB45, Switzerland), was transferred to a universal food processor (model UMC5, Stephan Machinery Corp., Columbus, OH) and chopped at low speed for $1 \mathrm{~min}$, after which $0.20 \mathrm{~g} \mathrm{~kg}^{-1}$ salt was added and chopping was continued for an additional min. Chilled water $\left(4^{\circ} \mathrm{C}\right)$ was added to adjust the final moisture of the paste to $800 \mathrm{~g}$ $\mathrm{kg}^{-1}$. Standard functional additives including potato starch $\left(0.15 \mathrm{~g} \mathrm{~kg}^{-1}\right)$ (Penbind 1000 modified potato starch, Penford Food Ingredients Corp., Centennial, CO); polyphosphates (0.03 $\left.\mathrm{gr} \mathrm{kg}^{-1}\right)$ (Kena FP-28, Innophos, Cranbury, NJ) and transglutaminase (TGase) $\left(5 \mathrm{~g} \mathrm{~kg}^{-1}\right)$ were mixed in. The $\mathrm{pH}$ was adjusted to $\mathrm{pH} 7.0-7.2$ by adding $1 \mathrm{~mol} \mathrm{~L}^{-1} \mathrm{Ca}(\mathrm{OH})_{2}$. $\mathrm{HCl}$ was used for fine adjustments to stabilize $\mathrm{pH}$. Following confirmation of $\mathrm{pH}$, chopping was resumed for 3 min at 
high speed under vacuum $(50 \mathrm{kPa})$. The temperature of the universal food processor was adjusted, so that the protein paste was processed at $1-4^{\circ} \mathrm{C}$ during the paste development. Air pockets were removed from the paste prior to stuffing by vacuum packing. The vacuum-packed paste was then placed in a gel presser and stuffed into lightly oil-sprayed stainless steel tubes (length $=17.5 \mathrm{~cm}$, inner diameter $=1.9 \mathrm{~cm}$ ) and dumbbell shaped stainless steel torsion tubes (length $=17.5 \mathrm{~cm}$, end diameter $=1.9 \mathrm{~cm}$, midsection diameter $=1.0 \mathrm{~cm}$ ).

\subsection{Verification of recovered protein gelation properties}

Protein recovery using a $\mathrm{pH}$-shift method like ISP may induce changes in the native structure of the myofibrillar protein ${ }^{8}$. Therefore, the functional properties of the ISP-recovered protein was confirmed by measuring heat induced aggregation and denaturation of protein samples using differential scanning calorimetry (DSC; DSC Infinity Series F5010, Instrument Specialists, Inc., Spring Grove, IL). Fresh protein paste was spread onto an aluminum pan (Instrument Specialists Inc. $4 \mathrm{~mm}$ crimp/en cap), hermetically sealed and placed in the scanner. Temperature was increased from $5^{\circ} \mathrm{C}$ to $90^{\circ} \mathrm{C}$ at a rate of $10^{\circ} \mathrm{C} \min ^{-1}$. Data were analyzed using the DSC thermograms provided by the Infinite Software. DSC testing was performed in triplicates and results (net heat enthalpy, the onset and maximum temperatures) were presented as a mean. Results of DSC were compared to the fresh ground fish and Alaska Pollock surimi.

\subsection{Pre and Post-Cooking Timing Strategies}

Eight widely applied gelation conditions were selected to investigate the effects on the texture and color attributes. Three different time/temperature strategies for gel setting prior to cooking were tested: $30 \mathrm{~min}$ at room temperature $\left(25^{\circ} \mathrm{C}\right), 1 \mathrm{hr}$ at $40^{\circ} \mathrm{C}$ or $24 \mathrm{hr}$ at $4^{\circ} \mathrm{C}^{9-13}$. In addition, direct cooking (no waiting period) was applied as a control ${ }^{14}$. Two different post- 
cooking strategies were performed: no post-cooking waiting period (direct analysis) or storage for $24 \mathrm{~h}$ at $4^{\circ} \mathrm{C}$ prior to analysis.

\subsection{Preparation of the gels}

Following the pre-cooking gelation strategy, tubes were cooked at $90^{\circ} \mathrm{C}$ for $20 \mathrm{~min}$ in a water bath (Precision, Jouan Inc, Wincester, Virginia) and then chilled in an ice bath for 15 min. Depending on post-cooking strategy, the gels were either removed from the tubes and analyzed immediately or were stored in the tubes at $4^{\circ} \mathrm{C}$ for $24 \mathrm{~h}$. Prior to all analyses, gels were adjusted to room temperature $\left(25^{\circ} \mathrm{C}\right)$.

\subsection{Texture Profile Analysis (TPA)}

Texture profile analysis (TPA) was performed using a texture analyzer (Model TA-HDi, Texture Technologies Corp., Scarsdale, NY) with a $70 \mathrm{~mm}$ TPA compression plate attachment. Textural properties of hardness, springiness, cohesiveness, gumminess, chewiness and resilience were analyzed by Texture Expert software (Texture Expert Exceed version 2.64, Stable Micro Systems, 2003, Hamilton, MA, USA). At least 10 cylindrical gel samples (length $2.54 \mathrm{~cm}$, diameter $1.9 \mathrm{~cm}$ ) were tested per treatment.

\subsection{Kramer Shear Cell Test}

The Kramer shear cell test was applied to observe shear stress and shear force using a texture analyzer (Model TA-HDi, Texture Technologies Corp., Scarsdale, NY) with a Kramer cell attachment. The attachment had five blades ( $3 \mathrm{~mm}$ thick and $70 \mathrm{~mm}$ wide) that cut through the gel samples. The force ( $\mathrm{g}$ peak force $\mathrm{g}^{-1}$ gel sample) was measured at $127 \mathrm{~mm} \mathrm{~min}^{-1}$ crosshead speed and shear force was calculated by peak force divided by the weight of each sample. The shear stress was calculated as the force divided by the area of the sample. At least 6 cylindrical gel samples (length $8 \mathrm{~cm}$, diameter $1.9 \mathrm{~cm}$ ) per treatment were tested. Each gel 
sample was weighed prior to testing, and then placed in the Kramer cell of the texture analyzer. The shear force was calculated by dividing force by the weight of each sample; and the shear stress was calculated by dividing the force by the area of each sample.

\subsection{Torsion Analysis}

A torsion test was performed to measure shear stress and shear strain at mechanical fracture using a Hamman Gelometer (Gel Consultants, Raleigh, NC). At least 4 samples were tested for each treatment and the data was analyzed using Torsion Vane software (Gel Consultants, Raleigh, NC).

\subsection{Color analysis}

Color data was collected using a colorimeter (Minolta Camera Co. Ltd, Osaka, Japan) calibrated with a standard white plate No.21333180 (CIE L* 93.1; a* 0.3135; b* 0.3198). After L* (lightness; scale: 0 - 100), a* (intensity in red color; scale: $-60-+60$ ), and b* (intensity in yellow color; scale: -60 - +60) were measured, the whiteness was calculated using the following equation:

Whiteness $=100-\left[(100-L)^{2}+a^{2}+b^{2}\right]^{1 / 2}$

At least ten samples were used for color measurement per treatment and the results were given as a mean.

\subsection{Statistical Analysis}

The data retrieved from the analyses were presented as mean \pm SD. The treatments were randomized. Statistical analyses were run using JMP software (JMP 10, SAS Inst., Cary, NC, USA). Analysis of variance (ANOVA) and standard Least Squares (LS) were used. The mean values for each treatment were statistically separated and assigned a letter using Tukey's Honestly Significant Differences. Significance level was set at $0.05(\mathrm{p}<0.05)$. 
3. Results and Discussion

\subsection{Differential Scanning Calorimetry (DSC)}

A thermally-induced protein gel forms through denaturation, aggregation and eventually gelation. Differential scanning calorimetry (DSC) method provided insight into the stability of proteins by exploiting the unfolding and aggregation transitions through thermodynamic data ${ }^{15}$. Therefore, this method was used to confirm that the protein recovered using ISP process had similar gelation properties to Alaska Pollock surimi gel. Moreover, the functional properties of the ISP-recovered protein were also compared with the initial starting material, ground catfish. The results of DSC for the original ground catfish, Alaska Pollock surimi and the ISP-recovered protein pastes are shown in Figure 1. The curves for all three protein sources showed similar exothermic reactions ( $\mathrm{T}_{\text {onset, }} \mathrm{T}_{\max }$, and enthalpy). For the most part, there were no statistical differences $(\mathrm{p}>0.05)$ between the heat transaction properties of ground catfish, Alaska Pollock surimi and recovered catfish paste, which implies that the $\mathrm{pH}$ shifts to recover protein did not cause major losses in functionality.

Fish protein recovered by the ISP process mainly consists of myofibrillar protein (myosin, actin and actomyosin). Myosin is made up of a head, neck and tail region that partially unfolds when exposed to heat. This partial unfolding leads to irreversible aggregation of myosin heads to the binding sites on adjacent tails through disulfide bonds and hydrophobic interactions

1. This association of myosin heads occurs at a transition temperature between $27-46^{\circ} \mathrm{C}$ and is represented by Peak I on a DSC thermogram ${ }^{16,17}$. Figure 1 shows that the initial peak (I) of the protein paste had a transition temperature of $29.76 \pm 2.40^{\circ} \mathrm{C}$, reaching a $\mathrm{T}_{\max }$ of $53.23 \pm 4.39^{\circ} \mathrm{C}$ and an enthalpy of $0.48 \pm 0.19 \mathrm{~J}$ which is consistent with previously reported temperatures and enthalpies $^{17,18}$. 
The second peak (II) is attributed to the association of myosin tails which was observed at $46.17 \pm 5.42^{\circ} \mathrm{C}$ in our study (Figure 1). The third peak which had a $\mathrm{T}_{\text {onset }}$ of $66.17 \pm 5.64^{\circ} \mathrm{C}$ reflects actin association. Actin is relatively more heat stable compared to myosin and therefore, was denatured at a higher temperature ${ }^{17}$. In a previous study where silver carp protein was recovered using $\mathrm{NaOH}$ as the base, an enthalpy of 1.25 was measured for actin association ${ }^{17}$; whereas in this current study, the enthalpy was $2.59 \pm 0.75$. Addition of salt or treatment of either actomyosin or myofibrils with $\mathrm{NaCl}$ or $\mathrm{KCl}$ was reported to denature F-actin even at low temperatures ${ }^{19,20,21}$. Mineral analysis performed on ISP-recovered protein revealed that sodium levels were increased in the protein fraction when $\mathrm{NaOH}$ was used as the processing base ${ }^{22}$. Therefore, replacing $\mathrm{NaOH}$ with $\mathrm{Ca}(\mathrm{OH})_{2}$ may have decreased F-actin denaturation because the recovered protein would have less sodium.

\subsection{Texture Profile Analysis (TPA)}

Texture attributes (hardness, springiness, cohesiveness, gumminess, chewiness and resilience) of protein gels were assessed by TPA, an instrumental method involving two compression-decompression cycles (Figure 2). Gels were hardest $(\mathrm{p}<0.05)$, as measured by the peak force of the first compression, when there was no prior to and post-cooking gel-setting period (Figure 2). It was observed that gel hardness decreased as gels were allowed to set when they were directly analyzed; however, when there was a post-cooking $24 \mathrm{~h}$ storage period at $4^{\circ} \mathrm{C}$ prior to analyses, the hardness of gels benefited from a gel setting period. In general, gels got softer $(\mathrm{p}<0.05)$ when they were stored at $4^{\circ} \mathrm{C}$ for $24 \mathrm{~h}$ following cooking compared to direct analysis. Chewiness and gumminess, defined as the energy required to masticate a solid food and to disintegrate a semisolid food into a state of readiness for swallowing ${ }^{23}$ respectively, followed the same trend as hardness. Hardness, chewiness and gumminess of gels were lower when there 
was a post-cooking storage period regardless of the pre-cooking gel setting strategy suggesting protein degradation over time.

In the literature, most protein gels are made by combining concentrated protein with salt and then incubation below $40^{\circ} \mathrm{C}$ prior to cooking ${ }^{24,25}$. Typically, cooking pre-set gels yields harder gels when compared to gels cooked without a pre-cooking storage period ${ }^{5,26-28}$. Transglutaminase (TGase) (R-glutaminyl-peptide: amine g-glutamyltransferase; EC 2.3.2.13) is the major enzyme responsible for protein gels to set by activating myosin polymerization and $\mathcal{E}$ ( $\mathrm{y}_{\text {-glutamyl) lysine crosslinking }}{ }^{4,5,29-31}$. Fish muscle protein contains a high amount of endogenous TGase which is calcium dependent ${ }^{32}$. The recovered fish protein fraction contained an increased amount of calcium when $\mathrm{Ca}(\mathrm{OH})_{2}$ was used as the processing base during ISP compared to protein recovered using $\mathrm{NaOH}^{33}$. This may have led to an increased endogenous TGase activity. Moreover, microbial TGase (calcium independent) was added in the amount of 5 $\mathrm{g} / \mathrm{kg}$ protein paste, which likely resulted in additional TGase activity. This may have initially induced rapid gel setting as was observed in harder gels $(\mathrm{p}<0.05)$ that resulted when pastes were cooked without a gel-setting storage period.

Numerous pre-cooking time and temperature protein gelation strategies utilizing different protein sources have been reported in the literature, each with varying results. It is important to note that the species of fish will impact gelation characteristics. For example, silver carp protein gels were made using ISP-recovered protein ( $\mathrm{NaOH}$ was used as the processing base) and the same standard functional additives, with $24 \mathrm{~h}$ at $4^{\circ} \mathrm{C}$ pre-cooking storage followed by direct analysis ${ }^{13}$. The resulting gels were harder and had similar springiness, cohesiveness, resilience, gumminess and chewiness as the gels in this current study. In addition, gelation properties of protein gels made from Alaska Pollock, common carp, grass carp, and silver carp varied among 
species even when gels were exposed to the same heating strategies ${ }^{25}$. The same conclusion was made when textural properties of surimi produced from threadfin bream, big eye snapper, barracuda and big eye croaker were compared ${ }^{11}$. Therefore, differences in textural attributes may not only be due to calcium enhancement, but due to differences in fish species.

\subsection{Kramer Shear Cell Test}

Kramer shear cell test is commonly applied to food products to measure additional texture attributes such as shear stress which defines the strength of the product and shear force that gives an idea about the firmness and is a mechanical shearing procedure ${ }^{34}$. Kramer shear stress (Figure 3) was highest $(\mathrm{p}<0.05)$ when the gels were either directly cooked and stored for $24 \mathrm{~h}$ at $4^{\circ} \mathrm{C}$, or when they were allowed to set at $24 \mathrm{~h}$ at $4^{\circ} \mathrm{C}$ and directly analyzed. This shows that the catfish protein gel strength benefited from a gel setting or storage period for $24 \mathrm{~h}$ at $4^{\circ} \mathrm{C}$; therefore, as shown in another study, it is suggested that longer periods of gel setting at lower temperatures may allow for increased polymerization ${ }^{35}$. Interestingly, Kramer shear force was highest $(\mathrm{p}<0.05)$ either when a 30 min prior to cooking gel setting at room temperature and direct analysis, or a $24 \mathrm{~h}$ pre- and post-cooking storage at $4^{\circ} \mathrm{C}$ were performed (Figure 3). No precooking period or a short gel setting period $\left(30 \mathrm{~min}\right.$ at $\left.25^{\circ} \mathrm{C}\right)$ followed by an overnight preanalysis storage yielded the lowest $(\mathrm{p}<0.05)$ shear force. This is consistent with the TPA findings where the pre- and post-cooking strategies that yielded the highest $(\mathrm{p}<0.05)$ cohesiveness as well as the highest $(\mathrm{p}<0.05)$ shear force. Along with the same trend, the gel-setting strategy that yielded the lowest $(\mathrm{p}<0.05)$ shear force resulted in numerically the lowest hardness, gumminess and chewiness values. Therefore, when the cooked gels are going to be stored over a period of time, a gel setting period may be more beneficial.

\subsection{Torsion Test}


Torsion testing is a recommended standard for the surimi industry. Torsional stress and strain provide insight into the angular deformation resistance of gels. Specially molded, cylindrical, dumbbell shaped specimen breaks at mid-length where a fracture occurs while being twisted with both its upper and lower bases glued to plastic discs for attachment to the testing apparatus ${ }^{36}$. The stress and strain at fracture measured in this study are presented in Figure 3. Torsional stress at fracture was highest $(\mathrm{p}<0.05)$ when a $30 \mathrm{~min}$ at $25^{\circ} \mathrm{C}$ pre-cooking storage was performed followed by $24 \mathrm{~h}$ at $4^{\circ} \mathrm{C}$ post-cooking storage. The gels also benefited $(\mathrm{p}<0.05)$ from a gel setting period when they were direct analyzed and the highest $(\mathrm{p}<0.05)$ strain was measured when gel setting was applied for $24 \mathrm{~h}$ at $4^{\circ} \mathrm{C}$. Following a similar trend, strain was highest $(\mathrm{p}<0.05)$ when either a $24 \mathrm{~h}$ at $4^{\circ} \mathrm{C}$ pre-cooking period followed by direct analysis or a $30 \mathrm{~min}$ at $25^{\circ} \mathrm{C}$ pre-cooking storage followed by $24 \mathrm{~h}$ at $4^{\circ} \mathrm{C}$ post-cooking storage was applied. These findings are in line with what was observed by TPA and Kramer shear cell analyses. Therefore, it can be concluded that the ISP-recovered catfish protein used in this study may benefit from a pre-cooking gel-setting period either at $25^{\circ} \mathrm{C}$ or at $4^{\circ} \mathrm{C}$. Pre-cooking gel setting strategies are usually performed at three different temperature classifications: low $\left(0-4^{\circ} \mathrm{C}\right)$, medium $\left(25^{\circ} \mathrm{C}\right)$ or high $\left(40^{\circ} \mathrm{C}\right)$ temperatures ${ }^{37}$. The textural properties attained by gel setting at different temperatures will differ depending on which fish species is used as the protein source ${ }^{11}$. Although lower temperatures require longer gel-setting periods for gel setting to be complete, lower temperatures induce less protein degradation by proteinases ${ }^{11}$. Medium or low temperature pre-cooking storage may result in better textural measurements due to lower proteolysis and degradation.

\subsection{Color Measurement}


Color was measured using a colorimeter and the measurements for $\mathrm{L}^{*}$ (lightness), $\mathrm{a}^{*}$ (intensity in red color; scale), and b* (intensity in yellow color). When $24 \mathrm{~h}$ pre-cooking period at $4^{\circ} \mathrm{C}$ followed by a $24 \mathrm{~h}$ storage at $4^{\circ} \mathrm{C}$ was applied, gels were the reddest $(\mathrm{p}<0.05)$ and least yellow $(\mathrm{p}<0.05)($ Table 1$)$ suggesting that a prolonged pre- and post-cooking storage at low temperature preserves color properties of the protein gel. On the other hand, gels were darkest $(\mathrm{p}<0.05)$ when a $24 \mathrm{~h}$ at $4^{\circ} \mathrm{C}$ pre-cooking period was followed by $24 \mathrm{~h}$ at $4^{\circ} \mathrm{C}$ post-cooking storage period was applied. Cohesiveness was highest with prolonged gel-setting period at low temperature thus the darker color may be due to denser myofibrillar gel matrix ${ }^{38}$. Moreover, longer storage periods may accelerate auto-oxidation of myoglobin. Gels were lightest $(\mathrm{p}<0.05)$ when there was no pre-cooking period followed by a $24 \mathrm{~h}$ post-cooking storage at $4^{\circ} \mathrm{C}$. Overall, looking at the pre-cooking gel-setting strategies, it was observed that as pre-cooking storage time increased, lightness decreased $(\mathrm{p}<0.05)$. The increase and decrease in lightness of protein gels differ depending on the structure the protein gel matrix and the size of scattering particles ${ }^{39}$. Whiteness is an important aspect that determines consumer acceptability of the end product. The values for whiteness (Figure 4) ranged from 58.2 to 72.7 and these measurements were similar to or whiter than gels from previous research where the protein gels were from isoelectrically recovered silver carp using $\mathrm{NaOH}$ and the addition of $5 \mathrm{~g}$ titanium dioxide $/ \mathrm{kg}$ protein paste, a commonly used whitening agent in food products ${ }^{13,40}$. Titanium dioxide was not used in this current study and the high whiteness of the gels are likely due to the whitening effect of $\mathrm{Ca}(\mathrm{OH})_{2}$ used during ISP processing. The protein fraction was determined to contain an increased amount of $\mathrm{Ca}$ when processed with $\mathrm{Ca}(\mathrm{OH})_{2}$ during protein recovery ${ }^{33}$. Therefore, the protein gels made with this recovered protein contained a higher calcium amount trapped in the gel matrix compared to gels made with protein recovered using $\mathrm{NaOH}$ as the processing base. 
The increased calcium may have inhibited the reaction between tyrosinase and its phenolic components; therefore, decreasing browning ${ }^{41}$. Moreover, calcium particles are white and water soluble. In the gels, the calcium particles will have solubilized in water, and mixed in the gel to make it whiter. This suggests that calcium enhanced products have the potential to improve whiteness of products without the need for additional whitening agents.

\section{Conclusion}

Although textural properties such as hardness, chewiness and gumminess were higher when either direct cooking or a short period of prior to cooking gel-setting period was applied; cohesiveness and gel firmness benefited from longer storage period at low $\left(4^{\circ} \mathrm{C}\right)$ and medium temperatures $\left(25^{\circ} \mathrm{C}\right)$. Calcium content of the recovered catfish protein gels may have played a role in rapid gel formation; however, future studies are necessary to determine if the gel strength was reflecting aggregate formation or protein polymerization. Additionally, gels were harder, chewier, gummier and more resilient to axial deformation when they were allowed to set for either $30 \mathrm{~min}$ at $25^{\circ} \mathrm{C}$ or $24 \mathrm{~h}$ at $4^{\circ} \mathrm{C}$ followed by a storage period $\left(24 \mathrm{~h}\right.$ at $\left.4^{\circ} \mathrm{C}\right)$ post-cooking; therefore, gel setting may be required for products that will be stored over time. Whiteness of the gels decreased as the duration of storage increased. Overall, protein gel characteristics were greatly affected by prior and post-cooking storage temperature and time. Therefore, pre- and post-cooking storage conditions must be carefully selected depending on the expected gel properties.

\section{Acknowledgements}

This work was funded by the HATCH Program Project \# (WVA 00622). 


\section{References}

1 Sun XD and Holley RA, Factors influencing gel formation by myofibrillar proteins in muscle foods. Compr Rev Food Sci F 10(1): 33-51 (2011).

2 Boye JI, Alli I, Ismail AA, Gibbs BF and Konish Y, Factors affecting molecular characteristics of whey protein gelation. Int Dairy J 5: 337-353 (1995).

3 Catsimpoolas N and Meyer EW, Gelation phenomena of soybean globulins: protein-protein interactions. Cereal Chem 47: 559-570 (1970).

4 Lee HG, Lanier TC, Hamann DD and Knopp JA, Transglutaminase effects on low temperature gelation of fish protein sols. J Food Sci 62(1): 20-24 (1997).

5 Kamath GG, Lanier TC, Foegeding EA and Hamman DD, Nondisulfide covalent cross-linking of myosin heavy chain in setting of Alaska pollock and Atlantic croaker surimi. J Food Biochem 16: 151-172 (1992).

6 Ramírez JA, Rodrígues-Sosa R, Morales OG and Vázquez M, Surimi gels from striped mullet (Mugil cephalus) employing microbial transglutaminase. Food Chem 70: 443-449 (2000).

7 Aguilera JM, Protein gels, in Proteins in food processing, ed by Yada RY. Taylor \& Francis, Woodhead Publishing LTD and CRC Press LLC, Roca Raton, FL, pp 468-480 (2004).

8 Gehring CK, Gigliotti JC, Moritz JS, Tou JC and Jaczynski J, Functional and nutritional characteristics of proteins and lipids recovered by isoelectric processing of fish byproducts and low-value fish: A review. Food Chem 124: 422-431 (2011).

9 Alvarez C, Couso I and Tejada M, Sardine surimi gels as affected by salt concentration, blending, heat treatment and moisture. J Food Sci 60(3): 622-626 (1995).

10 Park JW, Yongsawatdigul J and Lin TM, Rheological behavior and potential cross-linking of Pacific whiting (Merluccius productus) surimi gel. J Food Sci 59(4): 773-776 (1994). 
11 Benjakul S, Chantarasuwan C and Visessanguan W, Effect of medium temperature setting on gelling characteristics of surimi from some tropical fish. Food Chem 82: 567-574 (2003).

12 Ramírez JA, Ángel AD, Uresti RM, Velazquez G and Vázquez M, Low-salt restructured products from striped mullet (Mugil cephalus) using microbial transglutaminase or whey protein concentrate as additives. Food Chem 102: 243-249 (2007).

13 Paker I, Beamer S, Jaczynski J and Matak KE, pH shift protein recovery with organic acids on texture and color of cooked gels. J Sci Food Agr DOI: 10.1002/jsfa.6712 (2014).

14 Benjakul S, Visessanguan W, Riebroy S, Ishizaki S and Tanaka M, Gel-forming properties of surimi produced from bigeye snapper, Priacanthus tayenus and $P$ macracanthus, stored in ice. J Sci Food Agr 82(13): 1442-1451 (2002).

15 Spink CH, Differential scanning calorimetry. Method Cell Biol 84: 115-141 (2008).

16 Egelandsdal B, Fretheim K and Samejima K, Dynamic rheological measurements on heatinduced myosin gels: effect of ionic strength, protein concentration and addition of adenosine triphosphate or pyrophosphate. J Sci Food Agr 37: 915-926 (1986).

17 Paker I, Beamer S, Jaczynski J and Matak KE, The effect of organic acids on gelation characteristics of protein gels made from silver carp (Hypophthalmichthys molitrix) protein recovered by isoelectric solubilization and precipitation. LWT-Food Sci Technol 53: $37-43$ (2013).

18 Taskaya L, Chen YC and Jaczynski J, Functional properties of proteins recovered from silver carp (Hypophthalmichthys molitrix) by isoelectric solubilization/precipitation. LWT-Food Sci Technol 42: 1082-1089 (2009).

19 Wakameda A, Nozawa S and Arai K, Effect of neutral salts on thermal denaturation of myofibrillar Ca-ATPase of fish. Nippon Suisan Gakk 49: 237-243 (1983). 
20 Wakameda A and Arai K, The denaturation mechanism of carp myosin B in the presence of high concentration of salt. Nippon Suisan Gakk 50: 635-643 (1984).

21 Kuwahara K and Konno K, Suppression of thermal denaturation of myosin and salt-induced denaturation of actin by sodium citrate in carp (Cyprinus carpio). Food Chem 122: 997$1002(2010)$.

22 Paker I, Beamer S, Jaczynski J and Matak KE, Compositional characteristics of materials recovered from headed gutted silver carp (Hypophthalmichthys molitrix) by isoelectric solubilization and precipitation using organic acids. J Food Sci 78(3): E445-451 (2013).

23 Szczesniak AS, Classification of textural characteristics. J Food Sci 28(4): 385-389 (1963).

24 Totosaus A, Montejano JG, Salazar JA and Guerrero I, A review of physical and chemical protein-gel induction. Int J Food Sci Tech 37: 589-601 (2002).

25 Luo YK, Kuwahara R, Kaneniwa M, Murata Y and Yokoyama M, Comparison of gel properties of surimi from Alaska pollock and three freshwater fish species: effects of thermal processing and protein concentration. J Food Sci 66(4): 548-554 (2001).

26 Okada M, Application of setting phenomenon for improving the quality of kamaboko. Bull Tokai Reg Fish Res 24: 67-72 (1959).

27 Niwa E and Nakajima G, Difference in protein structure between elastic kamaboko and brittle one. Bull Jap Soc Sci Fish 41: 579-582 (1975).

28 Lanier TC, Functional properties of surimi. J Food Technol 3: 107-114 (1986).

29 Seki N, Uno H, Lee NH, Kimura I, Toyoda K, Fujita T and Arai K, Transglutaminase activity in Alaska pollock muscle and surimi, and its reaction with myosin B. Nippon Suisan Gakk 56: 125-132 (1990). 
30 Kumazawa Y, Seguro K, Takamura M and Motoki M, Formation of $\varepsilon$-( $\gamma$-Glutamyl) lysine cross-link in cured horse mackerel meat induced by drying. J Food Sci 58: 1062-1064 (1993).

31 Kimura I, Sugimoto M, Toyoda K, Seki N, Arai KI and Fujita T, A study on the cross-linking reaction of myosin in kamaboko Suwari gels. Nippon Suisan Gakk 57(7): 1389-1396 (1991).

32 Kuraishi C, Yamazaki K and Susa Y, Transglutaminase: its utilization in the food industry. Food Rev Int 17(2): 221-246 (2001).

33 Paker I, Matak KE, Efficacy of $\mathrm{Ca}(\mathrm{OH})_{2}$ as a potential base in $\mathrm{pH}$ shift recovery, Chapter 1, Paker I, Master's Thesis, Animal and Nutritional Sciences, West Virginia University (2015).

34 Brewer S, Quality measurements in beef, in Handbook of meat, poultry and seafood quality, $2^{\text {nd }}$ edition, ed by Nollet NML, assoc eds Boylston T, Chen F, Coggins PC, Hyldig G, McKee LH and Kerth CR. John Wiley \& Sons Inc: Ames, Iowa, pp 208-231 (2012).

35 Lee SK and Min BJ, Effect of setting temperatures and time on the gelation properties (suwari and modori phenomena) of surimi from mechanically deboned chicken meat. Asian Austral J Anim 17(12): 1758-1763 (2004).

36 Hamann DD, Zhang J, Christopher R D, Allen FE and Kenneth C D, Analysis of compression, tension and torsion for testing food gel fracture properties. J Texture Stud 37(6): 620-639 (2006).

37 Lanier TC, Measurement of surimi composition and functional properties, in Surimi technology, ed by Lanier TC and Lee CM. Marcel Dekker, Inc, New York, pp 123-166 (1992). 
38 Chanarat S and Benjakul S, Impact of microbial transglutaminase on gelling properties of Indian mackerel fish protein isolates. Food Chem 136: 929-937 (2013).

39 Kang G, Yang H, Jeong J, Moon S, Hur S, Park G and Joo S, Gel color and texture of surimilike pork from muscles at different rigor states post-mortem. Asian Austral J Anim 20(7): 1127-1134 (2007).

40 Taskaya L, Chen YC and Jaczynski J, Color improvement by titanium dioxide and its effect on gelation and texture of proteins recovered from whole fish using isoelectric solubilization/precipitation. LWT-Food Sci Technol 43: 401-408 (2010).

41 Kukura JL, Beelman RB, Peiffer M, Walsh R, Calcium chloride added to irrigation water of mushrooms (Agaricus bisporus) reduces postharvest browning. J Food Sci 63:454-457 (1998). 


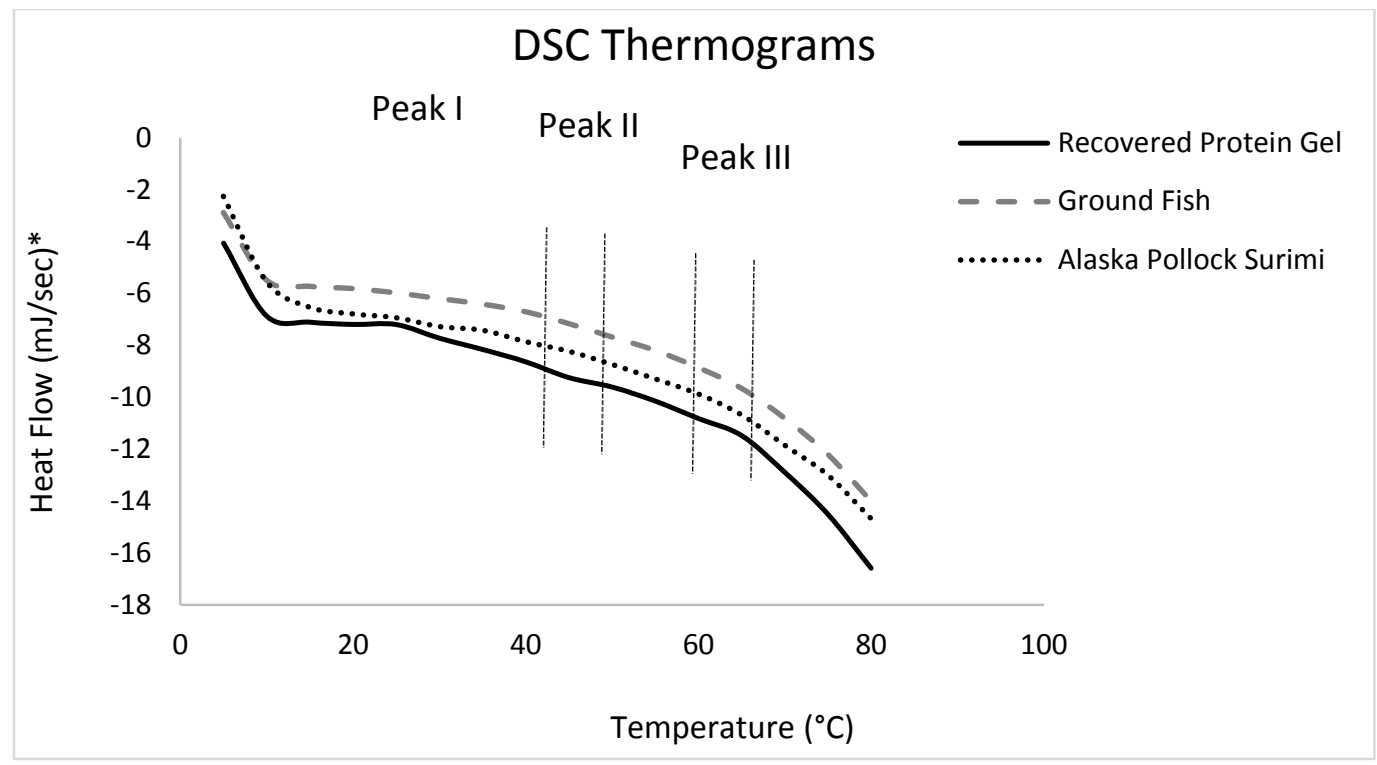

Figure 1. Differential scanning calorimetry (DSC) thermograms of isoelectrically recovered black bullhead catfish protein paste, Alaska Pollock surimi and initial ground black bullhead catfish. Each curve was drawn using the mean of data points collected from 3 replications. 


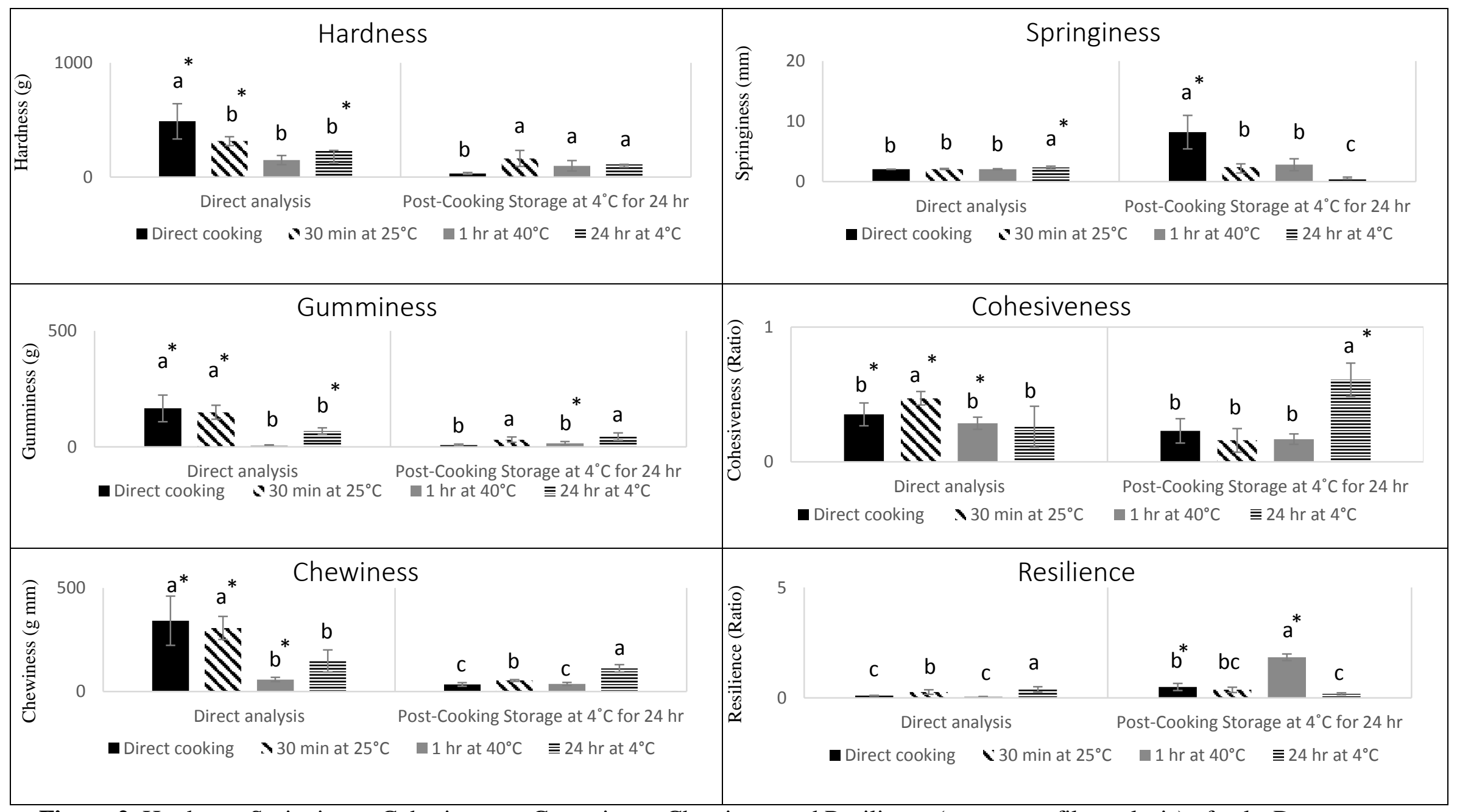

Figure 2. Hardness, Springiness, Cohesiveness, Gumminess, Chewiness and Resilience (texture profile analysis) of gels. Data are given as mean \pm standard deviation. ${ }^{\mathrm{a}, \mathrm{b}, \mathrm{c}}$ Mean values with different letters in each post cooking storage application are significantly different (Tukey's honestly significant differences test, $\mathrm{p}<0.05$ ). Significant differences (one way ANOVA test, $\mathrm{p}<0.05$ ) between the same pre-cooking gel setting treatments are indicated with an *. 


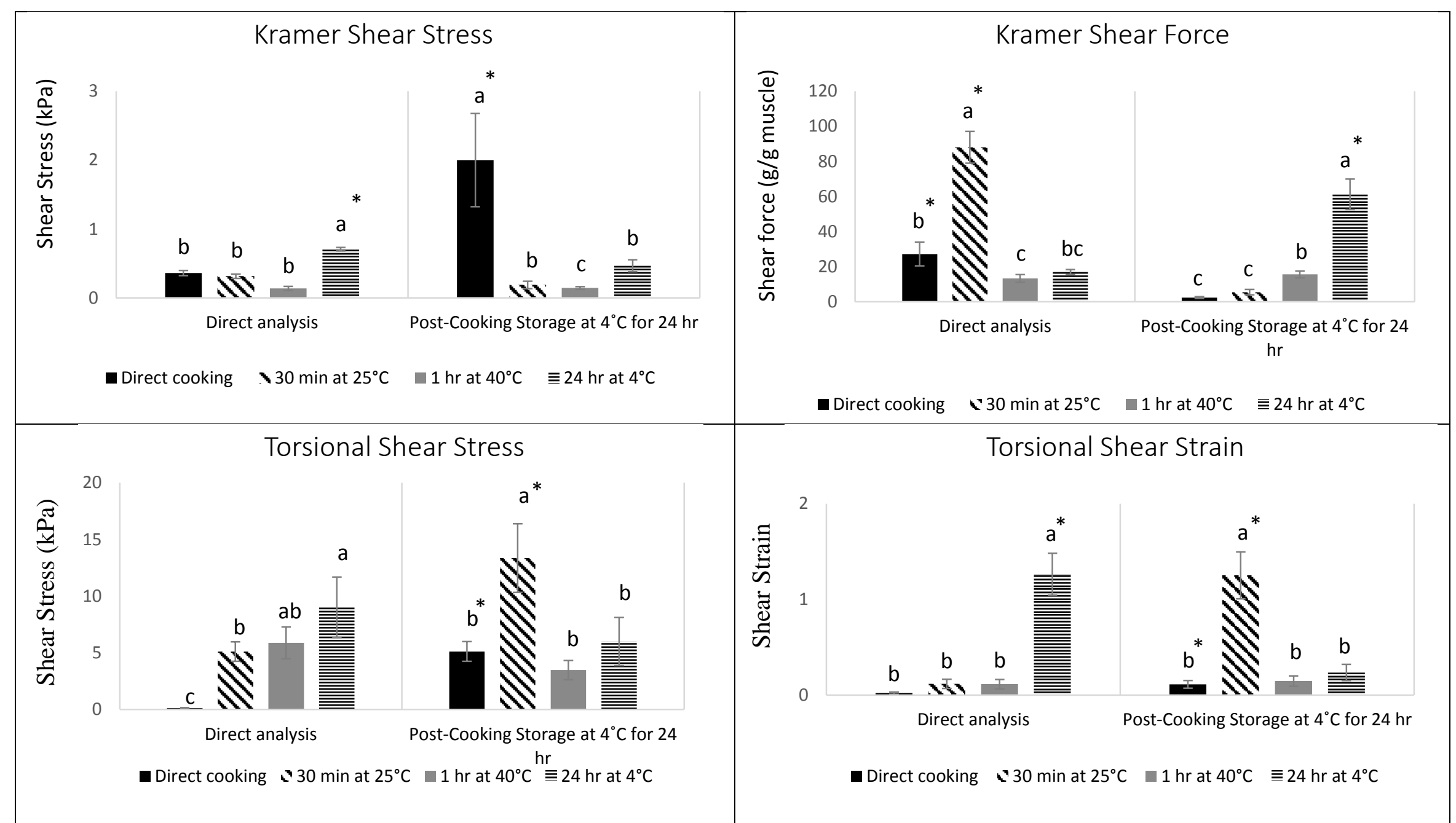

Figure 3. Kramer shear stress (kPa), Kramer shear force (g/g muscle), torsional shear stress (kPa) and torsional shear strain of recovered black catfish protein gels. Data are given as mean \pm standard deviation. ${ }^{\mathrm{a}, \mathrm{b}, \mathrm{c}}$ Mean values with different letters in each post cooking storage application are significantly different (Tukey's honestly significant differences test, $\mathrm{p}<0.05$ ). Significant differences (one way ANOVA test, $\mathrm{p}<0.05$ ) between the same pre-cooking gel setting treatments are indicated with an *. 
Whiteness

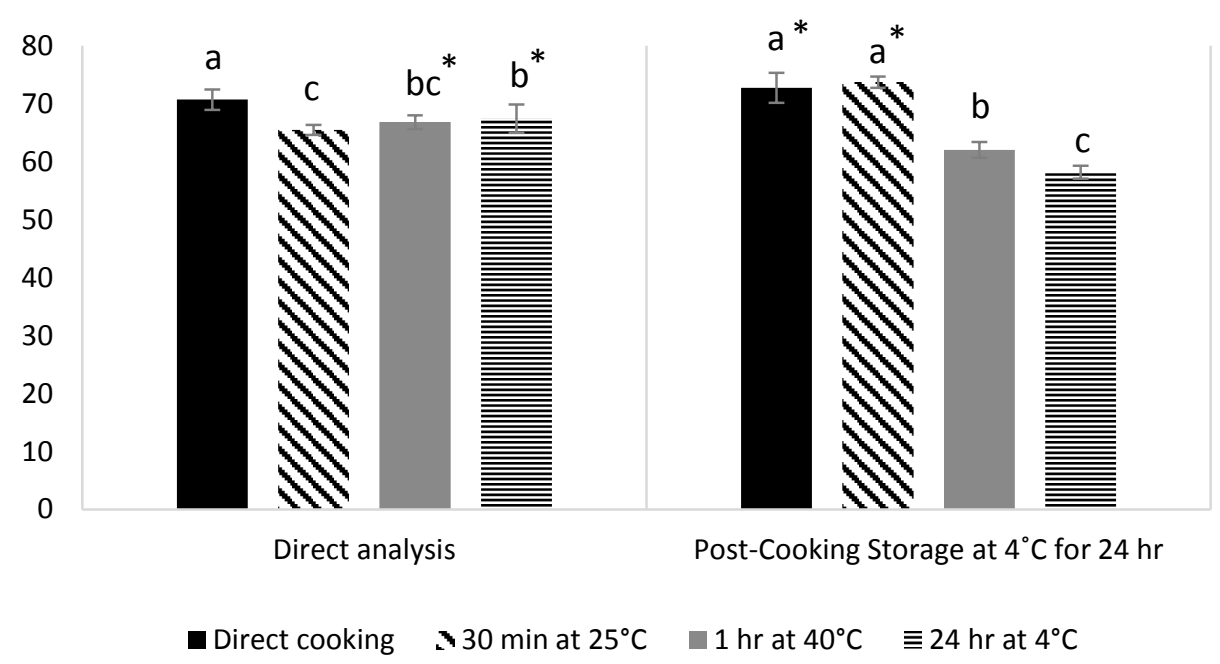

Figure 4. Whiteness of recovered black catfish protein gels. Data are given as mean \pm standard deviation. ${ }^{\mathrm{a}, \mathrm{b}, \mathrm{c}}$ Mean values with different letters in each post cooking storage application are significantly different (Tukey's honestly significant differences test, $\mathrm{p}<0.05$ ). Significant differences (one way ANOVA test, $\mathrm{p}<0.05$ ) between the same pre-cooking gel setting treatments are indicated with an *. 
Table 1. Color properties of recovered black catfish protein gels, where $\mathrm{L}^{*}$ indicates lightness (scale: $0-100$ ), $\mathrm{a}^{*}$ measures the intensity of red color (scale: -60 to +60 ), and $b^{*}$ shows the intensity of yellow color (scale: -60 to +60$)^{13}$. Data are given as mean \pm standard deviation. . ${ }^{\mathrm{a}, \mathrm{b}, \mathrm{c}, \mathrm{d}}$ Mean values with different letters in each post cooking storage application are significantly different (Tukey's honestly significant differences test, $p<0.05$ ). Significant differences (one way ANOVA test, $p<0.05$ ) between the same precooking gel setting treatments are indicated with bold numbers.

\begin{tabular}{|c|c|c|c|c|}
\hline Pre-cooking Gel Setting & Post-Cooking Storage & $\mathbf{L} *$ & $a^{*}$ & $\mathbf{b}^{*}$ \\
\hline Direct cooking & Direct analysis & $74.18 \pm 1.66 \mathrm{a}$ & $0.6 \pm 0.2 \mathrm{~b}$ & $13.82 \pm 0.99 \mathrm{a}$ \\
\hline $30 \mathrm{~min}$ at $25^{\circ} \mathrm{C}$ & Direct analysis & $66.85 \pm 0.83 \mathrm{c}$ & $1.6 \pm 0.26 \mathrm{a}$ & $9.41 \pm 0.54 \mathrm{c}$ \\
\hline $1 \mathrm{~h}$ at $40^{\circ} \mathrm{C}$ & Direct analysis & $69.04 \pm 1.32$ b & $0.03 \pm 0.01 \mathrm{c}$ & $11.82 \pm 1.43 \mathrm{~b}$ \\
\hline $24 \mathrm{~h}$ at $4^{\circ} \mathrm{C}$ & Direct analysis & $68.23 \pm 2.19 b$ & $-0.33 \pm 0.14 d$ & $7.19 \pm 1.45 \mathrm{~d}$ \\
\hline Direct cooking & $24 \mathrm{~h}$ at $4^{\circ} \mathrm{C}$ & $78.52 \pm 3.28 \mathrm{a}$ & $-6.35 \pm 0.81 c$ & $15.28 \pm 2.01 \mathrm{a}$ \\
\hline $30 \mathrm{~min}$ at $25^{\circ} \mathrm{C}$ & $24 \mathrm{~h}$ at $4^{\circ} \mathrm{C}$ & $75.26 \pm 1.14 b$ & $-2.00 \pm 0.22 b$ & $8.50 \pm 0.91 \mathrm{~b}$ \\
\hline $1 \mathrm{~h}$ at $40^{\circ} \mathrm{C}$ & $24 \mathrm{~h}$ at $4^{\circ} \mathrm{C}$ & $65.22 \pm 1.39 \mathrm{c}$ & $-1.87 \pm 0.83 b$ & $14.98 \pm 1.12 \mathrm{a}$ \\
\hline $24 \mathrm{~h}$ at $4^{\circ} \mathrm{C}$ & $24 \mathrm{~h}$ at $4^{\circ} \mathrm{C}$ & $60.82 \pm 1.86 \mathrm{~d}$ & $2.49 \pm 1.02 \mathrm{a}$ & $13.84 \pm 3.58 \mathrm{a}$ \\
\hline
\end{tabular}




\title{
CHAPTER 4
}

\section{Impact of Sarcoplasmic Proteins on Texture and Color of Silver Carp and Alaska Pollock Protein Gels}

\begin{abstract}
Isoelectric solubilization and precipitation (ISP) relies on extreme $\mathrm{pH}$ shifts to solubilize, precipitate and recover myofibrillar protein (MP), whereas sarcoplasmic proteins (SP) are water soluble. SP were recovered from silver carp (SC) and added to ISP-recovered SC MP or Alaska Pollock (AP) to investigate the impact on texture and color of their cooked gels. MP was solubilized at $\mathrm{pH} 12.3$ using $\mathrm{Ca}(\mathrm{OH})_{2}$ and precipitated at $\mathrm{pH} 5.5$ with acetic acid. Protein (ISP recovered SC MP or AP) was combined with transglutaminase (TGase) at 0 or $5 \mathrm{~g}$, starch at 15 or $20 \mathrm{~g}$, polyphosphates at $3 \mathrm{~g}$, and SP at $0,77 \mathrm{mg}$ or $144 \mathrm{mg}$ per $\mathrm{kg}$ final protein gel paste. Gels without added SP (5g TGase only) were harder, gummier, chewier, more cohesive and resilient ( $\mathrm{p}<0.05)$, for both SC and AP. Interestingly, addition of SP in SC gels showed similar results as adding 5g TGase for some textural measurements, including springiness and Kramer and Torsional stress $(\mathrm{p}>0.05)$. This was likely due to the calcium content and endogenous TGase activity in ISP-recovered protein. Future studies comparing effects of SP and endogenous TGase on protein gels with different calcium content would be beneficial.
\end{abstract}

Key Words: pH shift, sarcoplasmic proteins, calcium hydroxide, texture, color Chemical compounds studied in this article Calcium hydroxide (PubChem CID: 6093208); Acetic acid (PubChem CID: 176) 
Introduction

The traditional surimi making process involves continuous washing of fish flesh with chilled water to separate fractions that interfere with gelation such as blood, connective tissue and the less desirable, water-soluble sarcoplasmic proteins from the high quality myofibrillar protein (MP) (Hall \& Ahmad, 1997). A high concentration of MP is preferred for making protein gels since it improves gelation properties in fish protein gels (Okada, 1964; Nakayama \& Sato, 1971; Nakagawa et al., 1989). This is mainly due to myosin and actomyosin being the predominant proteins responsible for protein gelation (Stone \& Stanley, 1992). However, functional additives such as potato starch, transglutaminase (TGase), polyphosphates and titanium dioxide that enhance protein gelation and color are frequently used for developing marketable protein gels especially when isoelectrically recovered protein is used (Taskaya et al., 2009).

Isoelectric solubilization and precipitation (ISP) is an acid/alkali-aided protein recovery process that relies on $\mathrm{pH}$ shifts to separate protein from the lipid and insoluble fractions of fish. The traditional acid used in ISP is hydrochloric acid $(\mathrm{HCl})$; however, researchers have demonstrated that using organic acids may have bactericidal effects (Otto et al., 2011a,b). The traditional processing base used in ISP is sodium hydroxide $(\mathrm{NaOH})$ which increases the sodium content of the recovered protein fraction (Paker et al., 2013a). Therefore, using an alternative processing base may reduce sodium content in the recovered protein. To date, there are no reported studies where calcium hydroxide $\left(\mathrm{Ca}(\mathrm{OH})_{2}\right)$ is used as the processing base for ISP processing. Replacing $\mathrm{NaOH}$ with $\mathrm{Ca}(\mathrm{OH})_{2}$, a widely used fortifier and whitening agent in the food industry (Han et al., 2012), may yield a final product that has more calcium and also eliminate the need to use titanium dioxide as a whitening agent during protein gel making. 
As with surimi processing, protein recovered by ISP processing is mainly MP and it exhibits similar functionality as traditional surimi gels (Taskaya et al., 2009; Paker et al., 2013b). In both of these recovery processes, sarcoplasmic proteins are typically discarded with the process water; however, the potential of sarcoplasmic proteins as a functional ingredient has not been thoroughly explored. Sarcoplasmic proteins may impact gel formation and texture properties of protein gels by stimulating the setting effect of MP (Yongsawatdigul \& Piyadhammaviboon, 2007). Therefore, if the otherwise discarded sarcoplasmic proteins are recovered from the process water it may have potential as an additive.

Transglutaminase (EC 2.3.2.13; TGase), the major functional additive that enhances gel network formation, is an enzyme that catalyzes an acyl-transfer reaction and in turn activates invitro cross-linking in actomysin (Zhu et al., 1995). Commercial TGase is either recovered from animal tissue or isolated from microbial fermentation. Researchers have measured a substantial amount of TGase activity in fish tissue (Yasueda et al., 1994; Worratao \& Yongsawatdigul, 2005) as well as significant amount of TGase in the wash water of surimi (Yongsawatdigul et al., 2002). It is possible that endogenous TGase would be recovered with sarcoplasmic proteins and would work synergistically as gel enhancers (Yongsawatdigul \& Piyadhammaviboon, 2007). Sarcoplasmic protein was previously lyophilized and incorporated into protein gels; however, low amounts $(0.01 \mathrm{~g} / \mathrm{kg})$ of sarcoplasmic protein powder were not effective in increasing gel strength (Hemung \& Chin, 2013). Freeze-drying may induce structural changes in sarcoplasmic protein. Therefore, the purpose of this study was to investigate the impact of added sarcoplasmic proteins as an aqueous solution in order to avoid confirmation change on the textural properties of isoelectrically recovered silver carp MP or Alaska Pollock (AP) surimi gels.

2. Materials and Methods 


\subsection{Preparation of fresh headed gutted silver carp}

Wild caught silver carp (SC) (Hypophthalmichthys molitrix) purchased from Fin International LLC (NewOrleans, LA, USA) were shipped overnight on ice to the meats processing laboratory at West Virginia University. The fish were headed, gutted and sanitized by dipping into a 50mg/kg bleach solution for $10 \mathrm{~s}$ (Clorox Regular Bleach, Clorox, Oakland, CA, USA). The fish were then drained and ground using a sanitized food processor (HobartModel 4146, Troy, OH, USA) using a coarse and fine plate. Finally, the ground fish paste (215 g) was packed into freezer bags (Ziplock Freezer Bags, S.C. Johnson \& Son, Inc., Racine, WI, USA), vacuum packaged (Ultravac KOCH Packaging, KOCH Supplies Inc., Kansas City, MO, USA) and stored at $-80^{\circ} \mathrm{C}$. All equipment used in the experiments were sanitized using a $70 \mathrm{ml} / 100 \mathrm{ml}$ ethanol spray and drying under UV light (254 nm) for 15 min (Otto et al. 2011a).

\subsection{Alaska Pollock surimi}

Alaska Pollock (Theragra chalcogramma) caught by pelagic trawl at the Northeast Pacific Ocean was purchased as a frozen block of surimi. The surimi block contained Alaska Pollock incorporated with sorbitol, sugar, sodium tripolyphosphate, and tetrasodium pyrophosphate. Alaska Pollock surimi is known as having the most preferred textural attributes in the reconstructed aquatic products industry. Therefore, it was selected to compare the textural differences between isoelectrically recovered silver carp and a product that was accepted in the fish products industry. Moreover, effects of sarcoplasmic protein addition in Alaska Pollock surimi were assessed in order to determine if the extensive washing cycles are necessary to achieve certain gel strength.

2.3. Recovery of sarcoplasmic proteins 
Thawed $\left(24 \mathrm{~h}\right.$ at $\left.4^{\circ} \mathrm{C}\right)$ ground fish paste was diluted with distilled, deionized water at a 1:2 ratio in a glass beaker using a homogenizer (PowerGen 700, Fisher Scientific, Pittsburgh, PA). Homogenization was continued for 10 min to allow for solubilization of the sarcoplasmic proteins. The solution was then transferred into centrifuge bottles and centrifuged at $10,000 \mathrm{xg}$ for $15 \mathrm{~min}$ at $4^{\circ} \mathrm{C}$. The solubilized sarcoplasmic proteins were poured off the remaining fish pellet into a glass beaker, covered with foil, and stored at $4^{\circ} \mathrm{C}$ for $24 \mathrm{~h}$. After 24 hours, the solution of sarcoplasmic proteins was taken out of the refrigerator, filtered through cheese cloth and collected in a glass bottle to be used immediately. The amount of sarcoplasmic proteins in the solution was $55.7 \pm 4.6 \mathrm{mg} / 100 \mathrm{ml}$ as determined using Bradford Protein Assay (Bio-Rad Laboratories, Inc., CA) with bovine serum albumin as the standard.

2.4. Isoelectric solubilization and precipitation (ISP)

After the sarcoplasmic proteins were removed by solubilization, the remaining fish paste pellet containing mainly myofibrillar silver carp protein and other insoluble fractions (i.e. skin, bones, etc.) was diluted with distilled, deionized water at a 1:6 dilution ratio in a glass beaker using a homogenizer (PowerGen 700, Fisher Scientific, Pittsburgh, PA). After the pH was adjusted to and stabilized at pH 12.3 using $1 \mathrm{~mol}$ equi/L Ca(OH) $($ Fisher Scientific, Fair Lawn, NJ, USA) for MP solubilization, homogenization continued for an additional $5 \mathrm{~min}$. The homogenate was then transferred into centrifuge bottles and centrifuged at 10,000 x $\mathrm{g}$ for $15 \mathrm{~min}$ at $4{ }^{\circ} \mathrm{C}$ (Sorvall RC-SB Refrigerated Superspeed Centrifuge, Du Pont, Wilmington, DE, USA) to separate insoluble (bones, skin, scales, etc.) and lipids from the protein and process water. After centrifugation, the lipids and insoluble components were removed from the supernatant containing mostly solubilized protein by filtration through a cheese cloth. Glacial acetic acid (AA) (Fisher Scientific, Fair Lawn, NJ, USA) was used to return the $\mathrm{pH}$ to 5.5, the isoelectric 
point of the protein for protein precipitation. Homogenization continued for an additional 5 min at protein isoelectric point. The homogenate was then centrifuged at $10,000 \mathrm{x} \mathrm{g}$ for $15 \mathrm{~min}$ at $4^{\circ} \mathrm{C}$ for protein recovery. The recovered protein was collected and stored at $4{ }^{\circ} \mathrm{C}$ following centrifugation.

2.5. Protein paste development

Protein pastes were developed as described previously (Paker et al., 2013b, 2014). A universal food processor (model UMC5, Stephan Machinery Corp., Columbus, OH) was used to chop and mix the recovered SC protein or thawed AP at low speed for 5 min with functional additives such as $(20 \mathrm{~g} / \mathrm{kg})$ salt, $(15-20 \mathrm{~g} / \mathrm{kg})$ potato starch (Penbind 1000 modified potato starch, Penford Food Ingredients Corp., Centennial, CO), (3g/kg) polyphosphate (Kena FP-28, Innophos, Cranbury, $\mathrm{NJ}),(0-144 \mathrm{mg} / \mathrm{kg})$ sarcoplasmic proteins solution and $(0-5 \mathrm{~g} / \mathrm{kg})$ TGase (Activa GS 100, Ajinomoto Inc., Tokyo, Japan) depending on the treatment. The ingredients and the amounts used in protein paste development are presented in Table 1. Each treatment was designed so that the total functional additives would add to the standard amount of $23 \mathrm{~g} / \mathrm{kg}$ of gel composition used in previous studies (Taskaya et al., 2009; Paker et al., 2013b). The temperature of the food processor was adjusted to $-10^{\circ} \mathrm{C}$ so that the protein temperature would not go over $4^{\circ} \mathrm{C}$ throughout the process. The final moisture was set to $820 \mathrm{~g} / \mathrm{kg}$ (confirmed by a moisture analyzer) using either chilled $\left(4^{\circ} \mathrm{C}\right)$ distilled water or a chilled $\left(4^{\circ} \mathrm{C}\right)$ solution of sarcoplasmic proteins recovered prior to ISP processing. The protein solution contained $55.7 \pm 4.6 \mathrm{mg}$ of sarcoplasmic proteins per $100 \mathrm{ml}$. The gels with $77 \mathrm{mg}$ and $144 \mathrm{mg}$ protein solution contained $77 \pm 8.3 \mathrm{mg}$ and $144 \pm 12.6 \mathrm{mg}$ sarcoplasmic proteins, respectively determined using Bradford Assay with bovine serum as the standard. Setting the $\mathrm{pH}$ of the paste to $\mathrm{pH}$ 7.0-7.2 was accomplished by adding AA or $1 \mathrm{~mol}$ equi/L $\mathrm{Ca}(\mathrm{OH})_{2}$. After chopping for an additional 3 min at 
high speed under vacuum (50kPa), the paste was transferred to a vacuum bag and vacuum packaged (Ultravac KOCH Packaging, KOCH Supplies Inc., Kansas City, MO, USA) to remove air pockets that may interfere with the texture analyses.

2.6. Preparation of the protein gels

The vacuum bag containing protein paste was placed in a stainless steel sausage stuffer and pressed into cylindrical stainless steel tubes (length $17.5 \mathrm{~cm}$, inner diameter $1.9 \mathrm{~cm}$ ) and dumbbell shaped pre-molded stainless steel torsion tubes $($ length $=17.5 \mathrm{~cm}$, end diameter $=1.9$ $\mathrm{cm}$, mid-section diameter $=1.0 \mathrm{~cm}$ ) that were lightly sprayed with cooking oil (PAM Original cooking spray, ConAgra Foods, USA) before stuffing. The tubes containing protein gels were refrigerated $\left(4^{\circ} \mathrm{C}\right)$ for $24 \mathrm{~h}$ to allow gel formation. After gel setting period, the tubes were taken out of the refrigerator and cooked in a water bath (Precision, Jouan Inc, Wincester, Virginia) at $90^{\circ} \mathrm{C}$, for $15 \mathrm{~min}$. The protein gels developed in this study are exposed to heat induced gelation. Although gel matrix forms after gel setting period, the final form of the gels are given by exposing the paste to heat. Following cooking, they were chilled on ice for $15 \mathrm{~min}$. After the gel temperature was adjusted to room temperature, they were removed from the stainless steel tubes by uncapping and letting the gel slide out of the tube. The gels were then cut into smaller pieces for further analyses. Texture and color analyses were performed on the gels samples at room temperature right after the gels were cut and adjusted to room temperature.

\subsection{Texture Profile Analysis (TPA)}

Texture profile analysis (TPA) measures rheological characteristics such as hardness, chewiness, gumminess, cohesiveness, springiness, and resilience. The analysis was performed as described elsewhere (Paker et al., 2014; Taskaya et al., 2009) and the values were computed using a software (Texture Expert Exceed version 2.64, Stable Micro Systems, 2003). The gel 
samples (length $2.54 \mathrm{~cm}$, diameter $1.9 \mathrm{~cm}$ ) were tested by being placed under a $70 \mathrm{~mm}$ TPA compression plate attachment that compressed the sample for two cycles.

\subsection{Kramer Shear Cell}

Kramer shear cell test also measures rheological attributes such as firmness and cohesiveness by mimicking mastication. A texture analyzer (Model TA-HDi, Texture Technologies Corp., Scarsdale, NY) was used to perform analysis with a Kramer cell attachment. The gel samples (length $8 \mathrm{~cm}$, diameter $1.9 \mathrm{~cm}$ ) were placed under the Kramer cell attachment consisting of five shear blades ( $3 \mathrm{~mm}$ thick and $70 \mathrm{~mm}$ wide) after being weighed. After the blades cut through the gels, shear force ( $\mathrm{N}$ peak force g/gel sample) was measured at $127 \mathrm{~mm}$ $\min ^{-1}$ crosshead speed. The shear stress is calculated as the shear force over the area of the gel.

\subsection{Torsional shear stress and strain}

A Hamman Gelometer (gel Consultant, Raleigh, NC) was used to measure torsional shear stress and shear strain at fracture. Similar to the Kramer shear cell test, these attributes help in determining gel strength and cohesiveness. The protein gels that were molded in the dumbbell shaped steel tubes were cut into $2.54 \mathrm{~cm}$ long cylinders after removal from the tubes. Top and bottom ends of the samples were glued to plastic discs, set at room temperature for $20 \mathrm{~min}$ and then placed in a Hamman torsion meter (Gel Consultants, Raleigh, NC, USA). The samples were twisted at $2.5 \mathrm{rpm}$ until they broke at fracture in the mid-section. Shear stress and strain were calculated using Torsion Vane (Gel Consultants, Raleigh, NC, USA) from torque and angular displacement data. At least 6 samples were tested for each formula and the results were presented as mean \pm standard deviation.

2.10. Color and whiteness 
A colorimeter (Minolta Camera Co. Ltd, Osaka, Japan) calibrated with a standard white plate No.21333180 (CIE L* 93.1; $a^{*} 0.3135 ; b^{*} 0.3198$ ) was used for color measurements. Colorimeter read values of $\mathrm{L}^{*}$ (lightness; scale: 0 - 100), a* (intensity in red color; scale: -60 +60 ), and b* (intensity in yellow color; scale: $-60-+60$ ) after gel samples (length $2.54 \mathrm{~cm}$, diameter $1.9 \mathrm{~cm}$ ) were placed under the sensor. For whiteness calculations, the following equation was used:

Whiteness $=100-\left[(100-\mathrm{L})^{2}+\mathrm{a}^{2}+\mathrm{b}^{2}\right]^{1 / 2}$

\subsection{Statistical Analysis}

Isoelectric solubilization and precipitation was applied 3 times for each protein gel formula tested. The gels were made from the combination of the three separate replications of protein recovery. Bradford analysis was replicated 5 times to determine the amount of sarcoplasmic protein in solution. Texture analyses (TPA, Kramer shear cell and Torsion) were replicated at least four times, and the color was measured at least six times per treatment. The data were presented as mean $( \pm \mathrm{SD})$ and analyzed by one-way analysis of variance (ANOVA). Mean values of gels made with silver carp or Alaska Pollack were separated by Tukey-Kramer's honestly significant differences test (HSD) (p< 0.05) (JMP 10, SAS Inst., Cary, N.C., USA). The significant differences between the same functional additive treatments in SC and AP were identified using a one way ANOVA test $(\mathrm{p}<0.05)$.

3. Results and Discussion

\subsection{Texture}

The purpose of using a solution of sarcoplasmic proteins in the current study was to investigate the feasibility of adding some portion of fish processing water back to the protein gel and to determine its effect on gel texture and color. Sarcoplasmic protein, a water-soluble protein found up to $30 \mathrm{~g} / 100 \mathrm{~g}$ of fish muscle tissue, majorly consists of enzymes such as endogenous 
TGase (Miyaguchi et al., 2000). TGase is an enzyme that enhances gel network formation of myofibrillar protein. Moreover, it triggers acyl transfer reaction which enables the formation of $\varepsilon$ - $(\gamma$-glutamyl)lysine linkages between molecules that are not susceptible to proteolytic activity (Yongsawatdigul \& Piyadhammaviboon, 2007). Sarcoplasmic protein isolated from common carp also showed proteolysis inhibitory activity and incorporation of $1.8 \mathrm{~g}$ sarcoplasmic protein $/ \mathrm{kg}$ paste into Threadfin bream surimi gels increased gel breaking force and resistance to deformation by inhibiting proteolysis (Siriangkanakun \& Yongsawatdigul, 2012).

Texture profile analysis (TPA) results presented in Figure 1 show that ISP-recovered silver carp (SC) protein and Alaska Pollack (AP) gels containing 5g TGase were harder, gummier, chewier, more cohesive and resilient $(\mathrm{p}<0.05)$ then all gels with added sarcoplasmic proteins. For the most part, there were no differences in springiness $(\mathrm{p}>0.05)$. There were no differences between Kramer shear stress in the SC samples ( $>0.05)$ regardless of concentration of sarcoplasmic proteins; however, similar to TPA findings, Kramer shear stress in AP samples and Kramer Shear force for both SC protein and AP was greatest $(\mathrm{p}<0.05)$ when no sarcoplasmic proteins were added to the gels (Figure 2). Torsional stress and strain results were consistent with Kramer results (Figure 2). There were no significant differences $(\mathrm{p}>0.05)$ in torsional shear stress and few differences in torsional shear strain in SC gels; however, AP gels had significantly greater $(\mathrm{p}<0.05)$ torsional shear stress and strain when no sarcoplasmic proteins were added.

Sarcoplasmic proteins have low water holding capacity and therefore, do not allow for a well-developed gel matrix formation that entraps water and the rest of the gel constituents (Sikorski, 1994). In addition, they do not form a gel matrix (Haard et al., 1994) which may explain why a very small quantity $(77 \mathrm{mg})$ of sarcoplasmic proteins in addition to $5 \mathrm{~g}$ TGase yielded similar textural impacts as adding 144mg sarcoplasmic proteins and no TGase. The 
sarcoplasmic proteins may have disrupted the gel network formation of the myofibrillar protein and interfered with TGase activity. In contrast, increasing the amount of sarcoplasmic proteins, i.e., $35 \mathrm{~g}$ from common carp and $1-5 \mathrm{~g}$ from rockfish, was reported to harden gels as indicated by textural analysis (Jafarpour \& Gorczyca, 2009; Kim et al., 2005). However, the sarcoplasmic proteins in these studies was concentrated by lyophilization, which may have induced conformational changes to native protein structure and decreased functional properties of sarcoplasmic proteins. It would be interesting to see if adding higher amounts $(>1 \mathrm{~g})$ of sarcoplasmic proteins that has not undergone any denaturation inducing process, like in this current study, would have a similar gel strengthening effect on myofibrillar protein gels.

Sodium hydroxide $(\mathrm{NaOH})$ is typically used as the processing base to increase $\mathrm{pH}$ during ISP-processing. In this present study, calcium hydroxide $\left(\mathrm{Ca}(\mathrm{OH})_{2}\right)$ was used as the processing base and this may have also played a role in the results. In a previous study from our lab, protein gels (final moisture $80 \mathrm{~g} / 100 \mathrm{~g}$ ) were made from ISP-recovered silver carp protein (using AA as the processing acid and $\mathrm{NaOH}$ as the processing base) and functional additives (including $5 \mathrm{~g}$ TGase)(Paker et al., 2014). When the current TPA data was compared to the previous data, there were no significant differences ( $p>0.05$ ) between the hardness of SC gels made with $144 \mathrm{mg}$ sarcoplasmic proteins (with no added TGase) and the standard SC gels ( $\mathrm{NaOH}, 5 \mathrm{~g}$ TGase, no added SP) from the previous study (Paker et al., 2014). Moreover, the gels made in this present study were more cohesive and resilient $(\mathrm{p}<0.05)$ than the gels prepared in the previous study (NaOH, TGase no added SP) (Paker et al., 2014). Hardness of protein gels will decrease with increasing moisture content (Lin et al., 2000); however, in this present study the final moisture was $820 \mathrm{~g} / \mathrm{kg}$ compared to $800 \mathrm{~g} / \mathrm{kg}$ in the previous study and there were no differences in gel hardness. It is likely that $\mathrm{Ca}(\mathrm{OH})_{2}$ played a role in increasing hardness of the protein gels due to 
the increased amount of calcium $(\mathrm{Ca})$ in the recovered protein fraction by withholding more water (Barbut, 1995). Therefore, replacing $\mathrm{NaOH}$ with $\mathrm{Ca}(\mathrm{OH})_{2}$ in the current study may have contributed to the harder, more resilient and more cohesive gels due to calcium fortification of the recovered protein. Further investigations that directly compare the effects of different bases on the final product are necessary.

Comparison of texture results between fish sources when the same treatment was applied showed that SC gels with added sarcoplasmic proteins (no TGase) were harder, gummier and chewier and had more torsional shear stress $(\mathrm{p}<0.05)$ compared to AP gels (no TGase) with added sarcoplasmic proteins. Addition of sarcoplasmic proteins without TGase interfered with the gel matrix formation for Alaska Pollock gels, whereas TGase addition resulted in a more $(\mathrm{p}<0.05)$ cohesive, gummier, chewier AP gel with higher $(\mathrm{p}<0.05)$ shear stress and strain compared to the gels with TGase and added sarcoplasmic proteins. Sarcoplasmic proteins and surimi wash water contain endogenous TGase which is a calcium dependent enzyme (Ramirez et al., 2007). When $\mathrm{Ca}(\mathrm{OH})_{2}$ is used as the processing base during ISP, the recovered protein has an increased calcium content (Paker et al., 2014). This calcium entrapped in the protein fraction likely interacted with the endogenous TGase in the sarcoplasmic proteins which contributed to the changes in textural properties in the silver carp protein gels. On the other hand, adding exogenous microbial TGase, which is not calcium dependent, was likely beneficial for developing protein gels from fish sources that are not calcium enhanced like Alaska Pollock surimi. Sarcoplasmic proteins recovered from the process water of surimi or seafood products may have potential as an additive in calcium fortified protein gels; however, the impact on textural properties of the final product needs to be determined.

\subsection{Color}


Color is an important attribute for consumer acceptance of a food product. ISP is an effective method of removing blood, connective tissue and certain color pigments with the use of $\mathrm{pH}$ shifts which is especially necessary when using fish with dark skin and meat such as silver carp (Taskaya et al., 2009). Still, researchers have shown that using titanium dioxide was an effective additive for a whiter and more acceptable food ingredient since some yellow pigments are retained in the protein fraction during ISP (Taskaya et al., 2010).

Lightness of the gels (Table 2) indicated by $\mathrm{L}^{*}$ were all similar to or higher than the lightness of ISP-recovered silver carp protein gels made with protein solubilized using $\mathrm{NaOH}$ and $\mathrm{HCl}$ as well as that of Alaska Pollack surimi with added titanium dioxide (Taskaya et al., 2010). Lightness of the SC gels were statistically higher $(\mathrm{p}<0.05)$ when sarcoplasmic proteins and TGase were added.This may be due to the proteolytic activity inhibition effect of sarcoplasmic proteins lowering gel darkening and the increased protein binding caused by exogenous TGase addition working synergistically to form a homogenous inner gel network (Siriangkanakun \& Yongsawatdigul, 2012).

Whiteness was the highest $(\mathrm{p}<0.05)$ when sarcoplasmic proteins and TGase were added to the recovered SC protein and AP gels (Figure 3). Moreover, when sarcoplasmic proteins and TGase were added, the whiteness of the SC protein gel was higher than gels made with recovered SC protein using $\mathrm{NaOH}$ and added titanium dioxide in a previous study (Paker et al., 2014). The whiteness of all other treatments were comparable to or higher than gels made with isoelectrically recovered $\mathrm{SC}$ protein either using $\mathrm{NaOH}$ as the processing base and with the addition of titanium dioxide (Paker et al., 2014; Taskaya et al., 2010). Using $\mathrm{Ca}(\mathrm{OH})_{2}$ as the processing base increased the whiteness of silver carp gels and may eliminate the need for 
adding titanium dioxide as a whitening agent. AP is a whiter fish that may not need a whitening agent for an acceptable final product.

\section{Conclusion}

Sarcoplasmic proteins are highly soluble and often discarded with fish processing waste water. When sarcoplasmic proteins were added to protein gels, gels were softer and less cohesive, gummy, chewy and resilient. Additionally, comparison of different protein sources, recovered silver protein and Alaska Pollack surimi, showed that different additives have different effects on gels based on the composition of the protein used. Addition of sarcoplasmic proteins reduced the gel matrix formation in AP gels; however, SC gels were not as affected by the addition of sarcoplasmic proteins as AP gels. Transglutaminases in mammal and fish tissues require $\mathrm{Ca}$ for expression of enzymatic activity. It is likely that endogenous TGase in the sarcoplasmic proteins (from fish) was more active in the silver carp gels because of the increased Ca content resulting in textural differences. Future studies comparing effects of sarcoplasmic proteins and endogenous TGase on protein gels with different calcium content would be of interest.

Acknowledgement

This work was funded by the HATCH Program Project \# (WVA 00622) and the USDA Cooperative State Research Education and Extension Service (2010- 34386- 21745). 


\section{References}

Barbut, S. (1995). Effects of calcium level on the structure of pre-heated whey protein isolate gels. LWT- Food Science and Technology, 28, 598-603.

Haard, N. F., Simpson, B. K., \& Pan, B. S. (1994). Sarcoplasmic proteins and other nitrogenous compounds. In Z. E. Sikorski, B. S. Pan, \& F. Shahidi (Eds.), Seafood proteins (pp. 13-39). New York: Chapman \& Hall.

Hall, G. M., \& Ahmad, N. H. (1997). Surimi and fish mince products. In G. M. Hall (Ed), Fish Processing Technology (pp. 74-92). New York: Springer.

Han, L., Lu, Z., Hao, X., Cheng, Y., \& Li, L. (2012). Impact of calcium hydroxide on the textural properties of buckwheat noodles. Journal of Texture Studies, 43, 227-234.

Hemung, B.O., \& Chin, K.B. (2013). Effects of fish sarcoplasmic proteins on the properties of myofibrillar protein gels mediated by microbial transglutaminase. LWT-Food Science and Technology, 53, 184-190.

Jafarpour, A., \& Gorczyca, E. M. (2009). Characteristics of sarcoplasmic proteins and their interactions with surimi and kamaboko gel. Journal of Food Science, 74, N16-N22.

Jonsson, A., Sigurgisladottir, S., Hafsteinsson, H., \& Kristbergsson, K. (2001). Textural properties of raw Atlantic salmon (Salmo salar) fillets measured by different methods in comparison to expressible moisture. Aquaculture Nutrition, 7, 81-89.

Kim, Y. S., Yongsawatdigul, J., Park, J. W., \& Thawornchinsombut, S. (2005). Characteristics of sarcoplasmic proteins and their interaction with myofibrillar proteins. Journal of Food Biochemistry, 29, 517-531. 
Lin, S., Huff, H.E., \& Hsieh, F. (2000). Texture and chemical characteristics of soy protein meat analog extruded at high moisture. Journal of Food Science Food Chemistry and Toxicology, 65(2), 264-269.

Miyaguchi, Y., Nagayama, K., \& Tsutsumi, M. (2000). Thermal and functional properties of porcine sarcoplasmic proteins: a comparison with some watersoluble animal proteins. Japanese Society of Animal Science, 71(4), 416-424.

Nakagawa, T., Nagayama, F., Ozaki, H., Watabe, S., \& Hashimoto K. (1989). Effect of glycolytic enzymes on the gel-forming ability of fish muscle. Nippon Suisan Gakkaishi, 55, $1045-1050$.

Nakayama, T., \& Sato, Y. (1971). Relationships between binding quality of meat and myofibrillar proteins. Journal of Texture Studies, 2(4), 475-488.

Okada, M. (1964). Effect of washing on the gelly forming ability of fish meat. Nippon Suisan Gakkaishi, 30, 255-261.

Otto, R. A., Beamer, S., Jaczynski, J., \& Matak, K. E. (2011a). The effect of using citric or acetic acid on survival of Listeria monocytogenes during fish protein recovery by isoelectric solubilization and precipitation process. Journal of Food Science, 76, M579- M583.

Otto, R. A., Paker, I., Bane, L., Beamer, S., Jaczynski, J., \& Matak, K. E. (2011b). Survival of Listeria inoccua in rainbow trout protein recovered by isoelectric solubilization and precipitation with acetic and citric acids. Journal of Food Protection, 74, 1348-1352. 
Paker, I., Beamer, S., Jaczynski, J., \& Matak, K.E. (2014). pH shift protein recovery with organic acids on texture and color of cooked gels. Journal of the Science of Food and Agriculture, In press.

Paker, I., Beamer, S., Jaczynski, J., \& Matak, K. E. (2013a). Compositional characteristics of materials recovered from headed gutted silver carp (Hypophthalmichthys molitrix) by isoelectric solubilization and precipitation using organic acids. Journal of Food Science, 78(3), E445-451.

Paker, I., Beamer, S., Jaczynski, J., \& Matak, K. E. (2013b). The effect of organic acids on gelation characteristics of protein gels made from silver carp (Hypophthalmichthys molitrix) protein recovered by isoelectric solubilization and precipitation. LWT-Food Science and Technology; 53, 37-43.

Ramirez, J. A., Velazquez, G., Echevarria, G. L., \& Torres, J. A. (2007). Effect of adding insoluble solids from surimi wash water on the functional and mechanical properties of pacific whiting grade A surimi. Bioresource Technology, 98, 2148-2153.

Sikorski, Z. E. (1994). The myofibrillar proteins in seafoods. In Z. E. Sikorski, B. S. Pan, \& F. Shahidi (Eds.), Seafood proteins (pp.40-57). New York: Chapman \& Hall.

Siriangkanakun, S., \& Yongsawatdigul, J. (2012). Trypsin inhibitory activity and gel-enhancing effect of sarcoplasmic proteins from common carp. Journal of Food Science, 77, C1124-1130. Stone, A. P., \& Stanley, D. W. (1992). Mechanisms of fish muscle gelation. Food Research International, 25(5): 381-388.

Taskaya, L., Chen, Y. C., Beamer, S., \& Jaczynski, J. (2009). Texture and colour properties of proteins recovered from whole gutted silver carp (Hypophthalmichthys molitrix) using isoelectric solubilization/ precipitation. Journal of the Science of Food and Agriculture, 89, 349-358. 
Taskaya, L., Chen, Y. C., \& Jaczynski, J. (2010). Color improvement by titanium dioxide and its effect on gelation and texture of proteins recovered from whole fish using isoelectric solubilization/precipitation. LWT - Food Science and Technology, 43, 401-408.

Worratao, A., \& Yongsawatdigul, J. (2005). Purification and characterization of transglutaminase from tropical tilapia (Oreochromis niloticus). Food Chemistry, 93(4), 651-658. Yasueda, H., Kumazawa, Y., \& Motoki, M. (1994). Purification and characterization of a tissuetype transglutaminase from red sea bream (Pagrus major). Bioscience Biotechnology and Biochemistry, 58, 2041-2045.

Yongsawatdigul, J, \& Piyadhammaviboon, P. (2007). Gel-enhancing effect and protein crosslinking ability of tilapia sarcoplasmic proteins. Journal of the Science of Food and Agriculture, 87(15), 2810-2816.

Yongsawatdigul, J., Worratao, A., \& Park, J. W. (2002). Effect of endogenous transglutaminase on threadfin bream surimi gelation. Journal of Food Science, 67(9), 3258-3263.

Zhu, Y., Rinzema, A., Tramper, J., \& Bol, J. (1995). Microbial transglutaminase- a review of its production and application in food processing. Applied Microbiology and Biotechnology, 44, $277-282$. 
Table 1. Description and amount of protein gel additives for different treatments. The amount of functional additives were kept at $23 \mathrm{~g}$ for a $\mathrm{kg}$ protein paste for each treatment.

\begin{tabular}{lcccccc}
\hline \multicolumn{1}{c}{ Treatment } & Protein & $\begin{array}{c}\text { Isoelectrically } \\
\text { Recovered }\end{array}$ & SP (mg) & TGase (g) & Starch (g) & Polyphosphates (g) \\
\hline SP & SC & Yes & 144 & 0 & 20 & 3 \\
SP+TGase & SC & Yes & 77 & 5 & 15 & 3 \\
TGase & SC & Yes & 0 & 5 & 15 & 3 \\
SP & AP & No & 144 & 0 & 20 & 3 \\
SP+TGase & AP & No & 77 & 5 & 15 & 3 \\
TGase & AP & No & 0 & 5 & 15 & 3 \\
\hline
\end{tabular}

SC: Silver Carp, AP: Alaska Pollock 
Table 2. Color properties of protein gels made from recovered Silver carp (SC) protein and Alaska Pollock (AP). Data are given as mean \pm standard error of mean.

\begin{tabular}{|c|c|c|c|c|}
\hline Treatment & Protein & $\mathbf{L}^{*}$ & $\mathbf{a}^{*}$ & $\mathbf{b}^{*}$ \\
\hline 144mg SP & $\mathrm{SC}$ & $76.02 \pm 2.57 \mathrm{c}$ & $-1.09 \pm 0.36 c$ & $8.77 \pm 2.75 \mathrm{a}$ \\
\hline 77mg SP+ 5g TGase & $\mathrm{SC}$ & $106.95 \pm 3.82$ a & $0.40 \pm 0.15 a$ & $2.96 \pm 1.13 b$ \\
\hline 5g TGase & $\mathrm{SC}$ & $80.63 \pm 2.13 b$ & $-0.36 \pm 0.15 b$ & $8.30 \pm 1.35 \mathrm{a}$ \\
\hline 144mg SP & AP & $80.32 \pm 2.43 b$ & $-2.24 \pm 0.27 \mathrm{a}$ & $5.10 \pm 1.67 \mathrm{a}$ \\
\hline 77mg SP+ 5g TGase & AP & $82.12 \pm 1.94 \mathrm{a}$ & $-2.66 \pm 0.25 b$ & $4.34 \pm 2.17 \mathrm{a}$ \\
\hline 5g TGase & AP & $77.32 \pm 1.02 \mathrm{c}$ & $-3.66 \pm 0.18 c$ & $-1.98 \pm 1.21 b$ \\
\hline
\end{tabular}

$\overline{\mathrm{a}, \mathrm{b}, \mathrm{c}}$ Mean values in a column within protein groups with different letters are significantly different (Tukey's least significant difference test, $\mathrm{p}<0.05)$.

Bold values indicate significant differences between the same functional additive treatments in SC and AP (one way ANOVA test, $\mathrm{p}<0.05)$. 


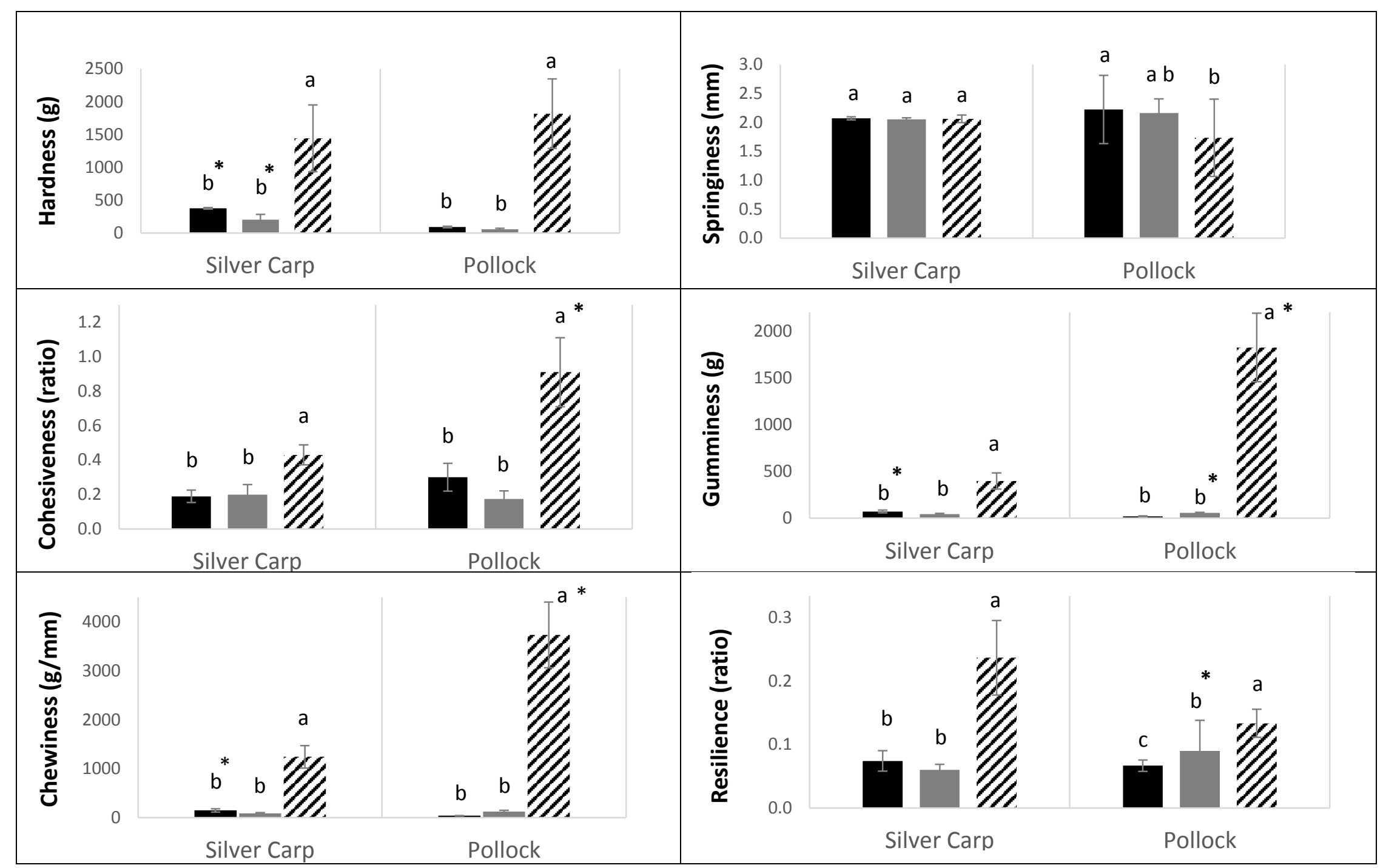

Figure 1. Hardness, Springiness, Cohesiveness, Gumminess, Chewiness and Resilience (texture profile analysis) of gels. Data are given as mean \pm standard deviation. Black solid fill indicates $144 \mathrm{mg} \mathrm{SP}$, gray solid fill shows $77 \mathrm{mg} \mathrm{SP}$ and $5 \mathrm{~g}$ TGase, and striped fill presents data for $5 \mathrm{~g}$ TGase containing gels. ${ }^{\text {ab, }, \mathrm{c} \text {, }}$ Mean values with different letters in each fish group are significantly different (Tukey's honestly significant differences test, $p<0.05$ ). Significant differences between the same functional additive treatments in silver carp and Alaska Pollock (one way ANOVA test, $\mathrm{p}<0.05$ ) are indicated with an *. 


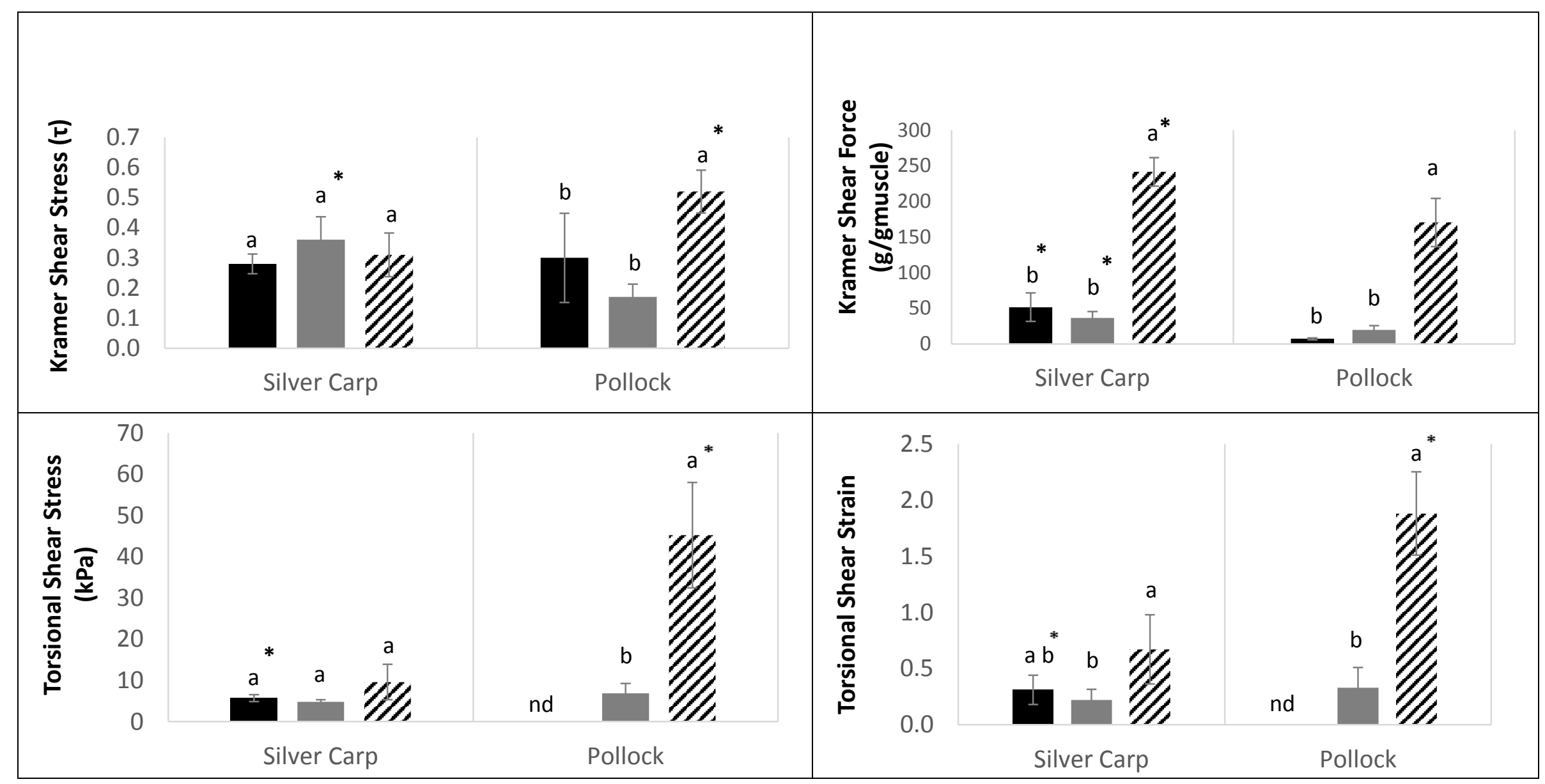

Figure 2. Kramer Shear Force, Kramer Shear Stress $(\tau)$, Torsional Stress $(\mathrm{kPa})$ and Torsional Strain of recovered silver carp protein and Alaska Pollock surimi gels. Data are given as mean \pm standard deviation. Black solid fill indicates $144 \mathrm{mg}$ SP, gray solid fill shows $77 \mathrm{mg}$ SP and $5 \mathrm{~g}$ TGase, and striped fill presents data for $5 \mathrm{~g}$ TGase containing gels. a,b,c Mean values with different letters are significantly different (Tukey's honestly significant differences test, $\mathrm{p}<0.05$ ) from the other mean values in the corresponding fish species group. Significant differences between the same functional additive treatments in silver carp and Alaska Pollock (one way ANOVA test, $\mathrm{p}<0.05$ ) are indicated with an *. nd for not detected. 


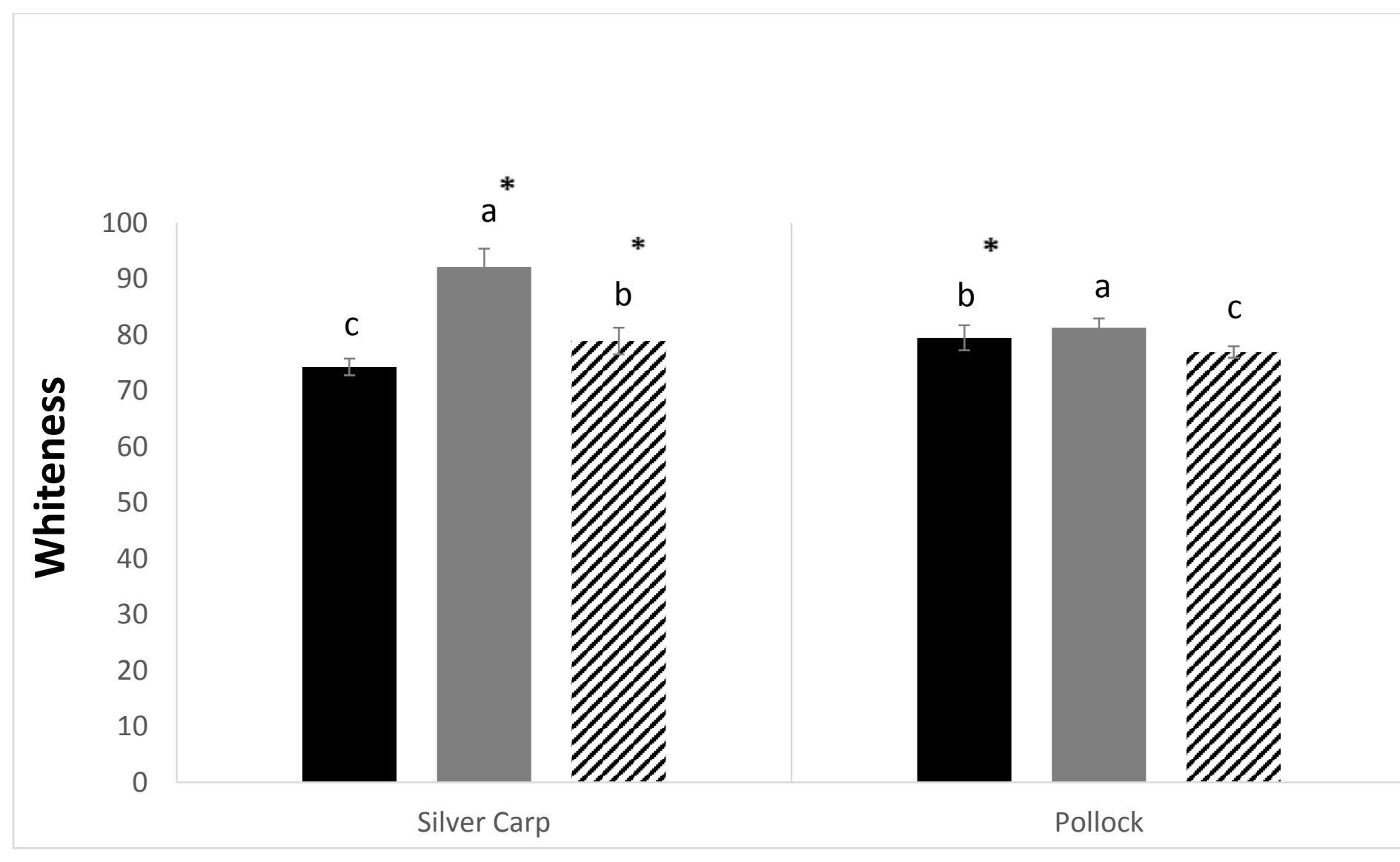

Figure 3. Whiteness of silver carp protein and Alaska Pollock surimi gels. Data are given as mean \pm standard deviation.

a,b,c Mean values with different letters in each fish group are significantly different (Tukey's honestly significant differences test, $\mathrm{p}<0.05$ ). Significant differences between the same functional additive treatments in silver carp and Alaska Pollock (one way ANOVA test, $\mathrm{p}<0.05$ ) are indicated with an *. Black solid fill indicates $144 \mathrm{mg} \mathrm{SP}$, gray solid fill shows $77 \mathrm{mg}$ SP and $5 \mathrm{~g}$ TGase, and striped fill presents data for $5 \mathrm{~g}$ TGase containing gels. 


\section{CHAPTER 5}

\section{Effects of Starch Concentration on Calcium Enhanced Black Bullhead Catfish Protein Gels}

Abstract

Myofibrillar protein recovered from black bullhead catfish (Ameiurus melas) was used to develop protein gels containing increasing amounts $(0,5,10,15,20 \mathrm{~g} / \mathrm{kg}$ protein paste $)$ of potato starch to determine the effects of starch on functional, textural and color properties of calcium enhanced protein gels. Energy required to unfold protein groups (myosin tail, actin, and sarcoplasmic proteins) was higher $(\mathrm{p}<0.05)$ with the addition of $5 \mathrm{~g}$ starch/kg protein paste. Textural properties such as hardness, gumminess, chewiness, firmness and resistance to deformation as indicated by torsional measurements were all increased $(p<0.05)$ by the addition of starch but for the most part it was not a function of starch concentration. Gels got darker $(\mathrm{p}<0.05)$ with the addition of $10,15,20 \mathrm{~g}$ starch $/ \mathrm{kg}$ paste. The textural properties of protein gels were generally not affected by starch concentrations between 5 and $20 \mathrm{~g} / \mathrm{kg}$ protein paste. 


\section{Introduction}

Myofibrillar protein consists of myosin and actin and form thermally induced protein gels by establishing a three dimensional network between protein paste constituents such as fat, protein, and water ${ }^{1,2}$. The structural and textural properties of the final gel depend on the functionality of the protein groups as well as the composition of the gel formula such as the salt amount, myosin to actin ratio, and other ingredients that might interfere with protein unfolding and aggregation. Functional additives such as starch, salt, polyphosphates, and transglutaminase (an exogenous enzyme) have been used in protein gels to enhance gelation by increasing the intermolecular interactions, water holding capacity, and rate of crosslinking ${ }^{1,2}$.

Starch granules absorb water and swell during gel formation ${ }^{3}$. Upon heating, they interact with protein and gelatinize, thus increasing gel strength ${ }^{4}$. Amylose to amylopectin ratio influence the gelation properties of different starches. Potato starch, which is high in amylopectin, will increase firmness and cohesiveness among gels made with commercially available starches such as wheat starch ${ }^{5}$. Gel strengthening properties of starch may be especially beneficial for protein gels that are made from chemically processed protein. For example, it was previously shown that myofibrillar fish protein recovered using lactic acid yielded softer and less cohesive gels compared to gels made with protein processed with hydrochloric acid during $\mathrm{pH}$ shift recovery process ${ }^{6}$.

In an effort to improve textural properties of MP gels such as hardness, cohesiveness, and resistance to deformation, strategies such as calcium and sarcoplasmic protein addition were applied; however, gel strength still remained lower than gels made with myofibrillar protein recovered using sodium hydroxide and hydrochloric acid during $\mathrm{pH}$ shift processing ${ }^{6}$. Moreover, it was important to determine the impact of modifying starch content in gels to verify the effects 
of other additives such as sarcoplasmic protein in the previously conducted studies ${ }^{6,7}$. Therefore, the aim of this study was to assess the functional, texture and color changes in myofibrillar protein gels containing increasing amounts of potato starch $(0,5,10,15,20 \mathrm{~g} / \mathrm{kg}$ protein paste).

\section{Materials and Methods}

\subsection{Ground catfish preparation}

All equipment used to handle fish were sanitized prior to fish arrival. Freshly caught (Dog Wood Lake, Morgantown WV) black bullhead catfish (Ameiurus melas) were transported to the meats processing laboratory at West Virginia University in containers with ice and carbon monoxide within $1 \mathrm{~h}$ of being caught. Fish were rinsed under running tap water, gutted, and coarsely ground twice using a meat processor (Hobart Model 4146, Troy, OH, USA) with a coarse grinding plate attachment. The coarse fish paste was then transferred to lidded stainless steel trays for storage at $-20^{\circ} \mathrm{C}$ for $12 \mathrm{~h}$ to prevent thermal denaturation. After being processed through the meat grinder using a fine grinder plate twice, the finely ground fish were individually packaged (500 g) into freezer bags (Ziplock Freezer Bags, S.C. Johnson \& Son, Inc., Racine, WI, USA). The bags of fish were vacuum packaged (Ultravac KOCH Packaging, KOCH Supplies Inc., Kansas City, MO, USA) and stored at $-80^{\circ} \mathrm{C}$ for a maximum of 5 days until further analysis was conducted.

2.2. Myofibrillar protein separation using isoelectric solubilization and precipitation (ISP) Myofibrillar fish protein was extracted using a method called isoelectric solubilization and precipitation (ISP) that relies on $\mathrm{pH}$ shifts to solubilize and then precipitate the protein ${ }^{8}$. Thawed $\left(4^{\circ} \mathrm{C}\right.$ for $\left.24-48 \mathrm{~h}\right)$, ground catfish $(500 \mathrm{~g})$ was mixed with distilled deionized water at a 1:6 (fish: water) ratio in a glass beaker. Isoelectric solubilization and precipitation was carried out as described elsewhere ${ }^{9}$. The initial $\mathrm{pH}$ of the mixture was $\mathrm{pH} 6.6 \pm 0.2$, confirmed using a 
calibrated $\mathrm{pH} /$ ion analyzer (Oakton, Eutech Instruments; Singapore). In order to facilitate protein solubilization, $1 \mathrm{~mol} \mathrm{~L}^{-1}$ calcium hydroxide $\left(\mathrm{Ca}(\mathrm{OH})_{2}\right)$ was added to the mixture to raise to the pH to 11.0 while homogenizing using a laboratory grade, sanitized homogenizer (PowerGen 700, Fisher Scientific, Pittsburgh, PA) ${ }^{9}$. After reaching the targeted $\mathrm{pH}$ value, homogenization was continued for an additional $10 \mathrm{~min}$. The mixture was then centrifuged at $10,000 \mathrm{x} \mathrm{G}$ for $15 \mathrm{~min}$ at $4^{\circ} \mathrm{C}$ (Sorvall RC-SB Refrigerated Superspeed Centrifuge, Du Pont, Wilmington, DE, USA).

Distinct layers had formed after centrifugation, lipids having formed the top layer and the bottom pellet containing insolubles (such as skin, bones, and scales) were discarded. Solubilized protein that made up the aqueous middle layer was filtered through a cheese cloth into a glass beaker. Homogenization was continued while lactic acid was added and the $\mathrm{pH}$ was reduced to the protein isoelectric point of $\mathrm{pH}$ 5.5. The mixture was homogenized for an additional $10 \mathrm{~min}$ after reaching the target $\mathrm{pH}$ to allow ample time for precipitation. The solution was then centrifuged at $10,000 \mathrm{x} \mathrm{G}$ for $15 \mathrm{~min}$ at $4^{\circ} \mathrm{C}$ and the protein having formed a pellet at the bottom of the centrifuge tubes were collected into a freezer cups. The supernatant was discarded. The recovered protein was used for paste development immediately after being collected.

\subsection{Protein paste development}

Immediately following protein recovery, the collected protein $(800 \mathrm{~g})$ was used to develop protein paste. A universal food processor (model UMC5, Stephan Machinery Corp., Columbus, $\mathrm{OH}$ ) was used to chop protein at low speed for $1 \mathrm{~min}$. Salt ( $20 \mathrm{~g} / \mathrm{kg}$ paste) was added and the mixture was chopped for $1 \mathrm{~min}$. The initial moisture of the recovered protein $(85 \mathrm{~g} / 100 \mathrm{~g})$ confirmed by a moisture analyzer (Ohaus, Model MB45, Switzerland) was adjusted to 80g/100g by adding chilled water $\left(4^{\circ} \mathrm{C}\right)$. Transglutaminase $(5 \mathrm{~g} / \mathrm{kg}$ paste $),(3 \mathrm{~g} / \mathrm{kg}$ paste $)$ polyphosphates (Kena FP-28, Innophos, Cranbury, NJ, USA) and (0, 5, 10, 15, or $20 \mathrm{~g} / \mathrm{kg}$ paste) potato starch 
(Penbind 1000 modified potato starch, Penford Food Ingredients Corp., Centennial, CO, USA) was added depending on the tested formula. After final $\mathrm{pH}$ of the mixture was adjusted to $\mathrm{pH}$ 7.0- 7.2 (Oakton, Eutech Instruments; Singapore) by adding lactic acid, the mixture was chopped for 3 min at high speed under vacuum $(50 \mathrm{kPa})$. Thermal denaturation was prevented by adjusting the temperature of the universal food processor at $1-4^{\circ} \mathrm{C}$ throughout the process. The protein paste was then transferred to vacuum bags and the air that might have interfered with the texture and color analysis results was removed (Ultravac KOCH Packaging, KOCH Supplies Inc., Kansas City, MO, USA). Protein paste (10 g) was separated for differential scanning calorimetry analysis immediately after paste development. Stainless steel tubes (length $=17.5 \mathrm{~cm}$, inner diameter $=1.9 \mathrm{~cm}$ ) and dumbbell shaped stainless steel torsion tubes (length $=17.5 \mathrm{~cm}$, end diameter $=1.9 \mathrm{~cm}$, midsection diameter $=1.0 \mathrm{~cm}$ ) were lightly sprayed with canola oil to avoid sticking of gels upon cooking. Protein paste was pressed into the tubes using a gel presser. The tubes containing the pastes were stored in the refrigerator $\left(4^{\circ} \mathrm{C}\right)$ for $24 \mathrm{~h}$ to allow for gel formation.

\subsection{Differential Scanning Calorimetry (DSC) Analysis}

Thermal changes in protein pastes (10-15 $\mu \mathrm{g})$ were assessed using differential scanning calorimetry (DSC; DSC Infinity Series F5010, Instrument Specialists, Inc., Spring Grove, IL, USA) during which temperature was increased from $5^{\circ} \mathrm{C}$ to $90^{\circ} \mathrm{C}$ at a rate of $10^{\circ} \mathrm{C} \min ^{-1}$. Analysis was replicated for 4 times per each gel sample containing different amounts of starch and the results were computed using Infinite Software (Instrument Specialists, Inc., Spring Grove, IL, USA). Thermograms were drawn for each sample using the mean values of 4 replications. Temperature onset, temperature maximum, and enthalpy required for thermal transactions were presented as mean \pm standard deviation. 


\subsection{Protein gel development}

The steel tubes containing protein pastes that were stored $\left(4{ }^{\circ} \mathrm{C}\right)$ for $24 \mathrm{~h}$ were cooked at $90^{\circ} \mathrm{C}$ for $20 \mathrm{~min}$ in a water bath (Precision, Jouan Inc, Wincester, Virginia). The cooked gels in tubes were then chilled on ice for $15 \mathrm{~min}$, and stored approximately at room temperature $(1 \mathrm{~h})$ for adjustment. The gels were then removed from the steel tubes, cut and analyzed for expressible water content, texture and color properties.

2.6. Expressible water content

Expressible water content was determined for each formula by folding $5 \mathrm{~g}$ of sample in 2 layers of Whatman No.1 filter paper and centrifuging at 7500 x G for 15 min (Eppendorf, Microcentrifuge 5430 R with F-35-6-30 rotor, Hamburg, Germany). The final weight was recorded. Expressible water content was calculated using the formula:

Expressible water $(\%)=\frac{\text { Initial weight }- \text { Final weight }}{\text { Initial weight }} \times 100$

The test was performed in triplicates for each formula tested and the results were given as mean \pm standard deviation.

\subsection{Texture Profile Analysis (TPA)}

Texture profile analysis (TPA) determining hardness, springiness, cohesiveness, gumminess, chewiness, and resilience was performed using a texture analyzer (Model TA-HDi, Texture Technologies Corp., Scarsdale, NY, USA) using a compression plate attachment (70 $\mathrm{mm})$. Gels were cut so they were $2.54 \mathrm{~cm}$ long with a diameter of $1.9 \mathrm{~cm}$. The results were calculated using Texture Expert software (Texture Expert Exceed version 2.64, Stable Micro Systems, 2003, Hamilton, MA, USA). Each gel sample made using different amount of starch was replicated at least 6 times. Data was presented as mean \pm standard deviation. 


\subsection{Kramer Shear Cell Test}

Kramer shear cell test mimics the process of a food sample being cut with a knife and is used to measure firmness and cohesiveness of a gel sample. A texture analyzer (Model TA-HDi, Texture Technologies Corp., Scarsdale, NY) with a Kramer cell attachment was used to cut through the samples with a five blade $(3 \mathrm{~mm}$ thick and $70 \mathrm{~mm}$ wide) attachment. Peak force ( $\mathrm{g}$

peak force $\mathrm{g}^{-1}$ gel sample) was measured at $127 \mathrm{~mm} \mathrm{~min}^{-1}$ crosshead speed. Shear force and shear stress were calculated by dividing the peak force by the weight of each sample, and dividing the peak force by the area of the sample, respectively. The test was replicated at least 6 times using gel samples (length $8 \mathrm{~cm}$, diameter $1.9 \mathrm{~cm}$ ) for each formula tested. The results were provided using Texture Expert software (Texture Expert Exceed version 2.64, Stable Micro Systems, 2003, Hamilton, MA, USA). Data was presented as mean \pm standard deviation.

\subsection{Torsion Analysis}

Torsional shear stress and strain measure the gel strength and uniformity by twisting the sample until it break at the mid-section of the dumbbell shaped gels. Hamman Gelometer (Gel Consultants, Raleigh, NC, USA) was used to analyze the gel samples which were glued to plastic discs at the top and bottom. Data retrieved from at least 6 replications per tested formula was analyzed using Torsion Vane software (Gel Consultants, Raleigh, NC, USA) and presented as mean \pm standard deviation.

\subsection{Color measurement}

Color was measured using a colorimeter (Minolta Camera Co. Ltd, Osaka, Japan) calibrated with a standard white plate No.21333180 (CIE L* 93.1; a* 0.3135; b* 0.3198). After collecting the data for $\mathrm{L}^{*}$ (lightness; scale: 0 - 100), a* (intensity in red color; scale: -60 - +60), and $b^{*}$ (intensity in yellow color; scale: $-60-+60$ ), whiteness was calculated using the equation: 
Whiteness $=100-\left[(100-L)^{2}+a^{2}+b^{2}\right]^{1 / 2}$

At least twelve samples were used for each formula tested and the results were given as mean \pm standard deviation.

\subsection{Statistical Analysis}

ISP and formulation trials were randomized prior to beginning of the study using JMP software (JMP 10.2, SAS Inst., Cary, NC, USA). One-way analysis of variance (ANOVA) were used at a significance level of 0.05 and the mean values for each formula tested were statistically separated using Tukey’s Honestly Significant Differences test. Data was presented as mean \pm standard deviation. Different letters $\left({ }^{\mathrm{a}, \mathrm{b}, \mathrm{c}}\right)$ were assigned to significantly different values of tested gels containing different amounts of starch. Further statistical analysis comparing the gel samples with starch $(5,10,15,20 \mathrm{~g} / \mathrm{kg}$ protein paste) were compared, significant differences $(\mathrm{p}<0.05)$ are presented with ${ }^{\mathrm{x}, \mathrm{y}, \mathrm{z}}$. Regression analysis was performed for Texture Profile Analysis data.

\section{Results and Discussion}

\subsection{Differential Scanning Calorimetry (DSC)}

Thermal changes induced in protein groups in myofibrillar protein gels containing different amounts $(0,5,10,15,20 \mathrm{~g} / \mathrm{kg}$ protein paste $)$ of starch are presented in Figure 1 and Table 1. Myosin and actin are the main protein groups in myofibrillar protein and are responsible for cross-linking and entrapping gel constituents. Starch as an additive may affect actin and myosin thermo-stability and denaturation enthalpies due to its ability to absorb and hold water as well as its gelation properties on its own. Peak I, represents the denaturation and aggregation of myosin head which was similar between gels containing different amount gels. Denaturation started around $6{ }^{\circ} \mathrm{C}$ for myosin head, where the most $(\mathrm{p}<0.05)$ energy required to unfold the 
molecule was seen in gels containing 5 and $10 \mathrm{~g}$ starch/kg protein paste. Myosin tail is relatively less thermo-susceptible than the head. Denaturation began around $26-33^{\circ} \mathrm{C}$ and enthalpy was increased $(\mathrm{p}<0.05)$ with the addition of $5 \mathrm{~g}$ starch $/ \mathrm{kg}$ protein paste. Similarly, actin and sarcoplasmic protein unfolding temperatures both onset and maximum temperature required for denaturation shown under Peak III and IV respectively was similar between gel formulae tested; however, the energy required for denaturation was much higher $(\mathrm{p}<0.05)$ for gels containing $5 \mathrm{~g}$ starch/kg protein paste.

The binding effects of starch are highly dependent on the composition of the gel constituents as well as the type of starch incorporated into the protein paste. For example, amylose and amylopectin being the major components of starch, have different effects on protein gelation. Amylopectin is the main contributor to cohesive gel network formation in protein gels increasing gel strength and viscosity, whereas amylose does not show a synergistic effect in combination with protein ${ }^{10}$. Modified potato starch used in this study has $76 \%$ amylopectin, which is higher than other starch sources. In correlation with that, granule size being an important indicator of potential for swelling is higher in potato starch while the range of particle sizes are wider compared to corn and lentil starch ${ }^{10}$. This may be the reason why a very low amount of starch, such as $5 \mathrm{~g} / \mathrm{kg}$ paste was able to affect protein unfolding and aggregation curves. Therefore, the high enthalpies (myosin tail, actin, and sarcoplasmic protein) shown in this study when a very low amount of starch $(5 \mathrm{~g} / \mathrm{kg}$ paste) was added to protein paste was possibly due to the high swelling and water absorption properties of starch granules increasing thermal stability of protein fractions without dominating or competing with protein groups for water absorption. 
Starch granules are more thermo-stable and begin gelling after the protein groups ${ }^{11}$. Both protein and starch compete for the water in the gel, and since protein starts cross-linking earlier, some portion of starch gelation is prevented by either lack of water or due to being entrapped by protein network ${ }^{12}$. Therefore, the lower thermal stability displayed by the enthalpies (myosin tail, actin, sarcoplasmic proteins) of gels containing higher amounts of starch $(10,15,20 \mathrm{~g} / \mathrm{kg}$ paste) may be due to the increased amylose and amylopectin in the paste not being able to gelatinize. Overall, the maximum amount of starch to be included in protein gels for avoiding increased thermal susceptibility depends greatly on the type and concentration of protein, starch and the other additives in the paste as well as the ionic strength, heating rate and the $\mathrm{pH}$ of the environment.

\subsection{Expressible water content}

Expressible water content is an important measure that shows how well the gel had formed around water molecules, entrapping liquid constituents. Expressible water content decreased as starch amount increased $(\mathrm{p}<0.05)$ due to the swelling of starch granules as expected (Figure 2). It is interesting to note that expressible water content was significantly lower $(\mathrm{p}<0.05)$ in gels with no starch or $10 \mathrm{~g}$ starch/kg protein paste. This was also observed in a preliminary study using calcium enhanced protein to develop protein gels with $10 \mathrm{~g}$ starch/kg paste, $3 \mathrm{~g}$ polyphosphates/kg paste, and $10 \mathrm{~g}$ sarcoplasmic protein/kg paste, where Kramer and torsional shear stress of gels were not affected from the low water holding properties but gels were softer, less cohesive, weaker, and less resistant to axial deformation (results not shown). On the other hand, a similarly designed study using sodium enhanced protein rather than calcium showed that addition of $10 \mathrm{~g}$ starch/kg protein paste formed firmer gels with higher $(\mathrm{p}<0.05)$ textural 
properties compared to similarly formulated gel made from calcium enhanced myofibrillar $\operatorname{protein}^{6,7}$.

The low expressible water content associated with less cohesive gels, observed in gels containing $10 \mathrm{~g}$ starch $/ \mathrm{kg}$ protein paste may be attributed to the calcium-starch interaction.

Calcium binds to amino acids at the carboxyl side chains ${ }^{13}$. Starch also forms hydrogen bonds at the carboxyl end of the proteins and may compete with calcium during gelation of calcium enhanced protein gels ${ }^{14}$. Moreover, increased calcium content is directly related to increased swelling of protein gels and decreased elasticity and viscosity ${ }^{14}$. Therefore, calcium competing with starch for both water and active binding sites of proteins may have been responsible for the functional and textural differences of gels having no starch or the lowest amount $(5 \mathrm{~g} / \mathrm{kg}$ protein paste) starch. It is possible that $10 \mathrm{~g} / \mathrm{kg}$ protein paste starch interfered with the calcium-protein binding; however, the amount of starch was not enough to display its gel strengthening or water withholding properties. Therefore, higher amounts of starch $(15,20 \mathrm{~g} / \mathrm{kg}$ protein paste) showed lower expressible water content.

\subsection{Texture properties}

Textural properties (hardness, springiness, gumminess, and chewiness) of the gels containing different amounts of starch are shown in Figure 3. Hardness, chewiness, and gumminess of gels containing starch was greater $(\mathrm{p}<0.05)$ than gels with no starch; however, springiness and cohesiveness did not change with the addition of starch $(\mathrm{p}>0.05)$. These properties were not changed as the amount of starch in the gels was increased. The amount of starch included in protein gels may be too small to notice more apparent differences. Increased calcium content was previously linked to higher endogenous TGase activity, and may be responsible for the "no starch gels" forming a cohesive network. It was previously reported that 
calcium increased thermo-stability of the protein gels by binding to the free carboxylic groups of aspartic and glutamic acids, thus triggering crosslinking of proteins ${ }^{15}$. The starch concentrations tested in this study are much lower than the previously conducted research using 30-80 $\mathrm{g}$ starch/kg protein paste ${ }^{12,16-19}$. Starch content in food products is usually high due to the textural improvements as well as cost ${ }^{12}$. In this study, the aim was test the effects of starch amounts generally incorporated into restructured myofibrillar protein ${ }^{6,7,20-22}$.

The gels made with $20 \mathrm{~g}$ starch/kg protein paste were less cohesive $(\mathrm{p}<0.05)$ than all other starch gels. This is consistent with previous reports where starch addition increases gel formation and water withholding up to a certain concentration, and then interferes with myofibrillar protein cross-linking properties ${ }^{12,16-19}$. Starch that is partially swollen due to inadequate amount of water in the protein paste may form large granules, leaving the portion of starch that has not absorbed water as small granules; therefore, interfering with the uniformity of the gel. Overall, there were no differences $(p>0.05)$ between starch containing gels in hardness, springiness, gumminess, and chewiness. A similar study investigating the effects of lentil starch at increasing amounts in gels concluded that starch amount did not affect $(\mathrm{p}>0.05)$ gel properties such as strength and gumminess at lower starch concentrations $(100-150 \mathrm{~g} / \mathrm{kg}){ }^{10}$. The starch amounts used in this study are much lower than the ones incorporated into gels in the previously mentioned study. Therefore, higher amounts of starch in protein gels may display more evident results in protein gel texture.

Kramer shear force and stress, and torsional shear stress and strain of gels is another indicator of gel firmness and resistance to deformation both when the force is applied at the same plane of the product as well as at axial fracture. Linear regression indicated that torsional shear stress and strain would increase with increasing concentrations of $\operatorname{starch}\left(\mathrm{R}^{2}=0.78\right.$ and 0.78 , 
respectively) (Figure 4). When only the gels containing starch were compared, the only statistical difference was between gels containing $10 \mathrm{~g}$ starch/kg protein paste and $20 \mathrm{~g}$ starch/protein paste. These results are consistent with the expressible water data and shows that starch increases swelling of muscle fibers and water with holding capacity. On the other hand, calcium enhanced protein is likely to produce more cohesive gels due to increased cross-linking interaction of myosin and actin. The effects of mineral and starch concentrations on final gel properties may depend on the amino acid composition of the myofibrillar protein, amylose to amylopectin ration of the tested potato starch, and the gel development and cooking strategy applied ${ }^{10}$.

\subsection{Color}

Color and whiteness properties of the protein gels containing increasing concentrations of starch are presented in Table 2 and Figure 5, respectively. Similar to the previous reports, the naturally lighter color of the calcium enhanced protein gels was adversely affected by the addition of higher amounts of $\operatorname{starch}(10,15,20 \mathrm{~g} / \mathrm{kg} \text { protein paste })^{21,22}$. Although previous studies reported a trend towards blue and green hue as indicated by an increase in negative $a^{*}$ and $b^{*}$ results respectively; in this study a different color scheme was observed ${ }^{21}$. The visually yellow potato starch addition increased $(\mathrm{p}<0.05)$ yellowness of gels indicated by $b^{*}$ compared to the gels containing no starch. This was also shown in a previous study, where starch containing gels were more yellow which were attributed starch addition ${ }^{9}$. The increased redness $\left(a^{*}\right)$ in the starch containing samples $(\mathrm{p}<0.05)$ may be as a result of the amylose leakage contributing opaque color $^{22}$. When starch granules swell, amylose is leaked into the gel aligning and linking itself with the protein. Upon cooking, amylose is precipitated, influencing the final color of the gel while strengthening the gel structure ${ }^{21,22}$. At a certain concentration of added starch, amylose leaking is minimized; therefore, softer and darker gels are observed in gels containing higher 
levels of starch ${ }^{21,22}$. It is possible that the starch amounts used in this study as an additive in myofibrillar protein gels were too small to see differences. The amylose content may not be adequate to improve gel color, thus a decrease in whiteness was observed with the addition of potato starch from $5 \mathrm{~g}$ starch/ $\mathrm{kg}$ protein paste until $20 \mathrm{~g}$ starch $/ \mathrm{kg}$ protein paste suggesting that higher ( $<20 \mathrm{~g} / \mathrm{kg}$ paste) amounts of starch may increase whiteness of gels.

\section{Conclusions}

Overall, gels were harder, gummier, chewier, firmer and more resistant to axial deformation $(\mathrm{p}<0.05)$ when starch was added to protein gels; however, the textural properties (hardness, springiness, chewiness, and gumminess) did not change significantly ( $>>0.05)$ with the increasing starch addition. This may be due to the interactions and competition between protein, starch and calcium to bind water in the paste. Gel color got darker with the increased starch amounts $(10,15,20 \mathrm{~g} / \mathrm{kg}$ paste $)$.

\section{Acknowledgements}

This work was funded by the HATCH Program Project \# (WVA 00622). 
References

1. Sun, X.D.; Holley, R.A. Factors influencing gel formation by myofibrillar proteins in muscle foods. Compr. Rev. Food Sci. F., 2011, 10, 33-51.

2. Brewer, M. S.; Peterson, W. J.; Carr, T. C.; Mccusker, R.; Novakofski, J. Thermal gelation properties of myofibrillar protein and gelatin combinations. J. Muscle Foods 2005, 16: 126-140.

3. Lee, C. M.; Wu, M. C.; Okada, M. Ingredient and formulation technology for surimi-based products. In Surimi Technology; Lanier, T. C.; Lee, C. M., eds.: Marcel Dekker Inc., New York. 1992, pp. 173-302.

4. Hunt, A.; Getty, K. J.; Park, J. W. Development of temperature tolerant surimi gels using starch-protein interactions. J. Food Quality 2010, 33, 119-136.

5. Kim, J. M.; Lee, C. M. Effect of starch on textural properties of surimi gels. J. Food Sci. 1987, $52,722-725$.

6. Paker, I. The effect of sarcoplasmic protein powder as an additive in myofibrillar protein gels recovered by $\mathrm{pH}$-shift process using lactic acid. In Calcium enhanced protein recovery from underutilized aquatic resources and optimizing protein gelation strategies using functional ingredients, $\mathrm{PhD}$ Dissertation submitted to Animal and Nutritional Sciences Department at West Virginia University, 2015.

7. Paker, I. Sarcoplasmic protein powder as an additive in calcium enhanced catfish protein gels. In Calcium enhanced protein recovery from underutilized aquatic resources and optimizing protein gelation strategies using functional ingredients, $\mathrm{PhD}$ Dissertation submitted to Animal and Nutritional Sciences Department at West Virginia University, 2015.

8. Gehring, C.K.; Gigliotti, J. C.; Moritz, J. S.; Tou, J. C.; Jaczynski, J. Functional and nutritional characteristics of proteins and lipids recovered by isoelectric processing of fish by-products and low-value fish: A review. Food Chem. 2011, 124, 422-431.

9. Paker, I.; Beamer, S.; Jaczynski, J.; Matak, K. E. Compositional characteristics of materials recovered from headed gutted silver carp (Hypophthalmichthys molitrix) by isoelectric solubilization and precipitation using organic acids. J. Food Sci. 2013, 78, E445-E451. 
10. Joshi, M.; Aldred, P.; McKnight, S.; Panozzo, J. F.; Kasapis, S.; Adhikari, B.; Adhikari, B. Physicochemical and functional characteristics of lentil starch. Carbohyd Polym. 2013, 92, 14841496.

11. Kong, C.S.; Ogawa, H.; Iso, N. Compression properties of fish-meat gel as affected by gelatinization of added starch. J. Food Sci. 1999, 64, 283-286.

12. Hunt, A.; Getty, K. J. K.; Park, J. W. Roles of starch in surimi seafood: A review starch and surimi seafood. Food Rev. Int. 2009, 25, 299-312.

13. Hauschka, P. V.; Lian, J. B.; Gallop, P. M. Direct identification of the calcium-binding amino acid, $\gamma$-carboxyglutamate, in mineralized tissue. P. Natl. Acad. Sci. U.S.A. 1975, 72, 3925-3929.

14. Sanoja, R. R.; Ruiz, B.; Guyot, J. P.; Sanches, S. Starch-binding domain affects catalysis in two lactobacillus $\alpha$-amylases. Appl. Environ. Microb. 2005, 71, 297-302.

15. Yang, N.; Luan, J.; Ashton, J.; Gorczyca, E.; Kasapis, S. Effect of calcium chloride on the structure and in vitro hydrolysis of heat induced whey protein and wheat starch composite gels. Food Hydrocolloid. 2014, 42, 260-268.

16. Yoon, W.B.; Park, J.W.; Kim, B.Y. Linear programming in blending various components of surimi seafood. J. Food Sci. 1997, 62, 561-567.

17. Yang, H.; Park, J.W. Effects of starch properties and thermal-processing conditions on surimi starch gels. LWT- Food Sci. Technol. 1998, 31, 344-353.

18. Chen, J.S.; Lee, C.M.; Crapo, C. Linear programming and response surface methodology to optimize surimi gel texture. J. Food Sci. 1993, 58, 535-549.

19. Yoo, B.; Lee, C.M. Rheological relationships between surimi sol and gel as affected by ingredients. J. Food Sci. 1993, 58, 880-883.

20. Paker, I.; Beamer, S.; Jaczynski, J.; Matak, K. E. The effect of organic acids on gelation characteristics of protein gels made from silver carp (Hypophthalmichthys molitrix) protein recovered by isoelectric solubilization and precipitation. LWT - Food Sci. Technol. 2013, 53, 3721. Paker, I.; Beamer, S.; Jaczynski, J.; Matak, K. E. pH shift protein recovery with organic acids on texture and color of cooked gels. J Sci. Food Agr. 2015, 95, 275-280. 
22. Paker, I.; Matak, K. E. Influence of pre-cooking protein paste gelation conditions and postcooking gel storage conditions on gel texture, J Sci. Food Agr. DOI: 10.1002/jsfa.7091.

23.

20. Giunee, T. P.; Feeney, E. P.; Auty, M. A. E.; Fox, P. F. Effect of pH and calcium concentration on some textural and functional properties of mozzarella cheese. J. Dairy Sci.

2002, 85, 1655-1669.

21. Chai, P. P.; Park, J. W. physical properties of fish proteins cooked with starches or protein additives under ohmic heating. J. Food Qual. 2007, 30, 783-796.

22. Sivak, M. N.; Preiss, J. Basic science to biotechnology. In Advances in Food and Nutrition Research, Sivak, M. N.; Preiss, J, Eds.; Academic Press: New York, NY, USA. 1998, pp. 1-32. 


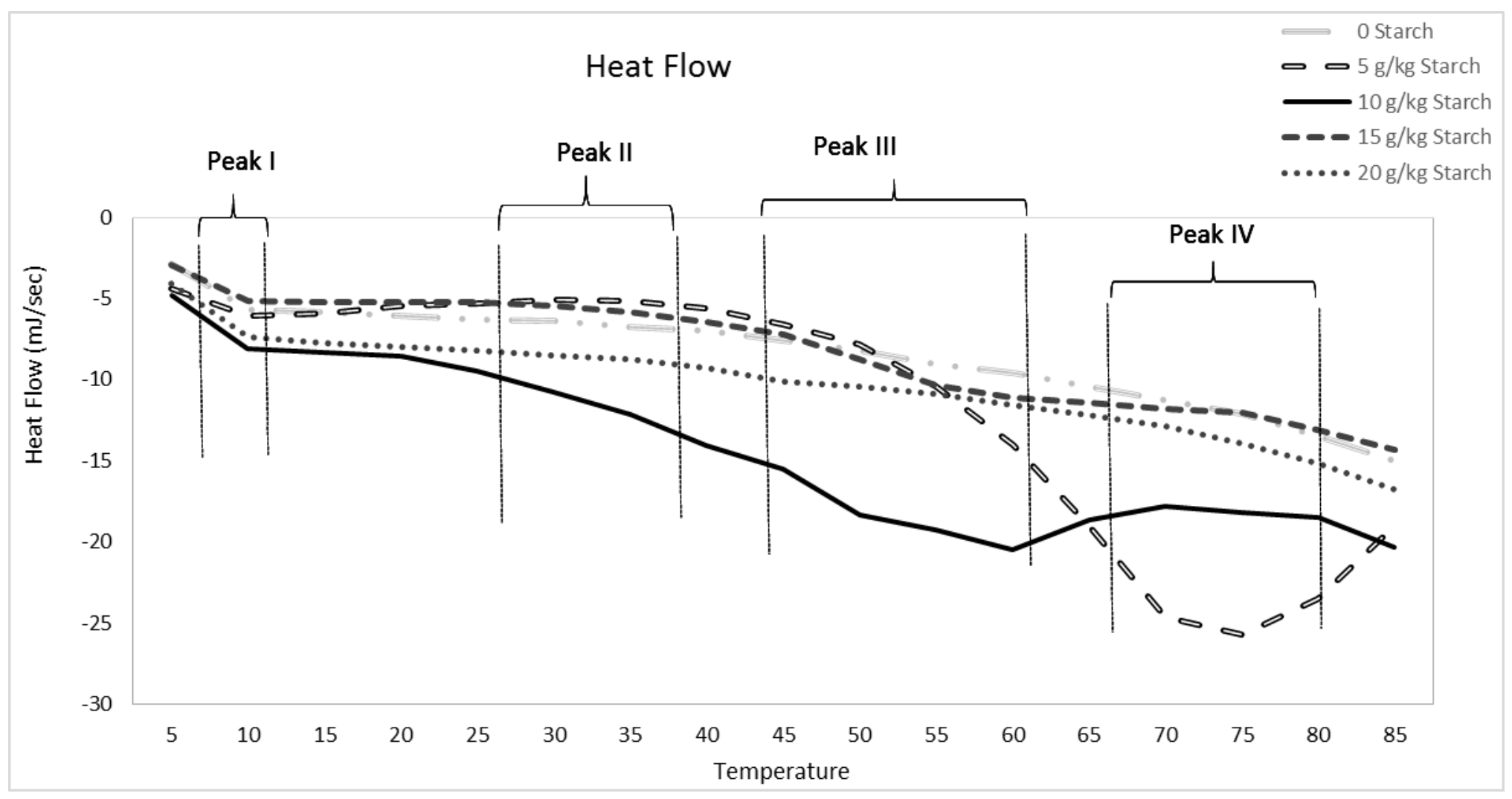

Figure 1. Differential scanning calorimetry (DSC) thermograms of black bullhead catfish protein pastes developed using different amounts of starch $(0,5,10,15,20 \mathrm{~g} / \mathrm{kg}$ protein paste). Each curve was drawn using the mean of data points collected from 4 individual replications. 


\section{Expressible Water}

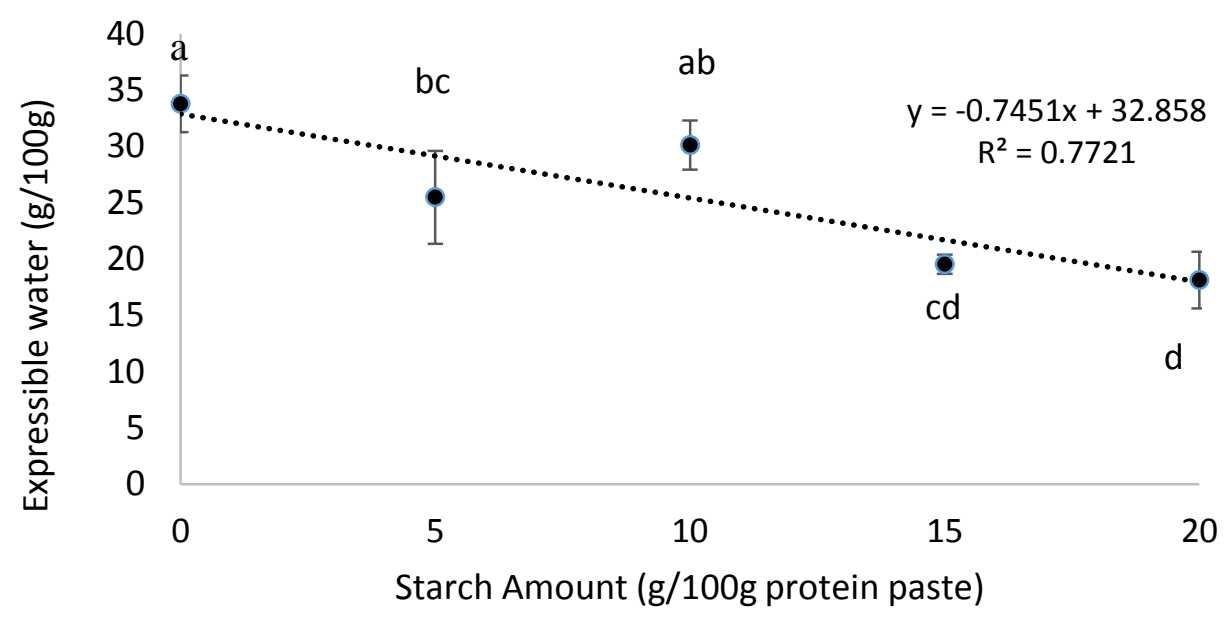

Figure 2. Expressible water $(\mathrm{g} / 100 \mathrm{~g})$ content of protein pastes containing different amounts of starch $(0,5,10,15,20 \mathrm{~g} / \mathrm{kg}$ protein paste).

${ }^{a, b, c}$ Mean values with different letters are significantly different (Tukey’s honestly significant differences test, $\mathrm{p}<0.05$ ). 


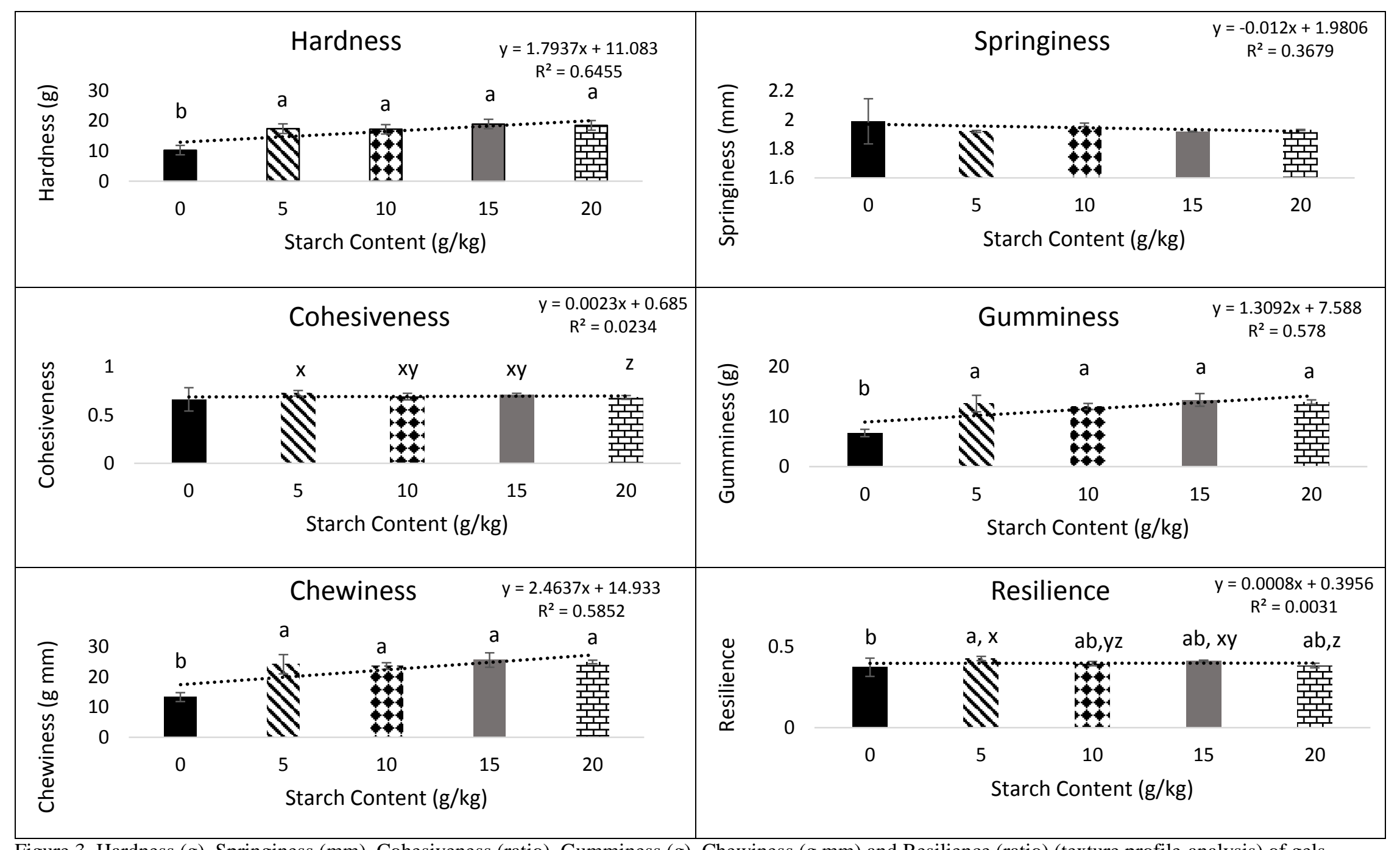

Figure 3. Hardness (g), Springiness (mm), Cohesiveness (ratio), Gumminess (g), Chewiness (g mm) and Resilience (ratio) (texture profile analysis) of gels containing different amounts of starch $\left(0,5,10,15,20 \mathrm{~g} / \mathrm{kg}\right.$ protein paste). Data are given as mean \pm standard deviation. ${ }^{\mathrm{a}, \mathrm{b}, \mathrm{c}}$ Indicate differences between all treatments and ${ }^{\mathrm{x}, \mathrm{y}, \mathrm{z}}$ indicate significant differences between only the gels containing starch $(5,10,15,20 \mathrm{~g} / \mathrm{kg}$ protein paste) (Tukey's honestly significant differences test, $\mathrm{p}<0.05)$. 


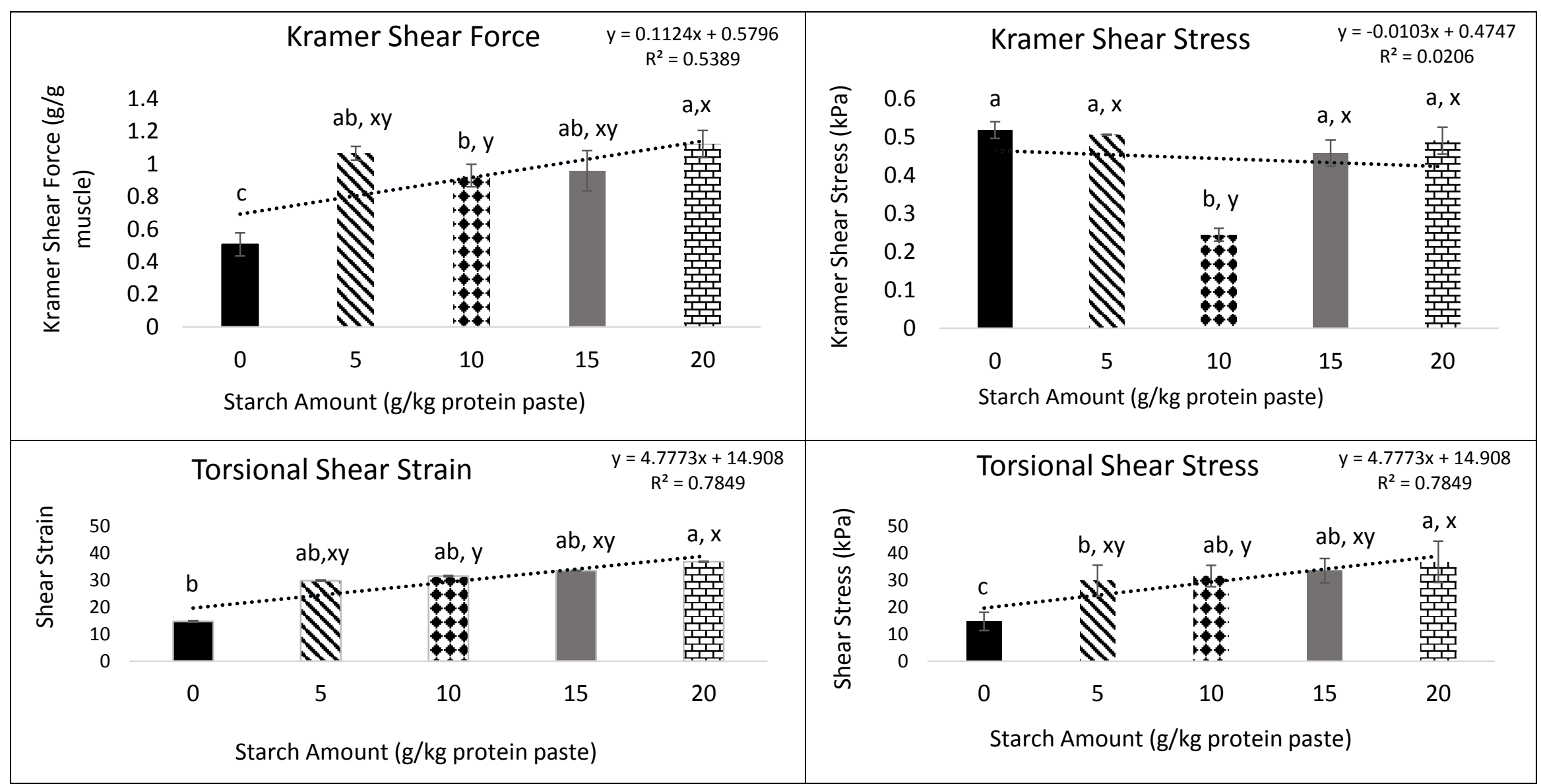

Figure 4. Kramer shear stress $(\mathrm{kPa})$, Kramer shear force $(\mathrm{g} / \mathrm{g}$ muscle), torsional shear stress $(\mathrm{kPa})$ and torsional shear strain of recovered black bullhead catfish protein gels containing different amounts of starch $(0,5,10,15,20 \mathrm{~g} / \mathrm{kg}$ protein paste). Data are given as mean \pm standard deviation. ${ }^{\mathrm{a}, \mathrm{b}, \mathrm{c}}$ Indicate differences between all treatments and ${ }^{\mathrm{x}, \mathrm{y}}$ indicate significant differences between only the gels containing starch $(5,10,15,20 \mathrm{~g} / \mathrm{kg}$ protein paste) (Tukey's honestly significant differences test, $\mathrm{p}<0.05)$. 


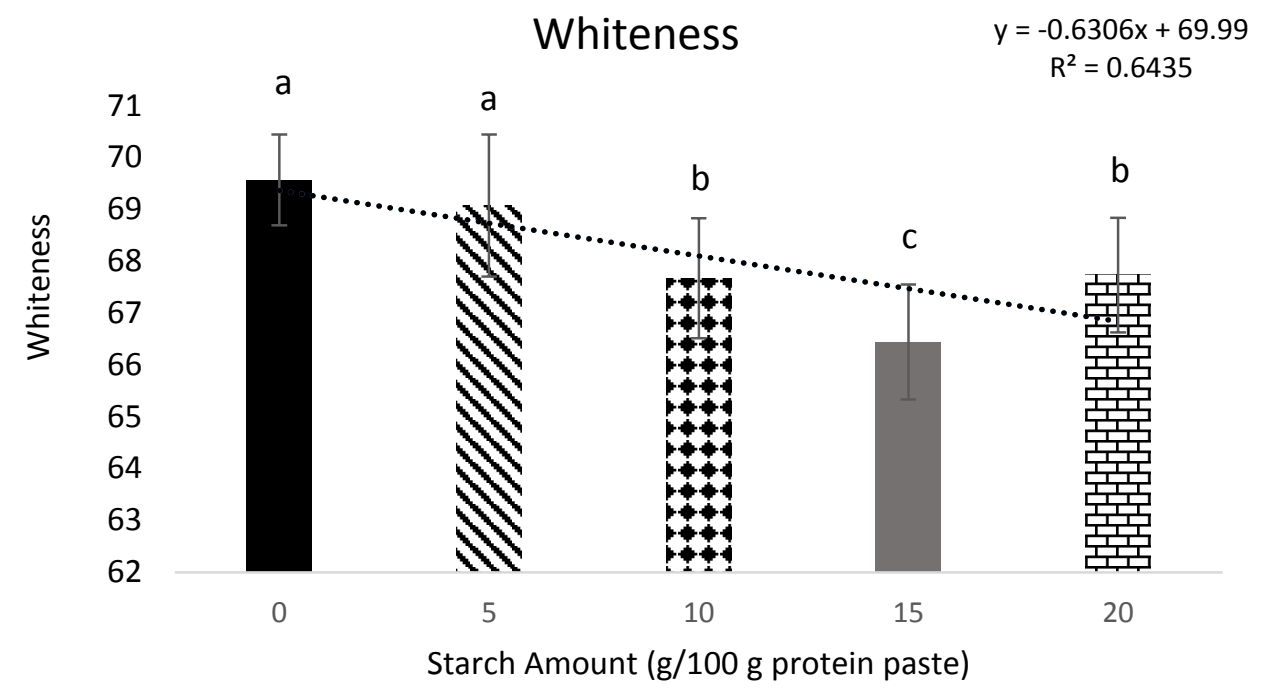

Figure 5. Whiteness of recovered black bullhead catfish protein gels containing different amounts of starch $(0,5,10,15,20 \mathrm{~g} / \mathrm{kg}$ protein paste). Data are given as mean \pm standard deviation. ${ }^{\mathrm{a}, \mathrm{b}, \mathrm{c}}$ Mean values with different letters are significantly different (Tukey's honestly significant differences test, $\mathrm{p}<0.05)$. 
Table 1. Differential scanning calorimetry (DSC) measurements (temperature onset (Tonset), maximum temperature (Tmax), and net enthalpy) of isoelectrically recovered black bullhead catfish protein pastes developed using different amounts of starch $(0,5,10,15$, $20 \mathrm{~g} / \mathrm{kg}$ protein paste). Peak I and II represent the heat flow required to unfold myosin head and tail respectively. Peak III and IV represent the heat flow required to unfold actin and sarcoplasmic protein respectively. Data are given as mean \pm standard deviation.

\begin{tabular}{cllllll}
\hline & Peak I & \multicolumn{5}{c}{ Peak II } \\
\cline { 2 - 6 } Starch $(\mathrm{g} / \mathrm{kg})$ & Tonset $\left({ }^{\circ} \mathrm{C}\right)$ & $\operatorname{Tmax}\left({ }^{\circ} \mathrm{C}\right)$ & Enthalpy $(\mathrm{J} / \mathrm{g})$ & Tonset $\left({ }^{\circ} \mathrm{C}\right)$ & $\operatorname{Tmax}\left({ }^{\circ} \mathrm{C}\right)$ & Enthalpy $(\mathrm{J} / \mathrm{g})$ \\
\hline 0 & $6.08 \pm 0.31 \mathrm{ab}$ & $11.10 \pm 0.79 \mathrm{a}$ & $1.79 \pm 0.20 \mathrm{~b}$ & $26.26 \pm 4.53$ & $32.67 \pm 4.19 \mathrm{~b}$ & $0.35 \pm 0.09 \mathrm{c}$ \\
5 & $5.50 \pm 0.26 \mathrm{~b}$ & $9.11 \pm 0.71 \mathrm{~b}$ & $2.51 \pm 0.11 \mathrm{a}$ & $33.94 \pm 5.72$ & $41.55 \pm 5.04 \mathrm{a}$ & $1.95 \pm 0.14 \mathrm{a}$ \\
10 & $6.28 \pm 0.30 \mathrm{a}$ & $10.76 \pm 0.40 \mathrm{ab}$ & $2.49 \pm 0.32 \mathrm{a}$ & $29.08 \pm 1.51$ & $35.93 \pm 2.93 \mathrm{ab}$ & $0.63 \pm 0.17 \mathrm{bc}$ \\
15 & $5.98 \pm 0.36 \mathrm{ab}$ & $10.70 \pm 0.54 \mathrm{ab}$ & $1.67 \pm 0.25 \mathrm{~b}$ & $26.96 \pm 3.36$ & $35.69 \pm 2.40 \mathrm{ab}$ & $1.02 \pm 0.29 \mathrm{~b}$ \\
20 & $6.01 \pm 0.32 \mathrm{ab}$ & $11.11 \pm 1.68 \mathrm{a}$ & $1.3 \pm 0.12 \mathrm{~b}$ & $25.67 \pm 2.80$ & $33.31 \pm 4.00 \mathrm{ab}$ & $0.51 \pm 0.16 \mathrm{C}$ \\
\hline & Peak III & & & Peak IV & & \\
\hline Starch (g/kg) & Tonset $\left({ }^{\circ} \mathrm{C}\right)$ & $\operatorname{Tmax}\left({ }^{\circ} \mathrm{C}\right)$ & Enthalpy $(\mathrm{J} / \mathrm{g})$ & Tonset $\left({ }^{\circ} \mathrm{C}\right)$ & $\operatorname{Tmax}\left({ }^{\circ} \mathrm{C}\right)$ & Enthalpy $(\mathrm{J} / \mathrm{g})$ \\
\hline 0 & $54.38 \pm 1.83 \mathrm{ab}$ & $57.43 \pm 1.26 \mathrm{bc}$ & $0.22 \pm 0.09 \mathrm{~b}$ & $71.47 \pm 2.53$ & $80.30 \pm 1.69$ & $0.27 \pm 0.05 \mathrm{C}$ \\
5 & $56.4 \pm 2.97 \mathrm{a}$ & $69.36 \pm 4.92 \mathrm{a}$ & $62.40 \pm 17.77 \mathrm{a}$ & $70.18 \pm 6.93$ & $79.41 \pm 5.41$ & $8.26 \pm 2.09 \mathrm{a}$ \\
10 & $55.02 \pm 3.37 \mathrm{ab}$ & $57.95 \pm 2.85 \mathrm{bc}$ & $1.74 \pm 0.48 \mathrm{~b}$ & $74.83 \pm 2.58$ & $79.59 \pm 3.95$ & $0.55 \pm 0.10 \mathrm{C}$ \\
20 & $51.51 \pm 2.36 \mathrm{~b}$ & $64.56 \pm 8.15 \mathrm{ab}$ & $4.09 \pm 1.09 \mathrm{~b}$ & $68.50 \pm 4.06$ & $73.53 \pm 2.57$ & $3.04 \pm 0.34 \mathrm{~b}$ \\
\hline
\end{tabular}

$\overline{\mathrm{a}, \mathrm{b}, \mathrm{c}}$ Mean values with different letters are significantly different (Tukey's honestly significant differences test, $\mathrm{p}<0.05$ ). 
Table 2. Color properties of recovered black bullhead catfish protein gels containing different starch amounts $(0,5,10,15,20 \mathrm{~g} / \mathrm{kg}$ protein paste), where $L^{*}$ indicates lightness (scale: $0-100$ ), a* measures the intensity of red color (scale: -60 to +60 ), and b* shows the intensity of yellow color (scale: -60 to +60 ). Data are given as mean \pm standard deviation.

\begin{tabular}{cccc}
\hline Starch $(\mathrm{g} / \mathrm{kg}$ paste $)$ & $\mathrm{L}^{*}$ & $\mathrm{a}^{*}$ & $\mathrm{~b}^{*}$ \\
\hline 0 & $70.88 \pm 1.00 \mathrm{a}$ & $-0.16 \pm 0.07 \mathrm{c}$ & $8.77 \pm 0.49 \mathrm{~b}$ \\
5 & $70.69 \pm 1.56 \mathrm{a}$ & $-0.46 \pm 0.16 \mathrm{~d}$ & $9.79 \pm 0.65 \mathrm{a}$ \\
10 & $69.09 \pm 1.20 \mathrm{~b}$ & $-0.19 \pm 0.08 \mathrm{c}$ & $9.43 \pm 0.29 \mathrm{a}$ \\
15 & $67.96 \pm 1.12 \mathrm{~b}$ & $0.26 \pm 0.08 \mathrm{a}$ & $9.94 \pm 0.22 \mathrm{a}$ \\
20 & $69.14 \pm 1.00 \mathrm{~b}$ & $0.09 \pm 0.02 \mathrm{~b}$ & $9.38 \pm 0.88 \mathrm{a}$ \\
\hline
\end{tabular}

a, b, c, d Mean values with different letters are significantly different (Tukey’s honestly significant differences test, $\mathrm{p}<0.05$ ). 


\section{CHAPTER 6}

\section{The Effect of Sarcoplasmic Protein Powder as an Additive in Myofibrillar Protein Gels Recovered by pH-Shift Process Using Lactic Acid}

Abstract

Myofibrillar protein (MP) was recovered from ground black bullhead catfish using a pHshift process where MP was solubilized at $\mathrm{pH} 11.0$ using sodium hydroxide $(\mathrm{NaOH})$ and precipitated at $\mathrm{pH} 5.5$ with lactic acid (LA) or hydrochloric acid ( $\mathrm{HCl})$. Sarcoplasmic protein (SP) was recovered by dilution and drying. MP was mixed with standard functional additives and sarcoplasmic protein (SP) at different concentrations and the functional, textural and color properties of protein pastes and cooked gels were tested. The effect of processing acid type (LA or $\mathrm{HCl}$ ) during MP recovery on paste and gel properties were also investigated. Although thermal unfolding of MP gels were not greatly affected by SP incorporation, gels were harder, gummier, chewier, firmer, and more cohesive $(\mathrm{p}<0.05)$ when $5 \mathrm{~g}$ TGase/kg paste was added to MP. For the most part, MP recovered using $\mathrm{HCl}$ had improved $(\mathrm{p}<0.05)$ textual properties (harder, gummier, chewier, and firmer) compared to similarly formulated MP gels developed from LA recovered MP. SP addition yielded whiter $(\mathrm{p}<0.05)$ MP gels. The influence of SP may be more evident if greater amounts (>23 g SP/kg paste) are added to MP gels. Moreover, SP may be used in reconstructed food products where softer gel structure is desired.

Keywords: sarcoplasmic protein, lactic acid, protein gel, functionality, texture, color 


\section{Introduction}

Surimi, a worldwide consumed myofibrillar protein (MP) concentrate, is obtained by extensively washing fish mince usually from white-fleshed fish such as Alaska Pollock ${ }^{1-2}$. Standard surimi is composed of 35-45g/100g protein, $40 \mathrm{~g} / 100 \mathrm{~g}$ water, 5-10 g/100g starch, 1 $\mathrm{g} / 100 \mathrm{~g}$ additives, $5 \mathrm{~g} / 100 \mathrm{~g}$ oil, $2 \mathrm{~g} / 100 \mathrm{~g}$ salt and trace amount of flavorings and colorants ${ }^{3-4}$. The repeatedly performed wash cycles facilitates removal of gelation interfering agents such as water soluble proteins and lipids, resulting in a reduction of the final protein content yet an improvement of functional and textural properties in the final product ${ }^{2,5}$. The process water contains from $0.5-2.3 \mathrm{~g} / 100 \mathrm{~g}$ up to $50 \mathrm{~g} / 100 \mathrm{~g}$ solids of which are mainly sarcoplasmic proteins (SP) ${ }^{2,6-8}$. SP are water soluble, are easily collected, and have the potential to be incorporated back into the human diet rather than being discarded ${ }^{5,9}$. One way of utilizing the SP is to add it back to MP and process it into a surimi-like gel. Although there is controversy on the effects of using SP as an additive in protein gels, recent studies highlight possible positive contributions to MP gelation such as increased gel strength and inhibition of proteases that would otherwise denature the gel ${ }^{15,16}$.

Protein isolates similar to surimi are concentrated MP often collected from underutilized species such as carp, catfish, and mackerel ${ }^{10-12}$. Recovery of protein isolates is generally achieved by using a pH shift recovery process. MP in ground fish is solubilized by adjusting the $\mathrm{pH}$ to extremely high (10.5-13) or low (2.0-3.0) values followed by protein precipitation at the isoelectric point of protein $(\mathrm{pH} 5.5)^{17}$. Since this is a chemical process, a certain degree of irreversible denaturation is inflicted upon the protein; however, the majority of the recovered protein displays similar functionality as the initial starting material or Alaska Pollock surimi ${ }^{18}$. In order to more efficiently and sustainably utilize aquatic resources, strategies to repurpose the 
SP protein that would have been discarded should be investigated. Therefore, the main objective of this study was to assess the changes in functional, textural, and color properties of MP pastes and gels as a result of increasing SP concentration. In addition, it was previously suggested that using organic acids (such as formic and lactic acid) during the $\mathrm{pH}$-shift process would induce fewer changes in protein functionality when compared to the traditionally used strong acid, hydrochloric acid $(\mathrm{HCl})^{13,14}$. Furthermore, sodium lactate which would be present in MP recovered using LA, was reportedly two times more effective than sucrose as a cyroprotectant due to stabilizing effect on actomyosin (indicator of gel formation) ${ }^{19}$. Therefore the differences in functional, textural, and color properties of pastes and gels made from MP solubilized using LA and $\mathrm{HCl}$ were compared.

2. Materials and Methods

\subsection{Preparation of starting material}

Fresh black bullhead catfish (Ameiurus melas) was supplied by Dog Wood Lake, Morgantown WV. Fish were placed in coolers filled with ice and carbon monoxide. Upon arrival at the meats processing laboratory at West Virginia University the fish were immediately headed, gutted and rinsed under running tap water. A sanitized meat grinder (Hobart Model 4146, Troy, $\mathrm{OH}, \mathrm{USA}$ ) with a coarse grinder plate was used to ground the fish into a thick paste which was stored in steel trays with plastic lids and chilled at $-20^{\circ} \mathrm{C}$ freezer overnight. The frozen thick paste was ground further using a fine grinder plate, then the fine paste was individually packaged (500g) into freezer bags (Ziplock Freezer Bags, S.C. Johnson \& Son, Inc., Racine, Wis., U.S.A.), vacuum packaged (Ultravac KOCH Packaging, KOCH Supplies Inc., Kansas City, MO, USA) and stored at $-80^{\circ} \mathrm{C}$ until analyses were performed. The experiments were completed in 10 days.

\subsection{SP Recovery}


Initial starting material, finely ground catfish $(1500 \mathrm{~g})$ was thawed at $4{ }^{\circ} \mathrm{C}$ for $24-48 \mathrm{~h}$ prior to experiments. After diluting the thawed, ground fish at a ratio of 1:3 fish: deionized/distilled water, the solution was homogenized for 15 min using a steel homogenizer (PowerGen 700, Fisher Scientific, Pittsburgh, PA). The solution was then transferred to centrifuge bottles, and spun at $10,000 \times \mathrm{G}$ for $15 \mathrm{~min}$ at $4^{\circ} \mathrm{C}$ (Sorvall RC-SB Refrigerated Superspeed Centrifuge, Du Pont, Wilmington, DE, USA). The supernatant was filtered through cheese cloth into freezer cups. Following lyophilization (VirTis Freeze Dryer, SP Scientific, Stone Ridge, NY, USA), the SP in powder form was weighed and stored at $4{ }^{\circ} \mathrm{C}$ until further analysis.

\subsection{MP Recovery}

MP was separated from ground catfish using isoelectric solubilization and precipitation (ISP) process which is a $\mathrm{pH}$-shift protein extraction method. Initial starting material (1500 $\mathrm{g})$ was diluted at a ratio of 1:6 with distilled/deionized water in a glass beaker and homogenized (PowerGen 700, Fisher Scientific, Pittsburgh, PA). MP protein solubilization occurred at pH 11.0 (pH analyzer, Oakton, Eutech Instruments; Singapore) with the addition of $10 \mathrm{~N} \mathrm{NaOH}$ and homogenization was continued for an additional $10 \mathrm{~min}$ to stabilize the solution. The solution was transferred to $1 \mathrm{~L}$ centrifuge bottles and spun at $10,000 \times \mathrm{G}$ for $15 \mathrm{~min}$ at $4^{\circ} \mathrm{C}$ (Sorvall $\mathrm{RC}$ SB Refrigerated Superspeed Centrifuge, Du Pont, Wilmington, DE, USA). Phase separation was achieved during centrifugation. The lipid fraction formed the top layer and was removed using a metal spatula. The middle section containing the aqueous protein slurry was filtered through a cheese cloth into a glass beaker. The $\mathrm{pH}$ of the solution was reduced to the protein isoelectric point of $\mathrm{pH} 5.5$ using $\mathrm{LA}$ or $\mathrm{HCl}$. The homogenization continued for another 5 min after confirming the $\mathrm{pH}$ of 5.5 to allow for more efficient protein precipitation. The solution was then 
poured into $1 \mathrm{~L}$ centrifuge bottles and centrifuged at $10,000 \times \mathrm{G}$ for $15 \mathrm{~min}$ at $4^{\circ} \mathrm{C}$. The protein fraction formed a pellet following centrifugation and the supernatant was discarded. Recovered protein was immediately used to develop protein pastes.

\subsection{Development of protein paste}

Extracted MP (800 g) was chopped in a universal food processor (model UMC5, Stephan Machinery Corp., Columbus, $\mathrm{OH})$ at low speed for $1 \mathrm{~min}$. Salt $(20 \mathrm{~g} / \mathrm{kg})$ was added and the mixture was chopped for 1 more min. Moisture of the mixture was adjusted to $800 \mathrm{~g} / \mathrm{kg}$ (Ohaus Model MB45, Nänikon, Switzerland) by adding chilled distilled/deionized water $\left(4{ }^{\circ} \mathrm{C}\right)$. Standard functional additives including potato starch $(0,10$, or $15 \mathrm{~g} / \mathrm{kg})$ (Penbind 1000 modified potato starch, Penford Food Ingredients Corp., Centennial, CO); polyphosphates ( 0 or $3 \mathrm{~g} / \mathrm{kg}$ ) (Kena FP-28, Innophos, Cranbury, NJ) and transglutaminase (TGase) (0 or 5g/kg) were added at quantities to keep the total amount of additives at $23 \mathrm{~g} / 100 \mathrm{~g}$. SP was added at 0,10 , or $23 \mathrm{~g} / \mathrm{kg}$ depending on the tested formula. The total amount of functional additives were fixed at $23 \mathrm{~g} / \mathrm{kg}$ paste which is the standard amount. The mixture was chopped for $1 \mathrm{~min}$ and the $\mathrm{pH}$ was adjusted to $\mathrm{pH} 7.0-7.2$ by adding $10 \mathrm{~N} \mathrm{NaOH}$. After confirming the $\mathrm{pH}$, the mixture was chopped for 3 min at high speed under vacuum $(50 \mathrm{kPa})$. Temperature of the mixture was maintained at $1-4{ }^{\circ} \mathrm{C}$ throughout the process. The paste was then transferred into a vacuum bag and vacuum packaged. A gel presser was used to stuff the paste into stainless steel tubes (length $=17.5 \mathrm{~cm}$, inner diameter $=1.9 \mathrm{~cm})$ and dumbbell shaped stainless steel torsion tubes $($ length $=17.5 \mathrm{~cm}$, end diameter $=1.9 \mathrm{~cm}$, midsection diameter $=1.0 \mathrm{~cm}$ ) both of which were lightly sprayed with canola oil to prevent sticking.

\subsection{Differential Scanning Calorimetry (DSC) Analysis}


Thermal changes (temperature onset, maximum temperature, and enthalpy) in the protein paste when subjected to heat was measured using DSC (DSC Infinity Series F5010, Instrument Specialists, Inc., Spring Grove, IL). Protein paste (10-15 $\mu \mathrm{g})$ was spread onto an aluminum pan (Instrument Specialists Inc., $4 \mathrm{~mm}$ crimp/en cap), hermetically sealed and placed in the scanner immediately after paste development. The sample was run against an empty container while the temperature in the scanner increased from $5{ }^{\circ} \mathrm{C}$ to $90^{\circ} \mathrm{C}$ at a rate of $10{ }^{\circ} \mathrm{C} / \mathrm{min}$. Each tested formulation was individually replicated at least 3 times. Infinite Software (Instrument Specialists Inc., Twin Lakes, WI, USA) was used to draw the thermograms and to analyze the data points.

\subsection{MP Gel Preparation}

In order to facilitate protein gelation, the stainless steel tubes containing the protein paste were stored at $4^{\circ} \mathrm{C}$ for $24 \mathrm{~h}$ prior to cooking. The tubes were cooked at $90{ }^{\circ} \mathrm{C}$ for $20 \mathrm{~min}$ in a water bath (Precision, Jouan Inc, Wincester, Virginia) and chilled on ice for 15 min upon being removed. The tubes were then stored at room temperature (approximately $23^{\circ} \mathrm{C}$ ) for $1 \mathrm{~h}$ to allow the gels to adjust to room temperature. After being removed from the tubes, the gel samples were cut and immediately analyzed.

2.7. Texture Profile Analysis (TPA)

Textural properties (hardness, springiness, cohesiveness, gumminess, chewiness and resilience) of MP gels were analyzed using a texture analyzer (Model TA-HDi, Texture Technologies Corp., Scarsdale, NY, USA) with a $70 \mathrm{~mm}$ TPA compression plate attachment. The data from 12 cylindrical gel samples (length $2.54 \mathrm{~cm}$, diameter $1.9 \mathrm{~cm}$ ) analyzed by Texture Expert software (Texture Expert Exceed version 2.64, Stable Micro Systems, 2003) was presented as mean \pm standard deviation.

\subsection{Kramer Shear Cell Test}


Kramer shear stress and shear force was analyzed using a texture analyzer (Model TAHDi, Texture Technologies Corp., Scarsdale, NY, USA) with a Kramer cell attachment with five blades ( $3 \mathrm{~mm}$ thick and $70 \mathrm{~mm}$ wide). Each gel sample was weighed prior to testing. The peak force (g/g sample) was measured at $127 \mathrm{~mm} \mathrm{~min}^{-1}$ crosshead speed. Shear force was determined as a ration of peak force over the weight of the gel sample, and shear stress was calculated by dividing the force by the area of the sample. At least 6 cylindrical gel samples (length $8 \mathrm{~cm}$, diameter $1.9 \mathrm{~cm}$ ) were run for each formula and the results were analyzed using Texture Expert software (Texture Expert Exceed version 2.64, Stable Micro Systems, 2003).

\subsection{Torsion Analysis}

Torsional shear stress and shear strain at mechanical fracture was determined using a Hamman torsion meter (Gel Consultants, Raleigh, NC, USA). At least 8 samples were tested for each formula. The results were obtained using Torsion Vane (Gel Consultants, Raleigh, NC, USA) and presented as mean \pm standard deviation.

2.10. Color analysis

$L^{*}$ (lightness; scale: 0 - 100), a* (intensity in red color; scale: -60 - +60), and $b^{*}$ (intensity in yellow color; scale: $-60-+60$ ) were measured using a colorimeter (Minolta Camera Co. Ltd, Osaka, Japan) that was calibrated with a standard white plate No.21333180 (CIE L* 93.1; $\left.a^{*} 0.3135 ; b^{*} 0.3198\right)$. At least fifteen samples were tested per formulation. Whiteness of the samples was calculated using the following equation ${ }^{14}$ :

Whiteness $=100-\left[(100-\mathrm{L})^{2}+\mathrm{a}^{2}+\mathrm{b}^{2}\right]^{1 / 2}$

\subsection{Statistical Analysis}

Prior to starting experiments, the MP extraction strategy involving different processing acids and the protein paste formulation trials were randomized. The results were statistically 
analyzed with JMP software (JMP 10.2, SAS Inst., Cary, NC, USA) and analysis of variance (ANOVA) was applied. Significance level was set at $0.05(\mathrm{p}<0.05)$. The results were presented as mean \pm standard deviation. Different letters $\left({ }^{a, b, c}\right)$ indicate significant differences between mean values of gels containing $5 \mathrm{~g}$ TGase/kg paste and $10 \mathrm{~g} \mathrm{SP} / \mathrm{kg}$ protein paste with functional additives Tukey's honestly significant differences (HSD) test, $\mathrm{p}<0.05)$. Different letters $(\mathrm{x}, \mathrm{y}, \mathrm{z})$ represent significant differences in mean values of gels developed from MP recovered using LA within a column (Tukey's honestly significant differences test, $\mathrm{p}<0.05$ ). Formulae not containing any starch or polyphosphates are also compared with each other using Tukey's HSD with a significance level set at 0.05 and the differences are indicated either in bold or with an *. Italic and bold values are used to indicate significant $(\mathrm{p}<0.05)$ differences between gels developed from MP recovered using hydrochloric acid (HCL) or lactic acid (LA) and with 5 TGase/kg protein paste addition (Tukey's HSD).

3. Results and Discussion

\subsection{Thermal Changes}

Changes in MP gels as a reaction of thermally induced unfolding and aggregation was shown in Figure 1 and Table 1. The two major protein groups in MP are myosin and actin. Peak I represents the change in heat flow due to myosin head denaturation and shows that myosin head started to lose its native structure around $5.6-7.3^{\circ} \mathrm{C}$ and required $1.3-2.8 \mathrm{~J} / \mathrm{g}$ of energy as indicated by the enthalpy. Comparison of different protein paste formulae highlighted that the temperature of unfolding (Tonset) was similar among gel samples; however, SP addition with or without functional additives reduced $(\mathrm{p}<0.05)$ the energy required to denature myosin head. Similar results were reported when freeze-dried SP in MP rockfish protein had weakened the functionality of the MP gels ${ }^{20}$. It is interesting to note that Peak II which represents the thermal 
changes of the myosin tail had a wide range of Tonsets $21.4-35.2^{\circ} \mathrm{C}$, the starting point of thermal susceptibility. Although when $10 \mathrm{~g} / \mathrm{kg}$ SP was added to MP gels the myosin tail unwound at a lower temperature and the energy needed to denature that protein group was significantly greater $(\mathrm{p}<0.05)$ compared to the protein gels containing $5 \mathrm{~g}$ TGase $/ \mathrm{kg}$ developed from MP recovered using $\mathrm{HCl}$. This strategy also yielded similar enthalpy results with the protein gels containing $5 \mathrm{~g}$ TGase/kg developed from MP recovered using LA. Therefore, functional additives such as starch and polyphosphates likely have an impact on thermal unfolding of SP in MP gels. Overall, additives (starch, polyphosphates, and SP) reduced the energy required to fully denature the protein. This might be due to the MP concentration decreasing with increased functional ingredient addition. The total amount of additives including SP was kept at $23 \mathrm{~g} / \mathrm{kg}$ for every formula containing additives. Therefore, the only formula not containing any functional additives had a higher concentration of myosin and actin. This may explain the higher $(\mathrm{p}<0.05)$ thermal stability displayed by the gel containing only salt ( $20 \mathrm{~g} / \mathrm{kg}$ paste) and no other additives.

Actin on the other hand is more thermally stable compared to myosin and unfolds at higher temperatures. Peak III represents the temperature and energy needed to aggregate actin which started unraveling between $43.5-50.5^{\circ} \mathrm{C}$, which are slightly lower temperatures than were previously reported for silver carp and rockfish ${ }^{13,20}$. The enthalpy ranged from 0.2-1.7 J/g and was greatest $(\mathrm{p}<0.05)$ for gels with no additives and gels with only $23 \mathrm{~g} \mathrm{SP} / \mathrm{kg}$ paste without starch and polyphosphates. Both formulations that contained SP showed increased $(\mathrm{p}<0.05)$ thermo-stability of actin compared to TGase containing gels. Similar to the results obtained from thermal changes in myosin head and tail, protein concentration of gel samples may explain these outcomes. A previous study showed that when the SP concentration was increased from 0 to $50 \mathrm{~g} / \mathrm{kg}$ the thermal resistance of myosin and actin also increased ${ }^{20}$. In this study, the gels 
developed with $23 \mathrm{~g} / \mathrm{kg}$ SP, the energy required of actin to unfold was less than $(\mathrm{p}<0.05)$ gels containing $10 \mathrm{~g} \mathrm{SP} / \mathrm{kg}$ paste or TGase (5 g/kg). On the other hand, the gels containing the most SP tested in this study showed no significant $(p>0.05)$ differences between gels with no additives by means of enthalpy associated with actin denaturation. Therefore, protein concentration plays a significant role in thermal stability. Addition of greater amounts (>23g/kg paste) of SP may improve gel functionality because the total protein content would be increased.

Peak IV is attributed to SP in the MP gels. SP started to undergo thermal changes around 65.8-73. $3^{\circ} \mathrm{C}$. Although there weren't any significant $(\mathrm{p}>0.05)$ differences in functional additive containing formula by means of SP denaturing temperatures, it was observed that the energy required to unfold SP was higher $(\mathrm{p}<0.05)$ in gels containing $10 \mathrm{~g} \mathrm{SP} / \mathrm{kg}$ paste compared to gels also developed from LA processed MP with $5 \mathrm{~g}$ TGase/ $\mathrm{kg}$ paste. This was also reported in a previous publication where SP denaturation was not detectable in MP gels recovered at solubilization $\mathrm{pH} 11.5$ using a combination of $1: 1$ formic and lactic acid that contained $5 \mathrm{~g}$ TGase/kg paste ${ }^{13}$. It is possible that LA may be more effective in protein precipitation compared to $\mathrm{HCl}$, leading to better separation of the water soluble SP from MP. The energy required to unwind SP was the highest $(\mathrm{p}<0.05)$ in gels with no functional additives similar to the myosin tail peak data, possibly due to the higher protein concentration.

Overall, increasing the SP content in gels did not improve thermo-stability any more than gels without any additives. This may be attributed to the salt concentration in MP gels. Although the standard amount of $20 \mathrm{~g}$ salt $/ \mathrm{kg}$ paste was added, the MP recovered using $\mathrm{NaOH}$ had a greater amount of sodium in the recovered protein fraction ${ }^{21}$. The MP gels without functional additives formed comparable gels with those that had functional additives possibly due to the increased sodium in the recovered MP. On the other hand, SP was shown to be destabilized at $20 \mathrm{~g} / 100 \mathrm{~g}$ 
paste salt containing conditions, and their endothermic transition temperatures were reduced ${ }^{20}$. Therefore, effects of SP may be more pronounced in MP gels containing lower amounts of salt.

\subsection{Textural Properties}

Texture Profile Analysis (TPA) is a compression test where solid food samples are objected to a two-cycle compression-decompression similar to mastication ${ }^{22}$. The resulting force versus time curve is used to calculate textural and sensory properties of food such as hardness, springiness, cohesiveness, gumminess, chewiness, and resilience ${ }^{14}$. The textural properties observed for gels made from MP recovered using different processing acids and formulated with different additives is shown Table 2 and Figure 2. Overall, using $\mathrm{HCl}$ as a recovery acid resulted in harder, gummier, and chewier $(\mathrm{p}<0.05)$ gels and the addition of TGase yielded more cohesive $(\mathrm{p}<0.05)$ gels independent of the MP recovery acid used. Hardness, gumminess, and chewiness was reduced $(\mathrm{p}<0.05)$ in gels made with SP or no additives among gels made with MP recovered with LA. Furthermore, gels were most resilient $(\mathrm{p}<0.05)$ when $10 \mathrm{~g} / \mathrm{kg}$ SP was added. This strategy also yielded more cohesive gels $(\mathrm{p}<0.05)$ compared to gels without functional additives such as starch and polyphosphates. Therefore, functional additives are necessary for a cohesive gel network formation.

The impact of SP on textural characteristics may be more apparent if greater concentrations of SP were used in the formulations ${ }^{9}$. A previous study reported that addition of $20 \mathrm{~g} \mathrm{SP} / \mathrm{kg}$ paste did not affect resistance to deformation of Pollock surimi gels compared to gels containing no SP or $20 \mathrm{~g}$ sucrose/kg paste. In this current study, although $23 \mathrm{~g} \mathrm{SP} / \mathrm{kg}$ protein paste containing gels were less resistant to breaking at axial point compared to TGase containing gels, they showed increased resistance to deformation compared to gels containing no additives. The same study investigating the effects of $20 \mathrm{~g} \mathrm{SP} / \mathrm{kg}$ paste addition into Pollock surimi gels 
reported that SP had hardened the gels ${ }^{20}$. As previously explained, SP loses its functionality at high salt concentrations (20g/kg paste). In our study MP gels solubilized using $\mathrm{NaOH}$ had higher sodium content compared to ground catfish as well as Alaska Pollock surimi even prior to adding $20 \mathrm{~g}$ salt $/ \mathrm{kg}$ paste. Adding $20 \mathrm{~g}$ salt $/ \mathrm{kg}$ paste during paste development increased salt concentration furthermore, thus possibly denaturing SP.

TPA results were supported by Kramer Shear data. Addition of TGase in gels developed from MP recovered using $\mathrm{HCl}$ showed significantly more $(\mathrm{p}<0.05)$ shear force indicating gel strength. Comparison of formulations developed using MP recovered with LA showed that addition of TGase also resulted in stronger gels $(\mathrm{p}<0.05)$. Moreover, shear stress, an indicator of the susceptibility to deformation when a force is applied on the same direction ${ }^{24}$, was greatest for gels made with TGase gels made with MP recovered with LA when compared to the gels that contained functional additives. However, when all formulations were tested, there were no significant differences $(\mathrm{p}>0.05)$.

Torsional testing is used to detect into the inner flaws of the food product, especially in the gel matrix which cannot be seen or determined by shear cell testing ${ }^{25}$. Torsional shear stress and strain observations confirmed the previous textural measurements where SP addition less stress and strain $(\mathrm{p}<0.05)$ compared to gels containing TGase. There were no statistical differences ( $p>0.05)$ between gels made with TGase regardless of the MP recovery acid. Both shear stress and shear strain were statistically similar $(\mathrm{p}>0.05)$ between gels containing SP and no additives. On the other hand, torsional shear strain was greater for $23 \mathrm{~g} \mathrm{SP} / \mathrm{kg}$ paste containing gels compared to gels having no additives; therefore, the resistance of gels to deformation may be increased with the addition of a greater amount of SP. 
These results may be due to SP interfering with the gel network formation by binding actomyosin which is the major protein complex responsible for a viscous gel formation ${ }^{26,27}$. During protein paste development, actin filament and myosin bind to form actomyosin complex ${ }^{28}$. Protein gelation starts when actomyosin undergoes irreversible structural changes when subjected to heat, including denaturation and then aggregation ${ }^{27,28,29}$. Among many factors affecting MP gelation; i.e., the differences in compositions of MP and SP extracted from different fish species, the protein recovery method, protein concentration, heating rate, the $\mathrm{pH}$ of the protein paste, salt concentration, the functional additives included in the protein paste, etc., may have played a significant role in this study ${ }^{30}$. For the most part, SP did not improve textural properties in black bullhead catfish MP gels in the amounts tested in this study; however, gelation occurred when SP was added into MP. It is indicated in a previously conducted study that softer texture is preferred for soybean curd ${ }^{31}$; therefore, SP addition will be beneficial by increasing protein amount in gels where softer texture is desirable.

\subsection{Color}

Color properties of the gel samples, where L* shows lightness, $\mathrm{a}^{*}$ indicates the intensity of red color, and $b^{*}$ measures the intensity of yellow color, are provided in Table 4 . The addition of SP increased $(\mathrm{p}<0.05)$ lightness shown by $\mathrm{L}^{*}$ in all gel formulations. This may have been due to the naturally light color of the SP powder or by the light reflecting from the less firm gel network. Moreover, $\mathrm{b}^{*}$ which indicates yellowness was also higher in SP containing gels, possibly due to the heme-proteins associated with SP.

It is also important to note the changes in color when different processing acids are used to recover MP. For example, the gel samples made with MP recovered using $\mathrm{HCl}$ during protein precipitation contained more redness $(\mathrm{p}<0.05)$ likely due to poorer separation of hemoglobin. 
Along with that, adding functional ingredients increased $(\mathrm{p}<0.05)$ redness of the gels. Whereas, gels were more yellow $(\mathrm{p}<0.05)$ in MP gels made with the protein recovered using LA compared to $\mathrm{HCl}$. Although, heme proteins associated with SP likely increased $(\mathrm{p}<0.05)$ yellowness, addition of SP also increased lightness and therefore, gels containing SP were whiter $(\mathrm{p}<0.05)$. Whiteness of gels ranged from 47-58, where MP recovered with LA and TGase added were less white $(\mathrm{p}<0.05)($ Table 3$)$. SP as an additive in gels significantly increased $(\mathrm{p}<0.05)$ whiteness and the whitest $(\mathrm{p}<0.05)$ values were observed in gels containing $23 \mathrm{~g} / \mathrm{kg}$ SP. These findings are contradictory of previously published data where whiteness was reduced with the addition of $20 \mathrm{~g} / \mathrm{kg}$ SP to Pollock surimi ${ }^{20}$. Fish species and the composition of SP recovered play a significant role in the color outcomes. MP recovered from black bullhead catfish in this study was darker when compared to other studies with different species of fish ${ }^{20}$. Therefore, the visibly whiter SP powder may have helped lighten the color of black bullhead catfish MP.

\section{Conclusions}

Although SP addition did not adversely affect thermal stability of MP gels, textural properties (except for resilience) were not improved in SP containing gels compared to gels developed using TGase. Adding SP to MP gels will increase the total protein amount, and may naturally whiten gels made from darker meat; therefore, SP incorporation may be useful in products where softer texture is preferable. Efficacy of protein gelation depends on a variety of factors such as gelation temperature, time, and composition of the gels especially salt amount. Since SP binds to MP during protein gelation, it may take longer time for SP containing gels to form a firm network. Therefore, studies that investigate the effect of sodium, increased amounts of SP and longer setting times in MP gels and their impact on textural and functional properties should be explored. 
5. Abbreviations

MP: Myofibrillar protein

SP: Sarcoplasmic protein

$\mathrm{HCl}$ : Hydrochloric acid

LA: Lactic acid

$\mathrm{NaOH}$ : Sodium hydroxide

TGase: Transglutaminase

DSC: Differential scanning calorimetry

TPA: Texture profile analysis

PP: Polyphosphates

6. Acknowledgements

This work was funded by the HATCH Program Project \# (WVA 00622). 


\section{References}

1. Park, J. W. Surimi and fish protein isolate. In Seafood Industry: Species, Products, Processing, and Safety (2nd Edition); Flick, G. J.; Granata, L. A.; Martin, R. E., Eds.: John Wiley \& Sons: West Sussex, UK, 2012; pp.118-126.

2. Bourtoom, T.; Chinnan, M. S.; Jantawat, P.; Sanguandeeku, R. Recovery and characterization of proteins precipitated from surimi wash-water. LWT-Food Sci. Technol. 2009, 42, 599-605.

3. Guenneugues, P.; Morrissey, M.T. Surimi resources. In Surimi and Surimi Seafood (2nd Edition); Park, J.W., Ed.: Taylor \& Francis Group: Boca Raton, FL, USA, 2005; pp. 3-32.

4. Ducepta, F., de Brouckera, T., Soulied, J.M., Trystrama, G., Cuveliera, G. Influence of the mixing process on surimi seafood paste properties and structure. J. Food Eng. 2012, 108(4), 557562.

5. Stine, J. J.; Pedersen, L.; Simley, S; Bechtel, P.J. Recovery and utilization of protein derived from surimi wash-water. J. Food Qual. 2012, 35, 43-50.

6. Lin, T. M.; Park, J. W.; Morrissey, M. T. Recovered protein and reconditioned water from surimi processing waste. J. Food Sci. 1995, 60, 4-9.

7. Morrissey, M. T.; Park, J. W.; Huang, L. Surimi processing waste. Its control and utilization. In Surimi and Surimi Seafood; Park, J. W., Ed.: Marcel Dekker, New York, NY, USA, 2000; pp.127-165.

8. Park, J. W.; Morrissey, M. T. Manufacturing of surimi from light muscle fish. In Surimi and Surimi Seafood; Park, J. W., Ed.: Marcel Dekker, New York, NY, USA, 2000: pp. 23-58.

9. Paker, I.; Matak, K. E. Impact of Sarcoplasmic Protein Recovered from Fish Processing Wash Water on Texture of Protein Gels. LWT-Food Sci. Technol. In review.

10. Paker, I.; Beamer, S.; Jaczynski, J.; Matak, K. E. Compositional characteristics of materials recovered from headed gutted silver carp (Hypophthalmichthys molitrix) by isoelectric solubilization and precipitation using organic acids. J. Food Sci. 2013, 78 (3), E445-E451.

11. Paker, I.; Jaczynski, J.; Matak, K. E. Calcium hydroxide as a potential base in alkali aided ph shift process. J. Agr. Food Chem. In Review.

12. Chanarat, S.; Benjakul, S. Impact of microbial transglutaminase on gelling properties of Indian mackerel fish protein isolates. Food Chem. 2013, 136 (2), 929-937.

13. Paker, I.; Beamer, S.; Jaczynski, J.; Matak, K. E. The effect of organic acids on gelation characteristics of protein gels made from silver carp (Hypophthalmichthys molitrix) protein recovered by isoelectric solubilization and precipitation. LWT - Food Sci. Technol. 2013, 53, 3743.

14. Paker, I.; Beamer, S.; Jaczynski, J.; Matak, K. E. pH shift protein recovery with organic acids on texture and color of cooked gels. J Sci. Food Agr. 2015, 95, 275-280. 
15. Jafarpour, A.; Gorczyca, E.M. Characteristics of sarcoplasmic proteins and their interaction with surimi and kamaboko gel. J Food Sci. 2009, 74, N16-N22.

16. Piyadhammaviboon, P.; Yongsawatdigul, J. Proteinase inhibitory activity of sarcoplasmic proteins from threadfin bream (Nemipterus spp.). J. Sci. Food Agric. 2010, 90, 291-298.

17. Gehring, C.K.; Gigliotti, J. C.; Moritz, J. S.; Tou, J. C.; Jaczynski, J. Functional and nutritional characteristics of proteins and lipids recovered by isoelectric processing of fish byproducts and low-value fish: A review. Food Chem. 2011, 124, 422-431.

18. Paker, I.; Matak, K.E. Influence of pre-cooking protein paste gelation conditions and postcooking gel storage conditions on gel texture. J. Sci. Food Agr. 2015, DOI: 10.1002/jsfa.7091.

19. Mac Donald, G A.; Lanier, T. C. Actomyosin stabilization to freeze-thaw and heat denaturation by lactate salts. J. Food Sci. 1994, 59, 101-104.

20. Young, K. S.; Yongsawatdigul, J.; Park, J. W.; Thawornchinsombut, S. Characteristics of sarcoplasmic proteins and their interaction with myofibrillar proteins. J. Food Biochem. 2005, $29,517-532$.

21. Paker, I. Calcium Enhanced Protein Recovery from Black Bullhead Catfish Using Organic Acids. In Calcium enhanced protein recovery from underutilized aquatic resources and optimizing protein gelation strategies using functional ingredients, $\mathrm{PhD}$ Dissertation submitted to Animal and Nutritional Sciences Department at West Virginia University, 2015.

22. Friedman, H. H.; Whitney, J. E.; Szczesniak, A. The Texturometer-A New instrument for objective texture measurement. J. Food Sci. 1963, 28, 390-395.

23. Bourne, M. Guidelines and conditions for testing foods. In Food Texture and Viscosity: Concept and Measurement; Bourne, M. Ed.: Academic Press, San Diego, CA, USA, 2002: pp. 353-362.

24. Aussanasuwannakul, A.; Slider, S. D.; Salem, M.; Yao, J.; Kenney, P. B. Comparison of Variable-Blade to Allo-Kramer Shear method in assessing rainbow trout (Oncorhynchus mykiss) fillet firmness. J Food Sci. 2012, 77, S335- S341.

25. Bourne, M. Principles of objective texture measurement. In Food Texture and Viscosity: Concept and Measurement; Bourne, M. Ed.: Academic Press, San Diego, CA, USA, 2002: pp. 107-189.

26. Shimizu, Y.; Nishioka, F. Interactions between horse mackerel actomyosin and sarcoplasmic proteins during heat coagulation. Nippon Suisan Gakk., 1974, 40, 231-234.

27. Dong, X. P.; Ma, L. L.; Zheng, J.; Wang, J. T.; Wu, Q.; Song, S.; Zhou, D. Y. Effect of pH on the physicochemical and heat-induced gel properties of scallop Patinopecten yessoensis actomyosin. Fish Sci. 2014, 80, 1073-1082. 
28. Role of the actin-myosin catch bond on actomyosin aggregate formation. Cell. Mol. Bioeng. 2013, 6, 3-12.

29. Ding, Y.; Liu, R.; Rong, J.; Liu, Y.; Zhao, S.; Xiong, S. Rheological behavior of heatinduced actomyosin gels from yellowcheek carp and grass carp. Eur. Food Res. Technol. 2012, $235,245-251$.

30. Sun, X.D.; Holley, R.A. Factors influencing gel formation by myofibrillar proteins in muscle foods. Compr. Rev. Food Sci. F. 2011, 10, 33-51.

31. Lu, J. Y; Carter, E.; Chung, R. A. Use of calcium salts for soybean curd preparation. J. Food Sci. 1980, 45, 32-34. 


\section{Figure Captions}

Figure 1. Differential scanning calorimetry (DSC) thermograms of black bullhead catfish protein pastes developed using different additives.

Figure 2. Kramer shear stress (kPa), Kramer shear force (g/g muscle), torsional shear stress (kPa) and torsional shear strain $(\mathrm{kPa})$ of recovered black bullhead catfish protein gels. Different statistical analysis results are shown. 


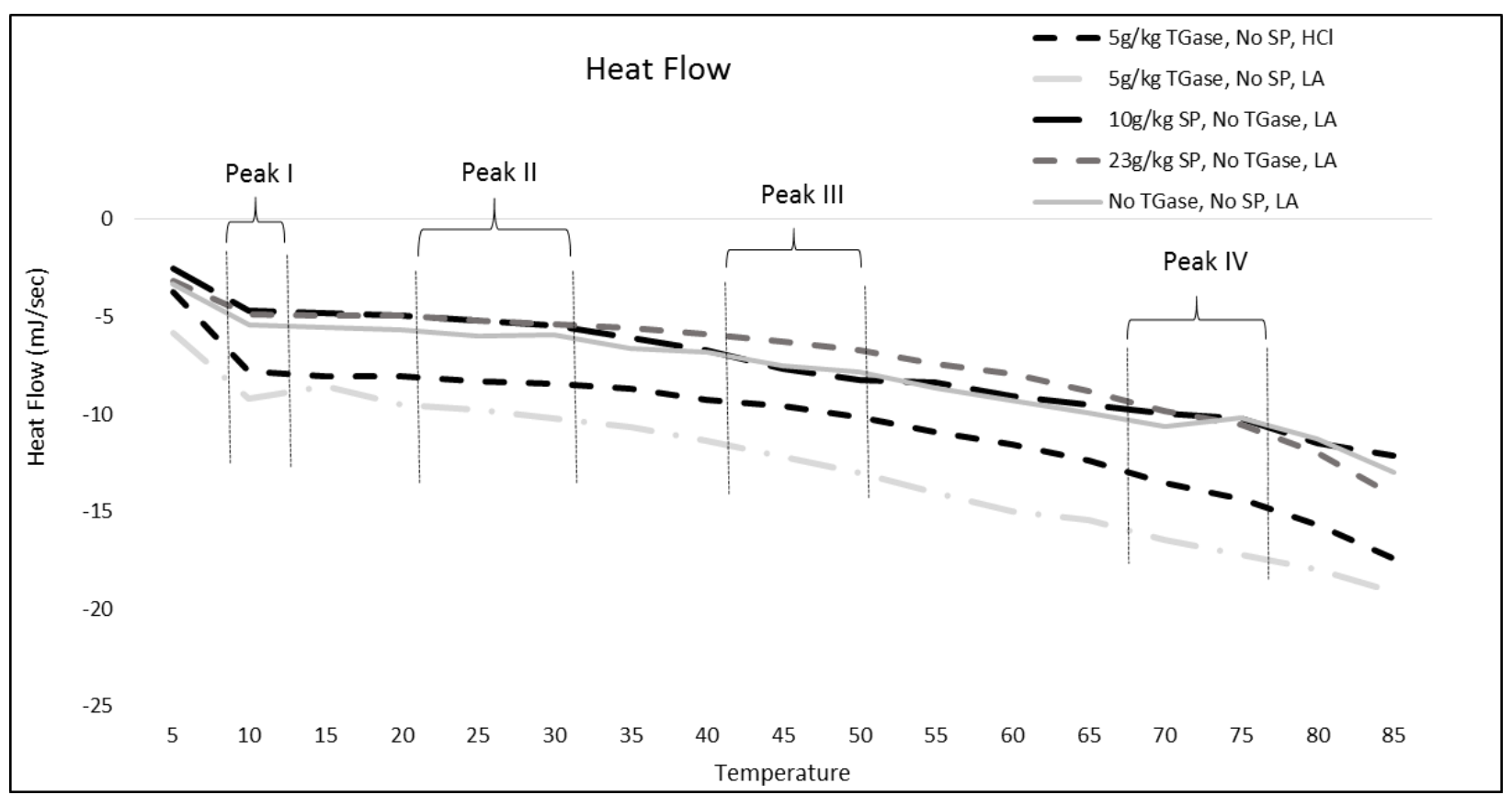

Figure 1. Differential scanning calorimetry (DSC) thermograms of black bullhead catfish protein pastes developed using different additives. Each curve was drawn using the mean of data points collected from 4 individual replications. 


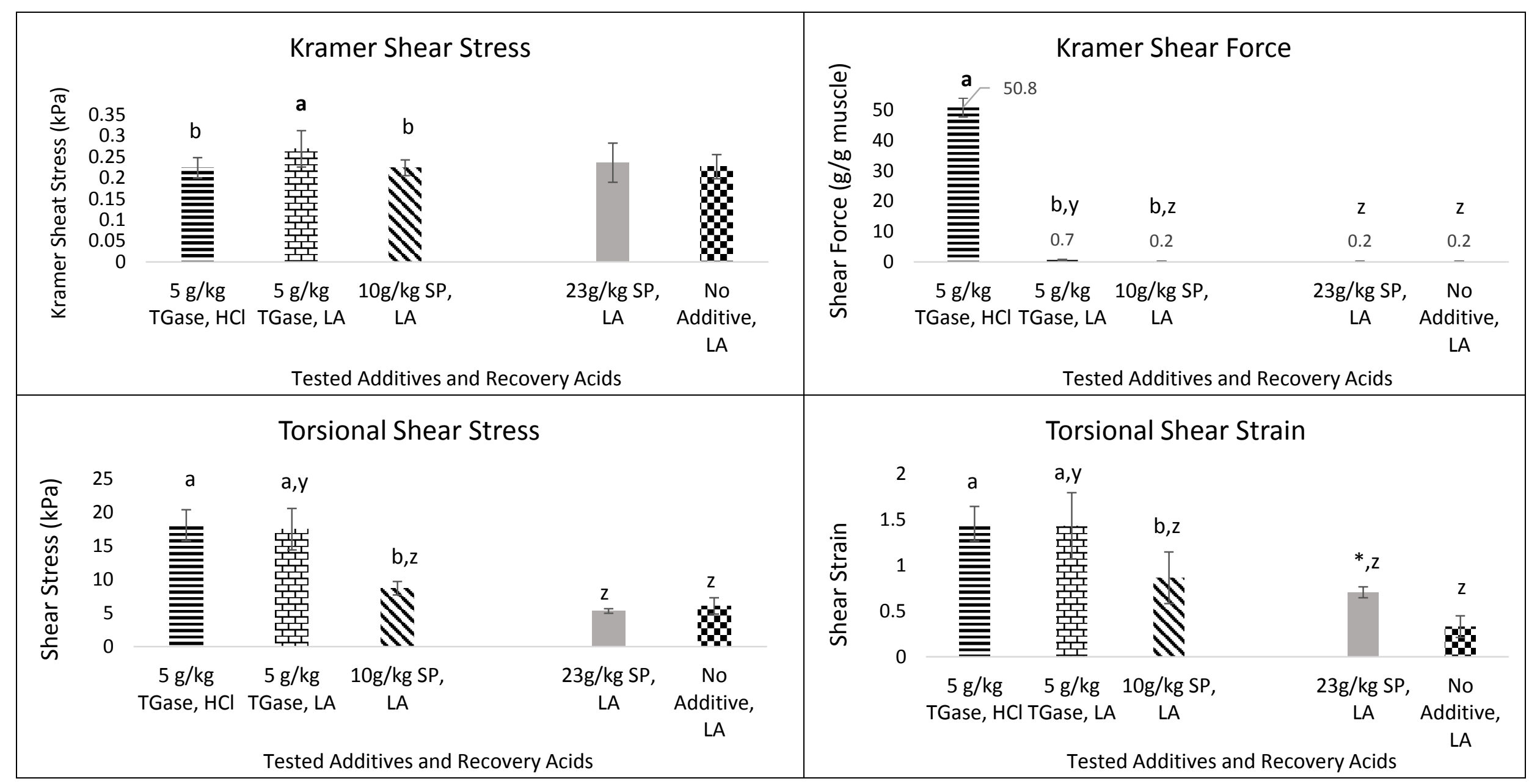

Figure 2. Kramer shear stress (kPa), Kramer shear force (g/g muscle), torsional shear stress ( $\mathrm{kPa}$ ) and torsional shear strain $(\mathrm{kPa})$ of recovered black bullhead catfish protein gels. Data are given as mean \pm standard deviation. ${ }^{\mathrm{a}, \mathrm{b}, \mathrm{c}}$ indicate significant differences between mean values of gels containing $5 \mathrm{~g}$ TGase/kg paste and $10 \mathrm{~g} \mathrm{SP} / \mathrm{kg}$ protein paste (Tukey’s honestly significant differences (HSD) test, $\mathrm{p}<0.05$ ). ${ }^{\mathrm{x}, \mathrm{y}, \mathrm{z}} \mathrm{Mean}$ values of lactic acid (LA) recovered MP gels with different letters in a column are significantly different (Tukey's HSD, p<0.05). * indicate significant $(\mathrm{p}<0.05)$ differences between gels made using no functional additives (starch, and polyphosphates $(\mathrm{PP})$ ). Bold values indicate significant $(\mathrm{p}<0.05)$ differences between gels developed from MP recovered using hydrochloric acid (HCL) or LA and with 5 TGase/kg protein paste addition. 
Table 1. Differential scanning calorimetry (DSC) measurements (temperature onset (Tonset), maximum temperature (Tmax), and net enthalpy) of isoelectrically recovered black bullhead catfish protein pastes developed using different additives. Peak I and II represent the heat flow required to unfold myosin head and tail respectively. Peak III and IV represent the heat flow required to unfold actin and sarcoplasmic protein respectively.

\begin{tabular}{|c|c|c|c|c|c|c|c|c|c|c|}
\hline \multirow[b]{2}{*}{$\begin{array}{l}\text { TGase } \\
(\mathrm{g} / \mathrm{kg})\end{array}$} & \multirow[b]{2}{*}{$\begin{array}{c}\mathrm{SP} \\
(\mathrm{g} / \mathrm{kg})\end{array}$} & \multirow[b]{2}{*}{$\begin{array}{l}\text { Starch } \\
(\mathrm{g} / \mathrm{kg})\end{array}$} & \multirow[b]{2}{*}{$\begin{array}{c}\mathrm{PP} \\
(\mathrm{g} / \mathrm{kg})\end{array}$} & \multirow[b]{2}{*}{ Acid } & \multicolumn{3}{|c|}{ Peak I } & \multicolumn{2}{|r|}{ Peak II } & \multirow[b]{2}{*}{ Enthalpy (J/g) } \\
\hline & & & & & Tonset $\left({ }^{\circ} \mathrm{C}\right)$ & $\operatorname{Tmax}\left({ }^{\circ} \mathrm{C}\right)$ & Enthalpy $(\mathrm{J} / \mathrm{g})$ & Tonset $\left({ }^{\circ} \mathrm{C}\right)$ & $\operatorname{Tmax}\left({ }^{\circ} \mathrm{C}\right)$ & \\
\hline 5 & 0 & 15 & 3 & $\mathrm{HCl}$ & $6.63 \pm 0.51$ & $7.35 \pm 0.53 b$ & $2.70 \pm 0.28 \mathrm{a}$ & $35.17 \pm 1.49$ a & $38.71 \pm 2.43$ a & $0.23 \pm 0.03 b$ \\
\hline 5 & 0 & 15 & 3 & LA & $7.33 \pm 0.16 x$ & $10.61 \pm 0.14 a, y$ & $2.81 \pm 0.35 \mathrm{a}, \mathrm{y}$ & $29.90 \pm 0.44 b, y$ & $34.59 \pm 0.41 \mathrm{a}, \mathrm{y}$ & $0.27 \pm 0.07 a b, z$ \\
\hline 0 & 10 & 10 & 3 & LA & $6.64 \pm 1.25 x y$ & $10.69 \pm 0.43 a, y$ & $1.30 \pm 0.18 \mathrm{~b}, \mathrm{z}$ & $21.42 \pm 2.69 \mathrm{c}, \mathrm{z}$ & $25.40 \pm 4.98 b, z$ & $0.33 \pm 0.02 a, z$ \\
\hline 0 & 23 & 0 & 0 & LA & $5.56 \pm 0.27 z$ & $10.16 \pm 0.58 y$ & $1.70 \pm 0.16 z$ & $30.68 \pm 1.93$ y & $33.64 \pm 1.32$ y & $0.18 \pm 0.07 z$ \\
\hline 0 & 0 & 0 & 0 & LA & $5.79 \pm 0.40 y z$ & $6.84 \pm 0.69 \mathrm{z}$ & $2.60 \pm 0.22 y$ & $27.08 \pm 2.15 \mathrm{y}$ & $35.34 \pm 1.06$ y & $0.62 \pm 0.08 y$ \\
\hline \multirow[b]{2}{*}{$\begin{array}{l}\text { TGase } \\
(\mathrm{g} / \mathrm{kg})\end{array}$} & \multirow[b]{2}{*}{$\begin{array}{c}\mathrm{SP} \\
(\mathrm{g} / \mathrm{kg}) \\
\end{array}$} & \multirow[b]{2}{*}{$\begin{array}{l}\text { Starch } \\
(\mathrm{g} / \mathrm{kg})\end{array}$} & \multirow[b]{2}{*}{$\begin{array}{c}\mathrm{PP} \\
(\mathrm{g} / \mathrm{kg})\end{array}$} & \multirow[b]{2}{*}{ Acid } & \multicolumn{3}{|c|}{ Peak III } & \multicolumn{3}{|c|}{ Peak IV } \\
\hline & & & & & Tonset $\left({ }^{\circ} \mathrm{C}\right)$ & $\operatorname{Tmax}\left({ }^{\circ} \mathrm{C}\right)$ & Enthalpy $(\mathrm{J} / \mathrm{g})$ & Tonset $\left({ }^{\circ} \mathrm{C}\right)$ & $\operatorname{Tmax}\left({ }^{\circ} \mathrm{C}\right)$ & Enthalpy $(\mathrm{J} / \mathrm{g})$ \\
\hline 5 & 0 & 15 & 3 & $\mathrm{HCl}$ & $43.48 \pm 2.61 \mathrm{~b}$ & $53.29 \pm 5.21$ & $0.18 \pm 0.05 b$ & $68.73 \pm 0.72$ & $74.63 \pm 5.81$ & $1.24 \pm 0.34 \mathrm{a}$ \\
\hline 5 & 0 & 15 & 3 & LA & $50.48 \pm 0.40 a$ & $52.71 \pm 1.42 \mathrm{z}$ & $0.23 \pm 0.01 b, z$ & $68.83 \pm 0.08 \mathrm{yz}$ & $74.46 \pm 1.85 y z$ & $0.68 \pm 0.08 b, z$ \\
\hline 0 & 10 & 10 & 3 & LA & $49.41 \pm 3.60 \mathrm{ab}$ & $53.17 \pm 4.50 \mathrm{z}$ & $0.66 \pm 0.13 a, z$ & $65.81 \pm 4.62 \mathrm{z}$ & $73.50 \pm 5.67 \mathrm{z}$ & $1.48 \pm 0.04 \mathrm{a}, \mathrm{y}$ \\
\hline 0 & 23 & 0 & 0 & LA & $47.67 \pm 1.34$ & $55.99 \pm 2.10 \mathrm{z}$ & $1.56 \pm 0.29 y$ & $69.02 \pm 2.03 y z$ & $76.18 \pm 1.24 y z$ & $1.08 \pm 0.26 \mathrm{yz}$ \\
\hline 0 & 0 & 0 & 0 & LA & $50.33 \pm 4.83$ & $62.11 \pm 0.89 y$ & $1.68 \pm 0.08$ y & $73.28 \pm 3.64 y$ & $80.3 \pm 0.82$ y & $2.52 \pm 0.16 \times$ \\
\hline
\end{tabular}

a,b,c indicate significant differences between mean values of gels containing $5 \mathrm{~g}$ TGase/kg paste and $10 \mathrm{~g}$ SP/kg protein paste with functional additives. ${ }^{\mathrm{x}, \mathrm{y}, \mathrm{z}}$ Mean values obtained from gels developed from MP recovered using lactic acid (LA) with different letters in a column are significantly different (Tukey's honestly significant differences test, $\mathrm{p}<0.05$ ).

Bold values indicate significant $(\mathrm{p}<0.05)$ differences between gels made using no functional additives (starch, and polyphosphates $(\mathrm{PP})$ ). Italic and bold values indicate significant $(\mathrm{p}<0.05)$ differences between gels developed from MP recovered using hydrochloric acid (HCL) or lactic acid (LA) and with $5 \mathrm{TGase} / \mathrm{kg}$ protein paste addition. 
Table 2. Hardness, Springiness, Cohesiveness, Gumminess, Chewiness and Resilience (texture profile analysis) of gels. Data are given as mean \pm standard deviation.

\begin{tabular}{|c|c|c|c|c|c|c|c|c|c|c|}
\hline $\begin{array}{l}\text { TGase } \\
(\mathrm{g} / \mathrm{kg})\end{array}$ & $\begin{array}{c}S P \\
(\mathrm{~g} / \mathrm{kg})\end{array}$ & $\begin{array}{l}\text { Starch } \\
(\mathrm{g} / \mathrm{kg})\end{array}$ & $\begin{array}{c}P P \\
(\mathrm{~g} / \mathrm{kg})\end{array}$ & Acid & $\begin{array}{l}\text { Hardness } \\
\text { (g) }\end{array}$ & $\begin{array}{l}\text { Springiness } \\
(\mathrm{mm})\end{array}$ & $\begin{array}{c}\text { Cohesiveness } \\
\text { (Ratio) }\end{array}$ & $\begin{array}{c}\text { Gumminess } \\
\text { (g) }\end{array}$ & $\begin{array}{l}\text { Chewiness } \\
\text { (g mm) }\end{array}$ & $\begin{array}{l}\text { Resilience } \\
\text { (Ratio) }\end{array}$ \\
\hline 5 & 0 & 15 & 3 & $\mathrm{HCl}$ & $1057.78 \pm 81.60 a$ & $2.03 \pm 0.03$ & $0.60 \pm 0.08 a$ & $699.08 \pm 133.13 a$ & $1413.36 \pm 258.11 a$ & $0.39 \pm 0.03 b$ \\
\hline 5 & 0 & 15 & 3 & LA & $11.30 \pm 2.02 b, y$ & $1.92 \pm 0.27 \mathrm{yz}$ & $0.55 \pm 0.09 a, x$ & $4.38 \pm 2.88 \mathrm{~b}, \mathrm{y}$ & $13.73 \pm 3.90 \mathrm{~b}, \mathrm{y}$ & $0.33 \pm 0.04 b, y$ \\
\hline 0 & 10 & 10 & 3 & LA & $2.05 \pm 0.31 b, z$ & $2.12 \pm 0.28 y$ & $0.29 \pm 0.08 b, y$ & $0.55 \pm 0.13 b, z$ & $1.20 \pm 0.18 b, z$ & $0.80 \pm 0.19 a, x$ \\
\hline 0 & 23 & 0 & 0 & LA & $1.43 \pm 0.43 z$ & $1.67 \pm 0.003 \mathrm{z}$ & $0.21 \pm 0.04 z$ & $0.35 \pm 0.14 z$ & $0.61 \pm 0.24 z$ & $0.07 \pm 0.02 z$ \\
\hline 0 & 0 & 0 & 0 & LA & $1.21 \pm 0.11 \mathrm{z}$ & $1.68 \pm 0.01 \mathrm{z}$ & $0.21 \pm 0.02 \mathrm{z}$ & $0.24 \pm 0.05 \mathrm{z}$ & $0.43 \pm 0.09 \mathrm{z}$ & $0.07 \pm 0.008 z$ \\
\hline
\end{tabular}

a,b,c indicate significant differences between mean values of gels containing $5 \mathrm{~g}$ TGase/kg paste and $10 \mathrm{~g}$ SP/kg protein paste with functional additives. ${ }^{\mathrm{x}, \mathrm{y}, \mathrm{z}}$ Mean values obtained from gels developed from MP recovered using lactic acid (LA) with different letters in a column are significantly different (Tukey's honestly significant differences test, $\mathrm{p}<0.05$ ).

Bold values indicate significant $(\mathrm{p}<0.05)$ differences between gels made using no functional additives (starch, and polyphosphates $(\mathrm{PP})$ ). Italic and bold values indicate significant $(\mathrm{p}<0.05)$ differences between gels developed from MP recovered using hydrochloric acid (HCL) or lactic acid (LA) and with 5 TGase/kg protein paste addition. 
Table 3. Color properties and whiteness of recovered black bullhead catfish protein gels, where L* indicates lightness (scale: 0-100), $a^{*}$ measures the intensity of red color (scale: -60 to +60 ), and $b^{*}$ shows the intensity of yellow color (scale: -60 to +60 ).

\begin{tabular}{|c|c|c|c|c|c|c|c|c|}
\hline TGase $(\mathrm{g} / \mathrm{kg})$ & $\mathrm{SP}(\mathrm{g} / \mathrm{kg})$ & Starch $(\mathrm{g} / \mathrm{kg})$ & $\mathrm{PP}(\mathrm{g} / \mathrm{kg})$ & Acid & $\mathrm{L}^{*}$ & $a^{*}$ & $b^{*}$ & Whiteness \\
\hline 5 & 0 & 15 & 3 & $\mathrm{HCl}$ & $55.17 \pm 1.24 b$ & $5.36 \pm 0.27 a$ & $10.16 \pm 0.50 \mathrm{c}$ & $53.71 \pm 1.22 b$ \\
\hline 5 & 0 & 15 & 3 & $\mathrm{LA}$ & $48.91 \pm 2.21 \mathrm{c}, \mathrm{z}$ & $2.98 \pm 0.67 b, x$ & $12.76 \pm 0.74 b, z$ & $47.24 \pm 2.11 \mathrm{c}, \mathrm{z}$ \\
\hline 0 & 10 & 10 & 3 & LA & $58.56 \pm 0.91 a, x$ & $3.22 \pm 0.70 b, x$ & $16.33 \pm 0.39 a, x$ & $55.33 \pm 0.79 a, x$ \\
\hline 0 & 23 & 0 & 0 & LA & $61.48 \pm 1.34 \mathrm{w}$ & $0.19 \pm 0.41$ y & $16.07 \pm 0.49 x$ & $58.26 \pm 1.22 \mathrm{w}$ \\
\hline 0 & 0 & 0 & 0 & $\mathrm{LA}$ & $56.29 \pm 0.88$ y & $-0.66 \pm 0.59 z$ & $13.43 \pm 0.77 y$ & $54.26 \pm 0.80 y$ \\
\hline
\end{tabular}

$\overline{\mathrm{a}, \mathrm{b}, \mathrm{c}}$ indicate significant differences between mean values of gels containing $5 \mathrm{~g}$ TGase/kg paste and $10 \mathrm{~g}$ SP/kg protein paste with

functional additives. ${ }^{\mathrm{x}, \mathrm{y}, \mathrm{z}}$ Mean values obtained from gels developed from MP recovered using lactic acid (LA) with different letters in a column are significantly different (Tukey's honestly significant differences test, $\mathrm{p}<0.05$ ).

Bold values indicate significant $(\mathrm{p}<0.05)$ differences between gels made using no functional additives (starch, and polyphosphates $(\mathrm{PP})$ ). Italic and bold values indicate significant $(\mathrm{p}<0.05)$ differences between gels developed from MP recovered using hydrochloric acid (HCL) or lactic acid (LA) and with $5 \mathrm{TGase} / \mathrm{kg}$ protein paste addition. 


\title{
CHAPTER 7
}

\section{Sarcoplasmic Protein Powder as an Additive in Calcium Enhanced Catfish Protein Gels}

\author{
Abstract
}

Sarcoplasmic proteins (SP) were recovered from ground, black bullhead catfish by dilution with distilled/deionized water and then dried to a powder. Myofibrillar protein (MP) was isolated from ground catfish using a $\mathrm{pH}$ shift method. Protein solubilization was achieved at $\mathrm{pH}$ 11.0 with calcium hydroxide $\left(\mathrm{Ca}(\mathrm{OH})_{2}\right)$ or sodium hydroxide $(\mathrm{NaOH})$; the isoelectric point $(\mathrm{pH}$ 5.5) was reached using lactic acid for MP precipitation. SP powder was added to MP at 0,5 , or $23 \mathrm{~g} / \mathrm{kg}$ protein paste. Functional, textural and color properties of gels made with SP addition were compared to MP gels containing $5 \mathrm{~g}$ microbial transglutaminase (TGase)/kg protein paste. Effects of using different processing bases during MP recovery were assessed. SP addition at 23 $\mathrm{g} / \mathrm{kg}$ paste without other functional additives such as potato starch and polyphosphates improved $(\mathrm{p}<0.05)$ thermal stability of all protein groups and yielded similar textural properties (hardness, springiness, cohesiveness, gumminess, chewiness, resilience, Kramer shear stress, and torsional shear strain) as gels containing TGase made from calcium enhanced MP. Calcium enhanced MP gels containing TGase were harder, gummier, chewier, and whiter $(\mathrm{p}<0.05)$ then gels made with $\mathrm{NaOH}$ recovered MP. Gels made with $\mathrm{Ca}(\mathrm{OH})_{2}$ were whiter compared to $\mathrm{NaOH}$ processed $\mathrm{MP}$ gels. MP recovery using $\mathrm{Ca}(\mathrm{OH})_{2}$ may improve gelation conditions by catalyzing protein-protein interactions through enhanced calcium dependent endogenous TGase activity. Gels may benefit from the addition of greater amounts (>20 g/ $\mathrm{kg}$ paste) of SP addition, and formulae using SP in combination with functional additives should be investigated.

Keywords: calcium hydroxide, lactic acid, protein gel, sarcoplasmic protein, texture, color 


\section{Introduction}

Marketability of surimi and restructured fish products are mainly defined by the gelation properties of the myofibrillar protein (MP). A gel network forms as a result of electrostatic and hydrophobic interactions, hydrogen bonds and both disulphide and non-disulphide covalent bonds that hold together a matrix of ingredients ${ }^{1}$. Textural characteristics may be enhanced with functional additives such as salt, starch, beef plasma protein, polyphosphates, and exogenous transglutaminase (TGase) that function as gel matrix binders or fillers by preventing proteolysis caused by endogenous enzymatic activity ${ }^{2,3,4}$. Therefore, the composition of a gel drives these protein-protein, protein-water and protein-lipid-water interactions which greatly impact the texture of the final product, a major criterion for assessing the desirability of the food product ${ }^{5,6}$.

Sarcoplasmic proteins (SP) are water soluble proteins that make up to $30 \mathrm{~g} / 100 \mathrm{~g}$ of all muscle protein. Although they are easily extracted, their utilization in protein gels are still questioned ${ }^{7}$. SP include glycolytic enzymes, creatine kinase, myoglobin and extracellular fluids which bind to MP, the protein mainly responsible for forming a stable gel ${ }^{8}$. The structural deformation which deteriorates gel formation properties associated with MP, majorly myosin, is attributed to the proteases ${ }^{2}$. Therefore, adding SP containing endogenous enzymes may interfere with gelation by increasing proteolytic degredation of myofibrillar protein. In addition to the proteases, other enzymes such as glyceraldehyde 3-phosphate dehydrogenase were reported to bind to MP and prevent gel formation ${ }^{9}$. On the other hand, several studies showed that adding SP increased gel strength and prevented gel softening by possibly inhibiting trypsin activity and reducing proteolytic activity ${ }^{9-12}$. The differences in observed changes in MP gels when SP used as an additive, is attributed to the different SP compositions isolated from different fish species ${ }^{9}$. 
Fish muscle protein consisting mainly of myosin and actin are isolated using a variety of methods and made into gels such as surimi. The traditional way of removing impurities and preserving the functionality of MP is to expose minced fish flesh to extensive wash cycles ${ }^{13}$. Although washing successfully removes the majority of lipids and connective tissues, waste is generated ${ }^{14}$. Moreover, the processing water contains SP which is also a source of protein and can be utilized ${ }^{15}$. Another method of protein extraction, isoelectric solubilization and precipitation (ISP), exposes the protein source to extremely high or low $\mathrm{pH}$ to solubilize protein followed by precipitation at the isoelectric point of protein. This method may be a viable alternative to surimi processing ${ }^{16}$. Using ISP, impurities can be removed and MP can be isolated without significant change to the confirmation of proteins native structure ${ }^{17,18}$.

Processing acids and bases responsible for decreasing and increasing the $\mathrm{pH}$ during ISP affects the functionality and the compositional properties (protein, lipid, impurities, and mineral content) of the recovered MP ${ }^{16}$. Organic acids such as acetic acid, and a 1:1 combination of formic and lactic acid (LA) are effective at protein precipitation during ISP. They induce less protein degradation compared to the traditionally used hydrochloric acid with the benefit of reducing possible bacterial contamination ${ }^{16-22}$. Furthermore, alkali solubilization where protein solubilization is achieved at $\mathrm{pH}$ 10.5-12.5 induces fewer conformational changes on the native structure of the protein when compared to acidic solubilization ${ }^{16-18}$. Therefore, alkali solubilization followed by precipitation with LA was applied in this study to recover MP.

Sodium hydroxide $(\mathrm{NaOH})$ is commonly used during alkali protein solubilization as the processing base because of high protein recovery yields; however, the addition of $\mathrm{NaOH}$ will increase sodium levels in the recovered MP ${ }^{23,24}$. Another processing base, calcium hydroxide $\left(\mathrm{Ca}(\mathrm{OH})_{2}\right)$, was reported to increase protein solubility and effectively remove impurities from 
MP while increasing calcium amount and decreasing sodium content ${ }^{23,24}$. Calcium enhancement in the recovered MP may impact gelation properties of MP and should be investigated. It was previously suggested that the increased concentration of a divalent salt such as $\mathrm{Ca}^{2+}$ may enhance MP cross-linking and work as a binder for aggregates by facilitating covalent and hydrogen bonds between protein molecules ${ }^{25,26}$. Furthermore, calcium enhancement may trigger endogenous transglutaminase activity and contribute to the gel matrix formation ${ }^{15}$. Therefore, adding SP to calcium enhanced MP gels may improve gelation conditions.

The aim of this study was to determine the effects of SP powder at different amounts on functional, textural and color properties of protein gels when used as an additive in calcium enhanced myofibrillar protein (MP) gels.

2. Materials and Methods

2.1. Preparation of starting material for protein pastes

Black bullhead catfish (Ameiurus melas) that were netted from runways in Dogwood Lake, Morgantown, WV were immediately placed on ice containing carbon monoxide and taken to the Meat Processing Laboratory at West Virginia University, Department of Animal and Nutritional Sciences. The fish were then washed under running tap water, gutted and washed one more time under running tap water. A food grade meat grinder (Hobart Model 4146, Troy, OH, USA) was sanitized prior to use. The fish were ground twice using a coarse grinder plate, transferred to steel trays with plastic lids, and stored overnight at $-20^{\circ} \mathrm{C}$ freezer to avoid thermal denaturation due to grinding. A finer ground fish paste was obtained by further grinding the chilled fish using the meat grinder with a fine plate. Finally, fish paste was individually weighed into freezer bags (Ziplock Freezer Bags, S.C. Johnson \& Son, Inc., Racine, Wis., U.S.A.) each containing $500 \mathrm{~g}$ fish paste, vacuum packaged (Ultravac KOCH Packaging, KOCH Supplies 
Inc., Kansas City, MO, USA) and stored at $-80^{\circ} \mathrm{C}$ until further analyses. Experiments were completed within 10 days.

\subsection{Separation of Sarcoplasmic Proteins}

Thawed (at $4^{\circ} \mathrm{C}$ for $24-48 \mathrm{~h}$ ) fish paste $(1500 \mathrm{~g}$ ) was homogenized with distilled/deionized water at a ratio of 1:3 fish to water using a homogenizer (PowerGen 700, Fisher Scientific, Pittsburgh, PA) for $15 \mathrm{~min}$. Centrifuge tubes containing the homogenized solution was spun at $10,000 \times \mathrm{G}$ for $15 \mathrm{~min}$ at $4^{\circ} \mathrm{C}$ (Sorvall RC-SB Refrigerated Superspeed Centrifuge, Du Pont, Wilmington, DE, USA). Three distinct layers formed after being centrifuged. The top layer was a very thin layer of water soluble lipids, the supernatant contained water soluble sarcoplasmic protein (SP), and the pellet contained myofibrillar protein and insolubles such as skin, bones, and scales as well as trace amounts of lipids. In order to separate SP, the supernatant was filtered through cheese cloth into freezer cups. The samples were then freeze-dryed (VirTis Freeze Dryer, SP Scientific, Stone Ridge, NY, USA) and the SP in powder form was stored at $4^{\circ} \mathrm{C}$ until further analysis.

\subsection{Myofibrillar Protein Recovery}

Myofibrillar protein was recovered by isoelectric solubilization and precipitation process (ISP) ${ }^{4,16}$. Thawed (at $4^{\circ} \mathrm{C}$ for $\left.24-48 \mathrm{~h}\right)$, ground fish $(1500 \mathrm{~g}$ ) was homogenized with distilled/deionized water $(9000 \mathrm{ml})$ in a glass beaker and homogenized (PowerGen 700, Fisher Scientific, Pittsburgh, PA). In order to increase protein-water interactions and decrease proteinprotein binding, $1 \mathrm{~N} \mathrm{Ca}(\mathrm{OH})_{2}$ or $10 \mathrm{~N} \mathrm{NaOH}$ was added to the solution to increase the $\mathrm{pH}$ from 6.7 to 11.0 (pH analyzer, Oakton, Eutech Instruments; Singapore). Following homogenization for $20 \mathrm{~min}$, the contents were poured into centrifuge bottles and spun at $10,000 \times \mathrm{G}$ for $15 \mathrm{~min}$ at $4^{\circ} \mathrm{C}$ (Sorvall RC-SB Refrigerated Superspeed Centrifuge, Du Pont, Wilmington, DE, USA). The 
lipid fraction on the top portion was removed using a metal spatula and the middle liquid portion containing MP was filtered through a cheese cloth to remove the impurities. The insoluble that were separated as a pellet at the bottom of the centrifuge tubes were discarded. The liquid portion was transferred to a glass beaker and homogenized while glacial L-lactic acid (LA) was added to reduce the $\mathrm{pH}$ to the protein isoelectric point of 5.5. In order to recover the precipitated MP, the solution was transferred to centrifuge bottles and spun at $10,000 \times \mathrm{G}$ for $15 \mathrm{~min}$ at $4^{\circ} \mathrm{C}$. After discarding the supernatant containing process water, the protein fraction that had formed a pellet was collected. Protein paste was developed immediately after the protein was weighed.

\subsection{Development of Protein Paste}

A universal food processor (model UMC5, Stephan Machinery Corp., Columbus, OH) was used to chop the collected MP $(800 \mathrm{~g})$. The initial moisture of the recovered myofibrillar protein was $840 \mathrm{~g} / \mathrm{kg}$, measured using a moisture analyzer moisture analyzer (Ohaus Model MB45, Nänikon, Switzerland). MP was chopped at low speed for 1 min and then salt $(20 \mathrm{~g} / \mathrm{kg})$ was added ${ }^{4,18}$. Following mixing for $1 \mathrm{~min}$, chilled $\left(4^{\circ} \mathrm{C}\right)$ distilled/deionized water, and standard functional additives including potato starch $(0$, or $15 \mathrm{~g} / \mathrm{kg}$ ) (Penbind 1000 modified potato starch, Penford Food Ingredients Corp., Centennial, CO), polyphosphates ( 0 or $3 \mathrm{~g} / \mathrm{kg}$ ) (Kena FP-28, Innophos, Cranbury, NJ), transglutaminase (TGase) $(0$ or $5 \mathrm{~g} / \mathrm{kg})$, and SP powder $(0,5$, or $23 \mathrm{~g} / \mathrm{kg}$ ) were added. The final moisture of the mixture was adjusted to $800 \mathrm{~g} / \mathrm{kg}$ and the total amount of additives were set at $23 \mathrm{~g} / 100 \mathrm{~g}$ for all tested formulations. The paste was mixed for 1 min to ensure even distribution of additives. Temperature of chopper was kept at $1-4{ }^{\circ} \mathrm{C}$ throughout the process to avoid thermal denaturation of proteins. After confirming the $\mathrm{pH}$ of the paste as 7.0-7.2, the paste was mixed for 3 min at high speed under vacuum $(50 \mathrm{kPa})$. The final paste was vacuum packaged to avoid air bubble formation which would interfere with the 
textural properties upon cooking. Protein paste $(5 \mathrm{~g})$ was separately weighed and placed in a steel container on ice for differential scanning calorimetry testing right after vacuum packaging. The rest of the paste in the vacuum package was placed in a gel presser. The paste was then stuffed into lightly oil sprayed stainless steel tubes $($ length $=17.5 \mathrm{~cm}$, inner diameter $=1.9 \mathrm{~cm})$ and dumbbell shaped stainless steel torsion tubes $($ length $=17.5 \mathrm{~cm}$, end diameter $=1.9 \mathrm{~cm}$, midsection diameter $=1.0 \mathrm{~cm}$ ) to ensure flawless gel formation after cooking.

\subsection{Differential Scanning Calorimetry (DSC) Analysis}

DSC measures the thermodynamic properties of molecules including the unfolding temperatures of proteins and the energy required to illicit these phase transitions ${ }^{27}$. Therefore, the functional properties (temperature onset (Tonset), maximum temperature (Tmax), and enthalpy) of the protein paste samples were measured using DSC (DSC Infinity Series F5010, Instrument Specialists, Inc., Spring Grove, IL) ${ }^{17}$. Samples were prepared by placing freshly developed protein paste (10-15 $\mu \mathrm{g}$ ) onto aluminum pans (Instrument Specialists Inc., $4 \mathrm{~mm})$. The pans were then hermetically sealed and placed in the scanner. Reference sample was an empty, hermetically sealed aluminum pan. The temperature in the scanner increased from $5{ }^{\circ} \mathrm{C}$ to $90^{\circ} \mathrm{C}$ at a rate of $10{ }^{\circ} \mathrm{C} / \mathrm{min}$. Each protein paste formulation was tested 4 times and the data was presented as mean \pm standard deviation. Infinite Software (Instrument Specialists Inc., Twin Lakes, WI, USA) was used to analyze Tonset, Tmax, and the enthalpies. Thermograms representing the protein unfolding curves were drawn in excel from the data points collected from the analysis.

\subsection{Myofibrillar Gel Preparation}

Steel tubes containing protein pastes were stored at $4^{\circ} \mathrm{C}$ for $24 \mathrm{~h}$ before cooking to allow

for gel network formation ${ }^{4,18}$. Following cooking at $90{ }^{\circ} \mathrm{C}$ for $20 \mathrm{~min}$ in a water bath (Precision, 
Jouan Inc, Wincester, Virginia) and chilling on ice for $15 \mathrm{~min}$, the tubes were kept at room temperature (approximately $23^{\circ} \mathrm{C}$ ) for $1 \mathrm{~h}$. Upon cooling, the gels were taken out of the tubes, cut and texture and color properties were analyzed.

\subsection{Texture Profile Analysis (TPA)}

Texture profile analysis is a widely used analysis to determine the textural properties (hardness, springiness, cohesiveness, gumminess, chewiness and resilience) of solid food substances by using a compression plate attachment that presses food samples twice mimicking biting ${ }^{29}$. Therefore, 8 cylindrical gel samples (length $2.54 \mathrm{~cm}$, diameter $1.9 \mathrm{~cm}$ ) from each formula tested were analyzed using a texture analyzer (Model TA-HDi, Texture Technologies Corp., Scarsdale, NY) with a $70 \mathrm{~mm}$ compression plate ${ }^{4,18}$. Hardness, springiness, cohesiveness, gumminess, chewiness and resilience values were calculated by Texture Expert software (Texture Expert Exceed version 2.64, Stable Micro Systems, 2003) and was presented as mean \pm standard deviation.

\subsection{Kramer Shear Cell Test}

Kramer shear cell test is another method for measuring gel strength. Similar to the TPA, a texture analyzer (Model TA-HDi, Texture Technologies Corp., Scarsdale, NY) is used with a Kramer cell attachment with five blades ( $3 \mathrm{~mm}$ thick and $70 \mathrm{~mm}$ wide). This method evaluates the force required to cut the gel sample similar to that of cutting a food sample with a knife. The peak force (g/g sample) in this study was measured at $127 \mathrm{~mm} \mathrm{~min}^{-1}$ crosshead speed using Texture Expert software (Texture Expert Exceed version 2.64, Stable Micro Systems, 2003) ${ }^{4,18}$. At least 6 cylindrical gel samples (length $8 \mathrm{~cm}$, diameter $1.9 \mathrm{~cm}$ ) were analyzed for each formula. The shear force was calculated by dividing peak force by the initial weight of the sample. Shear stress, showing gel cohesiveness and firmness was calculated by a ratio of the 
force with the area of the sample provided by the Texture Expert software. The results were presented as mean \pm standard deviation.

\subsection{Torsion Analysis}

The protein gels that were molded in the dumbbell shaped steel tubes were cut into 2.54 $\mathrm{cm}$ long cylinders after removal from the tubes. Top and bottom ends of the samples were glued to plastic discs, set at room temperature for 20 min and then placed in a Hamman torsion meter (Gel Consultants, Raleigh, NC, USA). The samples were twisted at $2.5 \mathrm{rpm}$ until they broke at fracture in the mid-section. Shear stress and strain were calculated using Torsion Vane (Gel Consultants, Raleigh, NC, USA) from torque and angular displacement data ${ }^{17}$. At least 12 samples were tested for each formula and the results were presented as mean \pm standard deviation.

\subsection{Color analysis}

Color is another important aspect determining the marketability of a food product. Although color can be manipulated using food grade additives such as titanium dioxide, a widely used whitener, naturally whiter gels are preferable due to cost and demand for no-additive products. Moreover, color properties such as L* (lightness; scale: 0 - 100), a* (intensity in red color; scale: $-60-+60$ ), and b* (intensity in yellow color; scale: $-60-+60$ ) indicate the removal or presence of impurities such as hemoglobin and connective tissues. Therefore, at least 15 cylindrical gel samples (length $2.54 \mathrm{~cm}$, diameter $1.9 \mathrm{~cm}$ ) were tested for each protein gel formula using a colorimeter (Minolta Camera Co. Ltd, Osaka, Japan) that was calibrated with a standard white plate No.21333180 (CIE L* 93.1; $\left.a^{*} 0.3135 ; b^{*} 0.3198\right)^{4,18}$. The following equation was used to calculate whiteness ${ }^{4}$ :

$$
\text { Whiteness }=100-\left[(100-L)^{2}+a^{2}+b^{2}\right]^{1 / 2}
$$




\subsection{Statistical Analysis}

All trials were randomized prior to this research. Statistical analysis was performed using JMP software (JMP 10.2, SAS Inst., Cary, NC, USA). Analysis of variance (ANOVA) was applied at a significance level of 0.05 . The data points were replicated as indicated under each section and the results were presented as mean \pm standard deviation. Tukey's Honestly Significant Differences (HSD) test showing differences between starch (15g/protein paste) and polyphosphate $\left(3 \mathrm{~g} / \mathrm{kg}\right.$ protein paste) containing formulae is indicated by letters ${ }^{\mathrm{a}, \mathrm{b}, \mathrm{c}}$. Another statistical analysis was performed to compare values obtained from different gel formulations and different letters $\left({ }^{\mathrm{w}, \mathrm{x}, \mathrm{y}, \mathrm{z}}\right)$ were assigned to show significant (Tukey's HSD, $\left.\mathrm{p}<0.05\right)$ differences between all tested formulae. Moreover, formulae not containing any starch or polyphosphates are compared with each other and the differences are indicated in bold (Tukey's honestly significant differences test, $\mathrm{p}<0.05)$.

\section{Results and Discussion}

\subsection{Thermal Changes}

The thermal denaturation curves of protein groups in the myofibrillar protein gels and the thermostatic properties of protein unfolding and aggregation are provided in Figure 1 and Table 1, respectively. Myosin and actin are the major protein groups in myofibrillar protein and are responsible for gelation ${ }^{29}$. Myosin consists of a globular head region that is more susceptible than the tail to thermal denaturation because it contains the sites for ATP hydrolysis and fibrillar actin binding ${ }^{30}$. Gelation occurs as myosin and actin bind together and entrap the gel

constituents ${ }^{31}$; therefore, it is important to determine the differences in thermal stability of these molecules as impacted by different formulae and processing strategies. 
Peak I shows that the thermal changes in myosin head did not differ ( $p>0.05$ ) between strategies containing $23 \mathrm{~g} \mathrm{SP} / \mathrm{kg}$ paste and no additives. Myosin, with its high gelation properties was able form a gel without functional additives. Furthermore, incorporating $23 \mathrm{~g} \mathrm{SP} / \mathrm{kg}$ paste did not affect myosin unfolding adversely. For the most part, gels containing $23 \mathrm{~g} \mathrm{SP} / \mathrm{kg}$ paste required more energy for conformational changes as indicated by the enthalpies for myosin tail (Peak II), actin (Peak III) and sarcoplasmic protein (Peak IV) compared to all other gels $(\mathrm{p}<0.05)$. It was previously reported that the thermal stability of gels with added SP is reduced when salt concentrations in the protein pastes are high and are improved when salt concentrations are low, possibly due to increased binding of sarcoplasmic protein and myosin at lower salt concentrations ${ }^{31,33}$. Another study where $20 \mathrm{~g}$ salt $/ \mathrm{kg}$ was added to protein paste, which is the same amount incorporated into MP in this study, reported significant reduction in thermal stability ${ }^{33}$. In correlation with that, porcine SP was shown to have high fat binding characteristics as well as thermal stability without added salt ${ }^{34}$. This is why MP gels containing salt and no other additives yielded comparable, or even higher (enthalpy of form actin denaturation (Peak 3)) results than gels containing functional additives such as potato starch, and polyphosphates for resistance to thermal change. Although salt increases MP solubility by enabling actin myosin cross-linking, gels containing SP will benefit from low salt content. This is also shown in a similarly designed study where MP recovered using $\mathrm{NaOH}$ were incorporated with $\mathrm{SP}^{35}$. Myosin, and SP denaturation peaks indicated that these protein groups were more thermo-stable when only salt containing MP gels were more resistant compared to gels containing $23 \mathrm{~g} \mathrm{SP} / \mathrm{kg}$ paste ${ }^{35}$. This can be attributed to the suppressed SP activity at high salt conditions. 
When TGase was replaced with $5 \mathrm{~g} \mathrm{SP} / \mathrm{kg}$ paste MP functionality was maintained (Table 1). Especially myosin head and actin, as indicated by Peak I and III, was more resistant $(\mathrm{p}<0.05)$ to thermal degradation when $5 \mathrm{~g} \mathrm{SP} / \mathrm{kg}$ paste was added by increasing the heat energy necessary to unfold the protein groups. Samples with $5 \mathrm{~g} \mathrm{SP} / \mathrm{kg}$ paste required more $(\mathrm{p}<0.05)$ energy to unfold SP in the MP gels, compared the TGase gels made with MP recovered using $\mathrm{NaOH}$. On the other hand, gels made out of MP processed with $\mathrm{Ca}(\mathrm{OH})_{2}$ were more $(\mathrm{p}<0.05)$ thermoresistant than $\mathrm{NaOH}$ gels for SP peak (Peak IV). This is likely because decreased salt content increases thermal stability of SP; however, $5 \mathrm{~g} \mathrm{SP} / \mathrm{kg}$ paste may be too little to observe significant effects. This is consistent with the enthalpy results of where energy required to unfold all discussed protein groups (myosin, actin, and sarcoplasmic protein) is higher $(\mathrm{p}<0.05)$ for gels made with $23 \mathrm{~g} \mathrm{SP} / \mathrm{kg}$ protein paste compared to gels containing TGase. A study reported that gel strength was significantly increased and resistance to deformation was not influenced when SP was added to MP gels which was attributed to increased thermal stability by $\mathrm{SP}^{33}$. Therefore, higher amounts of SP ( $>20 \mathrm{~g} / \mathrm{kg}$ paste) with low amount salt ( $<20 \mathrm{~g} / \mathrm{kg}$ protein paste) may improve functionality of protein groups responsible for gel formation during thermal processes.

As expected, using different processing bases during ISP for MP recovery resulted in gels with different thermal denaturation peaks. When TGase gels made with either $\mathrm{NaOH}$ or $\mathrm{Ca}(\mathrm{OH})_{2}$ processed MP are compared, MP recovered using $\mathrm{NaOH}$ formed gels requiring more $(\mathrm{p}<0.05)$ energy for myosin head denaturation; whereas, gels made with calcium enhanced protein showed increased $(\mathrm{p}<0.05)$ actin and SP resistance to thermal processing. This may be explained by the previously mentioned effect of salt content ${ }^{31}$. $\mathrm{NaOH}$ processing resulted in MP with high amounts of sodium compared to $\mathrm{Ca}(\mathrm{OH})_{2}$ processing which resulted in MP with high amounts of calcium. Endogenous TGase which is abundant in fish muscle is a calcium dependent enzyme; 
therefore, using calcium enhanced protein may result in more cohesive gels due to increased endogenous TGase activity ${ }^{36}$. It is also interesting to see that MP gels containing $5 \mathrm{~g} \mathrm{SP} / \mathrm{kg}$ paste which are made from $\mathrm{Ca}(\mathrm{OH})_{2}$ recovered protein showed similarly high functionality with $\mathrm{NaOH}$ processed gels containing TGase in myosin head thermo-stability which may be associated with the increased endogenous TGase activity due to higher calcium content. Similar results were observed when SP recovered from tilapia was added to actomyosin, the complex formed during gelation due to the linking of actin with myosin ${ }^{37}$. In the same study, it was seen that SP isolated from tilapia triggered myosin heavy chain making up the myosin head and troponin crosslinking; however, actin and tropomyosin were not influenced by SP addition ${ }^{36}$. These observations similar to the ones reported in this study are possibly due to the proteolytic activity inhibition properties of $\mathrm{SP}^{37}$.

\subsection{Textural Properties}

Texture profile analysis data is shown in Table 2. Comparison between gels containing functional additives such as starch and polyphosphates revealed that MP gels were harder, gummier and chewier $(\mathrm{p}<0.05)$ when TGase was added to MP recovered using $\mathrm{Ca}(\mathrm{OH})_{2}$. On the other hand, resilience, which is the resistance to deformation when a force presses down the sample, benefited $(\mathrm{p}<0.05)$ from $5 \mathrm{~g} \mathrm{SP} / \mathrm{kg}$ paste addition. This is confirmed with the torsional shear strain results presented in Figure 2, where shear strain, which reflects resistance to deformation at the axial deformation point, was higher $(\mathrm{p}<0.05)$ in gels containing $5 \mathrm{~g} \mathrm{SP} / \mathrm{kg}$ paste. Since resilience and torsional shear strain results are the same for the two TGase containing gel formulae, the improved $(\mathrm{p}<0.05)$ values displayed by $5 \mathrm{~g} \mathrm{SP} / \mathrm{kg}$ paste addition is attributed to the protease inhibitory activity of SP. Similar observations were noted in a study 
where $10 \mathrm{~g} \mathrm{SP} / \mathrm{kg}$ paste recovered from lizardfish was added to MP gels and breaking force and resistance to deformation was increased ${ }^{37}$.

Using different processing bases during MP solubilization had an effect on textural properties as they did on functional properties. Protein recovery with $\mathrm{Ca}(\mathrm{OH})_{2}$ resulted in harder, gummier, chewier and stronger $(\mathrm{p}<0.05)$ gels indicated by TPA results and Kramer shear force (Table 2, Figure 2). MP recovered using $\mathrm{Ca}(\mathrm{OH})_{2}$ had more $(\mathrm{p}<0.05)$ protein $(850 \mathrm{~g} / \mathrm{kg})$ in the recovered protein fraction compared to MP solubilized at the same $\mathrm{pH}$ using $\mathrm{NaOH}(700 \mathrm{~g} / \mathrm{kg})^{23}$. As previously explained, this may be due to the increased protein solubilization properties associated with $\mathrm{Ca}(\mathrm{OH})_{2}$ when used as a processing base during $\mathrm{pH}$ shifts ${ }^{23}$. On the other hand, when MP was solubilized with $\mathrm{NaOH}$ torsional shear stress and cohesiveness were greater $(\mathrm{p}<0.05)$ indicating a more uniform gel network formation (Table 2, Figure 2). This may be explained by the higher sodium content of the MP used to make the gels. Improvement in myosin cross-linking due to the greater glutamine and lysine residue availability was reported at high salt concentrations for TGase added MP gels ${ }^{34}$. Therefore, a stronger gel network may be formed with the increased glutamine and lysine isopeptide bonds ${ }^{38}$.

Addition of $23 \mathrm{~g} \mathrm{SP} / \mathrm{kg}$ paste with no other functional additives resulted in harder, gummier, and chewier $(\mathrm{p}<0.05)$ gels compared to MP gels containing $5 \mathrm{~g} \mathrm{SP} / \mathrm{kg}$ paste with $15 \mathrm{~g}$ starch/kg paste and $3 \mathrm{~g} \mathrm{PP} / \mathrm{kg}$ paste. This formula also yielded gels with similar texture (hardness gumminess, and chewiness) as gels containing TGase made with calcium enhanced MP. Previous studies using $10 \mathrm{~g} \mathrm{SP} / \mathrm{kg}$ paste recovered from lizardfish, and 20g SP/kg paste from rockfish incorporated into MP gels displayed improved gel texture and resistance to deformation ${ }^{33,37}$. Therefore, increasing the amount of SP added and using both functional additives and SP in MP gels may show higher textural properties. 


\subsection{Color}

Color of the MP gels made with using different functional additives are presented in Table 2, and the whiteness values are shown in Figure 3. Lightness, as indicated by $\mathrm{L}^{*}$, was highest $(\mathrm{p}<0.05)$ in MP solubilized using $\mathrm{Ca}(\mathrm{OH})_{2}$ and formulated with TGase while the gels with the same formulation made from MP recovered using $\mathrm{NaOH}$ were the darkest $(\mathrm{p}<0.05)$. When $\mathrm{Ca}(\mathrm{OH})_{2}$ was used as the processing base protein gels were whiter $(\mathrm{p}<0.05)$, regardless of formulation, and therefore may reduce the need for adding the widely used titanium dioxide.

Redness $\left(\mathrm{a}^{*}\right)$, which associated with blood residue, was highest $(\mathrm{p}<0.05)$ in gel samples made with no functional additives. Moreover, when the processing bases during MP recovery are compared, $\mathrm{Ca}(\mathrm{OH})_{2}$ yielded gels are less red $(\mathrm{p}<0.05)$. Similarly, yellowness $\left(\mathrm{b}^{*}\right)$, which is linked to connective tissue and heme protein content, was lower $(\mathrm{p}<0.05)$ when $\mathrm{Ca}(\mathrm{OH})_{2}$ was used during $\mathrm{pH}$ shifts. Furthermore, addition of as low as $5 \mathrm{~g} \mathrm{SP} / \mathrm{kg}$ paste increased yellowness, which is consistent with other studies ${ }^{33}$. This is most likely due to heme proteins associated with SP. It is interesting to note that both gels that did not contain starch were less yellow $(\mathrm{p}<0.05)$ than the SP gel with starch which is attributed to the visibly yellow color of potato starch.

Gels containing SP were darker $(\mathrm{p}<0.05)$ than the TGase gels made with MP solubilized using $\mathrm{CaOH} 2$. SP includes albumins, globulins, and enzymes, and the concentration of each depends on the fish species it is extracted from and will likely impact color. There was no difference ( $p>0.05$ ) between gels with $23 \mathrm{~g} \mathrm{SP} / \mathrm{kg}$ and the gels containing no functional additives. Yet, $23 \mathrm{~g} \mathrm{SP} / \mathrm{kg}$ paste containing gels were whiter $(\mathrm{p}<0.05)$ than gels formulated with $5 \mathrm{~g} \mathrm{SP} / \mathrm{kg}$ paste; therefore, the decreased whiteness was possibly influenced by potato starch rather than SP addition as previously discussed. Moreover, using $\mathrm{Ca}(\mathrm{OH})_{2}$ during protein 
recovery resulted in whiter $(\mathrm{p}<0.05)$ gels also indicated by lightness $\left(\mathrm{L}^{*}\right)$ due to the increased calcium content in the recovered MP.

\section{Conclusions}

Overall, improved myosin-actin complex formation leading to a more cohesive gel network and stronger gels may either be obtained by the combination of high salt concentration and microbial TGase addition or lower amount of sodium containing MP with high amounts (>23 g/kg paste) of SP addition. In addition to the salt content, using calcium enhanced MP as a result of $\mathrm{Ca}(\mathrm{OH})_{2}$ application during recovery may contribute to increased gel strength. Since fish muscle protein contains a high amount of calcium dependent endogenous TGase, using calcium enhanced protein may catalyze protein-protein interactions without the need for adding microbial TGase. Additionally, protein recovery using $\mathrm{Ca}(\mathrm{OH})_{2}$ will yield harder, springier, gummier, chewier, firmer, and whiter gels compared to $\mathrm{NaOH}$ processing due to calcium enhancement.

\section{Abbreviations}

MP: Myofibrillar protein

SP: Sarcoplasmic protein

LA: Lactic acid

$\mathrm{NaOH}$ : Sodium hydroxide

TGase: Transglutaminase

DSC: Differential scanning calorimetry

TPA: Texture profile analysis 
PP: Polyphosphates

6. Acknowledgements

This work was funded by the HATCH Program Project \# (WVA 00622). 


\section{References}

1. Careche, M.; Alvarez, C.; Tejada, M. Suwari and kamaboko sardine gels. Effect of heat treatment on solubility of networks. J. Agr. Food Chem. 1995, 43, 1002-1010.

2. Morrissey, M.T.; Wu, J.W.; Lin, D.; An, H. Protease inhibitor effects on torsion measurements and autolysis of Pacific whiting surimi. J. Food Sci. 1993, 58, 1054-1059.

3. Chang-Lee, M. V.; Lampila, L. E.; Crawford, D. L. Yield and composition of surimi from pacific whiting (Merluccius productus) and the effect of various protein additives on gel strength. J Food Sci. 1990, 55, 83-86.

4. Taskaya, L.; Chen, Y. C.; Beamer, S.; Jaczynski, J. Texture and colour properties of proteins recovered from whole gutted silver carp (Hypophthalmichthys molitrix) using isoelectric solubilization/ precipitation. J. Sci. Food Agr. 2009, 89, 349-358.

5. Gehring, C.K.; Gigliotti, J. C.; Moritz, J. S.; Tou, J. C.; Jaczynski, J. Functional and nutritional characteristics of proteins and lipids recovered by isoelectric processing of fish by-products and low-value fish: A review. Food Chem. 2011, 124, 422-431.

6. Park, J. W.; Morrissey, M. T. Manufacturing of surimi from light muscle fish. In Surimi and Surimi Seafood; Park, J. W., Ed.: Marcel Dekker, New York, NY, USA, 2000: pp. 23-58.

7. Miyaguchi, Y.; Nagayama, K.; Tsutsumi, M. Thermal and functional properties of porcine sarcoplasmic proteins: a comparison with some watersoluble animal proteins. Jpn. Soc. Animal Sci. 2000, 71(4), 416-424.

8. Shimizu, Y.; Nishioka, F. Interactions between horse mackerel actomyosin and sarcoplasmic proteins during heat coagulation. B. Jpn. Soc. Sci. Fish. 1974, 40, 231-234.

9. Siriangkanakun, S.; Yongsawatdigul, J. Trypsin inhibitory activity and gel-enhancing effect of sarcoplasmic proteins from common carp. J. Food Sci. 2012, 77, C1124-1130.

10. Morioka, K.; Shimizu, Y. Contribution of sarcoplasmic proteins to gel formation of fish meat. Nippon Suisan Gakk. 1990, 56, 929-933.

11. Ko, W. C.; Hwang, M. S. Contribution of milkfish sarcoplasmic protein to thermal gelation of myofibrillar protein. Fish Sci. 1995, 61, 75-78.

12. Nowsad, A. A.; Katoh, S.; Kanoh, S.; Niwa, E. Effect of sarcoplasmic protein on the transglutaminase-free paste. Fish Sci. 1995, 61, 1039-1040. 
13. Park, J. W.; Morrissey, M. T. Manufacturing of surimi from light muscle fish. In Surimi and Surimi Seafood; Park, J. W., Ed.: Marcel Dekker, New York, NY, USA, 2000: pp. 23-58.

14. Lin, T. M.; Park, J. W.; Morrissey, M. T. Recovered protein and reconditioned water from surimi processing waste. J. Food Sci. 1995, 60, 4-9.

15. Paker, I.; Matak, K. E. Impact of sarcoplasmic protein recovered from fish processing wash water on texture of protein gels. LWT-Food Sci. Technol. In review.

16. Paker, I.; Beamer, S.; Jaczynski, J.; Matak, K. E. Compositional characteristics of materials recovered from headed gutted silver carp (Hypophthalmichthys molitrix) by isoelectric solubilization and precipitation using organic acids. J. Food Sci. 2013, 78, E445-E451.

17. Paker, I.; Beamer, S.; Jaczynski, J.; Matak, K. E. The effect of organic acids on gelation characteristics of protein gels made from silver carp (Hypophthalmichthys molitrix) protein recovered by isoelectric solubilization and precipitation. LWT - Food Sci. Technol. 2013, 53, 3743.

18. Paker, I.; Beamer, S.; Jaczynski, J.; Matak, K. E. pH shift protein recovery with organic acids on texture and color of cooked gels. J Sci. Food Agr. 2015, 95, 275-280.

19. Otto, R.A.; Beamer, S.; Jaczynski, J.; Matak, K.E. The effect of using citric or acetic acid on survival of Listeria monocytogenes during fish protein recovery by isoelectric solubilization and precipitation process. J. Food Sci. 2011, 76, M579-583.

20. Otto, R.A.; Paker, I.; Bane, L.; Beamer, S.; Jaczynski, J.; Matak, K. E. 2011b. Survival of Listeria inoccua in rainbow trout protein recovered by isoelectric solubilization and precipitation with acetic and citric acids. J. Food Prot. 2011, 74, 1348-1352.

21. Lansdowne, L.R.; Beamer, S.; Jaczynski, J.; Matak, K. E. Survival of Escherichia coli after isoelectric solubilization and precipitation of fish protein. J. Food Prot. 2009, 7, 1398-1403.

22. Lansdowne, L.R.; Beamer, S.; Jaczynski, J.; Matak, K. E. Survival of Listeria innocua after isoelectric solubilization and precipitation of fish protein. J. Food Sci. 2009, 74, M201-M205. 23. Paker, I. Calcium Hydroxide as a Potential Base in Alkali Aided pH Shift Process. In Calcium enhanced protein recovery from underutilized aquatic resources and optimizing protein 
gelation strategies using functional ingredients, $\mathrm{PhD}$ Dissertation submitted to Animal and Nutritional Sciences Department at West Virginia University, 2015.

24. Paker, I. Calcium Enhanced Protein Recovery from Black Bullhead Catfish Using Organic Acids. In Calcium enhanced protein recovery from underutilized aquatic resources and optimizing protein gelation strategies using functional ingredients, PhD Dissertation submitted to Animal and Nutritional Sciences Department at West Virginia University, 2015.

25. Israelachvili, J.N. Contrast between intermolecular, interparticule, and intersurface forces. In Intermolecular and Surface Forces, $2^{\text {nd }}$ ed.; Israelachvili, J.N., Ed.: Academic Press, Inc., London, UK, 1992: pp. 205-223.

26. Hongsprabhas, P. Chapter 1: General Introduction, In Mechanisms of calcium-induced cold gelation of whey protein isolate, $\mathrm{PhD}$ dissertation submitted to Graduate Studies Services of the University of Guelph, 1997: pp.1-5.

27. Spink, C. H. Differential scanning calorimetry. Method. Cell Biol. 2008, 84, 115-141.

28. Andrew, J. R. Texture profile analysis - how important are the parameters? J. Texture Stud. 2010, 41, 672-684.

29. Sun, X.D.; Holley, R.A. Factors influencing gel formation by myofibrillar proteins in muscle foods. Compr Rev Food Sci. F., 2011, 10, 33-51.

30. Takahashi, M.; Yamamoto, T.; Kato, S.; Konno, K. Species-specific thermal denaturation pattern of fish myosin when heated as myofibrils as studied by myosin subfragment-1 and rod denaturation rates. Fish. Sci. 2005, 71, 405-413.

31. Jafarpour, A.; Gorczyca, E. M. Contribution of sarcoplasmic proteins to myofibrillar proteins gelation. J. Food Sci. 2012, 77, R73-R81.

32. Macfarlane, J. J.; Schmidt, G. R.; Turner, R. H. Binding of meat pieces: a comparison of myosin, actomyosin and sarcoplasmic proteins as binding agents. J. Food Sci. 1977, 42, 16031605.

33. Young, K. S.; Yongsawatdigul, J.; Park, J. W.; Thawornchinsombut, S. Characteristics of sarcoplasmic proteins and their interaction with myofibrillar proteins. J. Food Biochem. 2005, 29, 517-532. 
34. Miyaguchi, Y.; Hayashi, Y.; Nagayama, K. Improvement of the emulsifying properties of porcine sarcoplasmic proteins with a low-molecular weight surfactant by the two step emulsification method. Animal Sci. J. 2003, 74, 145-151.

35. Paker, I. The Effect of Sarcoplasmic Protein Powder as an Additive in Myofibrillar Protein Gels Recovered by pH-Shift Process Using Lactic Acid. In Calcium enhanced protein recovery from underutilized aquatic resources and optimizing protein gelation strategies using functional ingredients, PhD Dissertation submitted to Animal and Nutritional Sciences Department at West Virginia University, 2015.

36. Kuraishi C, Yamazaki K and Susa Y, Transglutaminase: its utilization in the food industry. Food Rev. Int. 17(2): 221-246 (2001).

37. Yongsawatdigul, J.; Piyadhammaviboon, P. Gel-enhancing effect and protein crosslinking ability of tilapia sarcoplasmic proteins. J. Sci. Food Agric. 2007, 87, 2810-2816.

38. Chen, J.; Xiong, Y. L.; Li, C. Oxidation-induced unfolding facilitates myosin cross-linking in myofibrillar protein by microbial transglutaminase. J. Agric. Food Chem. 2012, 60, 8020-8027. 


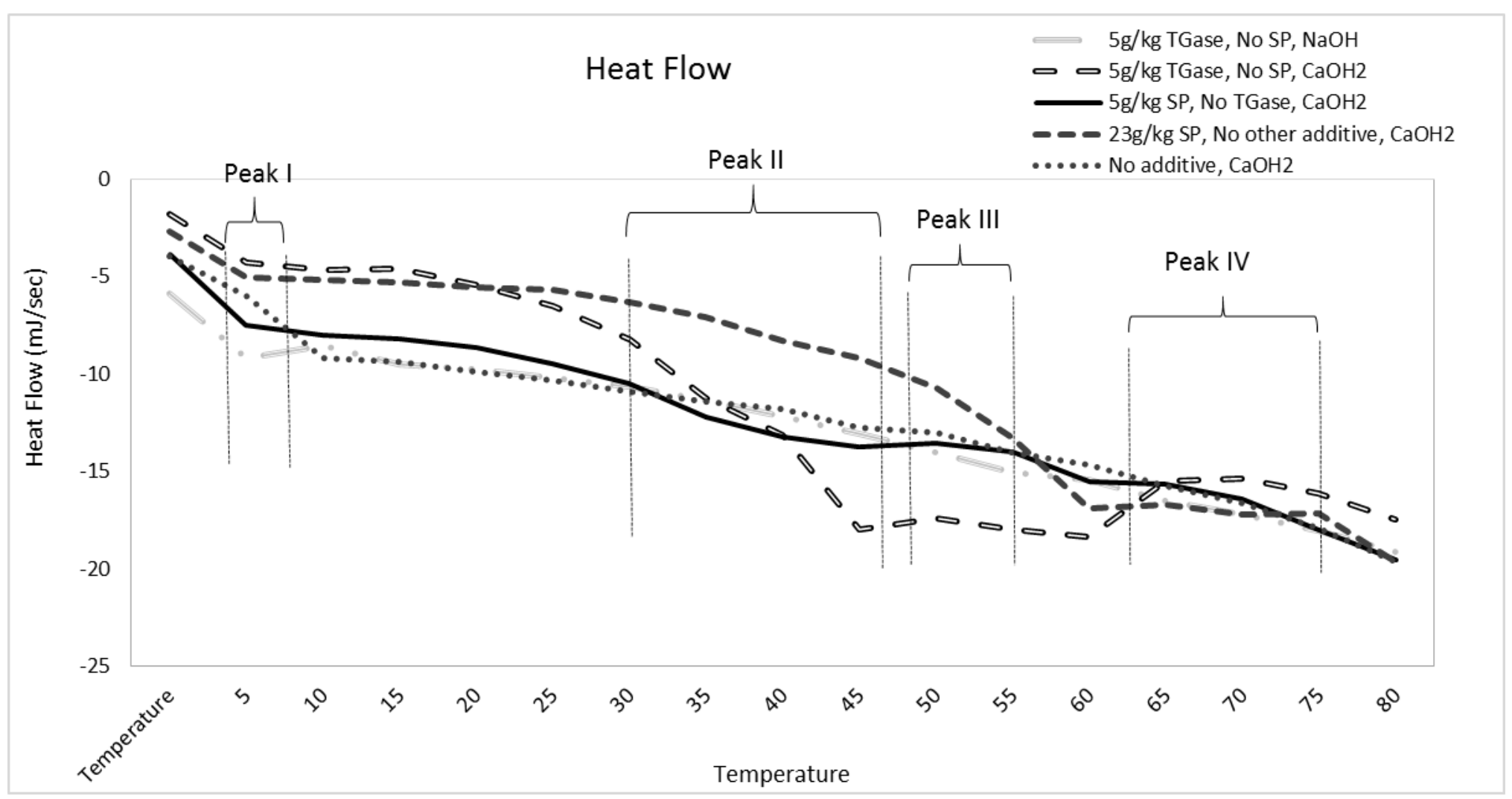

Figure 1. Differential scanning calorimetry (DSC) thermograms of black bullhead catfish protein pastes developed using different additives. Each curve was drawn using the mean of data points collected from 4 individual replications per formulation. 


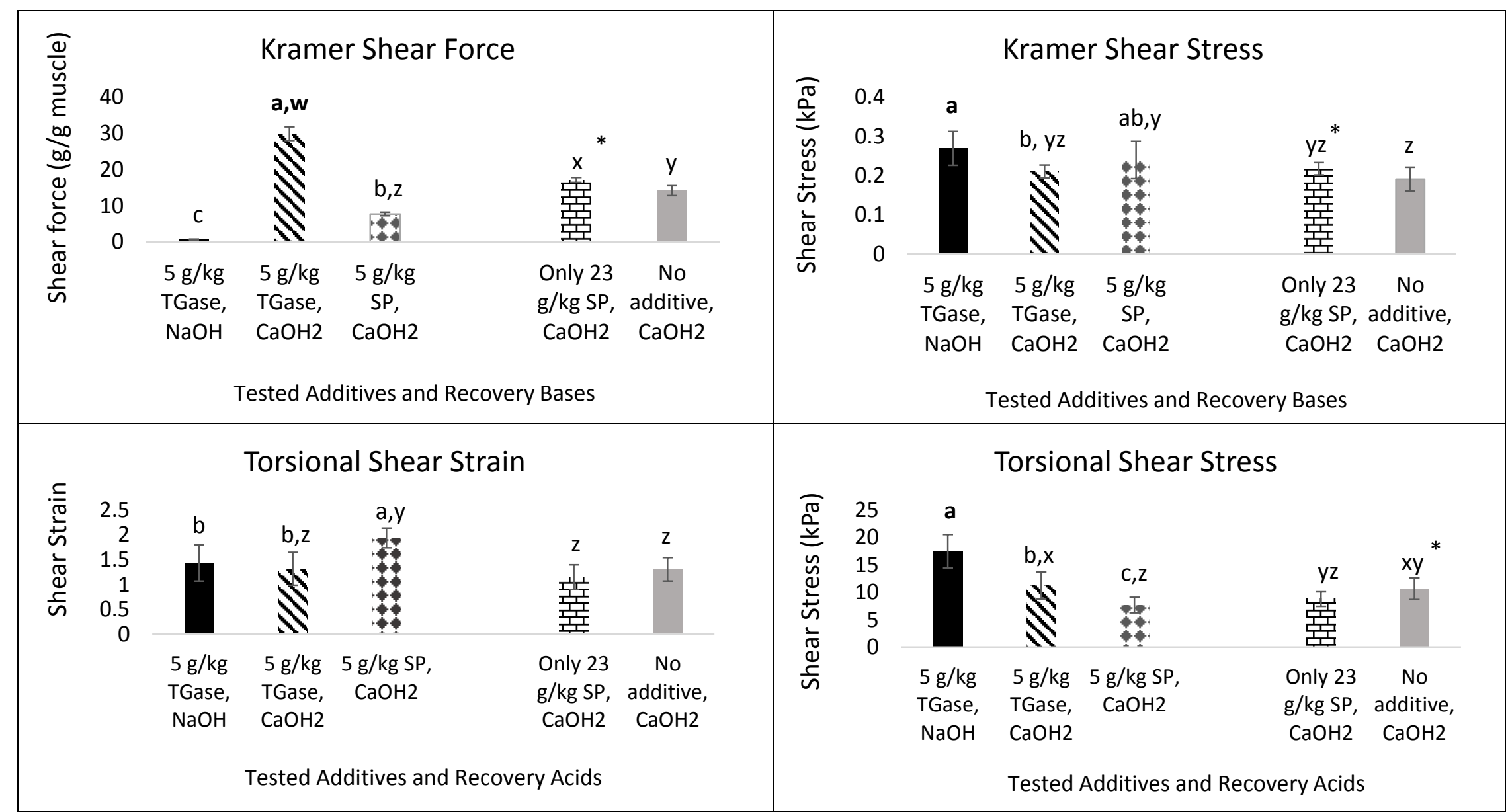

Figure 2. Kramer shear stress $(\mathrm{kPa})$, Kramer shear force $(\mathrm{g} / \mathrm{g}$ muscle), torsional shear stress $(\mathrm{kPa})$ and torsional shear strain of recovered black bullhead catfish protein gels. Data are given as mean \pm standard deviation.

a,b,c indicate significant differences between mean values of gels containing $5 \mathrm{~g}$ TGase/kg paste and $5 \mathrm{~g}$ SP/kg protein paste (Tukey’s honestly significant differences (HSD) test, $\mathrm{p}<0.05)$. ${ }^{\mathrm{x}, \mathrm{y}, \mathrm{z}}$ Mean values with different letters in a column are significantly different (Tukey's HSD, $\mathrm{p}<0.05)$. * indicate significant $(\mathrm{p}<0.05)$ differences between gels made using no functional additives ( starch, and polyphosphates $(\mathrm{PP})$ ). Bold values indicate significant $(\mathrm{p}<0.05)$ differences between gels developed from MP recovered using either $\mathrm{NaOH}$ or $\mathrm{Ca}(\mathrm{OH})_{2}$ processed MP with $5 \mathrm{TGase} / \mathrm{kg}$ protein paste. 
Table 1. Differential scanning calorimetry (DSC) measurements (temperature onset (Tonset), maximum temperature (Tmax), and net enthalpy) of isoelectrically recovered black bullhead catfish protein pastes developed using different additives. Peak I and II represent the heat flow required to unfold myosin head and tail respectively. Peak III and IV represent the heat flow required to unfold actin and sarcoplasmic protein respectively.

\begin{tabular}{|c|c|c|c|c|c|c|c|c|c|c|}
\hline \multicolumn{11}{|c|}{ Tested Formula and MP Solubilization Base } \\
\hline $\begin{array}{l}\text { TGase } \\
\text { (g/kg) }\end{array}$ & $\begin{array}{c}\mathrm{SP} \\
(\mathrm{g} / \mathrm{kg})\end{array}$ & $\begin{array}{l}\text { Starch } \\
(\mathrm{g} / \mathrm{kg})\end{array}$ & $\begin{array}{c}\mathrm{PP} \\
\text { (g/kg) }\end{array}$ & Base & Tonset $\left({ }^{\circ} \mathrm{C}\right)$ & $\operatorname{Tmax}\left({ }^{\circ} \mathrm{C}\right)$ & Enthalpy (J/g) & Tonset $\left({ }^{\circ} \mathrm{C}\right)$ & $\operatorname{Tmax}\left({ }^{\circ} \mathrm{C}\right)$ & Enthalpy $(\mathrm{J} / \mathrm{g})$ \\
\hline 5 & 0 & 15 & 3 & $\mathrm{NaOH}$ & $7.33 \pm 0.16$ & $10.61 \pm 0.14 \mathrm{~b}$ & $2.81 \pm 0.35 a$ & $29.90 \pm 0.44 a$ & $34.59 \pm 0.41$ & $0.27 \pm 0.07 b$ \\
\hline 5 & 0 & 15 & 3 & $\mathrm{CaOH} 2$ & $7.65 \pm 0.28$ & $11.37 \pm 0.36 a$ & $1.47 \pm 0.21 \mathrm{~b}, \mathrm{z}$ & $24.09 \pm 0.64 b, z$ & $30.17 \pm 0.84 z$ & $0.33 \pm 0.07 a b, z$ \\
\hline 0 & 5 & 15 & 3 & $\mathrm{CaOH} 2$ & $7.29 \pm 0.16 \mathrm{yz}$ & $11.25 \pm 0.39 \mathrm{ab}$ & $2.77 \pm 0.24 a, x y$ & $27.82 \pm 1.86 \mathrm{a}, \mathrm{yz}$ & $37.19 \pm 8.00 \mathrm{yz}$ & $0.44 \pm 0.06 a, z$ \\
\hline 0 & 23 & 0 & 0 & $\mathrm{CaOH} 2$ & $5.37 \pm 1.88 \mathrm{z}$ & $9.2 \pm 2.49$ & $3.56 \pm 0.96 x$ & $23.31 \pm 3.30 \mathrm{z}$ & $32.68 \pm 2.81 \mathrm{z}$ & $2.85 \pm 0.57 y$ \\
\hline 0 & 0 & 0 & 0 & $\mathrm{CaOH} 2$ & $6.81 \pm 0.66 \mathrm{yz}$ & $10.95 \pm 0.99$ & $2.09 \pm 0.44 \mathrm{yz}$ & $36.16 \pm 6.03 y$ & $45.18 \pm 3.09 y$ & $0.31 \pm 0.03 z$ \\
\hline \multirow[b]{2}{*}{$\begin{array}{l}\text { TGase } \\
\text { (g/kg) }\end{array}$} & \multirow[b]{2}{*}{$\begin{array}{c}\mathrm{SP} \\
(\mathrm{g} / \mathrm{kg})\end{array}$} & \multirow[b]{2}{*}{$\begin{array}{l}\text { Starch } \\
(\mathrm{g} / \mathrm{kg})\end{array}$} & \multirow[b]{2}{*}{$\begin{array}{c}\mathrm{PP} \\
(\mathrm{g} / \mathrm{kg})\end{array}$} & \multirow[b]{2}{*}{ Base } & \multicolumn{3}{|c|}{ Peak III } & \multicolumn{3}{|c|}{ Peak IV } \\
\hline & & & & & Tonset $\left({ }^{\circ} \mathrm{C}\right)$ & $\operatorname{Tmax}\left({ }^{\circ} \mathrm{C}\right)$ & Enthalpy (J/g) & Tonset $\left({ }^{\circ} \mathrm{C}\right)$ & $\operatorname{Tmax}\left({ }^{\circ} \mathrm{C}\right)$ & Enthalpy $(\mathrm{J} / \mathrm{g})$ \\
\hline 5 & 0 & 15 & 3 & $\mathrm{NaOH}$ & $50.48 \pm 0.40$ & $52.71 \pm 1.42$ b & $0.23 \pm 0.01 \mathrm{c}$ & $68.83 \pm 0.08 a b$ & $74.46 \pm 1.85$ & $0.50 \pm 0.08 \mathrm{c}$ \\
\hline 5 & 0 & 15 & 3 & $\mathrm{CaOH} 2$ & $45.96 \pm 6.16$ & $52.95 \pm 5.53 \mathrm{~b}, \mathrm{z}$ & $0.59 \pm 0.06 b, z$ & $64.65 \pm 1.24 b, z$ & $75.76 \pm 0.41 z$ & $1.57 \pm 0.04 a, y$ \\
\hline 0 & 5 & 15 & 3 & $\mathrm{CaOH} 2$ & $52.42 \pm 4.08$ & $63.96 \pm 6.70 \mathrm{a}, \mathrm{yz}$ & $0.81 \pm 0.03 a, z$ & $73.87 \pm 4.40 \mathrm{a}, \mathrm{y}$ & $77.98 \pm 6.05 y z$ & $1.16 \pm 0.09 b, z$ \\
\hline 0 & 23 & 0 & 0 & $\mathrm{CaOH} 2$ & $45.55 \pm 5.17$ & $57.90 \pm 4.46 \mathrm{yz}$ & $3.07 \pm 0.47 x$ & $70.38 \pm 2.49 y z$ & $77.86 \pm 2.51 \mathrm{yz}$ & $3.38 \pm 0.26 x$ \\
\hline 0 & 0 & 0 & 0 & $\mathrm{CaOH} 2$ & $55.59 \pm 4.50$ & $67.38 \pm 2.40 y$ & $1.59 \pm 0.38 y$ & $74.83 \pm 5.61 \mathrm{y}$ & $83.37 \pm 1.05 \mathrm{z}$ & $0.87 \pm 0.08 z$ \\
\hline
\end{tabular}

Data are given as mean \pm standard deviation. ${ }^{\mathrm{a}, \mathrm{b}, \mathrm{c}}$ Starch and polyphosphate (PP) containing formulae are compared with each other and significant differences between mean values are presented with different letters (Tukey's honestly significant differences test, $\mathrm{p}<0.05)$. The formulae not containing starch and PP are compared with each other and the significant differences ( $\mathrm{p}<0.05)$ are

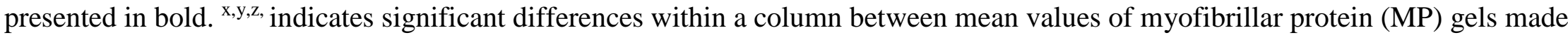
with $\mathrm{Ca}(\mathrm{OH})_{2}$ recovered protein (Tukey's honestly significant differences test, $\mathrm{p}<0.05$ ). Italic and bold values indicate significant $(\mathrm{p}<0.05)$ differences between the $5 \mathrm{~g} / \mathrm{kg}$ TGase containing gels made with either $\mathrm{NaOH}$ or $\mathrm{Ca}(\mathrm{OH})_{2}$ processed $\mathrm{MP}$. 
Table 2. Texture profile (Hardness, Springiness, Cohesiveness, Gumminess, Chewiness, Resilience) of protein gels.

\begin{tabular}{|c|c|c|c|c|c|c|c|c|c|c|}
\hline \multicolumn{5}{|c|}{$\begin{array}{l}\text { Tested Formula and MP Solubilization } \\
\text { Base }\end{array}$} & \multicolumn{6}{|c|}{ Texture Profile Analysis } \\
\hline $\begin{array}{l}\text { Tgase } \\
\text { (g/kg) }\end{array}$ & $\begin{array}{c}\mathrm{SP} \\
(\mathrm{g} / \mathrm{kg})\end{array}$ & $\begin{array}{l}\text { Starch } \\
(\mathrm{g} / \mathrm{kg})\end{array}$ & $\begin{array}{c}P P \\
(g / k g)\end{array}$ & Base & Hardness (g) & $\begin{array}{l}\text { Springiness } \\
(\mathrm{mm})\end{array}$ & $\begin{array}{l}\text { Cohesiveness } \\
\text { (Ratio) }\end{array}$ & Gumminess (g) & Chewiness (g mm) & $\begin{array}{l}\text { Resilience } \\
\text { (Ratio) }\end{array}$ \\
\hline 5 & 0 & 15 & 3 & $\mathrm{NaOH}$ & $11.30 \pm 2.02 \mathrm{c}$ & $1.92 \pm 0.27 \mathrm{~b}$ & $0.55 \pm 0.09 a$ & $4.38 \pm 2.88 \mathrm{c}$ & $13.73 \pm 3.90 \mathrm{c}$ & $0.33 \pm 0.04 \mathrm{~b}$ \\
\hline 5 & 0 & 15 & 3 & $\mathrm{CaOH} 2$ & $308.43 \pm 59.11 a, y$ & $2.26 \pm 0.17 a$ & $0.24 \pm 0.04 b$ & $71.16 \pm 9.76 a, y$ & $162.58 \pm 25.57 a, y$ & $0.37 \pm 0.08 b, z$ \\
\hline 0 & 5 & 15 & 3 & $\mathrm{CaOH} 2$ & $170.93 \pm 28.63 b, z$ & $2.47 \pm 0.45 \mathrm{a}$ & $0.26 \pm 0.08 b$ & $46.22 \pm 12.52 b, z$ & $110.43 \pm 16.94 b, z$ & $0.71 \pm 0.14 a, y$ \\
\hline 0 & 23 & 0 & 0 & $\mathrm{CaOH} 2$ & $272.54 \pm 35.43 y$ & $2.19 \pm 0.17$ & $0.29 \pm 0.04$ & $80.03 \pm 17.34$ y & $166.63 \pm 41.97 y$ & $0.43 \pm 0.08 z$ \\
\hline 0 & 0 & 0 & 0 & $\mathrm{CaOH} 2$ & $188.55 \pm 38.57 \mathrm{z}$ & $2.29 \pm 0.32$ & $0.26 \pm 0.07$ & $44.25 \pm 14.33 z$ & $100.12 \pm 27.25 z$ & $0.40 \pm 0.08 z$ \\
\hline
\end{tabular}

Data are given as mean \pm standard deviation. ${ }^{\mathrm{a}, \mathrm{b}, \mathrm{c}}$ Starch and polyphosphate (PP) containing formulae are compared with each other and significant differences between mean values are presented with different letters (Tukey's honestly significant differences test, $\mathrm{p}<0.05)$. The formulae not containing starch and PP are compared with each other and the significant differences ( $\mathrm{p}<0.05)$ are presented in bold. ${ }^{\mathrm{x}, \mathrm{y}, \mathrm{z},}$ indicates significant differences within a column between mean values of myofibrillar protein (MP) gels made with $\mathrm{Ca}(\mathrm{OH})_{2}$ recovered protein (Tukey's honestly significant differences test, $\mathrm{p}<0.05$ ). Italic and bold values indicate significant $(\mathrm{p}<0.05)$ differences between the $5 \mathrm{~g} / \mathrm{kg}$ TGase containing gels made with either $\mathrm{NaOH}$ or $\mathrm{Ca}(\mathrm{OH})_{2}$ processed MP. 
Table 3. Color and whiteness of protein gels.

Tested Formula and MP Solubilization Base

\begin{tabular}{|c|c|c|c|c|c|c|c|c|}
\hline \multicolumn{6}{|c|}{ I ested rormula and IVIP solubilization Base } & \multicolumn{2}{|l|}{ Color } & \multirow[b]{2}{*}{ Whiteness } \\
\hline $\begin{array}{l}\text { TGase } \\
\text { (g/kg) }\end{array}$ & $\begin{array}{c}\mathrm{SP} \\
(\mathrm{g} / \mathrm{kg})\end{array}$ & $\begin{array}{l}\text { Starch } \\
\text { (g/kg) }\end{array}$ & $\begin{array}{c}P P \\
(\mathrm{~g} / \mathrm{kg})\end{array}$ & Base & $\mathrm{L}^{*}$ & $a^{*}$ & $b^{*}$ & \\
\hline 5 & 0 & 15 & 3 & $\mathrm{NaOH}$ & $48.91 \pm 2.21 \mathrm{c}$ & $2.98 \pm 0.67 a$ & $12.76 \pm 0.74 a$ & $47.24 \pm 2.11 \mathrm{c}$ \\
\hline 5 & 0 & 15 & 3 & $\mathrm{CaOH} 2$ & $67.45 \pm 0.84 a, x$ & $1.12 \pm 0.35 \mathrm{~b}, \mathrm{y}$ & $9.09 \pm 0.29 \mathrm{~b}, \mathrm{y}$ & $66.18 \pm 0.77 a, x$ \\
\hline 0 & 5 & 15 & 3 & $\mathrm{CaOH} 2$ & $59.62 \pm 1.02 \mathrm{~b}, \mathrm{z}$ & $-0.34 \pm 0.13 c, z$ & $12.28 \pm 0.58 a, x$ & $57.79 \pm 0.92 b, z$ \\
\hline 0 & 23 & 0 & 0 & $\mathrm{CaOH} 2$ & $62.03 \pm 1.01$ y & $2.50 \pm 0.94 x$ & $9.51 \pm 0.56$ y & $60.76 \pm 1.03 \mathrm{y}$ \\
\hline 0 & 0 & 0 & 0 & $\mathrm{CaOH} 2$ & $61.53 \pm 1.22 y$ & $4.32 \pm 0.85 w$ & $6.76 \pm 0.99 z$ & $60.73 \pm 1.26 y$ \\
\hline
\end{tabular}

Data are given as mean \pm standard deviation. ${ }^{\mathrm{a}, \mathrm{b}, \mathrm{c}}$ Starch and polyphosphate (PP) containing formulae are compared with each other and significant differences between mean values are presented with different letters (Tukey's honestly significant differences test, $\mathrm{p}<0.05)$. The formulae not containing starch and PP are compared with each other and the significant differences $(\mathrm{p}<0.05)$ are presented in bold. ${ }^{\mathrm{x}, \mathrm{y}, \mathrm{z}}$, indicates significant differences within a column between mean values of myofibrillar protein (MP) gels made with $\mathrm{Ca}(\mathrm{OH})_{2}$ recovered protein (Tukey's honestly significant differences test, $\mathrm{p}<0.05$ ). Italic and bold values indicate significant $(\mathrm{p}<0.05)$ differences between the $5 \mathrm{~g} / \mathrm{kg}$ TGase containing gels made with either $\mathrm{NaOH}$ or $\mathrm{Ca}(\mathrm{OH})_{2}$ processed $\mathrm{MP}$. 


\section{CONCLUSIONS AND INDUSTRY IMPLICATIONS}

Calcium hydroxide $\left(\mathrm{Ca}(\mathrm{OH})_{2}\right)$ may be used as an alternative base during $\mathrm{pH}$ shift processing. Protein solubility and protein concentration was greater with a lower amount of impurities (ash and lipids) retained in the protein fraction when $\mathrm{Ca}(\mathrm{OH})_{2}$ was added during isoelectric solubilization of fish protein compared to sodium hydroxide $(\mathrm{NaOH})$. The highest protein concentration was reached at $92 \%$ when $\mathrm{Ca}(\mathrm{OH})_{2}$ was used to solubilize the protein at $\mathrm{pH} 11.0$ and lactic acid was added to precipitate the protein at the isoelectric point of $\mathrm{pH} 5.5$. Protein and lipid recovery yields both benefited from the addition of $\mathrm{Ca}(\mathrm{OH})_{2}$ where the highest yields were recorded as $60 \%$ and $73-75 \%$ for protein and lipid recovery, respectively. Similar to that of protein concentration data, highest protein recovery was also achieved with the aid of lactic acid. Moreover, using $\mathrm{Ca}(\mathrm{OH})_{2}$ during $\mathrm{pH}$ shift processing yielded a protein fraction with lower sodium and higher calcium concentration compared to $\mathrm{NaOH}$ processing.

Protein gels recovered using $\mathrm{Ca}(\mathrm{OH})_{2}$ were harder but less cohesive compared to $\mathrm{NaOH}$ recovered proteins. Moreover, lactic acid processing decreased hardness of gels significantly compared to when hydrochloric acid was used to aid protein precipitation. Low amounts (77 or $144 \mathrm{mg} / \mathrm{kg}$ paste) of sarcoplasmic protein when incorporated into recovered protein gels or Alaska Pollock surimi did not improve gel texture (hardness or cohesiveness). On the other hand, recovered protein gels were less adversely affected from sarcoplasmic protein addition compared to Alaska Pollock surimi. When sarcoplasmic protein was concentrated and incorporated into recovered protein gels at higher concentrations $(0.5,1$ or $2.3 \%)$, more evident changes were observed in the gel texture. Incorporation of sarcoplasmic protein powder into $\mathrm{NaOH}$ processed myofibrillar protein gels showed lower textural measurements such as hardness, and cohesiveness compared to $0.5 \%$ transglutaminase addition. On the other hand, when myofibrillar 
protein was recovered using $\mathrm{Ca}(\mathrm{OH})_{2}$, sarcoplasmic protein powder addition increased textural attributes. For example, incorporation of $2.3 \%$ sarcoplasmic protein powder into calcium enhanced, myofibrillar protein gels without exogenous transglutaminase, potato starch or polyphosphates resulted in similar gel texture (hardness and cohesiveness) as gels containing the standard protein gel formula ( $1.5 \%$ starch, $0.5 \%$ transglutaminase, and $0.3 \%$ polyphosphates). Sarcoplasmic protein addition also increased whiteness of gels made from darker fleshed fish naturally. On the other hand, $\mathrm{Ca}(\mathrm{OH})_{2}$ processed myofibrillar protein gels which were whiter and lighter than $\mathrm{NaOH}$ processed protein gels, did not get whiter with the addition of sarcoplasmic protein powder.

Overall, application of different processing strategies have a significant impact on the compositional properties of recovered protein and the recovery yields. The differences in compositional and mineral contents affect functional properties of proteins during gelation and therefore impact the final gel texture and color. Protein recovery strategy should be selected according to the expected reconstructed product. Using calcium hydroxide during processing and utilizing sarcoplasmic protein as a gel additive may answer to economic feasibility while improving sustainability of natural resources. 


\section{APPENDIX}

Comparison of protein concentration and recovery yield of protein fractions using different solubilization and precipitation strategies

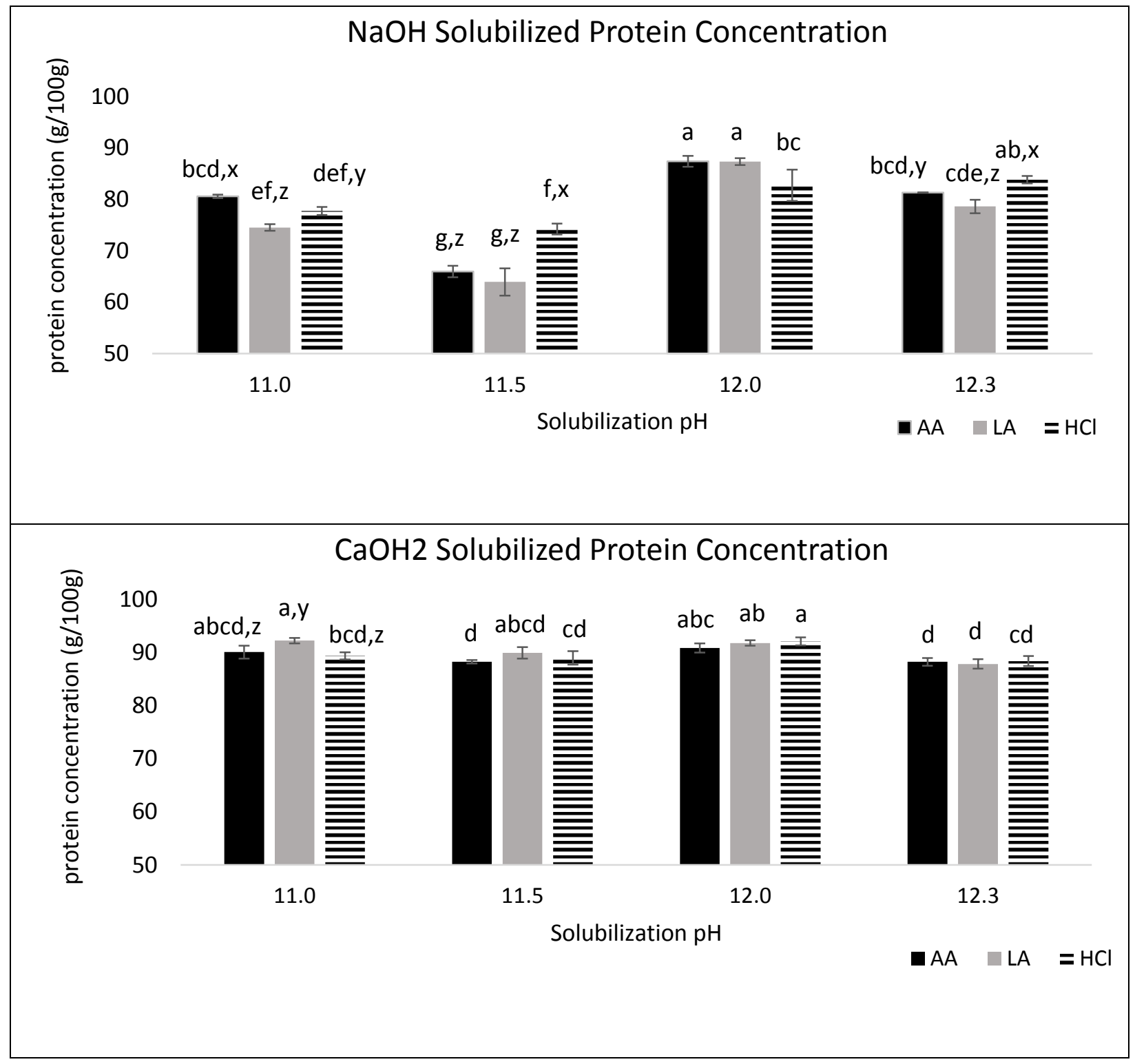

Figure 1. Protein concentrations in the recovered protein fractions using different solubilization and precipitation strategies.

a,b,c,d Mean values with different letters are significantly different (Tukey's honestly significant difference test, $\mathrm{p}<0.05)$.

${ }_{\mathrm{x}, \mathrm{y}, \mathrm{z}}$ Mean values obtained from data in the same solubilization $\mathrm{pH}$ group with different letters are significantly different (Tukey's honestly significant difference test, $\mathrm{p}<0.05$ ). 
Table 1. Proximate comporition (ash, lipid, protein) of recovered protein fractions using different processing strategies, on dry basis.

\begin{tabular}{|c|c|c|c|c|c|}
\hline \multicolumn{6}{|c|}{ Recovered Protein Fraction } \\
\hline Solubilization $\mathrm{pH}$ & Base & Acid & Ash $(\mathrm{g} / 100 \mathrm{~g})$ & Lipid (g/100g) & Protein (g/100g) \\
\hline 11.0 & $\mathrm{NaOH}$ & LA & $15.93 \pm 1.74 a b, x$ & $9.21 \pm 1.34$ efgh,y & $74.53 \pm 0.67 \mathrm{~g}, \mathrm{z}$ \\
\hline 11.0 & $\mathrm{Ca}(\mathrm{OH})_{2}$ & LA & $2.03 \pm 0.46 \mathrm{~g}, \mathrm{z}$ & $5.45 \pm 0.11 j k, z$ & $92.29 \pm 0.52 \mathrm{a}, \mathrm{v}$ \\
\hline 11.0 & $\mathrm{NaOH}$ & AA & $8.79 \pm 0.35 \mathrm{~cd}, \mathrm{y}$ & $10.27 \pm 0.60$ def,y & $80.61 \pm 0.33$ ef, $x$ \\
\hline 11.0 & $\mathrm{Ca}(\mathrm{OH})_{2}$ & $A A$ & $4.08 \pm 0.04$ ef, $z$ & $5.60 \pm 1.28 \mathrm{ijk}, \mathrm{z}$ & $90.12 \pm 1.21 a b c, w$ \\
\hline 11.0 & $\mathrm{NaOH}$ & $\mathrm{HCl}$ & $8.50 \pm 0.25 d, y$ & $13.53 \pm 0.66 \mathrm{~cd}, x$ & $78.45 \pm 0.79 \mathrm{~g}, \mathrm{y}$ \\
\hline 11.0 & $\mathrm{Ca}(\mathrm{OH})_{2}$ & $\mathrm{HCl}$ & $2.11 \pm 0.20 \mathrm{~g}, \mathrm{z}$ & $8.21 \pm 0.77 \mathrm{fghij}, \mathrm{y}$ & $89.42 \pm 0.68 a b c, w$ \\
\hline 11.5 & $\mathrm{NaOH}$ & LA & $17.04 \pm 0.53 a, w$ & $18.75 \pm 1.94 \mathrm{~b}, \mathrm{y}$ & $63.95 \pm 2.64 \mathrm{~h}, \mathrm{z}$ \\
\hline 11.5 & $\mathrm{Ca}(\mathrm{OH})_{2}$ & LA & $2.73 \pm 0.19 \mathrm{fg}, \mathrm{z}$ & $6.73 \pm 0.79$ ghijk,z & $89.97 \pm 1.09 a b c, x$ \\
\hline 11.5 & $\mathrm{NaOH}$ & AA & $10.57 \pm 0.98 c, x$ & $23.08 \pm 1.14 a, x$ & $65.96 \pm 1.12 \mathrm{~h}, \mathrm{z}$ \\
\hline 11.5 & $\mathrm{Ca}(\mathrm{OH})_{2}$ & $A A$ & $2.83 \pm 0.12$ efg, $z$ & $8.71 \pm 0.16$ fghijk,z & $88.30 \pm 0.31 b c, x$ \\
\hline 11.5 & $\mathrm{NaOH}$ & $\mathrm{HCl}$ & $9.04 \pm 0.23 \mathrm{~cd}, \mathrm{y}$ & $16.69 \pm 0.99$ bc,y & $74.23 \pm 1.07 \mathrm{~g}, \mathrm{y}$ \\
\hline 11.5 & $\mathrm{Ca}(\mathrm{OH})_{2}$ & $\mathrm{HCl}$ & $3.01 \pm 0.06$ efg, $z$ & $7.81 \pm 1.28$ fghij,z & $89.04 \pm 1.26 a b c, x$ \\
\hline 12.0 & $\mathrm{NaOH}$ & LA & $3.41 \pm 0.23$ efg,y & 8.98 \pm 0.64 fghi,y & $87.33 \pm 0.68 \mathrm{~cd}, \mathrm{y}$ \\
\hline 12.0 & $\mathrm{Ca}(\mathrm{OH})_{2}$ & LA & $4.00 \pm 0.30$ ef,y & $3.81 \pm 1.81 \mathrm{k}, \mathrm{z}$ & $91.84 \pm 0.52 a b, x$ \\
\hline 12.0 & $\mathrm{NaOH}$ & AA & $2.53 \pm 0.07 \mathrm{fg}, \mathrm{z}$ & $9.73 \pm 1.07$ efg,xy & $87.40 \pm 1.07 \mathrm{~cd}, \mathrm{y}$ \\
\hline 12.0 & $\mathrm{Ca}(\mathrm{OH})_{2}$ & AA & $2.45 \pm 0.11 \mathrm{fg}, \mathrm{z}$ & $6.56 \pm 0.85$ ghijk,yz & $90.91 \pm 0.87 a b c, x y$ \\
\hline 12.0 & $\mathrm{NaOH}$ & $\mathrm{HCl}$ & $3.51 \pm 0.26 \mathrm{efg}, \mathrm{y}$ & $13.56 \pm 3.10 \mathrm{~cd}, \mathrm{x}$ & $82.74 \pm 3.05 \mathrm{e}, \mathrm{z}$ \\
\hline 12.0 & $\mathrm{Ca}(\mathrm{OH})_{2}$ & $\mathrm{HCl}$ & $3.76 \pm 0.31 \mathrm{efg}, \mathrm{y}$ & $3.91 \pm 0.77 k, z$ & $92.14 \pm 0.76 a, x$ \\
\hline 12.3 & $\mathrm{NaOH}$ & LA & $14.95 \pm 1.72 b, x$ & $5.99 \pm 0.76$ hijk,z & $78.61 \pm 1.30 \mathrm{f}, \mathrm{z}$ \\
\hline 12.3 & $\mathrm{Ca}(\mathrm{OH})_{2}$ & LA & $4.70 \pm 0.42 \mathrm{e}, \mathrm{z}$ & $7.02 \pm 0.70$ fghijk,z & $87.89 \pm 0.91 c, w$ \\
\hline 12.3 & $\mathrm{NaOH}$ & AA & $9.39 \pm 0.32 \mathrm{~cd}, \mathrm{y}$ & $9.18 \pm 0.29$ efgh, $x$ & $81.31 \pm 0.07 \mathrm{ef}, \mathrm{y}$ \\
\hline 12.3 & $\mathrm{Ca}(\mathrm{OH})_{2}$ & AA & $4.06 \pm 0.21$ ef,z & $7.41 \pm 0.88$ fghij,xy & $88.28 \pm 0.73 b c, w$ \\
\hline 12.3 & $\mathrm{NaOH}$ & $\mathrm{HCl}$ & $3.53 \pm 0.14$ efg,z & $12.50 \pm 0.62 \mathrm{de}, \mathrm{x}$ & $83.82 \pm 0.72 \mathrm{de}, \mathrm{y}$ \\
\hline 12.3 & $\mathrm{Ca}(\mathrm{OH})_{2}$ & $\mathrm{HCl}$ & $4.63 \pm 0.37 \mathrm{e}, \mathrm{z}$ & $6.87 \pm 1.04$ fghijk,z & $88.42 \pm 0.94 b c, w$ \\
\hline
\end{tabular}

Data presented as mean $\pm^{a, b, c, d, e, f, g, \text {,hi, }, \text {,k, }}$ Mean values in a column with different letters are significantly different (Tukey's honestly significant difference test,

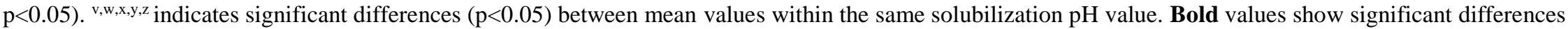
between processing bases when the solubilization $\mathrm{pH}$ and the processing acids are the same (Tukey's honestly significant difference test, $\mathrm{p}<0.05$ ). 
Table 2. Comparison of protein recovery yields extracted using different solubilization and precipitation strategies.

\begin{tabular}{|c|c|c|c|}
\hline $\mathrm{pH}$ & Base & Acid & Protein Recovery Yield (g/100g) \\
\hline 11.0 & $\mathrm{NaOH}$ & AA & $55.75 \pm 0.23 \mathrm{bc}$ \\
\hline 11.0 & $\mathrm{CaOH} 2$ & $A A$ & $44.83 \pm 0.60 \mathrm{klm}$ \\
\hline 11.0 & $\mathrm{NaOH}$ & LA & $54.47 \pm 0.49 \mathrm{~cd}$ \\
\hline 11.0 & $\mathrm{CaOH} 2$ & LA & $45.07 \pm 0.26 \mathrm{klm}$ \\
\hline 11.0 & $\mathrm{NaOH}$ & $\mathrm{HCl}$ & $52.59 \pm 0.53 \mathrm{de}$ \\
\hline 11.0 & $\mathrm{CaOH} 2$ & $\mathrm{HCl}$ & $42.00 \pm 0.32 n$ \\
\hline 11.5 & $\mathrm{NaOH}$ & AA & $50.48 \pm 0.85$ efg \\
\hline 11.5 & $\mathrm{CaOH} 2$ & AA & $46.85 \pm 0.16 \mathrm{ijkl}$ \\
\hline 11.5 & $\mathrm{NaOH}$ & LA & $46.23 \pm 1.91 \mathrm{jklm}$ \\
\hline 11.5 & $\mathrm{CaOH} 2$ & LA & $44.00 \pm 0.53 \mathrm{mn}$ \\
\hline 11.5 & $\mathrm{NaOH}$ & $\mathrm{HCl}$ & $46.00 \pm 0.66 \mathrm{jklm}$ \\
\hline 11.5 & $\mathrm{CaOH} 2$ & $\mathrm{HCl}$ & $46.35 \pm 0.66 \mathrm{jklm}$ \\
\hline 12.0 & $\mathrm{NaOH}$ & $A A$ & $48.84 \pm 0.59 \mathrm{ghi}$ \\
\hline 12.0 & $\mathrm{CaOH} 2$ & AA & $44.73 \pm 0.43 \mathrm{Im}$ \\
\hline 12.0 & $\mathrm{NaOH}$ & LA & $58.27 \pm 0.45 \mathrm{a}$ \\
\hline 12.0 & $\mathrm{CaOH} 2$ & LA & $51.40 \pm 0.29$ ef \\
\hline 12.0 & $\mathrm{NaOH}$ & $\mathrm{HCl}$ & $57.33 \pm 2.11 a b$ \\
\hline 12.0 & $\mathrm{CaOH} 2$ & $\mathrm{HCl}$ & $50.07 \pm 0.41 \mathrm{fgh}$ \\
\hline 12.3 & $\mathrm{NaOH}$ & $A A$ & $47.74 \pm 0.04$ hij \\
\hline 12.3 & $\mathrm{CaOH} 2$ & AA & $47.21 \pm 0.39 \mathrm{ijk}$ \\
\hline 12.3 & $\mathrm{NaOH}$ & LA & $45.52 \pm 0.75 \mathrm{jklm}$ \\
\hline 12.3 & $\mathrm{CaOH} 2$ & LA & $59.12 \pm 0.61 \mathrm{a}$ \\
\hline 12.3 & $\mathrm{NaOH}$ & $\mathrm{HCl}$ & $51.33 \pm 0.44$ ef \\
\hline 12.3 & $\mathrm{CaOH} 2$ & $\mathrm{HCl}$ & $52.01 \pm 0.55$ ef \\
\hline
\end{tabular}

$\overline{a, b, c, d, e, f, g, h, i, j, k, l, m, n}$ Mean values in a column with different letters are significantly different (Tukey's honestly significant difference test, $\mathrm{p}<0.05$ ). 